EYKENEGSU НАУЧНО-ТЕХНИЧЕСКИЙ И ПРОИЗВОДСТВЕННО-ЭКОНОМИЧЕСКИЙ МКУРНАA
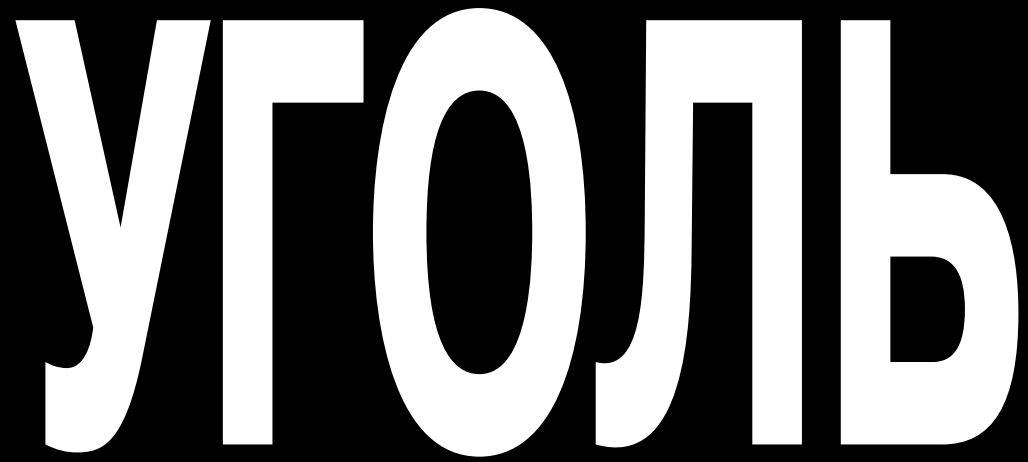

\title{
МИНИСТЕРСТВА ЭНЕРГЕТИКИ
} РОССИЙСКОЙ ФЕДЕРАЦИИ WWW.UGOLINFO.RU
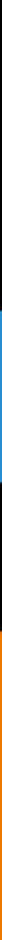

ООО НАУЧНО - ПРОИЗВОДСТВЕННОЕ ПРЕДПРИЯТИЕ

\section{«ЗАВОД МОДУЛЬНЫХ ДЕГАЗАЦИОННЫХ УСТАНОВОК»}

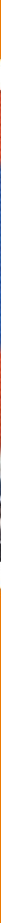


119049, Москва, Ленинский проспект, д. 6, стр. 3, офис Г-136 тел. /факс: +7 (499) 230-25-50 e-mail: ugol1925@mail.ru

www. ugolinfo. ru

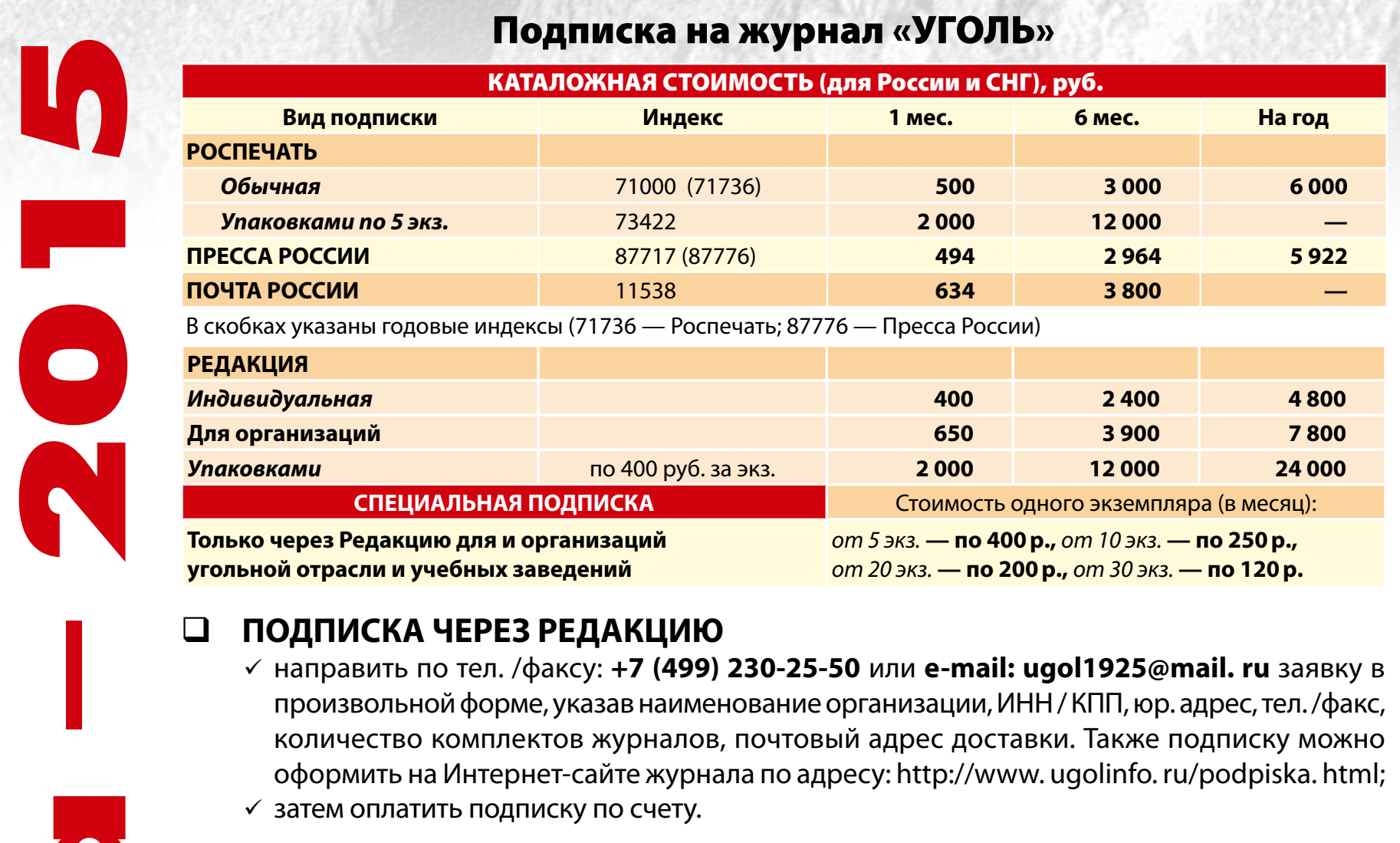

\section{ПОДПИСКА НА ПОЧТЕ (в любом почтовом отделении связи)}

\section{Тематический план журнала «УГоЛЬ» на 2015 год}

\begin{tabular}{|c|c|c|c|}
\hline $\begin{array}{c}\text { Выставки, которым посвящается выпуск журнала } \\
\text { (доп. тираж распространяется } \\
\text { среди участников выставки) }\end{array}$ & $\begin{array}{l}\text { Выпуск } \\
\text { журнала } \\
\text { «Уголь» }\end{array}$ & $\begin{array}{l}\text { Срок подачи } \\
\text { материалов } \\
\text { в редакцию }\end{array}$ & $\begin{array}{l}\text { Дата выхода } \\
\text { журнала }\end{array}$ \\
\hline Форум Неделя горняка (Москва) & № 1-2015 & 10-15 декабря & $15-20$ января \\
\hline $\begin{array}{l}\text { Форум ТЭК России в XXI веке (Москва) } \\
\text { Саммит Уголь СНГ (Москва) }\end{array}$ & № 2-2015 & 10-15 января & 15-20 февраля \\
\hline $\begin{array}{l}\text { MiningWorld Russia (Москва) } \\
\text { Итоги работы угольной отрасли за } 2014 \text { год }\end{array}$ & № 3-2015 & 10 - 15 февраля & 15-20 марта \\
\hline $\begin{array}{l}70 \text { лет Победы в Великой Отечественной войне } \\
\text { Уголь России и Майнинг (Новокузнецк) }\end{array}$ & № 4-2015 & 10-15 марта & 15-20 апреля \\
\hline $\begin{array}{l}\text { Уголь России и Майнинг (Новокузнецк) } \\
\text { Обзор Неделя горняка }\end{array}$ & № 5-2015 & $10-15$ апреля & $15-20$ мая \\
\hline $\begin{array}{l}\text { Экспо-Уголь (Кемерово) } \\
\text { Итоги работы угольной отрасли за 1-й кв. } 2015 \text { г. }\end{array}$ & № 6-2015 & $10-15$ мая & $15-20$ июня \\
\hline $\begin{array}{l}\text { Итоги MiningWorld Russia } \\
\text { Обзор Уголь СНГ }\end{array}$ & № 7-2015 & $10-15$ июня & $15-20$ июля \\
\hline $\begin{array}{l}\text { День шахтера } \\
\text { Итоги Уголь России и Майнинг }\end{array}$ & № 8-2015 & $10-15$ июля & $15-20$ августа \\
\hline $\begin{array}{l}\text { Обзор Уголь России и Майнинг } \\
\text { Итоги работы угольной отрасли за 1-е п/г. } 2015 \text { г. }\end{array}$ & № 9-2015 & $10-15$ августа & $15-20$ сентября \\
\hline $\begin{array}{l}\text { Журналу Уголь - } 90 \text { лет } \\
\text { Обзор Уголь России и Майнинг } \\
\text { Техгормет-21-й век (Санкт-Петербург) }\end{array}$ & № 10-2015 & $10-15$ сентября & 15-20 октября \\
\hline Обзор Рынок угля (Турция) & № 11-2015 & $10-15$ октября & $15-20$ ноября \\
\hline $\begin{array}{l}\text { Обзор Экспо-Уголь } \\
\text { Итоги работы угольной отрасли за } 9 \text { мес. } 2015 \text { г. }\end{array}$ & № 12-2015 & 10-15 ноября & 15-20 декабря \\
\hline
\end{tabular}


Главный редактор

ЯНОВСКий Анатолий Борисович

Заместитель министра энергетики

Российской Федерации,

доктор экон. наук

Заместитель главного редактора ТАРАЗАНОВ Игорь Геннадьевич

Генеральный директор

ООО «Редакция журнала «Уголь»

Горный инженер, член-корр. РАЭ

Редакционная коллегия

АРТЕМЬЕВ Владимир Борисович

Заместитель генерального директора,

директор по производственным операчиям

ОАО «СУЭК», доктор техн. наук

БАСКАКОВ Владимир Петрович

Генеральный директор

$O A O$ «НЦ ВостНИИ», канд. техн. наук

ВЕСЕЛОВ Александр Петрович

Генеральный директор

ФГУП «Трест «Арктикуголь», канд. техн. наук

гАлКин Владимир Алексеевич

Председатель правления ООО «НИИОГР»,

доктор техн. наук, профессор

ЕВТУШЕНКО Александр Евдокимович

Доктор техн. наук, профессор

ЗАЙДЕНВАРГ Валерий Евгеньевич

Председатель Совета директоров ИНКРУ,

доктор техн. наук, профессор

КОВАЛЕВ Владимир Анатольевич

Ректор КузГТУ, доктор техн. наук, профессор КОзОВой Геннадий Иванович

Член Совета директоров ОАО «Распадская», доктор техн. наук, профессор

КОРЧАК Андрей Владимирович

Доктор техн. наук,

профессор МГИ НИТУ МИСИС

ЛИТВИНЕНКО Владимир Стефанович

Ректор НМСУ «Горный»,

доктор техн. наук, профессор

МАЛЫШЕВ Юрий Николаевич

Президент Академии горных наук,

директор Государственного геологического

музея им. В.И. Вернадского РАН,

доктор техн. наук, академик РАН

МОСКАЛЕНКО ИГОрь ВИКТОРОВИч

Директор ОАО «УК «Кузбассразрезуголь»

МОХНАЧУК Иван Иванович

Председатель Росуглепрофа, канд. экон. наук

пОПОВ Владимир Николаевич

Доктор экон. наук, профессор

ПОТАПОВ Вадим Петрович

Зам. директора ИВТ СО РАН - директор

Кемеровского филиала, доктор техн. наук,

профессор

ПучкОВ Лев Александрович

Доктор техн. наук, чЛ.-корр. РАН

РОЖков Анатолий Алексеевич

Директор по науке и региональному

развитию ИНКРУ, Әоктор экон. наук, профессор

РЫБАК Лев Владимирович

Виче-президент ЗАО ХК «СДС»,

доктор экон. наук, профессор

суслов Виктор Иванович

Зам. директора ИЭОПП СО РАН, чЛ.-корр. РАН

ТАТАРКИН Александр Иванович

Директор Института экономики УрО РАН,

академик РАН

ХАФИЗОВ Игорь Валерьевич

Управляющий директор ОАО ХК «Якутуголь»

ЩАДОВ Владимир Михайлович

Виче-президент 3 АО ХК «СДС»,

доктор техн. наук, профессор

() «Уголь», 2014
ЕЖЕМЕСЯЧНЫЙ НАУЧНО-ТЕХНИЧЕСКИЙ ИПРОИЗВОДСТВЕННО-ЭКОНОМИЧЕСКИЙ ЖУРНАЛ

Основан в октябре 1925 года

\section{УЧРЕДИТЕЛИ}

МИНИСТЕРСТВО ЭНЕРГЕТИКИ

РОССИЙСКОЙ ФЕДЕРАЦИИ

РЕДАКЦИЯ ЖУРНАЛА «УГОЛЬ»

НОЯБРЬ

$11-2014 / 1064 /$

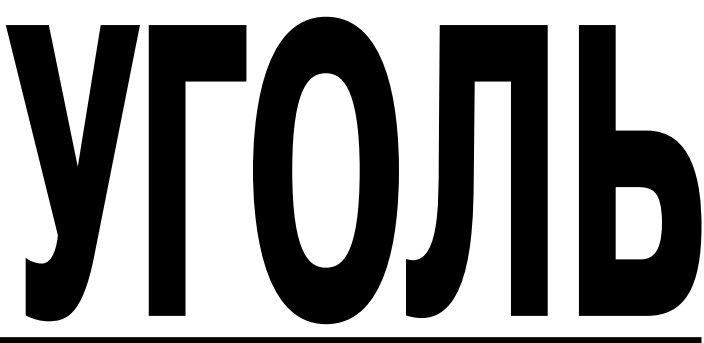

СОДЕРЖАНИЕ

\section{PEгИоны}

Санникова Н.М.

Производственные рекорды открытчиков

\section{ПОДЗЕМНЫЕ РАБОТЫ}

Клишин В.И., Опрук Г.Ю., Клишин С.В.

Механизированная отработка мощных крутых пластов подэтажами

с управляемым выпуском угля

Разумов Е.А., Сидельников А.А., Гречишкин П.В., Позолотин А.С., Венгер В.Г.

Повышение устойчивости подземных горных выработок угольных шахт, проводимых в многолетнемерзлых породах с применением сталеминеральной анкерной крепи

\section{ОТКРЫТЫЕ РАБОТЫ}

Гушинец В.А., Сидоров Р.В., Корчагина Т.В., Мезина Е.Н., Ворошилин К.С.

Опыт применения насыпных перемычек для вскрытия

и отработки рабочих горизонтов разреза ОАО «Черниговец»

16

$0 \mathrm{AO}$ «СУЭК»

Очередной производственный рекорд установлен на Назаровском разрезе

19

ИННОВАЦИИ

Стародубов А.Н., Зиновьев В.В., Дорофеев М.Ю.

0 подходе к решению задач многовариантного анализа компоновки оборудования при проектировании новых производств

НОВОСТИ ТЕХНИКИ

Corum Group

Первый шаг на польский рынок горной техники

Макаров И.С.

Комплексный сервис: всерьёз и надолго

\section{БЕЗОПАСНОСТЬ}

Юров К.М.

Комментарий к пункту 425 новых «Правил безопасности в угольных шахтах»

ЭКОНОМИКА

Попов В.Н., Грибин Ю.Г., Гаркавенко А.Н.

Повышение эффективности управления резервами роста производительности труда

на угледобывающих предприятиях

ОРГАНИЗАЦИЯ ПРОИЗВОДСТВА

Макаров А.М.

0 функционале заместителя директора предприятия по производству

Муравьев Ю.В., Фаляхов Р.Ю., Пахомов А.А., Кравчук И.Л.

Обеспечение повышения безопасности производства как важная часть функционала заместителя директора по производству угледобывающего предприятия

Лопатин С.М., Мухин Ф.К., Стецик В.А., Шестаков И.Г., Лапаева 0.А.

Обеспечение повышения эффективности производства как важная часть функционала

заместителя директора по производству угледобывающего предприятия

Брост В.Э., Машталлер В.В., Руденко А.Т., Тациенко А.Л., Шивырялкина 0.С.

Об использовании фонда оплаты труда предприятия 
ООО «РЕДАКЦИЯ ЖУРНАЛА «УГОЛЬ»

119049, г. Москва,

Ленинский проспект, д. 6, стр. 3, офис Г-136

Тел./факс: (499) 230-25-50

E-mail: ugol1925@mail.ru

E-mail:ugol@land.ru

Генеральный директор

Игорь ТАРАЗАНОВ

Ведущий редактор

Ольга ГЛИНИНА

Научный редактор

Ирина КОЛОБОВА

Менеджер

Ирина ТАРАЗАНОВА

Ведущий специалист

Валентина ВОЛКОВА

ЖУРНАЛ ЗАРЕГИСТРИРОВАН

Федеральной службой по надзору

в сфере связи и массовых коммуникаций.

Свидетельство о регистрации

средства массовой информации

ПИ № ФС77-34734 от 25.12.2008 г

ЖУРНАЛ ВКЛЮЧЕН

в Перечень ведущих рецензируемых научных журналов и изданий, в которых должны быть опубликованы основные научные результаты диссертаций на соискание ученых степеней доктора и кандидата наук, утвержденный решением ВАК Минобразования и науки РФ

ЖУРНАЛ ПРЕДСТАВЛЕН

в Интернете на вэб-сайте

\section{www.ugolinfo.ru www.ugol.info}

и на отраслевом портале «РОССИЙСКИЙ УГОЛЬ»

\section{www.rosugol.ru}

информационный партнер журнала - УГОЛЬНЫЙ ПОРТАЛ

\section{www.coal.dp.ua}

\section{НАД НОМЕРОМ РАБОТАЛИ:}

Ведущий редактор О.И. ГЛИНИНА

Научный редактор И.М. КОЛОБОВА

Корректор А.М. ЛЕЙБОВИЧ

Компьютерная верстка Н.И. БРАНДЕЛИС

Подписано в печать 06.11.2014.

Формат 60×90 1/8.

Бумага мелованная.

Печать офсетная.

Усл. печ. л. $11,5+$ обложка.

Тираж 4500 экз.

Тираж эл. версии 1600 экз.

Общий тираж 6100 экз.

\section{Отпечатано:}

РПК ООО «Центр

Инновачионных Технологий»

117218, г. Москва, ул. Кржижановского, 31

Тел.: (495) 661-46-22; (499) 277-16-02

Заказ № 13350

๑ ЖУРНАЛ «УГОЛЬ», 2014

Горев Е.В., Перов Е.В., Рыбинский А.Б., Сигитов И.В., Довженок А.С.

0 структуре функционала заместителя директора по производству

Буйницкий А.И., Горжий Р.Ю., Григорьев А.А., Журавков Р.А., Мартюшев С.А., Полевой Р.А., Полещук М.Н.

Разработка норм организации рабочего процесса «ремонт

и замена конвейерной ленты»

ВОПРОСЫ КАДРОВ

В НИТУ «МИСиС» обсудили перспективы развития горного образования в России 56

Ефимов В.И., Коновалов Д.В., Попов С.М., Федяев П.М.

Государственно-частное партнерство - путь к решению задач перевода систем

шахтного водоотлива на использование композитных материалов

ПЕРЕРАБОТКА УГЛЯ

Первое заседание MOK XVIII Международного Конгресса по обогащению угля

Задруцкий Д.В., Тер-Акопов А.Г.

Современные решения в управлении углеобогатительными фабриками

на базе новых технологий

\section{НЕДРА}

Нецветаев А.Г., Григорян А.А., Пружина Д.И.

Геодинамика кровли пласта 67 Талдинского месторождения при отработки

его комплексом КГРП

73

\section{ЭКОЛОГИЯ}

Зеньков И.В., Щадов И.М., Нефедов Б.Н.

Экологические последствия разрушения рельефа углепородных отвалов под влиянием природных факторов

РЕЦЕНЗИИ

Рафиенко В.А.

0 книге Е.А. Козловского «Избранное - 3. Минерально-сырьевые ресурсы России

(анализ, прогно3, политика)»

ЮБИЛЕИ

Клишин Владимир Иванович (к 65-летию со дня рождения)

\section{Рынокугля}

Пресс-центр компании «Бизнес-Форум»

IV Международная конференция «Рынки угля в странах Средиземного моря»

ЗА РУБЕЖОМ

Плакиткина Л.С.

Угольная промышленность Украины за период 2000-2014 годы

85

Зарубежная панорама

89

НЕКРОЛОГ

Буткин Владимир Дмитриевич (27.04.1928 - 14.10.2014 гг.)

91

Список реклам:

\begin{tabular}{|c|c|c|c|}
\hline НПП Завод МдУ & 1-я обл. & Сити Лайт Майнинг & 7 \\
\hline Журнал «Уголь» & 2-я обл. & ЧЕТРА-ПМ & 25 \\
\hline СУЭК & 3-я обл. & АМЗ ВЕНТПРОМ & 34 \\
\hline Коралайна Инжиниринг & 4-я обл. & Инжиниринг КомплекТ & 65 \\
\hline
\end{tabular}

Подписные индексы:

- Каталог «Газеты. Журналы» Роспечати

71000, 71736, 73422
— Объединенный каталог «Пресса России»

87717, 87776, $\mathbf{9 8 7 7 1 7}$

- Каталог «Почта России» - 11538 
Igor G. Tarazanov,

Director General,

Deputy Chief Editor, Mining Engineer

"Ugol" Magazine Edition LLC

Leninsky Prospekt, 6 ,

building 3, office G-136

Moscow, 119049, Russian Federation

Tel/fax: +7(499)230-2550

E-mail:ugol1925@mail.ru

www.ugolinfo.ru

\section{"UGOL" MAGAZINE IS}

a national publication and conductor of government policy in the coal mining industry of Russia. "Ugol" is the leading magazine of Russia's Coal Mining Industry. The magazine publishes industrial and social issues of coal mining companies. Furthermore, it provides economic information, statistical data, outlooks, regional reports, news about progress in mining technologies and equipment, underground and surface mining, coal processing and utilization, articles on environmental issues, miners' safety and health. Also included are experiences in other countries, short news items, mining exhibition and congress reports, official documents, notes on history of mining.

\section{COVERS}

situation and growth prospects of coal industry, operation of facilities, news of mining engineering and coal mining technology, preparation and use, labour safety and industrial safety issues, ecology, social topics, problems of restructurisation, economical information, coal market. Publishes articles from regions, chronicles, materials of mining exhibitions, conferences, congresses, official documents, history of Mining, foreign experience.

\section{SUBSCRIBERS}

are enterprises and organizations of the coal industry of Russia (coal companies, underground mines, open-pit mines, factories, concentration plants and facilities, institutes, mine rescue teams etc), various departments and establishments, organizations of related industries, municipal units of mining cities and mine villages. The Magazine is subscribed in the CIS and in more than 10 abroad countries.

\section{CAPACITY}

88-120 A4 format pages, art paper, and cover.

\section{CIRCULATION \\ 6300 copies}

\section{MONTHLY MAGAZINE, THAT DEALS WITH SCIENTIFIC, TECHNICAL, INDUSTRIAL AND ECONOMIC TOPICS}

Established in October 1925

FOUNDERS

MINISTRY OF ENERGY

THE RUSSIAN FEDERATION,

"UGOL" MAGAZINE EDITION LLC

\section{NOVEMBER}

$11-2014 / 1064 /$
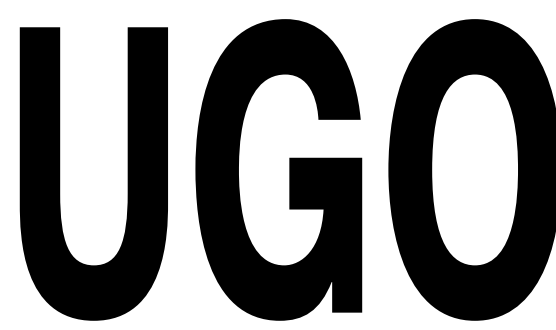

\section{REGIONS}

Sannikova N.M.

Production Records of Open-Pit Miners

UNDERGROUND MINING

Klishin V.I., Opruk G.Y., Klishin S.V.

Mechanized Mining of Thick Cragged Layers With Sub-Levels with Controlled Coal Draw

8

Razumov E.A., Sidelnikov A.A., Grechishkin P.V., Pozolotin A.S., Venger V.G.

Increasing the Stability of Underground Mine Workings of Coal Mines with Permafrost Conditions

Using Resin-Grouted Roof Bolting

SURFACE MINING

Gushinets V.A., Sidorov R.V., Korchagina T.V., Mezina E.N., Voroshilin K.S

Experience of Using the Earth-Fill Cofferdams for Opening and Mining of Producing Levels at the Open-Pit Mine of "Chernigovets"

INNOVATIONS

Starodubov A.N., Zinoviev V.V., Dorofeev M.Y.

About the Approach of Performing Multivariate Analysis of Equipment Configuration

During Designing New Productions

TECHNICAL NEWS

Makarov I.S.

Complex Service for the Long Haul

SAFETY

Yurov K.M.

Commentary to the Item 425 of New "Rules of Safety in Coal Mines"

ECONOMIC OF MINING

Popov V.N., Gribin Y.G., Garkavenko A.N.

Increasing Management Efficiency of the Labor Productivity Growth Reserves at Coal Mines

PRODUCTION SETAP

Makarov A.M.

Functions of Deputy Operational Director

Muravjov Y.V., Faliahov R.Y., Pahomov A.A., Kravchuk I.L., Galkin A.V.

Enhanced Production Security as an Important Part of Deputy Operational Director Functions

at the Coal Enterprises

Lopatin S.M., Muhin F.K., Stetsik V.A., Shestakov I.G., Lapaeva O.A.

Improving Production Efficiency as an Important Part of The Deputy Operational Director Functions

at the Coal Enterprises

Brost V.E., Mashtaller V.V., Rudenko A.T., Tatsienko A.L., Shivyrialkina 0.S.

About the Use of the Company Salary Budget

Gorev E.V., Perov E.V., Rybinskiy A.B., Rybinskiy A.B., Sigitov I.V., Dovgenok A.S.

About the Functional Structure of the Deputy Operational Director

Buynitskiy A.I., Gorjiy R.Y., Grigoriev A.A., Zhuravkov R.A., Martushev S.A., Polevoy R.A., Poleshchuk M.N.

Developing Norms for the "Conveyor Belt Repairing and Replacement" Workflow

RESURCES

Efimov V.I., Konovalov D.V., Popov S.M., Fediaev P.M.

Public-Private Partnership is the Way to Solve the Problems of Using the Composite Materials

in the Water Drainage Systems

COAL PREPARATION

Zadrutskiy D.V., Ter-Akopov A.G.

Management of Coal Preparations Plants — Modern Solutions Based on New Technologies

MINERALS

Netsvetaev A.G., Grigoryan A.A., Prugina D.I.

Geodynamics of the Coal Seam Roof 67 at the Taldinsky Deposit Through the use of the Highwall Mining ComplexECOLOGY

Zenkov I.V., Shchadov I.M., Nefedov B.N.

Environmental Effects of Relief Destruction of Coal Material Dumps Under the Influence of Natural Factors _ ABROAD

Plakitkina L.S.

Ukraine's Coal Mining Industry in the Period of 2000-2014 Years

World Mining Panorama 


\section{Производственные рекорды открытчиков}

Рассказывается о реализации программы по снижению себестоимости угля, методом повышения производительности основного оборудования, разработанной специалистами ОАО ХК «СДС-Уголь».

Ключевые слова: отгрузка горной массы, добыча угля, перевыполнениеплана, рекорд, мотивация труда, экипаж экскаватора, очистная бригада.

Контактная информация:

e-mail:nata-sannikova@yandex.ru

Третий месяц подряд коллективы предприятий с открытой добычей угля ОАО ХК «СДС-Уголь» устанавливают производтвенные рекорды. За три месяца проведено более 30 вахт повышенной нагрузки. Только за август открытчики установили четыре новых рекорда.

В период избытка угольной продукции на рынке и жесткой конкуренции между производителями угля, в более выгодной ситуации оказываются компании, уменьшающие себестоимость производства, соответственно снижая стоимость собственной продукции в соответствии с требованиями рынка. Одним из факторов в снижении себестоимости является повышение производительности основного оборудования. Главным условием выполнения поставленных задач является заинтересованность непос- редственного оператора оборудования в достижении максимальных объемов и повышении производительности.

Специалистами компании «СДС-Уголь» была разработана программа мотивации, которая охватывает все специальности - от рабочего до директора предприятия. Одно из ее направлений — проведение суток повышенной нагрузки.

«Сегодня нам необходимо заинтересовать наших работников в достижении максимальных объемов производительности, - говорит Игорь Балашов, начальник департамента открытых горных работ ОАО ХК «СДСУголь». - Поэтомумы проводим дни повышенной нагрузки, а горняков, справившихся с поставленными задачами, поошряем денежными премиями. Чтобы акцентировать внимание всех сотрудников на важность события, данные о результатах рекордных суток выводятся в онлайн режиме на информационных табло на всех предприятиях компании».

Дни повышенной нагрузки проводятся как на предприятиях с открытой добычей, так и на шахтах компании. Проведение суток высокопроизводительного труда позволяет оценить возможности оборудования, при создании оптимальных условий работы. Обобщенные данные, полученные по результатам проведения дней повышенной нагрузки, позволяют рационально планировать нагрузку на экскаваторный парк предприятий компании не только на месяц, но и нагод.

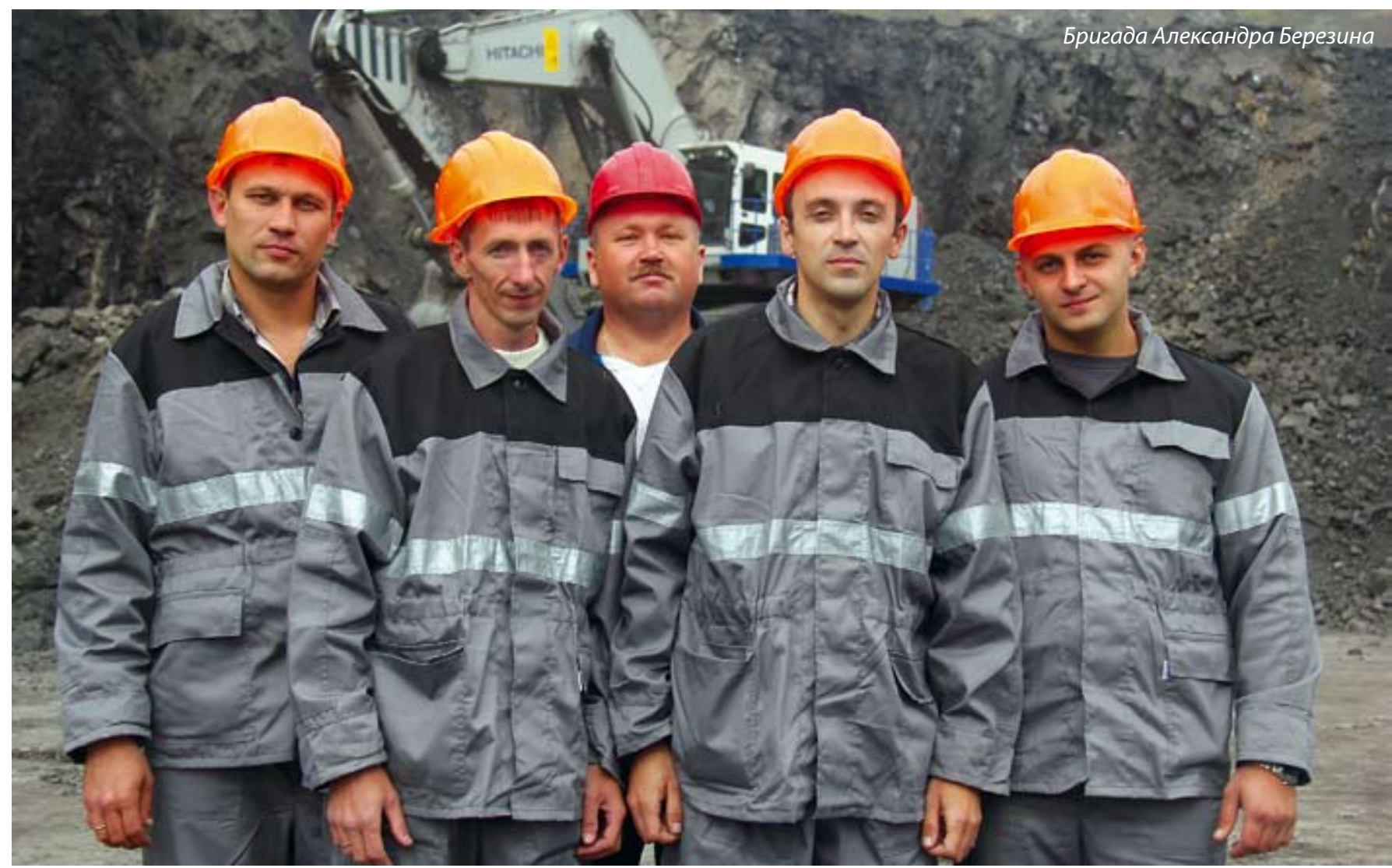


Несомненно, что проведение рекордных суток для достижения высоких производственных показателей возможно только благодаря слаженным действиям коллектива и тщательной предварительной подготовки. Поэтому на всех предприятиях с открытой добычей создаются все необходимые условия для работы техники с максимальной производительностью.

Необходимо отметить отличные результаты, достигнутые бригадами экскаваторов. Так в августе бригада Александра Гринева (экскаватор P\&H-2800 №50) ОАО «Черниговец» при нормативной суточной нагрузке экскаватора - 31,3 тыс. куб. м, в день повышенный нагрузки вскрыша экскаватора отгрузила 54,1 тыс. куб. м горной массы, т.е. 173 \% плана. Бригада Олега Милорадова (экскаватора Komatsu PC-5500 №55) ОАО «Черниговец» отгрузила 38,5 тыс. куб. м за сутки, что на 13,5 тыс. куб. м больше нормы или $154 \%$ выполнения норматива.

Бригада под руководством Александра Березина «Прокопьевского угольного разреза» на гидравлическом экскаваторе Hitachi EX-1200 №1300 за сутки отгрузила 11,9 тыс. куб. м горной массы, что составило 198 \% плановой нагрузки.

На разрезе «Восточный» с повышенными обязательствами справилась бригада Вячеслава Санникова Hitachi EX-3600 №56, отгрузив фактически 30,3 тыс. куб. м вскрыши, выполнение среднесуточного норматива - $151 \%$.

Бригада Александра Лапушкина Hitachi EX-2500 №1165 разреза «Сибэнергоуголь» в октябре выполнила норматив на 179\%, отгрузив 26,9 тыс. куб. м горной массы. Еще один коллектив разреза бригада Виталия Русанова Liebher R-984 №28076 в августе справился с заданием, отгрузив 15 тыс. куб. м, выполнив план на $238 \%$.

На сегодняшний день по итогам проведения суток высокопроизводительного труда лучших результатов достигли бригады разреза «Киселевский». Впечатляющего перевыполнения плана в августе смогли добиться экипажи экскаваторов ЭКГ 10 №13 - 20,9 тыс. куб. м (286\%) и ЭШ 13/50 №14 - 24,9 тыс.

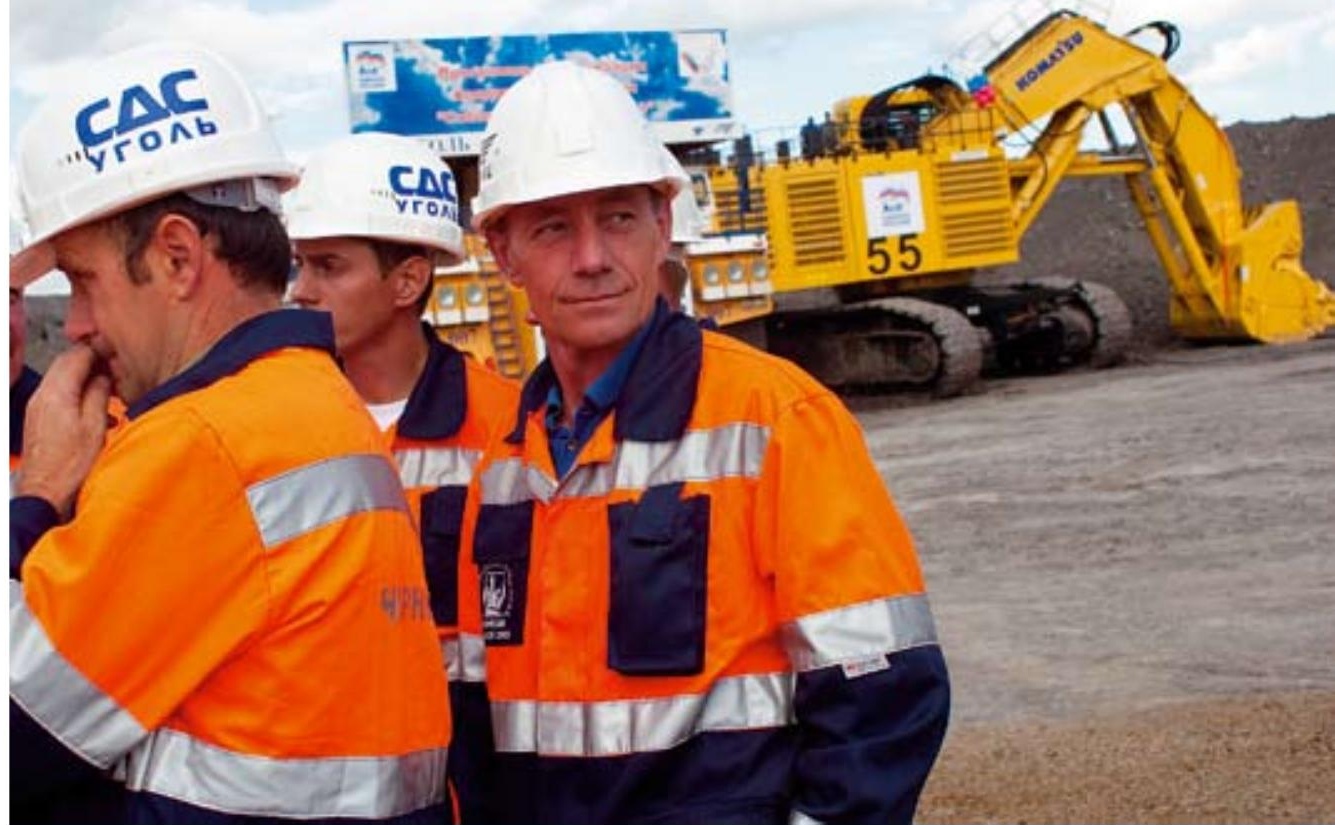

Бригадир Олег Милорадов

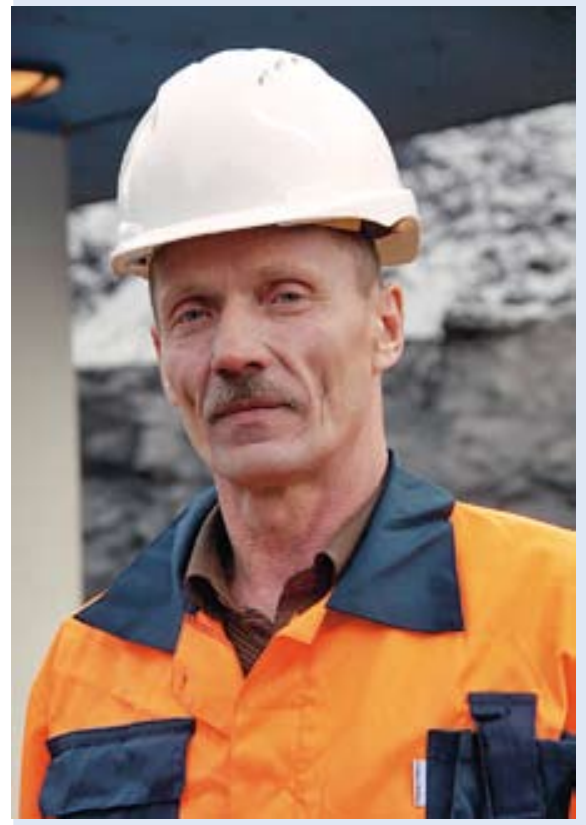

Бригадир Александр Гринев

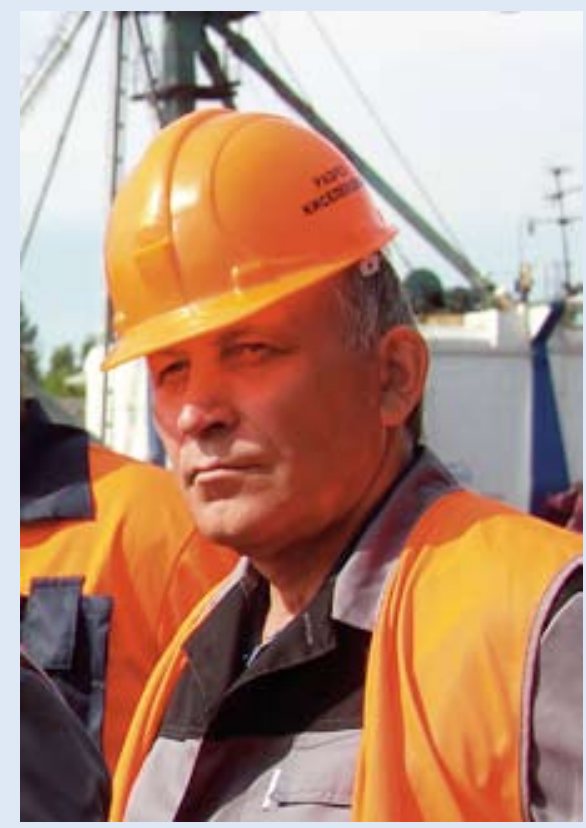

Бригадир Владимир Пластун

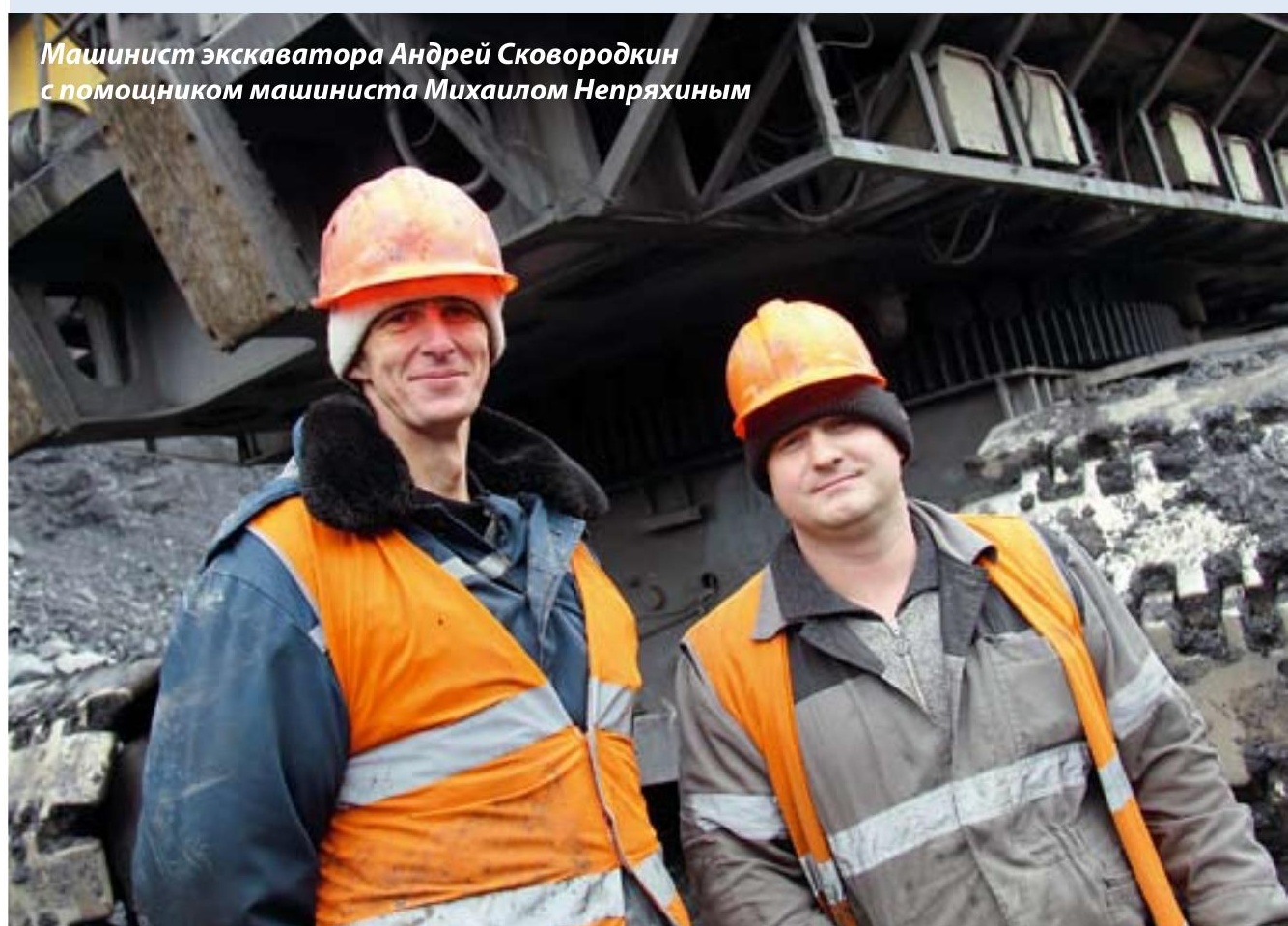


куб. м (323\% к нормативу), под руководством бригадиров Вячеслава Овсянникова и Владимира Пластуна. А в октябре значительных результатов добились бригады экскаваторов ЭКГ 10 №2008 Андрея Сковородкина и ЭШ 13/50 №197 Сергея Колоса, отгрузившие 18,3 и 22,3 тыс. куб. м горной массы, что составляет $158 \%$ и 201 \% плана. «Уверен, что регулярное проведение подобных дней повышенной нагрузки нам очень на руку, - считает Андрей Сковородкин, машинист ЭКГ 10. - Конечно мы к рекордным суткам готовимся. Нам важна не только мотивация - награждение денежными премиями за отличный труд всегда радует. Мы, как непосредственные исполнители знаем на что способна наша техника. А еше хочется показать хорошие результаты и доказать, в очередной раз, самим себе и коллективу, что мы умеем и любим работать».

Вахта суточных рекордов будет продолжаться и не только на предприятиях с открытой добычей угля компании «СДС-Уголь». В скором времени к ней присоединяться и шахтеры «Листвяжной» и «Южной». Горняки поймали производственный кураж, и останавливаться на достигнутом не собираются.

\section{Шахтеры «Листвяжной» — большие объемы,}

\section{новые достижения}

Очистная бригада Евгения Дорохина ООО «Шахта Листвяжная» (участок №4, начальник (ергей Пешков) по итогам сентября 2014 г. установила рекорд шахты по добыче с пласта "Грамотеинский-II", выдав на-гора 275 тыс. $m$ угля. Этоm результат является наивысиим за всю историю предприятия.

Производственное достижение трудовой коллектив установил в лаве № 1315. Бригада Евгения Дорохина - гордость предприятия заслуженный очистной коллектив «Листвяжной», один из старейших на предприятии. Более трёх десятков лет трудиться на шахте Евгений Александрович, половину из них руководит очистной бригадой. «Коллектив у нас крепкий, спаянный, - говорит полный кавалер знака «Шахтерская слава», «Почетный шахтер РФ» Евгений Александрович Дорохин. - Все в ответе друг за друга, работаем в одной упряжке. И наше сентябрьское достижение - заслуга каждого, кто трудится на шахте. Мы звенья одной чепи: очистники, проходчики и вспомогательные участки. А с таким коллективом, хорошей лавой и современной техникой можно двигаться только вперед — к новым трудовым победам!».

К слову сказать, рекордные нагрузки взяли на себя не только очистные коллективы. Так специалисты участка монтаж-демонтаж оборудования (МДО) под руководством Виктора Сарапулова в сентябре выполнили перемонтаж

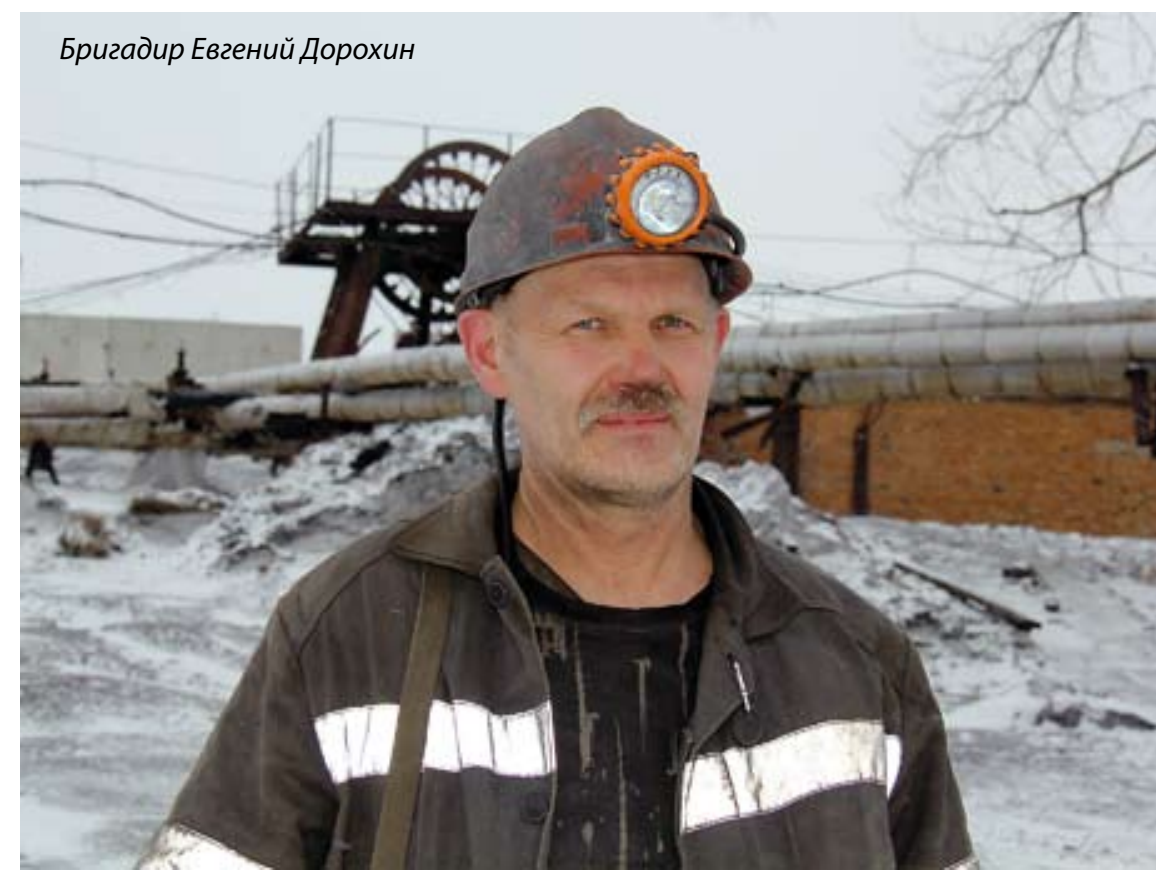

более 3 км транспортных линий по пласту «Сычевский-IV». B середине октября ввели в строй еще 4 км ленточных конвейеров по пласту «Грамотеинский-ІІ».

Заявленныебольшиеобъемыдобычи-этостабильноеповышение производительности труда на всех «фронтах» предприятия. Уже в начале октября благодаря стабильной работе коллектива шахтеры «Листвяжной» перешагнули планку добычи года предыдущего (в 2013 г. добыто 4,27 млн т), выдав на-гора 4,4 млн т угля. В целом за 2014 год горняки обязуются Выдать 5,8 млн т угля и продолжить славную традицию шахтерских рекордов.

Наталья САННИКОВА, ведущий специалист по ССО ОАО ХК «СДС-Уголь» 


\section{PROLIEHT 0 of}

СВЕТОДИОДНЫЕ ПРОЖЕКТОРЫ для ГОРНОЙ, КАРЬЕРНОЙ И СПЕЦТЕХНИКИ
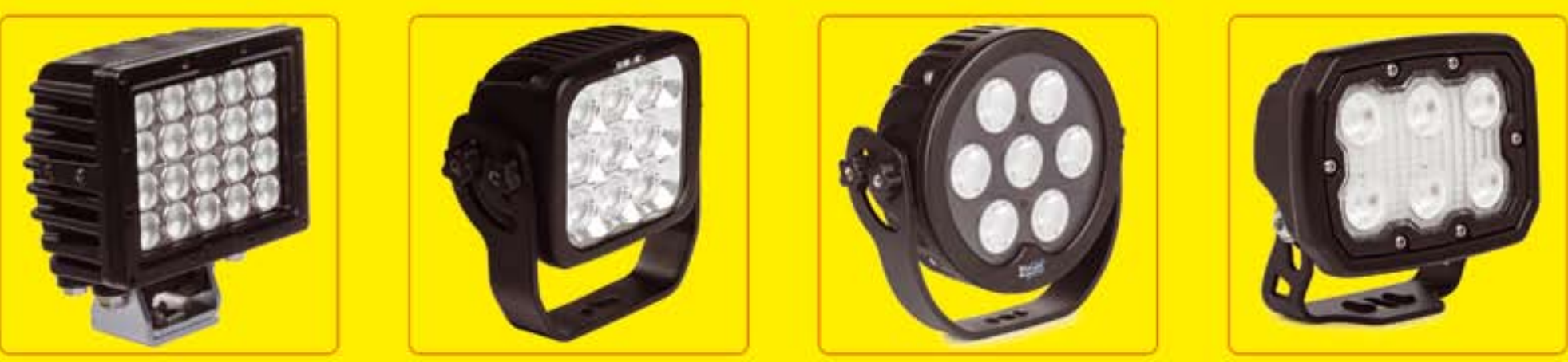

- огромная светоотдача позволит более безопасно и эффективно проводить работы

- срок службы светодиодов до 50000 часов позволит не останавливать работу техники для замены освещения

- благодаря высокой виброустойчивости и пыле-влагозащищенности класса IP-69K

светодиодные прожекторы PROLIGHT идеальны для эксплуатации в различных дорожных и погодных условиях.

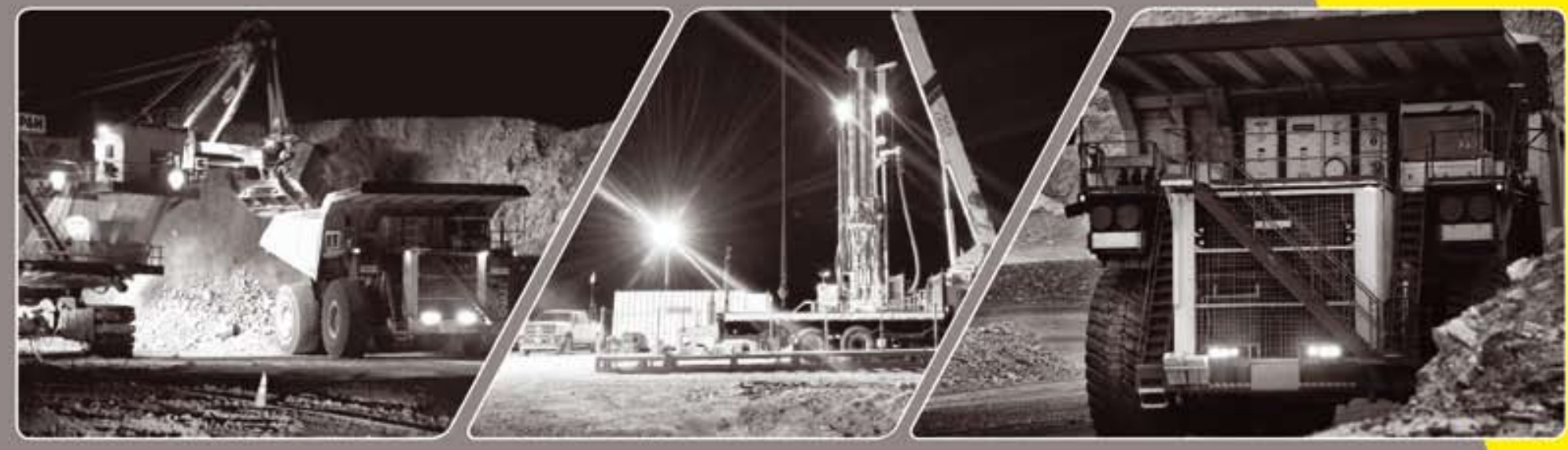

Серия PIT MASTER - идеальное решение для карьерных экскаваторов ЭКГ и ЭШ

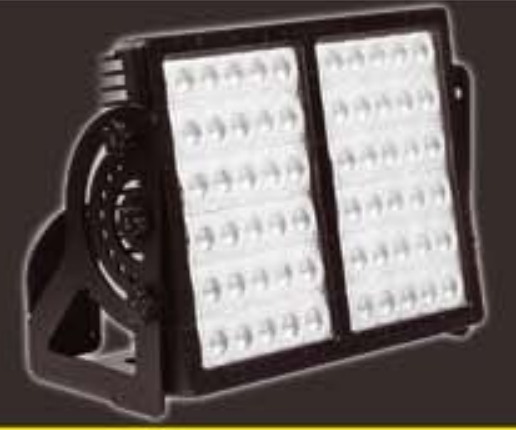

Светодиодные прожекторы PIT MASTER

были разработаны для замещения

металлогалогенных ламп и натриевых ламп высокого давления.

В серии PIT MASTER предусмотрена возможность подключения к сети переменного тока напряжением 220V.

ОФИЦИАЛЬНЫЙ ДИСТРИБЬЮТОР В РОССИИ И СТРАНАХ СНГ

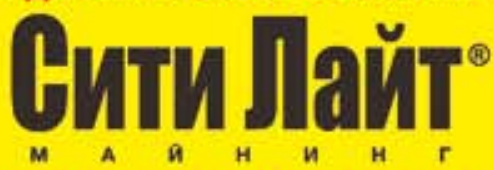

$\sum_{\Sigma}^{\varsigma}$ ПРИГЛАШАЕМ К СОТРУДНИЧЕСТВУ! 8-800-250-77-99

Новинка! МОЩНЫЕ светодиодные маяки

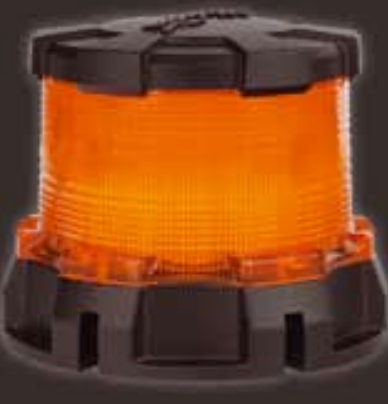

E-mail: informininglight.ru WWW.MININGLIGHT.RU 


\section{Механизированная отработка мощных крутых пластов}

\section{подэтажами с управляемым выпуском угля}

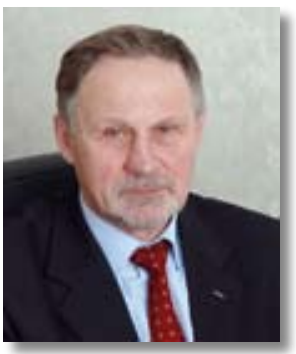

КлИшИн

Владимир Иванович

Директор Института угля

СО РАН, чЛ. -Корр. РАН

2. Кемерово, Россия,

e-mail:klishinvi@icc.kemsc.ru

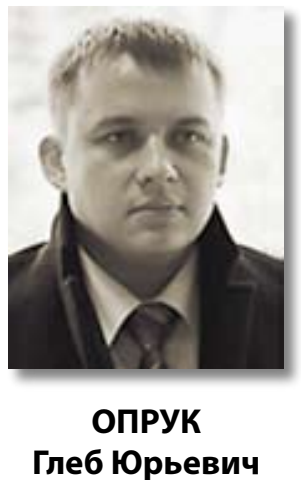

Ведущий технолог

Института угля СО РАН

2. Кемерово, Россия

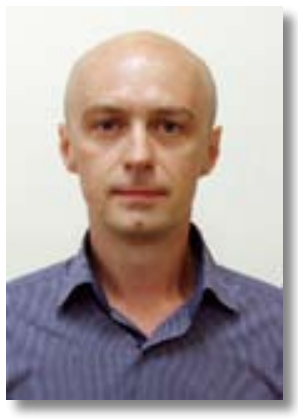

клИшин

Сергей Владимирович

Старший научный сотрудник

Института горного дела им. Н.А. Чинакала СО РАН, канд. техн. наук

2. Новосибирск, Россия, e-mail:sv.klishin@gmail.com
Предложено развитие технологии подэтажной разработки мощных крутых угольных пластов на основе управляемого выпуска угля на конвейер, расположенный между спаренными секциями механизированных крепей, через ограждения которых также ведут выпуск, что обеспечивает большую полноту выемки угля и безопасные условия отработки. Выполнено физическое моделирование на специально разработанном стенде и численное моделирования процессов гравитационного движения гранулированных материалов методом дискретных элементов.

Ключевые слова: система разработки, мощный крутой пласт, механизированная крепь, подэтажная выемка, площадной выпуск, моделирование на стенде, метод дискретных элементов.

В России мощные крутые пласты залегают в Кузнецком угольном бассейне и на Апсатском каменноугольном месторождении в Читинской области. Запасы их составляют приблизительно 1,184 млрд т. В настоящее время активно ведется разработка Апсатского месторождения (запасы 0,5 млрд тугля дефицитных марок), которое является единственным новым месторождением на трассе БАМ. В странах ближнего и дальнего зарубежья такие пласты сосредоточены на: месторождениях Закавказья (Ткварчельское и Шаорское); Средней Азии (Шаргуньское), а также Польши, Китая, Болгарии, Индии, Турции.

Разнообразие условий залегания мощных угольных крутых пластов вызвало необходимость применения различных систем разработки, наиболее предпочтительными из которых являются системы подэтажного обрушения, использующие гравитационный выпуск угля. В 1970-хгг. спроектированы и изготовлены три экспериментальных образца комплекса подэтажной выемки («крепь-штрек») ПКК Киселевского машиностроительного завода им. Черных, КПО института Сибгормаш, и АПВ института КузНИУИ [1]. Комплексы были предназначены для разработки мощных крутопадающих пластов с углом залегания 45-90 и мощностью 6-10 м. Выполненные шахтные испытания трех вариантов комплексов «крепь-штрек» в условиях шахт Прокопьевско-Киселевского района свидетельствуют об их эффективности.

Результаты промышленных испытаний показали возможность применения и перспективность такой системы для разработки мощных крутых пластов, обеспечивающей механизацию процесса добычи угля и безопасность работ в забое. При работе с выпуском межэтажной толщи угля значительно повысилась нагрузка на забой. Однако, наряду суспешными опытно-промышленными испытаниями комплексов, был известен и ряд трудностей связанных с процессом управления полнотой выпуска угля.

В развитие технологии подэтажной выемки предложена инновационная технологическая схема подэтажной механизированной разработки мощных крутых пластов с управляемым выпуском угля (рис. 1).

В предложенной системе подэтажной выемки пласт рассекается по простиранию на всю длину отрабатываемого блока подэтажными штреками, соединенными между собой углеспускными и ходовыми скатами. Между подэтажными штреками также по простиранию проходят промежуточные компенсационные штреки, из которых можно производить операции по разупрочнению угольного целика, расположенного между подэтажными штреками. Наиболее сложной операцией при применении этой технологии является безопасный и эффективный выпуск угля из разрушенного целика на подэтажный штрек.

В наше время идея подэтажной выемки угля была использована авторской группой польской фирмы «GEOTECH» на крутых пластах в условиях шахты «Казимеш-Юлеуш», а сам способ назван подберковой системой [2]. Для добычи угля применяется механизированный комплекс BMV-10 (Словения) (рис. 2, а).

Эта система разработки успешно зарекомендовала себя на пласте мощностью 20 м с углом залегания $45^{\circ}$. Однако при добыче сохранились большие потери угля и опасность его самовозгорания. 

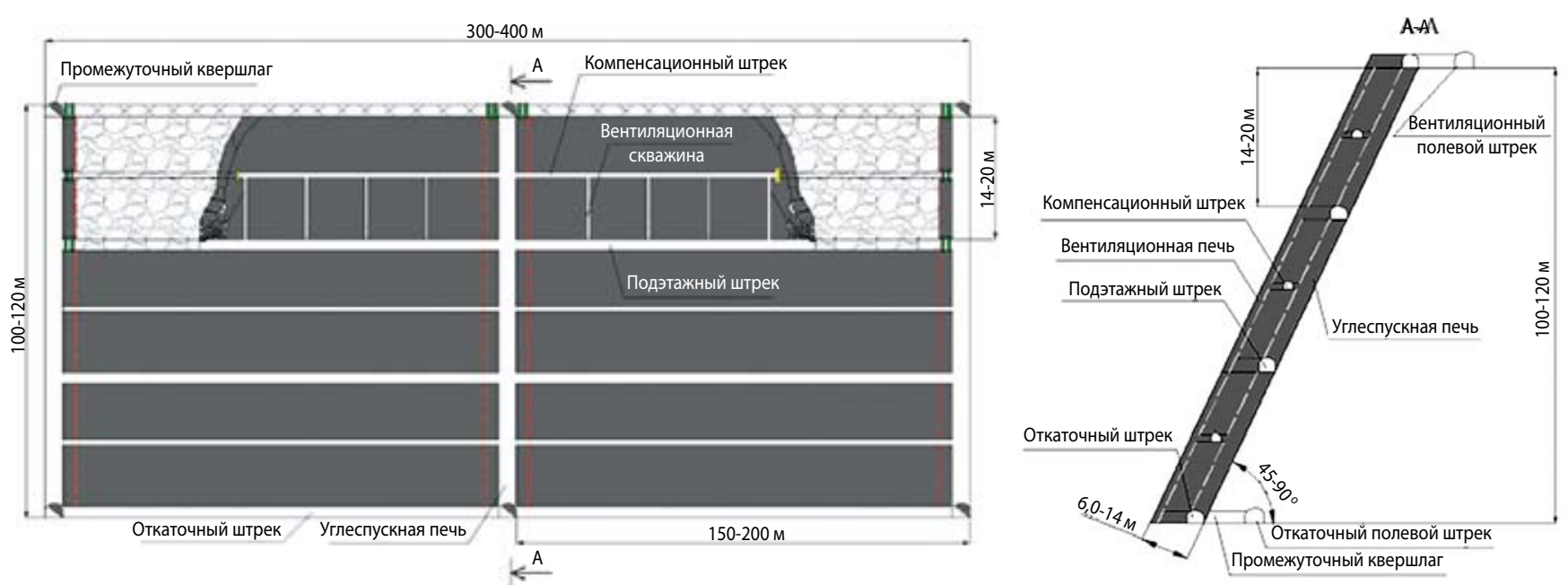

Puс. 1. Система разработки мощного крутого пласта подэтажными штреками с выпуском угля

Для управления процессом выпуска угля и полноты его извлечения в системе подэтажного обрушения предложен механизированный комплекс подэтажного выпуска КПВ-1 (см. рис. 2, б), обеспечивающий управляемый площадной выпуск угля из межэтажного целика на подэтажный штрек [3]. Область применения комплекса - пласты мощностью 6-14 м. с углом залегания 45-90. Комплекс КПВ-1 включает в себя две секции оградительно-поддерживающего типа. Каждая секция состоит из ограждения шарнирно связанного с рамой, основания, гидростоек, верхняка, шарнирно закрепленного на перекрытии, гидродомкрата передвижения, установленного на основании. В ограждении каждой секции крепи распложено выпускное окно для выпуска самообрушающегося угля из межслоевой толщи в виде желоба с бортами, расширяющимися в сторону разгрузки и жестко закрепленного бортами к несущим балкам перекрытия, и днищем, опертым на основание и покрытым антифрикционным материалом, на котором смонтирован плунжерный питатель, выполненный в виде жесткой плиты и имеющий для нее возвратно-поступательное перемещение, с помощью привода в виде гидроцилиндра. Ограждения секций крепи также снабжены откидными щитами. Между основаниями секций на почве штрека установлен став скребкового перегружателя. Секции связаны со ставом перегружателя гидроцилиндром подачи.

Проведены сравнительные лабораторные исследования выпуска угля на конвейер, расположенный между ограж- дениями секций механизированной крепи (рuc. 3, 4), для конструкции механизированного комплекса BMV-10 (см. puc. 1, a), применяемого в Польше, и предлагаемого комплекса подэтажной выемки КПВ-1 (см. рис. 1, б).

В первом варианте вследствие ограниченного потока угля по мощности пласта в движение вовлекается покрывающая порода, постепенно заполняя освобождаемое углем место и образовывая воронку внедрения - клин. Это приводит к значительным потерям выпускаемого угля (см. рис. 3). Во втором варианте при одновременном выпуске угля на конвейер между секциями крепи и через питатели в окнах крепи резко увеличивается зона выпуска, и контактная граница «уголь-порода» опускается горизонтально, то есть обеспечивается управляемый площадный выпуск угля с минимальными потерями (см. рис. 4).

Исследования конструкции питателя показали, что при возвратно-поступательном движении плоского питателя выпуск угля и покрывающих пород начинается с забойной стороны, образуя конус выпуска, заполняемого породой, при этом значительная часть угля в виде застойной зоны остается в завальной стороне (рис. $5, a$ ).

При возвратно-поступательном движении питателя в виде треугольного конуса создается выраженная параболическая асимметрия выпуска, когда зона потока со стороны верхняка крепи на уровне выпускного окна выпрямляется, а в завальной части остается узкая застойная зона из угля (см. рис. 5, 6). Однако возвратно-поступательноедвижение наклонной час-
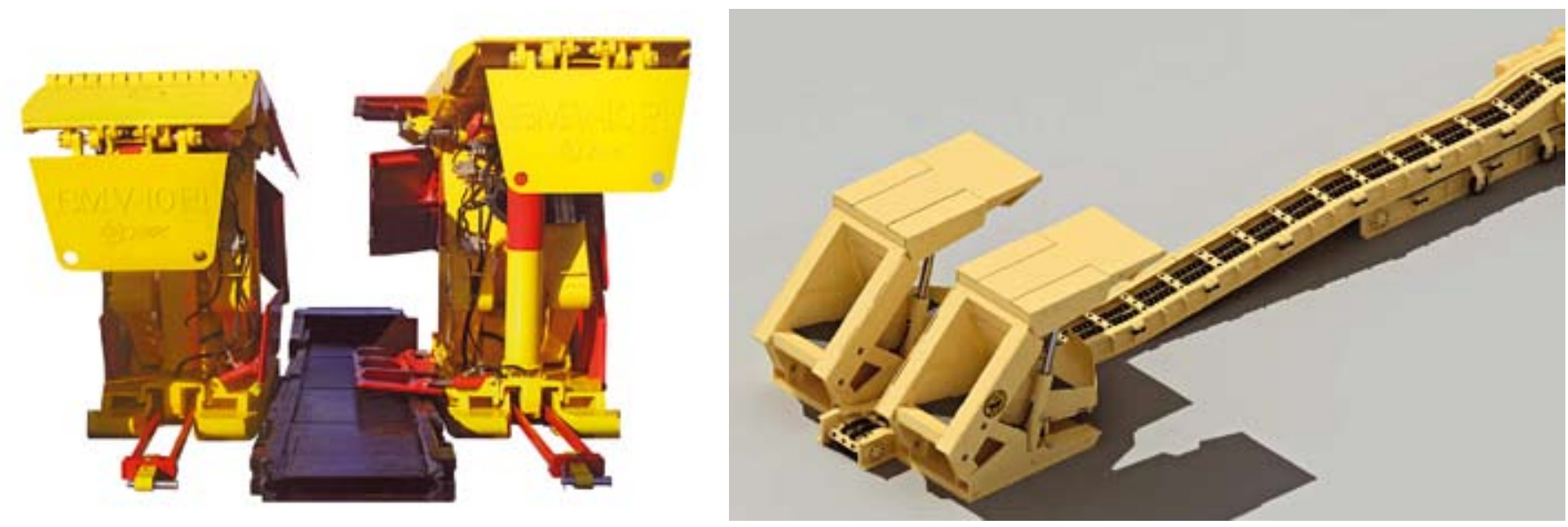

Puc. 2. Механизированные комплексы для отработки мощного крутого пласта подэтажами с выпуском: а - механизированный комплекс КПВ-1(Институт угля СО РАН); б - механизированный комплекс BMV-10(Словения). 

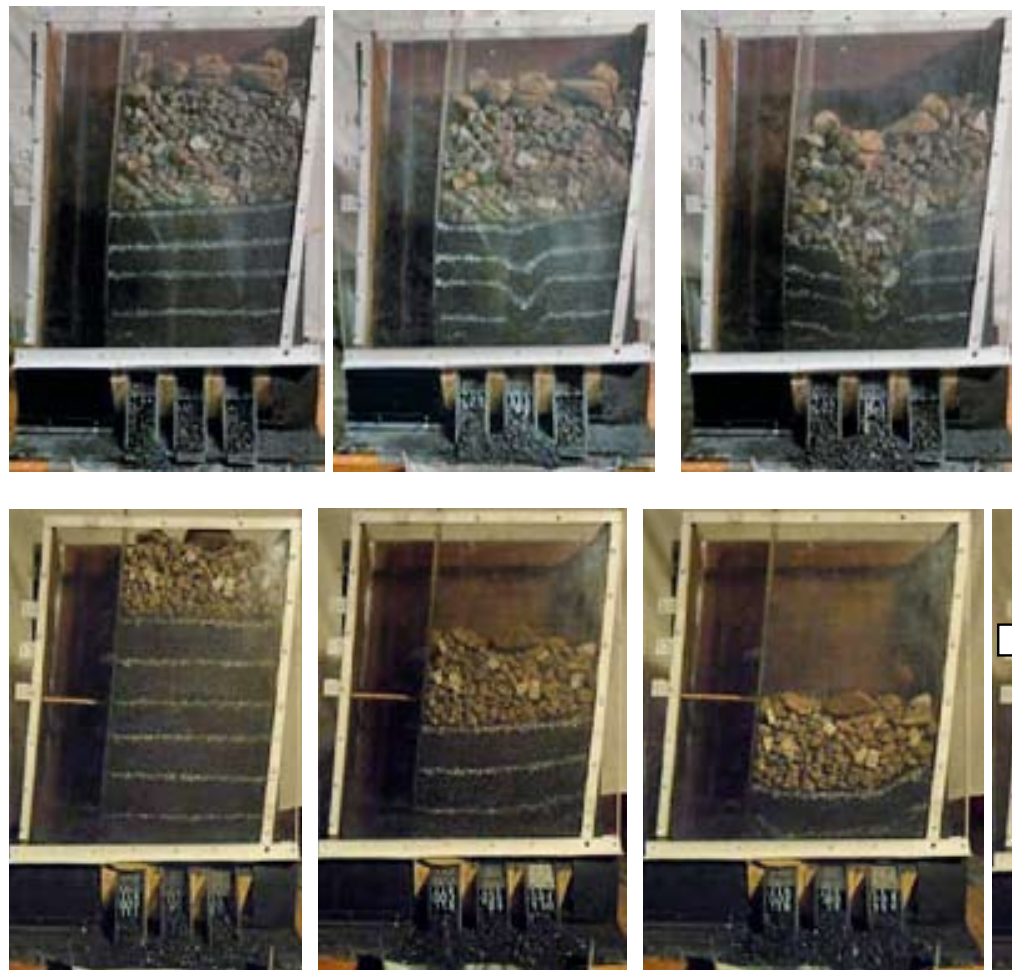

a
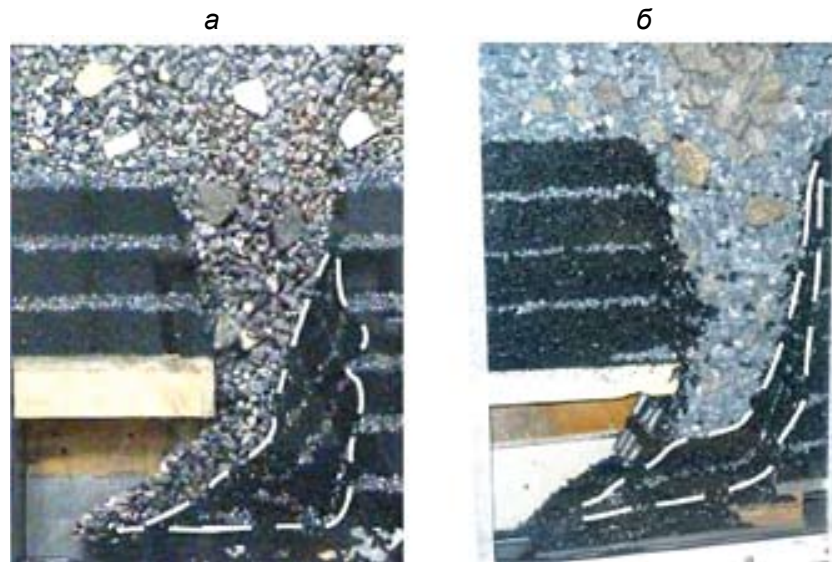

ти этого питателя, контактирующей с массивом, приводит к образованию зоны выпуска, близкой к симметричной. При этом смещение зоны потока происходит сначала с завальной стороны, что позволяет осуществить разворот потока угля на питателе и создать подпор из породной подушки (см. puc. 5, в). В этом случае угол наклона зоны потока с обеих сторон увеличивается до $85^{\circ}$, образуя вертикальные стенки, а выпускное окно работает как свободное отверстие, что исключает образование застойной зоны из угля на питателе. Таким образом, за счет этого увеличивается полнота выемки угля по простиранию пласта, а шаг передвижки крепи исходя из конструкции может достигать 2 м.

На базе физического моделирования разработана математическая модель для численного моделирования процессов гравитационногодвижения гранулированныхматериалов со сцеплением в трехмерной постановке методом дискретных элементов [4, 5]. На рис. 6, б-е представлены стадии течения в различные моменты времени в случае, когда выпускные отверстия были открыты одновременно в начальный момент времени. Смещение материалов демонстрируется чередованием темных и светлых полос. Кинематическая картина качественно повторяет картину схожих экспериментов, проведенных в лабораторных условиях. Расстояние между пускных отверстий. кные отверстия.

\section{ВЫВОдЫ}
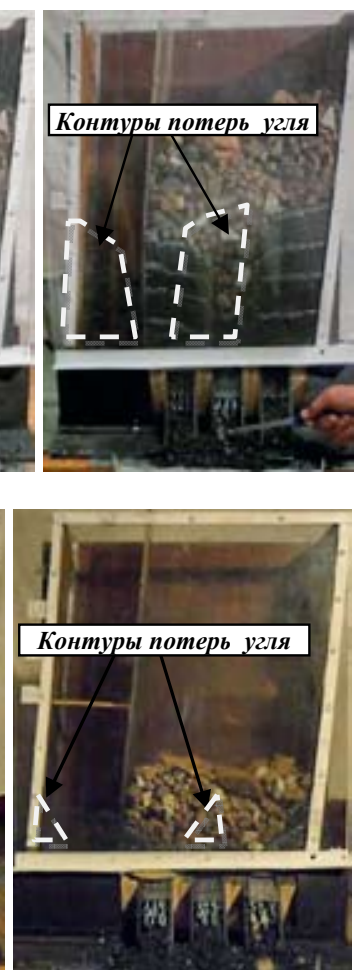

Рис. 3. Моделирование выпуска угля на конвейер через чентральное окно между секциями крепи (механизированный комплекс BMV-10)

Рис. 4. Моделирование управляемого площадного выпуска (механизированный комплекс КПВ1)

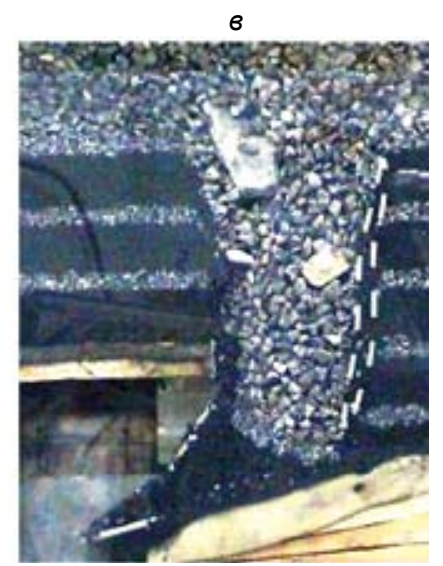

Puc. 5. Влияние muna питателя на показатели извлечения угля: $a$ - плоский питатель на почве пласта;

б-клиновый питатель; в-клиновый питатель с движущейся верхней частью

выпускными отверстиями обеспечивает весьма большую ширину потока, не разделяя его на отдельные.

Вертикальная компонента вектора скорости (рис. 7) растет равномерно, что обусловлено наличием трех вы-

При регулируемом выпуске достигается относительная стабилизация скорости прохождения потока через выпус-

Таким образом, усовершенствованная технология добычи угля на мощных крутых пластах суправляемым выпуском позволит в недалеком будущем заменить традиционные трудоемкие системы разработки. Преимущества предлагаемой технологии заключаются в значительном сокращении объемов подготовительных работ, капитальных и эксплуатационных затрат, а также возможности разработки пластов в сложных горно-геологических условиях.

Установлено, что полнота выемки, управляемый площадный выпуск угля и безопасные условия работы в технологии разработки мощных крутых пластов подэтажным обрушением обеспечиваются системой выпуска угля на конвейер, расположенный между спаренными секциями 
a
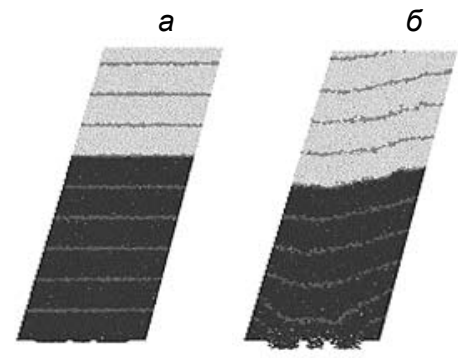

6
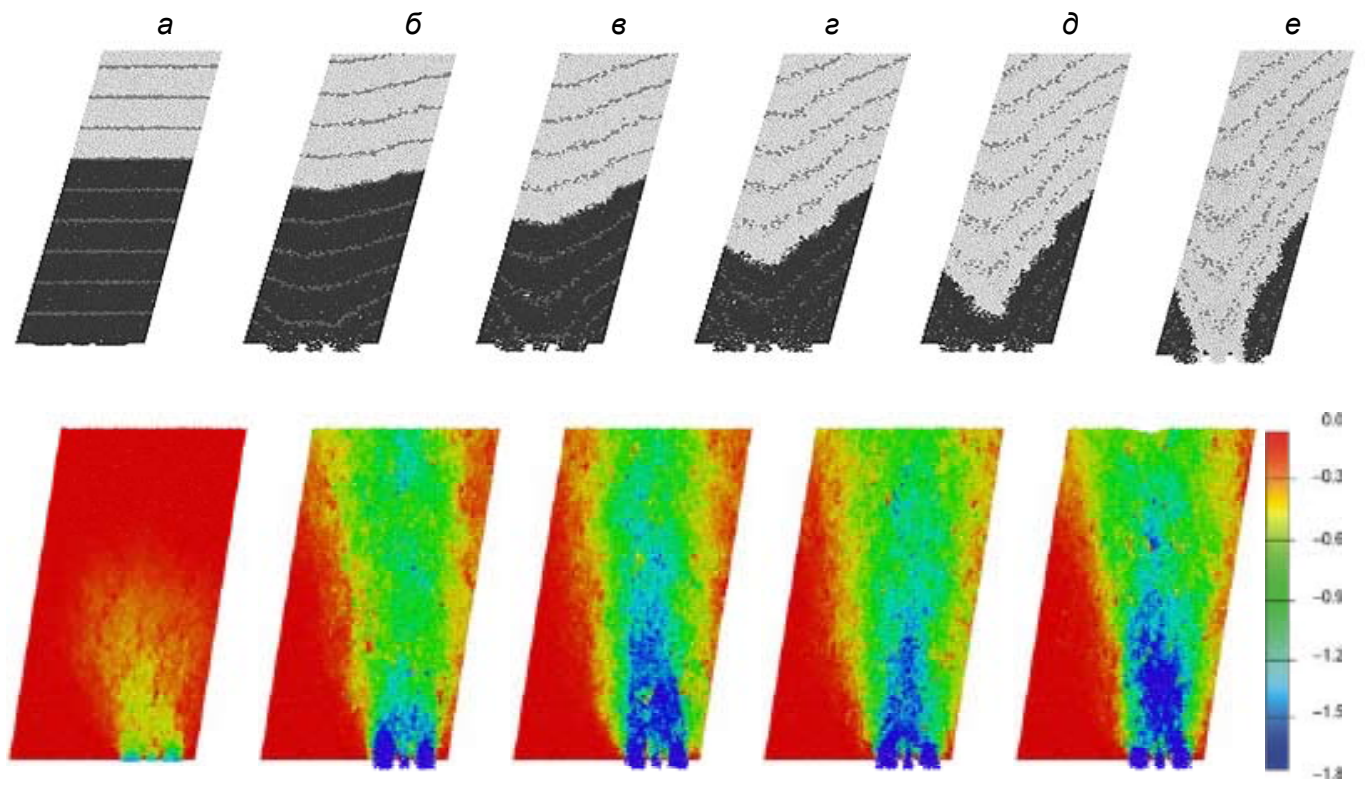

Рис. 6. Кинематическая картина выпуска горной породы при трех одновременно открытых выпускных окнах

Рис. 7. Поле

скоростей, $\mathrm{M} / \mathrm{C}$ механизированной крепи, и через окна в ограждении крепи регулируемыми по производительности питателями. При возвратно-поступательном движении плиты питателя, расположенного в секции крепи под углом в сторону разгрузки угля, достигается образование максимальной зоны выпуска за счет разворота потока угля на питателе, что позволяет обеспечить полноту выемки по простиранию пласта.

Механизированный комплекс оборудования для подэтажной выемки позволит увеличить нагрузку на пласт, полноту выемки угля и снизить опасность его самовозгорания. Возможность механизации горных работ на крутом падении позволит значительно сократить долю ручного труда, увеличить производительность и повысить безопасность ведения горных работ.

\section{Список литературы}

1. Клишин В.И., Клишин С. В., Опрук Г. Ю. Моделирование процесса выпуска угля при механизированной отработ- ке мощных крутопадающих угольных пластов // ФТПРПИ. 2013. №6. С. 105-117.

2. Stanislaw Gajos. Experience and practical aspects of utilizing a shrinkage metod of extraction at «Kazimierz-Juliusz» coal mine in Sosnowiec. International mining forum, New technologies in underground mining, Safety in mines. CracowSzczyrk-Wieliczka, Poland, 2004.

3. Разработка мощных пластов механизированными крепями с регулируемым выпуском угля / В.И. Клишин, Ю.С. Фокин, Д.И. Кокоулин и др. Новосибирск: Наука, 2007.

4. Клишин В.И., Клишин С. В. Исследования процесса выпуска угля при отработке мощных пологих и крутых угольных пластов // ФТПРПИ. 2010. №2. С. 69-81.

5. Перспективные технические решения отработки мощных пологих угольных пластов с выпуском / В.И. Клишин, А. В. Николаев А. П., Егоров, В. Н. Фрянов // Уголь. 2011. №12. C. 6-10.

\section{Title}

\section{MECHANIZED MINING OF THICK CRAGGED LAYERS WITH SUB-LEVELS WITH CONTROLLED COAL DRAW}

\section{Authors}

Klishin V.I., Opruk G.Y., Klishin S.V.

\section{Authors' Information}

Klishin V.I., director of Coal Institute of SB RAS, corr. member of RAS, Kemerovo, Russia, e-mail: klishinvi@icc.kemsc.ru

Opruk G.Y., chief technologist of Coal Institute, SB RAS, Kemerovo, Russia Klishin S.V., research scientist of Institute of Mining, SB RAS, ph.d. in technical sciences, Novosibirsk, Russia, e-mail: sv.klishin@gmail.com

\section{Abstract}

The article presents the development of technology for sublevel mining of thick cragged layers based on the controlled coal draw on the conveyor located between the paired sections of powered supports. The effluent is performed through the fences of these supports, providing coal extraction fullness and mining safety conditions. Physical modeling and numerical simulation of gravitational motion processes of granular materials using discrete elements were performed on a specially designed stand.

\section{Keywords}

Mining Method, Thick Cragged Layer, Powered Support, Sublevel Benching, Areal Effluent, Modeling On The Stand, Discrete Element Method.

\section{References}

1. Klishin V.I., Klishin S.V., and Opruk G.Y. Simulation of coal draw with mechanized mining of thick cragged layers. [Modelirovanie processa vypuska uglia pri mekhanizirovannoy otrabotke moshchnuykh krutopadayushchikh ugolnykh plastov]. FTPRI - PTPMM, 2013, No6, p.p.105-117.

2. Stanislaw Gajos. Experience and practical aspects of utilizing a shrinkage method of extraction at "Kazimierz-Juliusz" coal mine in Sosnowiec. International mining forum, New technologies in underground mining, Safety in mines. Cracow-Szczyrk-Wieliczka, Poland, 2004.

3. Klishin V.I., Fokin Y.S., Kokoulin D.I. et al. Mining of thick layers with powered supports with controlled coal draw [Razrabotka moshchnykh plastov mekhanizirovannymi "krepyami s reguliruemym vypuskom uglia]. Novosibirsk - Nauka, Novosibirsk - Science, 2007.

4. Klishin V.I., and Klishin S.V. Studding the process of coal draw at mining the thick cragged and flat coal layers. [Issledovaniya processa vypuska uglia pri otrabotke moshchnykh pologih i krutykh ugolnykh plastov] FTPRI - PTPMM 2010, No2, p.p.69-81.

5. Klishin V.I., Nikolaev A.V., Egorov A.P., and Fryanov V.N. Innovative solutions mining thick flat coal seams with the issue. [Perspektivnye tehnicheskie resheniya otrabotki moshchnykh pologih ugolnykh plastov s vypuskom] Ugol-Coal, 2011, No12, p.p.6-10. 


\section{Повышение устойчивости подземных}

\section{горных выработок угольных шахт, проводимых в многолетнемерзлых породах с применением сталеминеральной анкерной крепи}

\author{
РАЗУМОВ Евгений Анатольевич \\ Технический директор ООО «РАНК 2» \\ 2. Кемерово, Россия, тел.: +7 (3842) 56-09-83 \\ e-mail: rank2009@yandex.ru
}

\author{
СИДЕЛЬНИКОВ Александр Анатольевич \\ Главный инженер шахты «Джебарики-Хая», \\ канд. техн. наук \\ п. Джебарики-Хая, Республика Саха (Якутия), Россия
}

\author{
ГРЕЧИШКИН Павел Владимирович \\ Научный сотрудник Института угля СО РАН, \\ канд. техн. наук \\ 2. Кемерово, Россия, \\ тел.: +7 (3842) 28-12-03, e-mail: rank2009@yandex.ru
}

\section{позолотин Александр Сергеевич}

Директор по перспективному развитию

ООО «РАНК 2», канд. техн. наук

2. Кемерово, Россия,

тел.: +7 (3842) 56-09-83, e-mail: rank2009@yandex.ru

\section{ВЕНГЕР Вячеслав Геннадьевич}

Специалист по анкерному креплению ООО «РАНК 2»

2. Кемерово, Россия, тел.: + 7 (3842) 56-09-83,

e-mail: rank2009@yandex.ru

В статье представлены опыт применения и методическая база для расчета двухуровневой анкерной крепи подготовительных выработок угольных шахт, проводимых в многолетнемерзлых породах. Для обеспечения устойчивости вмещающих пород выработок, снижения темпов оттаивания и расслоения пород, их изоляции от воздействия шахтной атмосферы рассмотрено применение сталеминеральной анкерной крепи в сочетании с теплоизоляцией. Ключевые слова: угольная шахта, многолетняя мерзлота, анкерная крепь, ампулы с минеральной композицией, подготовительные выработки, теплоизолячионные материалы.

При разработке месторождений на севере и северовостоке России на угольных шахтах проведение горных выработок в многолетнемерзлых породах осуществляется с применением рамных крепей поддерживающего типа. При сезонном или прогрессирующем оттаивании вмещающих горных пород происходит резкое изменение их фи- зико-механических свойств и устойчивости, что приводит к деформациям и разрушению крепи. В зоне опорного горного давления впереди очистного забоя регулярно возникает необходимость перекрепления штреков. Это обусловливает постоянный рост эксплуатационных затрат на крепление и поддержание горных выработок в условиях многолетнемерзлых пород [1].

В сложных условиях норильских шахт при совокупном влиянии теплового режима и опорного давления от очистных работ получен положительный опыт поддержания выработок с применением железобетонной штанговой крепи в сочетании с крепью поддерживающего типа [2]. Известно, что преимущества усиления крепи канатными анкерами в сравнении с крепью поддерживающего типа сделало двухуровневую анкерную крепь практически безальтернативным вариантом при поддержании выработок в зоне влияния очистных работ на шахтах России и мира $[3,4]$.

Особенностью мерзлых пород является изменение их теплофизических свойств при достижении температуры таяния. Влажность - один из основных факторов, влияющих на устойчивость горных выработок. Она определяет многие специфические свойства мерзлыхпород, такие как: льдоцементация, анизотропность механических свойств и ползучесть. Вследствие цементации всех трещин и пор льдом горные породы обладают высокой устойчивостью, которая снижается при оттаивании. С изменением температуры мерзлых пород от - 4 до $0^{\circ} \mathrm{C}$ прочность на сжатие аргиллитов и песчаников уменьшается на 10\% [2].

Как показывает опыт работы шахты «Джебарики-Хая», оттаивание пород вокруг контура выработки $\Delta R_{\text {om }}$ в летнее время, когда в шахту подается теплый воздух, может достигать 0,5 м. В зоне оттаивания происходит значительное (до четырех раз) снижение прочностных показателей. Непосредственная кровля пласта «Верхний» сложена песчаником тонкозернистым, светло-серым, слоистость прерывистая, трещиноватым (75-90) мощностью 6 м с коэффициентом крепости по шкале проф. Протодьяконова в мерзлом состоянии $f=5-7$. С учетом снижения прочностных свойств при оттаивании породы непосредственной кровли можно отнести по обрушаемости к III типу, а по устойчивости к I классу [5]. Основная кровля представлена песчаниками серого цвета, кварцево-полешпатовый, цемент глинисто-кремнестый мощностью 14 м. Коэффициент крепости по шкале проф. Протодъяконова в мерзлом состоянии $f=5-7$. Глубина ведения горных работ от поверхности составляет 60-96,5 м.

В 1970-хгг. активно прорабатывались варианты поддержания горных выработок анкерной крепью при исполь- 
зовании полимерных теплоизоляционных материалов, в частности пенополистирола [6]. Однако пенополистиролы не получили широкого применения на шахтах из-за таких недостатков, как хрупкость, горючесть, малая гибкость, неудобство при монтаже и др.

На сегодняшний день существует рядтеплоизоляционных материалов, которые свободны от указанных недостатков и могут обеспечить теплоизоляцию приконтурных пород горных выработок и минимизировать их оттаивание.

При креплении экспериментального участка в условиях шахты «Джебарики-Хая», с целью изоляции приконтурного массива горных пород от растепляющего действия вентиляционной струи была применена стеклоткань. За счет отражающей способности поверхности стеклоткани произошло уменьшение потока тепловой энергии в приконтурный массив на 10-15\%. Это привело к снижению итоговой теплопроводности системы «приконтурный массив - крепление» и, соответственно, к уменьшению величины ореола оттаивания.

Величина ореола оттаивания с применением теплоизоляционных материалов для кровли и боков выработки была определена по формуле [1, 2]:

$$
\Delta R_{\text {OTT }}^{u 3}=\Delta R \quad\left(\frac{\lambda_{\text {э }}}{\lambda_{\Pi}}\right)^{0,43}, \mathrm{~m},
$$

где: величина ореола оттаивания [1, 2]:

$$
\Delta R_{\text {OTT }}=\frac{R_{0}^{0.14} \cdot t^{0.48} \cdot \lambda_{\Pi}^{0,43} \cdot \tau_{O T T}^{0,43}}{-T_{0}^{0,05} \cdot\left(0,8 \cdot W_{\Pi} \cdot \gamma\right)^{0,43}}, \mathrm{M},
$$

где: $R_{o}$ - эквивалентный радиус выработки, м; $\lambda_{n}$ - теплопроводность пород, ккал/м·град; $\tau_{\text {отm }}$ - время оттаивания, ч; $T_{o}$ - начальная температура массива пород, град; $W_{n}$ - влажность пород, \%; $\gamma$ - объемная масса пород, т/м³; $t$ - температура воздуха, град.

Расчет параметров анкерной крепи производился по инструкции [5] с учетом снижения прочности пород при оттаивании. Средневзвешенный коэффициент крепости пород непосредственной кровли пласта по шкале проф. М.М. Протодьяконова определялся по формуле [7]:

$$
f_{c p .83 в}=\frac{\left(m_{1} \cdot f_{1}+m_{2} \cdot f_{2}+m_{n} \cdot f_{n} \ldots\right) \cdot K_{c}}{B},
$$

где: $K_{c}-$ коэффициент снижения прочности; $m_{1}-$ зона подмерзлотных горизонтов, м; $m_{2} \ldots m_{n}$ - мощность зоны мерзлых пород, м; $B$ - ширина выработки, м; $f_{1}-$ коэффициент крепости пород по шкале проф. М.М.Протодьяконова в зоне оттаивания; $f_{2} \ldots f_{n}$ - коэффициент крепости породпо шкале проф. М.М. Протодьяконова в зоне мерзлых пород.

Величина возможного разрушения (отжима угля) боков выработки [7]:

$$
C=h \cdot \operatorname{ctg}\left(\frac{90^{0}+\beta_{\sigma}}{2}\right), \mathrm{m},
$$

где: $\beta_{\sigma}-$ угол внутреннего трения горных пород в боках выработки, вне зоны влияния очистных работ, град.; $h-$ высота выработки, с учетом зоны оттаивания, м.

Высота свода естественного равновесия пород кровли вне зоны влияния очистных работ:

$$
b_{1}=\frac{a}{f_{c p .638}}, \mathrm{M},
$$

где: $a$ - полупролет выработки с учетом возможного разрушения (отжима угля) боков выработки, м.

Расчет параметров анкерной крепи глубокого заложения выполнялся с использованием основных положений теории свода $[7,8]$.
Высота свода естественного равновесия пород кровли:

$$
b_{2}=\frac{a}{f_{c p .836} \cdot K_{c} \cdot K_{\text {влl }}},
$$

где: $K_{c}-$ коэффициент структурного ослабления [7]; $K_{в л}-$ коэффициент снижения сопротивления пород за счет воздействия влаги [9].

На основе методик $[1,10]$ для условий шахты «Джебарики-Хая» разработана схема анкерной крепи штрека (см. рисунок).

\section{КОНСТРУКЦИЯ АНКЕРНОЙ КРЕПИ}

Применение сталеполимерной анкерной крепи в шахтах, отрабатывающих запасы угля в условиях многолетней мерзлоты, осложнено по следующим причинам:

- при температуре воздуха - $10^{\circ} \mathrm{C}$ скорость отверждения смолы полимерных ампул примерно в десять раз меньше, чем при положительной температуре $+20^{\circ} \mathrm{C}[11]$;

- установку анкеров необходимо осуществлять до остывания стенок шпура, разогретых вследствие бурения;

- срок хранения полимерных ампул составляет 6 мес. с момента выпуска при температуре от +4 до $+20^{\circ} \mathrm{C}$;

- рекомендуемая температура применения полимерных ампул составляет $+20^{\circ} \mathrm{C}$, однако в районах многолетней мерзлоты обеспечить такие температурные условия хранения и применения крайне затруднительно.

В условиях золотых рудников ОАО «Бурятзолото» более двух лет успешно применяется сталеминеральная анкерная крепь. На руднике «Ирокинда», в условиях многолетней мерзлоты, и на шахте «Зун-Холбинская», в условиях островной мерзлоты, анкеры АКМ 20.01-01 производства ООО «АМК» закрепляют на ампулы с минеральной композицией типа АМК.

11 апреля 2012 г. в условиях шахты «Джебарики-Хая» на главном вентиляционном штреке ПК-280 была проведена установка канатных анкеров типа АК01 и комбинированных анкеров типа АКМ 20.01-01 в мерзлые породы. Анкеры устанавливались на ампулы АМК-400. После установки были проведены испытания крепи на фактическую несущую способность по методике [12], которые подтвердили заявленные характеристики анкерной крепи (табл. 1).

Гарантийный срок хранения ампул АMК — не менее одного года при температуре от -50 до $+50^{\circ} \mathrm{C}$. Технические характеристики ампул АМК представлены в табл. 2.

\section{КРЕПЛЕНИЕ ЭКСПЕРИМЕНТАЛЬНОГО УЧАСТКА}

Крепление экспериментального участка выработки производилось на участке протяженностью 10 м анкерной крепью по двухуровневой схеме (см. рисунок). Первый уровень в кровле на протяжении $10 \mathrm{M}$ формировался анкерами AKM 20.01-01, длиной $L=2,6$ м, которые устанавливаются совместно с продольным подхватом гофрированным типа «штрипс» (В-300), длиной $L=4,2$ м. Крепление боков было выполнено анкерами АКМ 20.01-01, длиной $L=2,2$ м. Перетяжка кровли и боков экспериментального участка выполнялась металлической решетчатой затяжкой с ячейкой $50 \times 125$ мм и 50×50 мм, соответственно, в сочетании со стеклотканью. Стеклотканью производилась теплоизоляция контура выработки перед анкерованием. Протяженность участка, закрепленного по двухуровневой схеме, составила 3 м. Для второго уровня крепления приняты канатные анкеры АК01 длиной 6 м. Все анкеры были закреплены в шпурах диаметром 30 мм на ампулы AMK. 

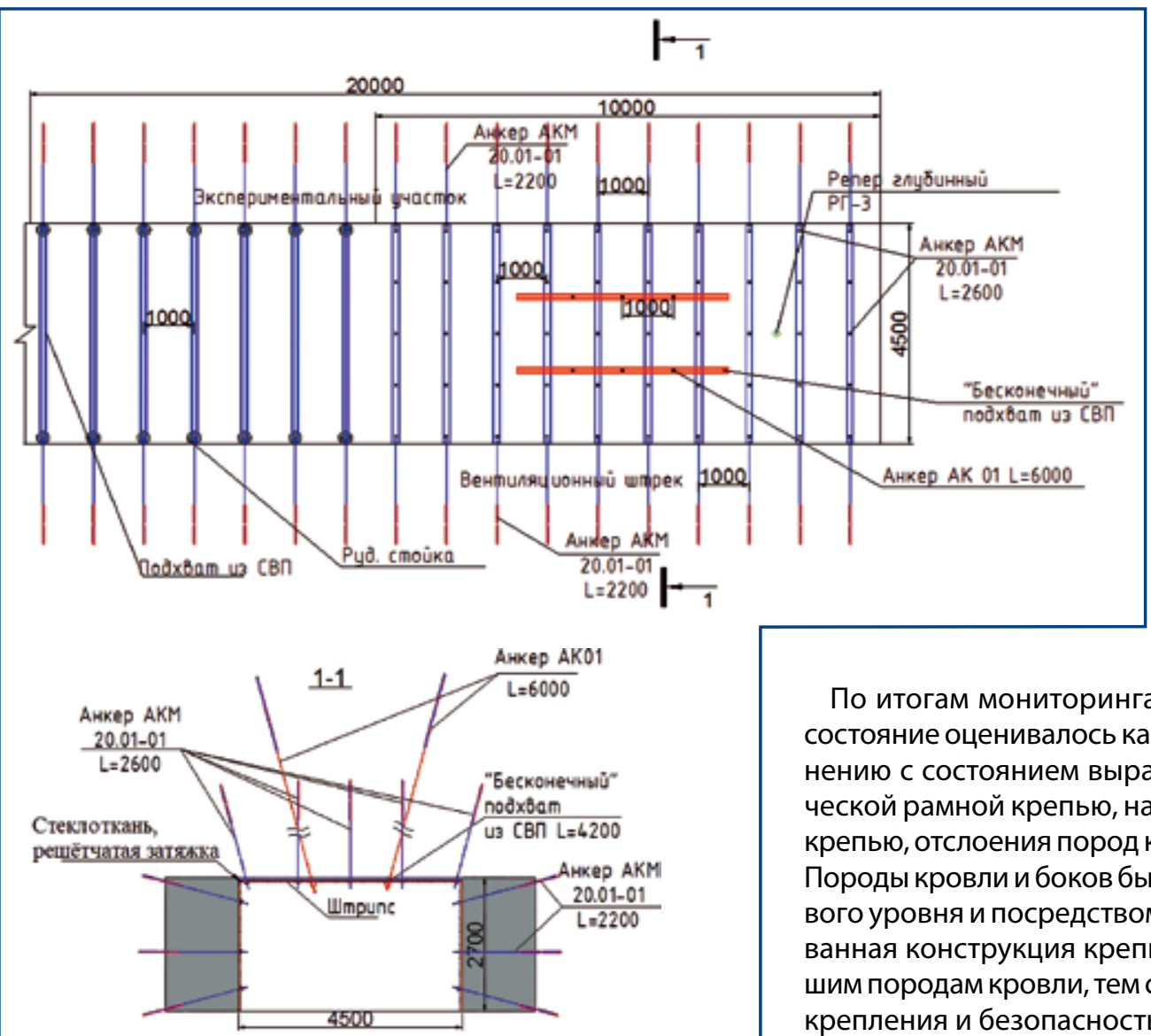

Схема крепления экспериментального участка вентиляционного штрека №10 на шахте «Джебарики-Хая»

Таблица 1

Технические характеристики анкеров АКМ 20.01-01, АК01

Анкер комбинированный АКМ 20.01-01 Наименование

Диаметр шпура, мм

Значение

Длина стержня анкера, мм

Длина резьбовой части не менее, мм

$27-45$

Расчетная несущая способность, кH

$500-3500$

200

110

10

Рекомендуемая величина предварительного натяжения, кH

\begin{tabular}{|c|c|}
\hline \multicolumn{2}{|l|}{ Канатный анкер АК01 } \\
\hline Наименование & Значение \\
\hline Расчетная несущая способность, кН & 210 \\
\hline $\begin{array}{l}\text { Относительное удлинение анкера } \\
\text { при нагрузке } 210 \text { кН, не более, \% }\end{array}$ & 1,3 \\
\hline $\begin{array}{l}\text { Прочность соединения гайки с муфтой, } \\
\text { не менее, кН }\end{array}$ & 270 \\
\hline $\begin{array}{l}\text { Рекомендуемая величина предварительного } \\
\text { натяжения анкера, кH }\end{array}$ & 10 \\
\hline Диаметр грузонесущего стержня, мм & 15,2 \\
\hline Длина муфты с резьбой, мм & 120 \\
\hline
\end{tabular}

Таблича 2

Технические характеристики ампулы АМК

\begin{tabular}{|l|c|c|}
\multicolumn{1}{|c|}{$\begin{array}{c}\text { Наименование } \\
\text { показателей }\end{array}$} & АМК400 & АМК600 \\
\hline Длина, мм & 400 & 600 \\
\hline Диаметр, мм & $23 ; 32 ; 36 ; 40$ & $23 ; 32 ; 36 ; 40$ \\
\hline
\end{tabular}

В процессе монтажа анкерной крепи выполнялся хронометраж:

- суммарное время крепления одного погонного метра выработки анкерами первого уровня (кровля, бока) составляет 81 мин.;

- суммарное время крепления одного погонного метра выработки анкерами второго уровня (кровля), составляет 21 мин.;

- суммарное время крепления одного погонного метра выработки (ширина 4,5 м, высота 2,7 м) анкерной крепью в два уровня составляет $102 \mathrm{мин.}$

По итогам мониторинга выработки в зимний период, состояние оценивалось как удовлетворительное. По сравнению с состоянием выработок, закрепленных металлической рамной крепью, на участке выработки с анкерной крепью, отслоения пород кровли и боков не наблюдалось. Породы кровли и боков были плотно сшиты анкерами первого уровня и посредством канатных анкеров, сформированная конструкция крепилась к устойчивым, не оттаявшим породам кровли, тем самым обеспечивая надежность крепления и безопасность поддержания выработки.

Состояние участка, закрепленного по двухуровневой схеме, и участка, закрепленного анкерами первого уровня, были одинаково удовлетворительными. Выработка находилась вне зоны опорного давления. Контроль за смещениями пород кровли производился с помощью реперной станции РГ-3.

По итогам мониторинга состояния опытного участка выработки в летний период, когда воздух, подаваемый в шахту, имеет плюсовую температуру, было выявлено следующее:

- состояние приконтурного массива выработки (кровля, бока), удовлетворительное;

- индикаторы на реперной станции РГ-3, находятся в зеленой зоне, существенных смещений пород кровли не происходит;

- наличие трещин, проявления горного давления в кровле и боках не наблюдается;

- вывалов пород между анкерами, отслоений приконтурных слоев кровли не зафиксировано;

- наличия пустот и трещин между подхватами и элементами анкерной крепи, уменьшения высоты и ширины выработки не обнаружено;

— провисание решетчатой металлической затяжки между подхватами отсутствует;

- деформации с изгибами или с разрывом анкерных подхватов отсутствуют;

— ослабление гаек на анкерах отсутствует.

\section{выводы}

1. Разработанная конструкция сталеминеральной анкерной крепи обеспечивает ее надежное закрепление в многолетнемерзлых породах.

2. Эффективность использования сталеминеральной анкерной крепи обусловлена сохранением ее работоспособности в широком диапазоне температур хранения и применения в условиях многолетней мерзлоты. 
3. Разработана методика расчета параметров двухуровневой анкерной крепи, учитывающая применение теплоизоляционных материалов для обеспечения устойчивости вмещающих пород выработок, снижения темпов их оттаивания и расслоения.

4. Результаты мониторинга состояния экспериментального участка на шахте «Джебарики-Хая», поддерживаемого двухуровневой сталеминеральной анкерной крепью с изоляцией приконтурного массива, подтверждают эффективность данного вида крепи в сравнении с рамной крепью поддерживающего типа.

\section{Список литературы}

1. Методика расчета параметров анкерной крепи подземных горных выработок угольных шахт, проводимых в многолетнемерзлых породах/ Е. А. Разумов, П.В. Гречишкин, А. С. Матвеев и др. // Уголь. 2014. №1. С. 4-7.

2. Скуба В.Н. Совершенствование разработки угольных месторождений области многолетней мерзлоты. Якутск: Якутское книжное издательство, 1974. 317 с.

3. Современные технологии анкерного крепления: опыт применения и перспективы / В.И. Клишин, П.В. Гречишкин, А. А. Серов, Е.А. Разумов // Научно-техн. журнал «Рудник будущего». 2012. №3 (11). С. 89-96.

4. Ground support liners for underground mines: energy absorption capacities and costs / V.N. Louchnikov, V.A.
Eremenko, M.P. Sandy // Eurasian Mining (Gornyi Zhurnal). 2014. №1 (21). pp. 54-62.

5. Инструкция по расчету и применению анкерной крепи на угольных шахтах России. СПб., 2000. 70 с.

6. Авксентьев И. В., Скуба В.Н. Исследование устойчивости и теплоизоляция горных выработок в условиях многолетней мерзлоты. М.: ЦНИЭИуголь, 1975. 45 с.

7.Механика горныхпород и устойчивость выработокшахт Кузбасса / В.М. Станкус [и др.]; под ред. В.Г. Кожевина. Кемерово: Кемеровское книжное издательство, 1973. 345 с.

8. Цимбаревич П. Н. Механика горных пород. М.:Углетехиздат, 1948. 184 с.

9. Методика расчета и выбора параметров крепи на сопряжениях горных выработок при одинарной и парной подготовке выемочных столбов. СПб., 2004. 84 с.

10. Методика расчета параметров анкерной крепи подземных горных выработок в условиях вечной мерзлоты / Е. А. Разумов, В. А. Еременко, Д.Ф. Заятдинов и др. // ГИАБ. 2013. №9. С. 39-47.

11. Васильев С.Д. Обоснование и разработка методики расчета крепления сталеполимерной анкерной крепью горных выработок для условий многолетней мерзлоты: автореферат дис.... канд. техн. наук. М., 2013. 24 с.

12. Методика шахтных испытаний отдельных положений «Инструкции по расчету и применению анкерной крепи на угольных шахтах Кузбасса - Первая редакция». СПб.: ВНИМИ, 2010. 12 c.

\section{Title}

INCREASING THE STABILITY OF UNDERGROUND MINE WORKINGS OF COAL MINES WITH PERMAFROST CONDITIONS USING RESIN-GROUTED ROOF BOLTING

\section{Authors}

Razumov E.A., Sidelnikov A.A., Grechishkin P.V., Pozolotin A.S., Venger V.G.

\section{Authors' Information}

Razumov E.A., technical director of «RANK 2» Itd., Kemerovo, Russia, tel.: +7 (3842) 56-09-83, e-mail: rank2009@yandex.ru

Sidelnikov A.A., chief engeneer of «Dzhebariki-Khaya» mine, ph.d. in technical sciences, vil. Dzhebariki-Khaya, Sakha Republik (Yakutia), Russia

Grechishkin P.V., research scientist of Coal Institute of SB RAS, ph.d. in technical sciences, Kemerovo, Russia, tel.: +7 (3842) 28-12-03, e-mail: rank2009@yandex.ru Pozolotin A.S., director on long term growth of «RANK 2»Itd., ph.d. in technical sciences, Kemerovo, Russia, tel.: +7 (3842) 56-09-83, e-mail: rank2009@yandex.ru Venger V.G., specialist in anchorage of «RANK 2», Kemerovo, Russia, tel.: +7 (3842) 56-09-83, e-mail: rank2009@yandex.ru

\section{Abstract}

The article presents the experience of application and methodological basis for the calculation of a two-level roof bolting of development workings of coal mines with the permafrost conditions. The use of resin-grouted roof bolting in conjunction with thermal insulation is considered to ensure the stability of the workings adjacent rocks, slowdown thawing and rocks lamination, their isolation from the impact of the mine atmosphere.

\section{Keywords}

Coal Mine, Permafrost, Roof Bolting, Ampoules with Mineral Composition Entries, Thermal Insulation Materials.

\section{References}

1. Razumov E.A. Grechishkin P.V., Matveev A.S., et al. Methods of parameters calculating for roof bolting of underground digging of coal mines in the permafrost solids [Metodika rascheta parametrov ankernoy krepi podzemnykh gornykh vyrabotok ugolnykh shaht, provodimykh $v$ mnogolet nemerzlykh porodah]. Ugol-Coal, 2014, No1, p.p.4-7.

2. Scuba V.N. Improving coal mining in the region of permafrost. [Sovershenstvovanie razrabotki ugolnykh mestorozhdeniy oblasti mnogoletney merzloty Yakutsk, Yakutskoe knizhnoe izdatelstvo - Yakutsk Publishing House, 1974. 317 p. 3. Klishin V.I., Grechishkin P.V., Serov A.A., and Razumov E.A. Modern technologies of roof bolting: application experience and prospects. [Sovremennye tehnologii ankernogo kreplenia: opyt primenenia I perspektivy] Nauchno-tehnicheskiy zhur- nal "Rudnik budushchego" - Scientific and Technical. magazine "Mine of the Future", 2012, №3 (11) S.89-96.

4. Louchnikov V.N., Eremenko V.A., and Sandy M.P. Ground support liners for underground mines: energy absorption capacities and costs. Gornyi Zhurnal Eurasian Mining, 2014, No1 (21), pp54-62.

5. Instructions for calculation and use of roof bolting in the coal mines of Russia, [Instrukcia po raschetu i primeneniyu ankernoy krepi na ugolnykh shahtah Rosii] St. Petersburg, 2000, 70 p.

6. Avksent'ev I.V., and Scuba V.N. Investigation of stability and thermal insulation in mining with permafrost conditions. [Issledovanie ustoychivosti I teploizoliatsia gornyh vyrabotok v usloviah mnogoletney merzloty] Moscow, TsNIElugol CSRIESTI, 1975. 45 p.

7. Stankus V.M. et al. Mine rock mechanics and stability of Kuzbass mines workings [Mehanika gornykh porod I ustoychivost vyrabotok shaht Kuzbassa]. Kemerovo, Kemerovskoe knizhnoe izdatelstvo — Kemerovo Publishing House, 1973, 345 p.

8. Tsimbarevich P.N. Mine rock mechanics. [Mehanika gornykh porod] Moscow, Ugletehizdat 1948, 184 p.

9. Method for calculation and choosing the parameters of walling in joined mine workings at single and double preparation of extraction columns. [Metodika rastcheta I vybora parametrov krepi na sopriazheniyah gornykh vyrabotkakh pri odinarnoy I parnoy podgotovke vyemochnykh stolbov] St. Petersburg, 2004, 84 p.

10. Razumov E.A., Eremenko, V.A., Zayatdinov D.F. et al. Methods for parameters calculation of roof bolting of underground mine workings with permafrost conditions. [Metodika rastcheta parametrov ankernoy krepi podzemnykh gornykh vyrabotok v usloviah vechnoy merzloty] GIAB - MIAB, 2013, №9, S.39-47.

11. Vasilyev S.D. Validation and development of calculation method for fixing the resin-grouted roof bolt in minings with permafrost conditions. [Obosnovanie I razrabotka metodiki rascheta kreplenia stakepolimernoy ankernoy krepyu gornykh vyrabotok dlia usloviy mnogoletney merzloty], abstract of ph.d. thesis in tehn. sciences. Moscow, 2013, 24 p.

12. Mining test method for particular provisions of the "Instruction on calculation and use of roof bolting in coal mines in Kuzbass. First edition [Metodika shahtnykh ispytaniy otdelnykh polozheniy"Instruktsii po raschetu I primeneniyu ankernoy krepi na ugolnykh shahtah Kuzbassa. Pervaya redaktsia" Pervoe izdanie] St. Petersburg, VNIMI - ARRIDI, 2010, 12 p. 


\section{Опыт применения насыпных перемычек}

\section{для вскрытия и отработки рабочих горизонтов разреза ОАО «Черниговец»}

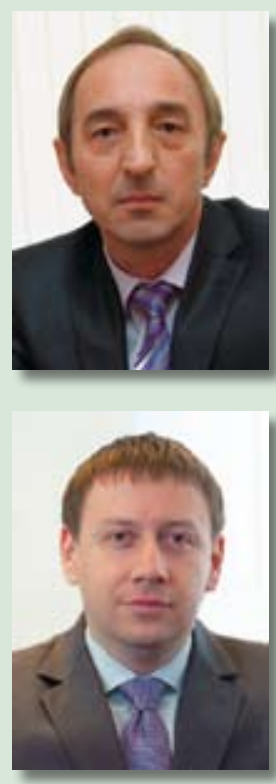

\section{СИДОРОВ}

Роман Владимирович

Директор ООО «Сибирский институт горного дела»

2. Кемерово, Россия, e-mail:r.sidorov@pk-ugol.ru

\section{КОРЧАГИНА}

\section{Татьяна Викторовна}

Заместитель директора ООО «Сибирский институт горного дела», канд. техн. наук 2. Прокопьевск, Россия, e-mail: t.korchagina@pk-ugol.ru

\section{MЕЗИНА}

\section{Екатерина Николаевна}

Главный инженер проекта ООО «Сибирский институт горного дела» г. Прокопьевск, Россия

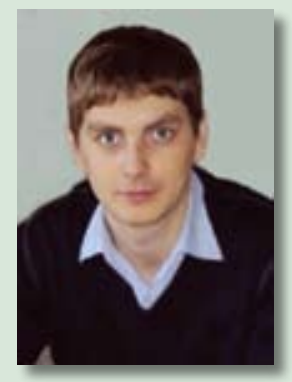

\section{ВОРОШИлИн}

Аспирант кафедры

ТО НИТУ «МИСИС» (МГИ)

Москва, Россия
Рассмотрен один из способов вскрытия карьерных полей с помощью насыпных транспортных перемычек.

Ключевые слова: горные работы, полезное ископаемое, рабочий уступ, насыпные перемычки, вскрышные породы, отвалообразование, экономический эффект.

В вопросах вскрытия карьерных полей важнейшую роль имеет формирование карьерных грузопотоков. Для создания необходимых условий формирования грузопотоков вскрыши и полезного ископаемого используются разные способы вскрытия, в том числе с помощью земляных сооружений (насыпных перемычек) или временных целиков.

Особое распространение этот способ получил на месторождениях с большой протяженностью фронта горных работ и перемещением вскрышных пород автотранспортом на внутренние отвалы.

При отсутствии насыпных транспортных перемычек вскрышные породы перевозятся во внутренний отвал по дорогам, расположенным на рабочем борту и в торцах карьера, что существенно увеличивает расстояние транспортирования и уменьшает угол наклона рабочего борта и, соответственно, затраты на вскрышные работы.

Насыпные перемычки соединяют нижнюю и среднюю части рабочей зоны карьера с ярусами внутреннего отвала по кратчайшему расстоянию, что существенно снижает расстояние транспортирования вскрышных пород и транспортные расходы на разработку (рис. 1).

Насыпные перемычки являются временными сооружениями, не приводящими к консервации запасов и увеличению норматива потерь. Время их существования колеблется от нескольких месяцев до нескольких лет. При подвигании фронта горных работ они срабатываются и понижаются совместно с блоками (панелями) по рабочему борту.

В поперечном сечении насыпная перемычка имеет, как правило, форму трапеции. Ширина ее верхней площадки рассчитывается, исходя из двухполосного движения автосамосвалов. Параметры насыпных перемычек определяются высотой и интенсивностью развития рабочей зоны карьера, мощностью вскрышных грузопотоков, приемной способностью выработанного пространства и другими факторами.

В настоящее время насыпные перемычки применяются на угольных разрезах: «Черниговский», «Тугнуйский», «Нерюнгринский», «Первомайский» и ряде рудных карьеров. 


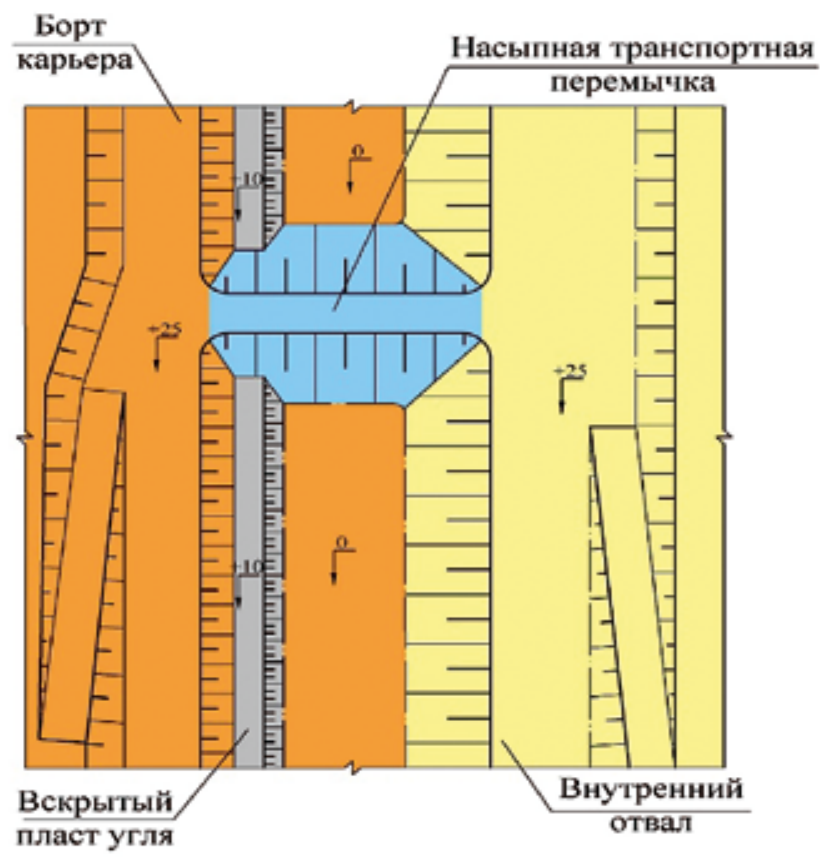

Puc. 1. Схема насыпной транспортной перемычки
Характерной особенностью разреза «Черниговский» является значительная длина рабочей зоны, составляющая порядка 7 км. Вскрытие рабочих горизонтов осуществляется внутренними траншеями в торцах карьерной выемки и двумя перемычками. Горные работы выполняются на трех эксплуатационных участках (два участка - с применением автотранспорта, один - сприменением железнодорожного транспорта).

Вскрышные породы верхних горизонтов отрабатываются на железнодорожный транспорт с последующим вывозом и размещением во внешних железнодорожных отвалах. Вскрышные породы средних и нижних горизонтов разреза отрабатываются с применением автомобильного транспорта. Транспортирование и размещение вскрышных пород средних и нижних горизонтов разреза производятся во внутренние и частично во внешние отвалы.

Горно-геологические особенности Кедровско-Крохалевского месторождения позволяют размещать значительную часть вскрышных пород в выработанном карьерном пространстве. В настоящее время на разрезе «Черниговский» существуют две перемычки. Средняя

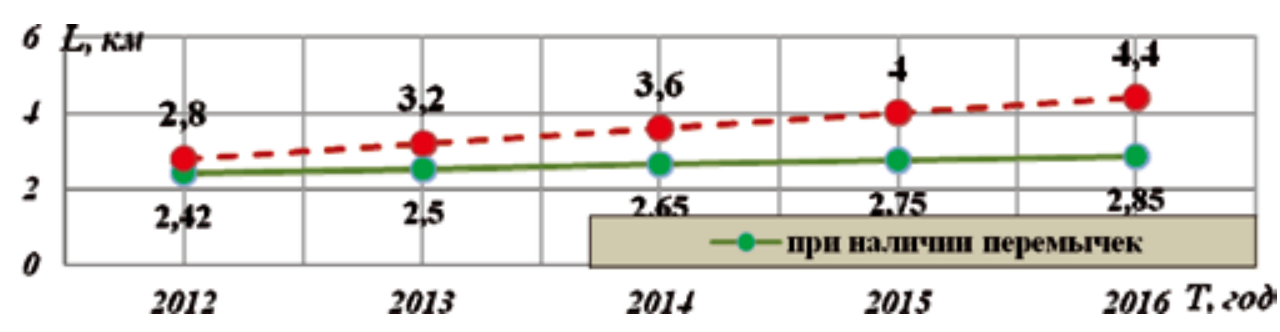

Рис. 2. Графики изменения среднего расстояния транспортирования вскрышных пород (для условий ОАО «Черниговец»)

Puc. 3. Транспортная перемычка 


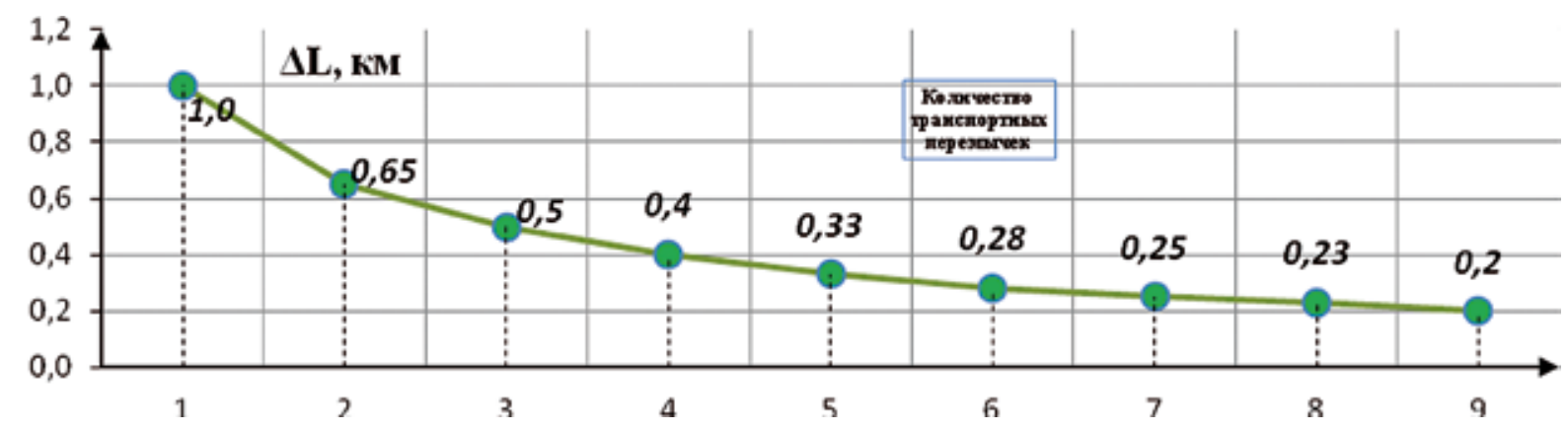

Pис. 4. График снижения расстояния транспортирования $(\Delta L$, кM) при увеличении количества насыпных транспортных перемычек, формируемых в рабочей зоне карьера (для разреза с общей протяженностью фронта, равной 8 км)

длина перемещения вскрышных пород в зонах с применением транспортных перемычек является относительно небольшой и укладывается в интервал 2,5-2,9 км. В свою очередь при перемещении автомобильным транспортом вскрышных пород через торцы разреза расстояние транспортирования достигает значений 3,2-4,4 км (рис. 2).

Формирование перемычки выполняется в два этапа. Первый этап предполагает частичную выемку вскрышных пород в зоне нижних горизонтов рабочего борта и отсыпку основания перемычки. Второй этап реализуется посредством применения бульдозерно-автомобильной схемы отвалообразования (рис. 3).

Укрупненно оценить целесообразность использования насыпных транспортных перемычек можно на базе сравнения экономии эксплуатационных затрат за счет сокращения расстояния транспортирования и величины затрат на экскавацию и перемещение объемов вскрышных пород, возникающих при отсыпке и отработке перемычки.
Транспортные перемычки разделяют фронт горных работ на выемочные блоки длиной 1,5-1,8 км, что является оптимальным параметром для работы экскаваторно-автомобильного комплекса. С увеличением числа транспортных перемычек удельная величина сокращения расстояния транспортирования вскрышных пород резко снижается (рис. 4).

Предварительный анализ экономических показателей эффективности использования насыпных транспортных перемычек свидетельствует о том, что их высота не должна превышать уровня 140-150 м, а их число в рабочей зоне не должно быть более двух. Часть рабочих уступов рабочего борта разреза, расположенных выше предельной высоты насыпной транспортной перемычки должна вскрываться временными автомобильными съездами. В этом случае при предельной высоте перемычки 140-150 м общая высота уступов рабочего борта, обслуживаемая данной вскрывающей выработкой, может составлять 195-210 м.

UDC 622.271.45:622.271:622.221:622.33.012.3 "Chernigovets" $\odot$ V.A. Gushinets,

Title

EXPERIENCE OF USING THE EARTH-FILL COFFERDAMS FOR OPENING AND MINING OF PRODUCING LEVELS AT THE OPEN-PIT MINE OF "CHERNIGOVETS"

\section{Authors}

Gushinets V.A., Sidorov R.V., Korchagina T.V., Mezina E.N., Voroshilin K.S.

\section{Authors' Information}

Gushinets V.A., technical director of :SDS-Ugol" JSC HC, Kemerovo, Russia, e-mail: v.gushinets@hcsds.ru

Sidorov R.V., director of "Siberian Institute of mining affairs" Itd, Kemerovo, Russia, e-mail: r.sidorov@pk-ugol.ru

Korchagina T.V., deputy director of "Siberian Institute of mining affairs"Itd, ph.d. in technical sciences, Prokopyevsk, Russia,

e-mail: t.korchagina@pk-ugol.ru

Mezina E.N., chief engineer of "Siberian Institute of mining affairs" Itd. project, Prokopyevsk, Russia

Voroshilin K.S., post graduate of TO department, National Research Technological University, "Moscow Institute of Steel and Alloys" (MSU),

Moscow, Russia

\section{Abstract}

One of the ways for opening the open-pit field with the bulk transport stopping is considered.

\section{Keywords}

Mining, Minerals, Work Bench, Earth-Fill Cofferdam, Stripping Soils, Economic Effect. 


\section{Очередной производственный рекорд установлен на Назаровском разрезе}

\begin{abstract}
Очередной производственный рекорд установлен в 3 АО «Разрез Назаровский» (входит в группу лич ОАО «Сибирская угольная энергетическая компания»). Бригада работающего на вскрышном
\end{abstract} участке экскаватора ЭШ-20/90 №19 под руководством Сергея Голынчика в середине октября переместила в отвал пятимиллионный кубометр породы с начала 2014 года.

«Настолько высокий результат на машине такой марки достигнут впервые за более чем 60-летнюю историю предприятия», - отметил руководитель Назаровского разреза Юрий Килин. Он пожелал бригаде экскаватора безаварийной работы и новых трудовых успехов.

Одним из главных слагаемых успешной работы Юрий Килин назвал «человеческий фактор». Бригада Сергея Голынчика, потомственного горняка и полного кавалера знака «Шахтерская слава», с начала года установила уже несколько трудовых рекордов. В профессиональный праздник «День шахтера» члены бригады были удостоены «золотых» именных касок СУЭК - награда не является официально признанной, но в полной мере отражает отношение к вскрышникам экскаватора ЭШ-20/90 №19 как К «золотому фонду» компании.

Еще одной предпосылкой для высокопроизводительной работы стало внедрение на экскаваторе рационализаторского предложения по реконструкции механизма шагания. Отремонтирован ряд основныхузлов, обновлено электрическое оснащение машины. Все это в конечном итоге позволило значительно повысить коэффициент технической готовности экскаватора.

Кроме того, машина оборудована автоматизированной системой учета ковшей. Такое нововведение значительно увеличило мотивацию экипажа трудиться с максимальной отдачей. Организовано соревнование между экипажами. Все это дало свои результаты. С начала года производительность труда экипажа экскаватора Сергея Голынчика выросла более чем на $29 \%$, еще одного экипажа-рекордсмена под управлением Сергея Можгина - на $18 \%$.

С очередной трудовой победой вскрышников поздравил и исполнительный директор ОАО «СУЭК-Красноярск» Андрей Федоров: «Каждый новый рекорд назаровцев доказывает, что их возможности и профессионализм не имеют предела, и они полны сил и энергии для новых свершений. Желаю не снижать достигнутой производительности, сибирского здоровья, счастья и благополучия».

\section{Наша справка}

ОАО «Сибирская угольная энергетическая компания» (СУЭК) - крупнейшее в России угольное объединение по объему добычи. Компания обеспечивает около $30 \%$ поставок угля на внутреннем рынке и примерно $25 \%$ российского экспорта энергетического угля. Предприятия СУЭК расположены в Красноярском, Забайкальском, Приморском и Хабаровском краях, Кемеровской области, Республиках Бурятия и Хакасия.

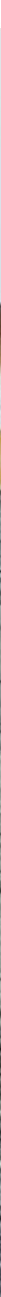




\section{О подходе к решению задач многовариантного анализа компоновки оборудования при проектировании новых производств}

\author{
СТАРОДУБОВ Алексей Николаевич \\ Старший научный сотрудник \\ Института угля СО РАН, канд. техн. наук \\ 2. Кемерово, Россия, \\ тел.: +7 (3842) 74-10-45, \\ e-mail:a.n.staodubov@gmail.com
}

\author{
ЗИНОВЬЕВ Василий Валентинович \\ Старший научный сотрудник \\ Института угля СО РАН, \\ канд. техн. наук, дочент \\ г. Кемерово, Россия, \\ тел.: +7 (3842) 74-10-45
}

\section{ДОРОФЕЕВ Михаил Юрьевич}

Ведущий инженер Института угля СО РАН

2. Кемерово, Россия, тел.: +7 (3842) 74-10-45

Предложен подход для решения задач многовариантного анализа и выбора оптимального варианта компоновки оборудования при проектировании новых производств. Созданы имитационные модели, отображающие работу автоматизированных производственных систем в машиностроении и энерготехнологических систем по переработке угля. Показана возможность решения широкого круга задач по исследованию этих систем и компоновки оборудования.

Ключевые слова: автоматизированное проектирование, компоновка оборудования, автоматизированные производственные системы, энерготехнологические системы, имитационное моделирование.

В современных рыночных условиях существует необходимость создания новых, высокоэффективных автоматизированных производственных систем в машиностроении (АПС) и энерготехнологических комплексов по глубокой переработке угля в энергетике (ЭТК), обеспечивающих изготовление продукции небольшими партиями при сохранении производительности, качества и себестоимости, как при крупносерийном производстве.

Исследования научных разработок показали, что на сегодняшний день нет продукта или метода, позволяющего с высокой скоростью и достаточной точностью разработать сложную производственную систему с заданными или наилучшими параметрами.

Предлагаемые аналитические и численные методы часто не позволяют описать отдельные элементы системы и взаимодействие между ними, приходится применять серьезные упрощения и допущения, чтобы отобразить динамику моделируемой системы. Немалую роль в работе системы играют внецикловые потери времени, вызванные простоями технологического оборудования. Имеющиеся методики расчета учитывают внецикловые потери статическим коэффициентом, который приблизительно определяется только для типовых существующих производств. Между тем внецикловые потери существенно влияют на производительность системы и могут составлять до $40 \%$ технологического времени [1, 2].

Наиболее эффективным является имитационное моделирование, при котором динамика системы отображается в ЭВМ некоторым алгоритмом, моделирующим ее поведение [3].

Имитационное моделирование отображает динамику взаимодействия элементов системы во времени и пространстве, кроме того, оно эффективно, когда необходимо прослеживать динамику развития процесса в нестандартных и аварийных ситуациях, а также на очень коротких и очень длинных промежутках времени. Большинство таких задач не поддаются аналитическому решению.

Наиболее распространен специализированный язык GPSS (General Purpose Simulation System). В машиностроении язык GPSS применен для моделирования транспортной системы, проектирования систем конвейеров и др. [4].

Для разработки моделей автоматизированных производств и проведения имитационных экспериментов разработаны классификации компоновок АПС и ЭТК. В основе классификации лежит используемая автоматизированная транспортно-складская система (АТСС): рольганг, автоматизированная тележка, кран-штабеллер, мостовой кран и кран-балка, промышленный робот, конвейер для АПС и система конвейеров, перегружателей, складов, дробилок и углезагрузочных машин для ЭТК.

Автоматизированное производство представляется в виде системы массового обслуживания (CMO). Функционирование рабочего места (т. е. единицы технологического оборудования и промышленного робота) отображено многоканальной однофазной или многофазной СМО, где параллельно работающие приборы будут обслуживать заявки, и моделировать совместное выполнение операций. Подобная СМО имеет стандартное формульное математическое описание.

Несколько рабочих мест при помощи транспортноскладской системы объединяются в АПС или ЭТК. Показано, что любая автоматизированная производственная система отображается сетью многофазных одноканальных и/или многоканальных СМО без отказов с простейшей дисциплиной обслуживания FIFO и ограниченным вход- 

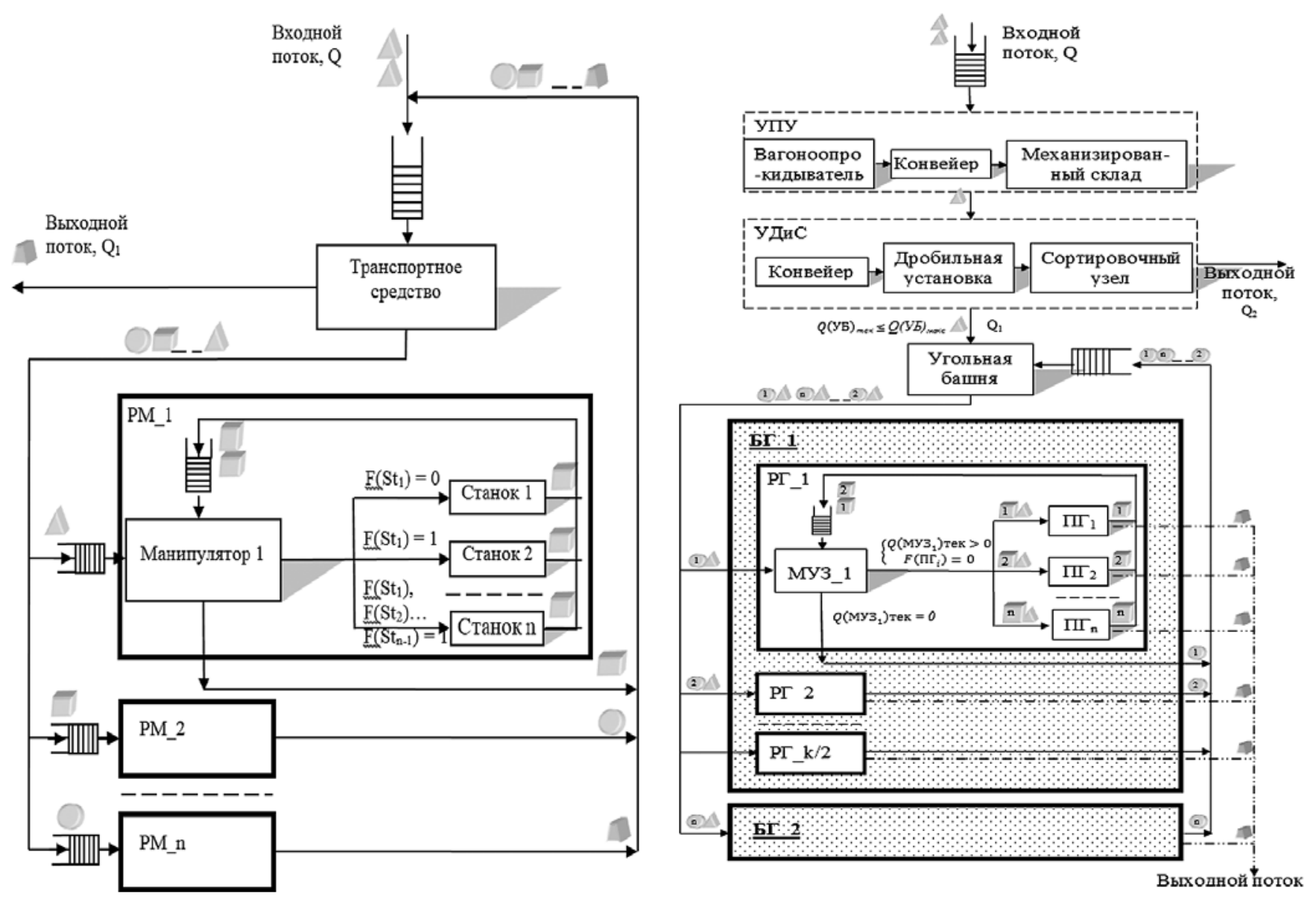

Puc. 1. АПС (а) и ЭТК (б) в виде сети многофазных многоканальных СМО без отказов

ным потоком заявок который соответствует производственному плану. Заявками являются заготовки или партии угля. Обслуживание заявок заключается в задержке их на время выполнения операций фрезерования, сверления, точения, газификации и др., в приборах, имитирующих оборудование АПС или ЭТК. Выходной поток представляет готовые изделия или полукокс (рис. 1).

Проблемой такого подхода является сложность математического описания сети СМО. В настоящее время существуют различные методики решения подобных сетей. Некоторые авторы предлагают разбивать сеть СМО на более мелкие системы, приводя их к какой-либо стандартной классификации, например символике Кендалла (общий вид: $\mathrm{G} 1 / \mathrm{G} 2 / \mathrm{m} / \mathrm{N} / \mathrm{r} / \mathrm{f} . .$.$) . Однако в таком случае получить$ реальные характеристики системы не представляется возможным. Исходя из вышеуказанного, для решения задачи получения характеристик элементов СМО и всей сети в целом был применен имитационный подход.

На основе полученной системы массового обслуживания АПС с различным типом применяемого транспортного средства представляются в виде блок-схемы, и с использованием языка GPSS созданы имитационные модели. Например, на рис. 2 представлен фрагмент блоксхемы имитационной модели ЭТК с углезагрузочными машинами.

На основе построенных блок-схем с использованием специализированного языка имитационного моделиро- вания GPSS $[5,6]$ разработаны модели AПС и ЭТК с различными типами применяемой АТСС.

Имитационные модели построены на данных о времени выполнения операций. Для верификации и валидации модели использован метод построения логической блок-схемы и интерактивный контроль хода моделирования при помощи режима отладки, а также аналитический подсчет характеристик и сравнение их с модельными результатами (рис. 3).

Проведена декомпозиция модели, и проверена работа всех подсистем. В таблице представлено сравнение результатов имитационных экспериментов и аналитических расчетов для модели АПС из крана-штабелера и одного рабочего места в виде СМО по классификации КендаллаБашарина - 2*M/M/1.

Максимальное отклонение результатов имитационных экспериментов от аналитических расчетов составило не более 1,5\%. Аналогичным образом проверены имитационные модели остальных подсистем АПС и ЭТК, максимальное отклонение составило $7 \%$.

На рис. 4 представлены экранные формы комплексов программ моделирования АПС и ЭТК, построенные согласно предлагаемому подходу.

Анализ полученных данных позволяет выявить эффективные пути повышения производительности и загрузки оборудования для вариантов автоматизированных производств. Пример подобного анализа, полученных массивов данных, представлен на рис. 5. 


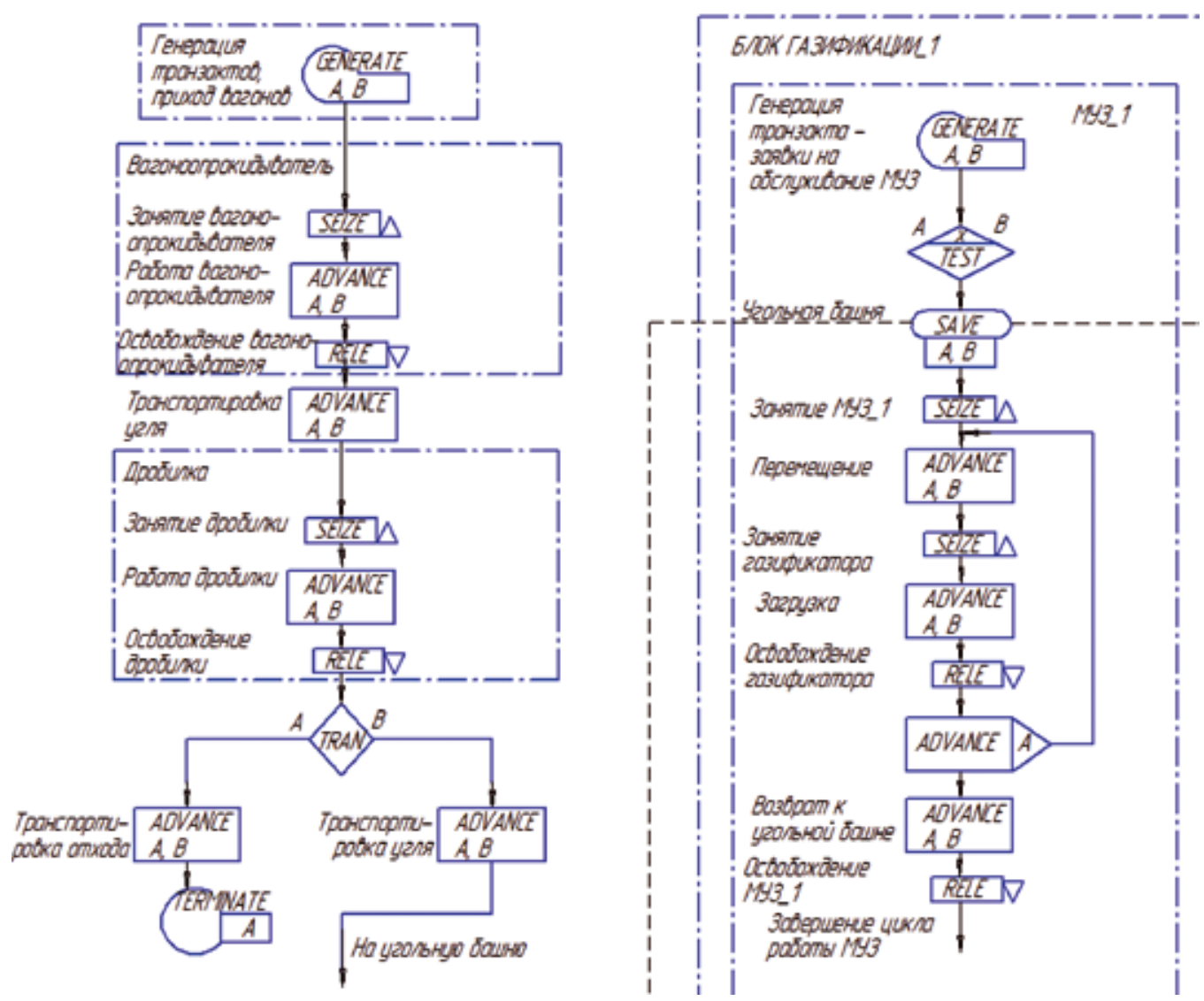

PUс. 2. Фрагмент блок-схемы GPSS-модели ЭTK

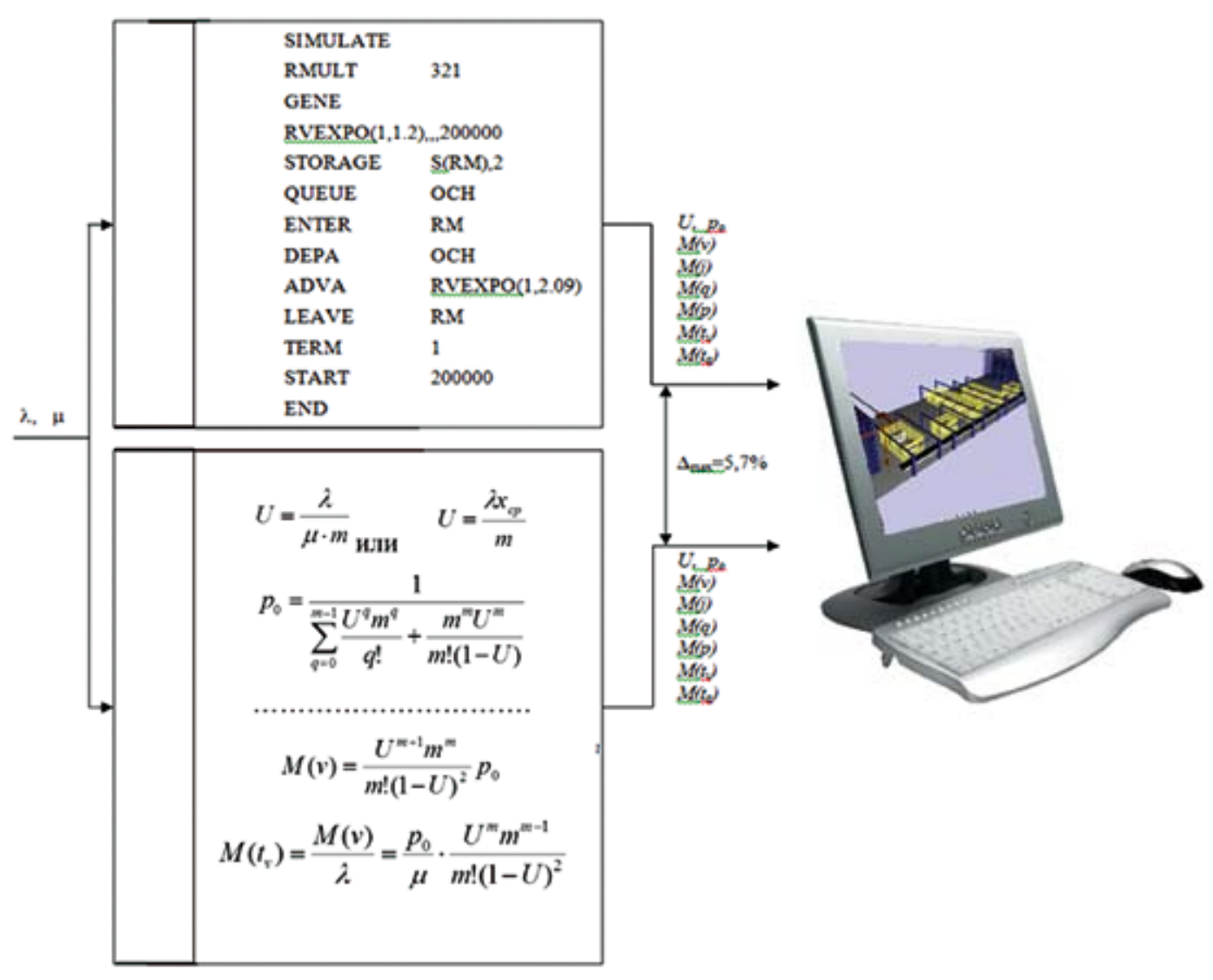

Рис. 3. Принципиальная схема валидации моделей АПС и ЭТК: $\lambda$ - интенсивность поступления требований; $\mu-$ интенсивность обслуживания требований; $a-$-среднее время интервалов между поступлениями требований; $x_{c p}-$ среднее время обслуживания требований 


\section{Сравнение результатов имитационных экспериментов и аналитических расчетов} для модели АПС (CMO - 2*M/M/1)

\begin{tabular}{|c|c|c|c|c|c|c|}
\hline \multirow[b]{2}{*}{ Наименование характеристики } & \multicolumn{3}{|c|}{ Первая СМО } & \multicolumn{3}{|c|}{ Вторая СМО } \\
\hline & $\begin{array}{l}\text { Аналитичес- } \\
\text { кие расчеты }\end{array}$ & $\begin{array}{c}\text { Результаты } \\
\text { имитационных } \\
\text { экспериментов }\end{array}$ & $\begin{array}{l}\text { Отклоне- } \\
\text { ние, \% }\end{array}$ & $\begin{array}{c}\text { Анали- } \\
\text { тические } \\
\text { расчеты }\end{array}$ & $\begin{array}{c}\text { Результаты } \\
\text { имитационных } \\
\text { экспериментов }\end{array}$ & $\begin{array}{l}\text { Отклоне- } \\
\text { ние, \% }\end{array}$ \\
\hline Коэффициент загрузки & 0,276 & 0,275 & 0,36 & 0,381 & 0,381 & 0 \\
\hline Вероятность, что система свободна & 0,724 & 0,725 & 0,14 & 0,619 & 0,618 & 0,16 \\
\hline Среднее число требований в системе, шт. & 0,381 & 0,379 & 0,79 & 0,616 & 0,618 & 0,32 \\
\hline Среднее число требований в очереди, шт. & 0,105 & 0,104 & 0,96 & 0,235 & 0,237 & 0,8 \\
\hline $\begin{array}{l}\text { Среднее время пребывания требования } \\
\text { в системе, ч }\end{array}$ & 0,400 & 0,399 & 0,25 & 0,648 & 0,654 & 0,92 \\
\hline
\end{tabular}

a

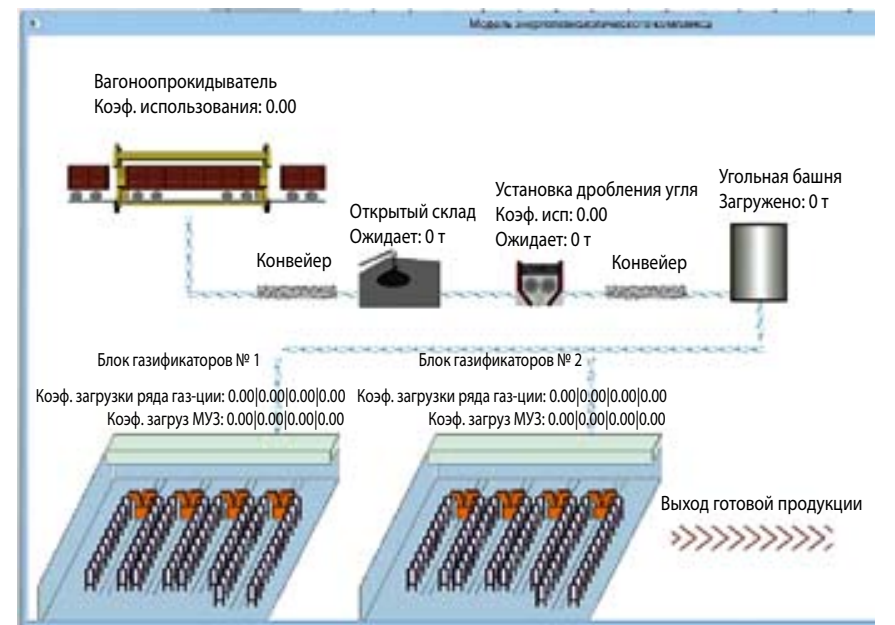

6

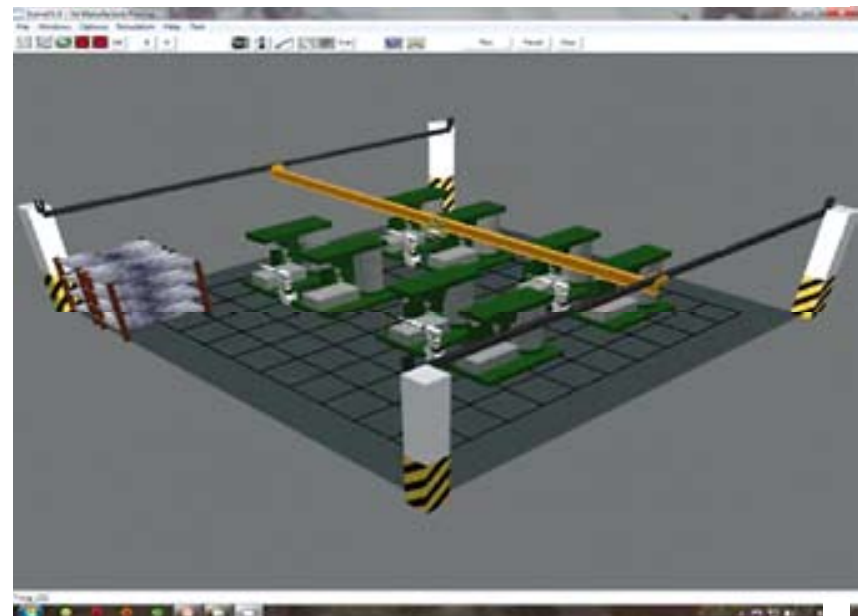

Pис. 4. Скриншот комплексов программ моделирования АПС (а) и ЭТК (б)

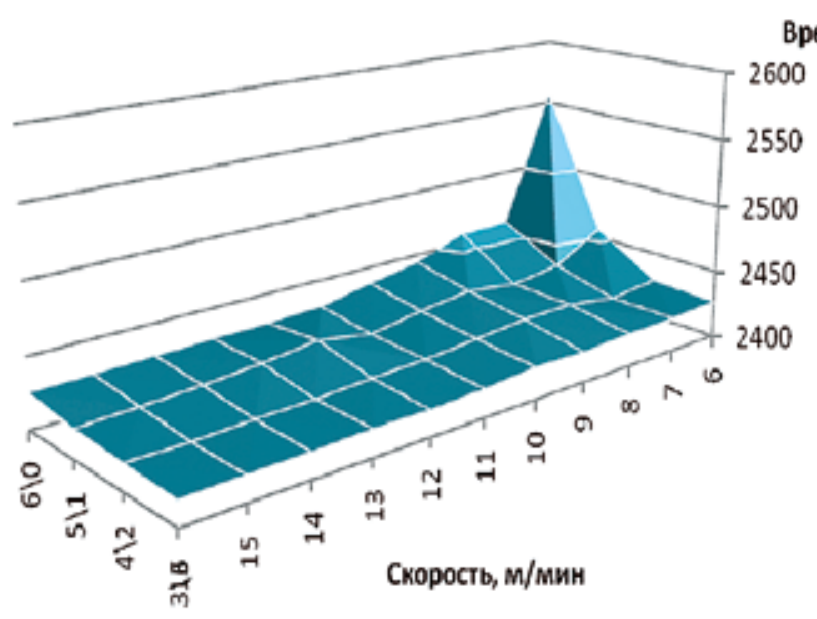

Планировка

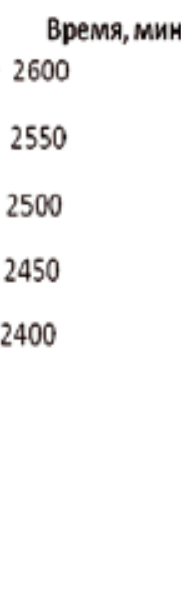

Puc. 5. Пример обработки результатов экспериментов для АПС (а) и ЭТК (б)
Таким образом, предложенный подход позволяет решать широкий круг задач по исследованию систем и компоновке оборудования при проектировании новых автоматизированных машиностроительных производств и энерготехнологических систем по глубокой переработке угля. Реализация такого подхода позволяет на предпроектной стадии находить эффективные пути повышения производительности и степень использования оборудования, выявлять и устранять «узкие места» в системе.

\section{Список литературы}

1. Проектирование компьютерно-интегрированных производственных систем / В.А. Полетаев, В.В. Зиновьев, А.Н. Стародубов и др. М.: Машиностроение, 2011. 324 с.

2. Методология сквозного изготовления изделий машиностроения: в 2-х т. Т. 2. / В. А. Полетаев, В. В. Зиновьев, А. Н. Стародубов и др. Кемерово: КузГТУ, 2013. 225 с.

3. Стародубов А.Н. Обобщенная структура модели энерготехнологического комплекса в виде систем массового 
обслуживания // ГИАБ (Отдельный выпуск). М.: Горная книга, 2013. №6 (ОВ). С. 145-151.

4. Зиновьев В.В., Кочетков В.Н. Опыт имитационного моделирования сложных производственных систем // Вычислительные технологии. Новосибирск: ИВТ СО РАН, 2008. T. 13. №5 (Спецвыпуск). С 51-55.
5.Имитационный подход при моделировании энерготехнологического комплекса по переработке угля / В.В. Зиновьев, А.Н. Стародубов, А. Е. Майоров и др. // Энергетик. 2013. №1. С. 26-29.

6. Моделирование энерготехнологического комплекса по глубокой переработке угля / А.Н. Стародубов, В.В. Зиновьев, М. Ю. Дорофеев // Уголь. 2010. №2. С. 8-12.

UDC 658.5:622.33:622.7:658.012.011.56ASU ๑ A.N. Starodubov, V.V. Zinoviev, M.Y. Dorofeev, 2014

ISSN 0041-5790 • UGOL №11-2014/1064/

Title

ABOUT THE APPROACH OF PERFORMING MULTIVARIATE ANALYSIS

OF EQUIPMENT CONFIGURATION DURING DESIGNING NEW PRODUCTIONS

Authors

Starodubov A.N., Zinoviev V.V., Dorofeev M.Y.

\section{Authors' Information}

Starodubov A.N., chief scientist of Coal Institute of SB RAS, ph.d.

in technical sciences, Kemerovo, Russia, tel.: +7 (3842) 74-10-45,

e-mail: a.n.staodubov@gmail.com

Zinoviev V.V., chief scientist of Coal Institute of SB RAS, ph.d. in technical sciences, доцент, Kemerovo, Russia, tel.: +7 (3842) 74-10-45

Dorofeev M.Y., leading engineer of Coal Institute of SB RAS, Kemerovo,

Russia, tel.: +7 (3842) 74-10-45

\section{Abstract}

The article presents the new approach for performing multivariate analysis and choosing the best option for the equipment configuration during designing new productions. The simulation model was created, showing the operation of automated manufacturing systems in the engineering and energy technology systems for the coal processing. It has been shown the possibility of solving a wide range of tasks on studding these systems and equipment configuration.

\section{Keywords}

Computer-Aided Design, Equipment Configuration, CAM Systems, Energy Technological Systems, Simulation Modelling.

\section{References}

1. Poletaev V.A., Zinoviev V.V., Starodubov A.N. et al. Designing computer integrated production systems. [Proektirovanie kompyutorno-integrirovah- hyh proizvodstvwennykh sisyem] Moscow, Mashinostroenie - Mechanical Engineering, 2011, 324 p.

2. Poletaev V.A., Zinoviev V.V., Starodubov A.N. et al. Methodology of the through manufacturing of engineering products, [Metodoligia skvoznogo izgotovleniya izdeliy mashinostroeniya] volume 2. Kemerovo, KuzGTU KuzSTU, 2013, 225 p.

3. Starodubov A.N. Generalized structure of the energy technological complex model as queue systems [Obobshchennaya structura modeli energotehnologicheskogo kompleksa $v$ vide system massovogo obslugivania]. MIAB (separate issue). Moscow, Gornaya kniga - Mountain Book 2013, № 6 (OM), S.145-151.

4. Zinoviev V.V., and Cochetkov V.N. Simulation experience of complex production systems. [Opyt imitatsionnogo modelirovania slozhnykh proizvodstvennykh sistem] Kompyuternye tehnologii - Computational technologies. Novosibirsk, CTI SB RAS, 2008, Volume 13, №5 (Special Issue), C 51-55.

5. Zinoviev V.V., Starodubov A.N., Mayorov A.E. et al. Simulation approach for simulation of energy technological complex for coal processing. [Imitatsionniy podhod pri modelirovanii energotehnologicheskogo kompleksa po pererabotke uglia] Energetika - Energetic, 2013, №1, S.26-29.

6. Starodubov A.N. Zinoviev V.V., and Dorofeev M.U. Simulation of energy technological complex for deep coal processing. [Modelirovanie energotehnologicheskogo kompleksa po glubokoy pererabotke uglia] Ugol - Coal, 2010, №2, S.8-12.

\section{В Кузбассе подведены итоги работы летнего трудового отряда СУЭК}

В Кемеровской области состоялось закрытие и подведение итогов летней работы Трудовых отрядов СУЭК. В этом году проект компании объединил более 200 подростков из городов Ленинск-Кузнецкий и Киселевск в возрасте от 14 до 18 лет.

Юные бойцыленинск-кузнецкого трудотряда за трижарких летних месяца собрали более полутора тысяч мешков мусора и скошенной травы, вскопали и пропололи 24 цветочные клумбы, высадили более сотни деревьев возле Ледового дворца и в Лесном городке, приняли участие в экологической акции по очистке от мусора берега р. Иня. Также ребята собирали вещи первой необходимости для переселенцев с Юго-Востока Украины, оказывали адресную помощь ветеранам Великой Отечественной войны и труда, инвалидам.

Бойцы киселевского трудотряда СУЭК за лето благоустроили территории четырнадцати общеобразовательных учреждений Киселевского городского округа, подготовили к новому учебному году кабинеты двенадцати школ, оказали адресную помощь десяткам ветеранов. Трудотрядовцы приняли участие в работах по восстановлению и ремонту памятника и часовни в с. Верх-Чумыш Киселевского городского округа, сделали множество полезных дел на территориях загородныхлагерей «Таежный», «Гвоздика» и «Радуга», храмового комплекса в честь иконы Божьей Матери Скоропослушницы, а также других социально-значимых объектов города.
На торжественных мероприятиях, посвященных закрытию летнего трудового сезона, бойцов поздравили представители администраций и Центров занятости городов Ленинск-Кузнецкий и Киселевск. Семнадцать киселевских подростков за отличную работу получили планшеты и электронные книги. В Ленинске-Кузнецком наиболее отличившимся в трудовых делах ребятам вручили сертификаты на приобретение цифровой техники и спортивной одежды. Четверо самых активных ребят были награждены поездкой в Москву, где они вместе с трудоторядовцами Красноярского края встретились с руководством СУЭК, побывали на экскурсиях по самым интересным местам столицы.

Проект «Трудовые отряды СУЭК» реализуется в Кузбассе второй год. В 2013 г. первый отряд СУЭК появился в ЛенинскеКузнецком, в 2014 г. трудотряд начал работать в Киселевске.

Проект проводится в рамках соглашений о партнерстве между Фондом «СУЭК-РЕГИОНАМ», местными региональными администрациями, Молодежными биржами труда и Центрами занятости населения. СУЭК обеспечивает на время летних каникул занятость и финансирование труда старшеклассников, которые активно участвуют в благоустройстве своей малой родины. Проект реализуется в Красноярском крае с 2005 г., в 2013 г. отряды СУЭК начали работу также в Бурятии, Приморском и Хабаровском краях. 


\section{МОДЕРНИЗИРОВАННЫЕ БУЛЬДОЗЕРЫ \\ ЧETPA T35.02}

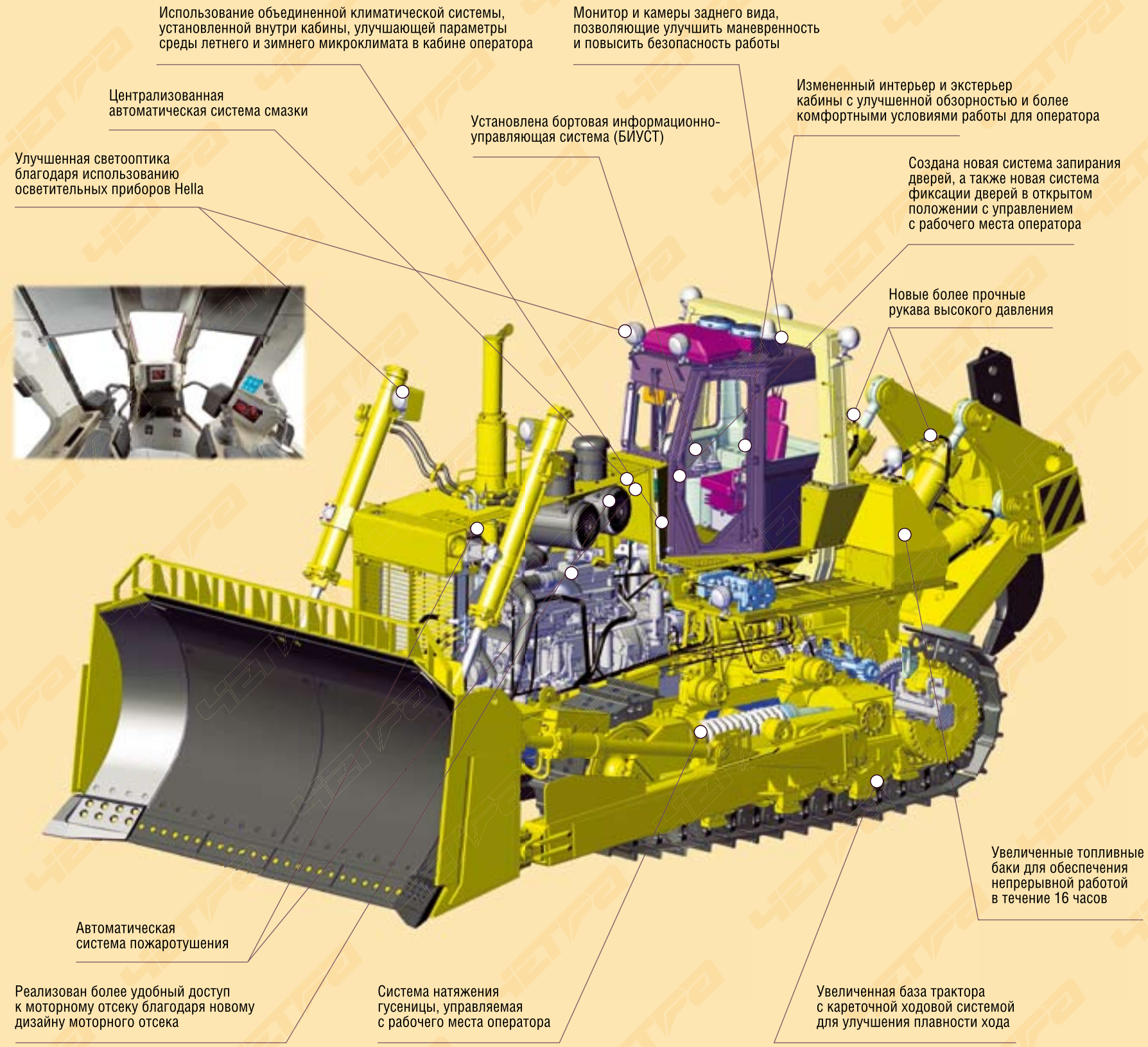

\section{Производство ОАО «Промтрактор»}

«Концерн «Тракторные заводы» 


\section{Первый шаг на польский рынок горной техники}

19 сентября 2014 г. в Польше в 2. Катовице состоялась торжественная презентация передачи проходческого комбайна КПД, произведенного компанией Corum Group, польской угольной компании Jastrzębska Spółka Węglowa S. A.(JSWSA). Презентация прошла с демонстрацией конструктивных особенностей техники и ее основных преимуществ.

В Польшу комбайн КПД поставляется в результате победы в тендере, который проходил в два этапа. На первом этапе все участники проходили технический отбор, затем был этап коммерческого отбора, проводился открытый онлайн-аукцион в Интернете. Компания Corum Group сделала лучшее предложение и выиграла. Отметим, что польский рынок имеет одну характерную особенность (рынок проходческой техники) - польские шахты не покупают проходческие комбайны. Они их берут в аренду. Этот комбайн будет поставляться на условиях аренды на два года. После чего будет возвращен обратно компании Corum Group.

«Комбайн КПД сертифицирован по европейским стандартам. В аукционе участвовали польские, американские и другие европейские производители. Характерной особенностью рынка горношахтного оборудования Польши является - аренда. Они платят ежемесячно аренду. У нас есть уже опыт поставки в аренду российским компаниям», - уточнил директор Дивизиона подземной разработки компании Corum Group Ильдар Салеев. - «Для нас выгоден этот вид сотрудничества, это повышает нашу готовность и дисциплину, дает дополнительные конкурентные преимущества по сравнению с теми, кто этого сделать не может, позволяет обеспечивать полное сопровождение работы комбайна на всем этапе его жизненного цикла и обеспечить конечный результат. Уже нельзя сказать, что мы представляем машины. Мы по большому счету оказываем нашим клиентам услугу по достижению конечного результата. Кому-то удобно, чтобы это была поставка машин, а кто-то хочет, чтобы это было результатом - $1 \mathrm{~m}, 1 \mathrm{м} \mathrm{или} 1 \mathrm{~m} \cdot \mathrm{KM}$ um. ..».

\section{Проходческий комбайн КПД}

Предназначен для разрушения горного массива с крепостью пород до 100 МПа, погрузки и транспортировки разрушенной горной массы при проходке подготовительных выработок различной формы площадью сечения от 11 до 30 кв м. Модель выгодно отличается от своих предшественников инновационной конструкцией поворотной секции конвейера, усиленной металлоконструкцией основных элементов, увеличенным ресурсом редуктора исполнительного органа и рядом других изменений.

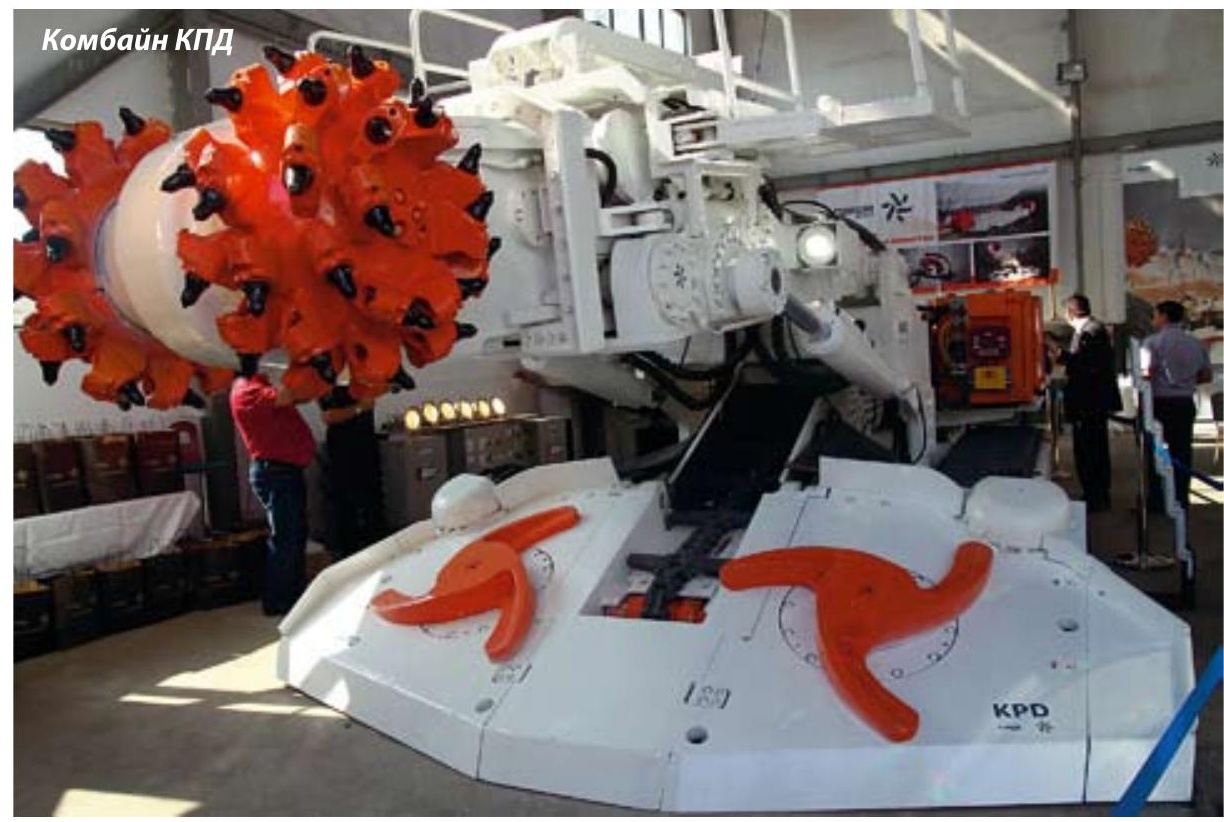

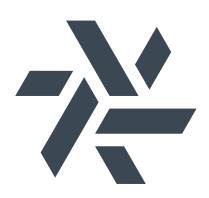

Представленная на презентации модель проходческого комбайна КПД наиболее успешна, и необходимо отметить, что на машине стоит номер 71, а это означает, что 70 ед. техники уже работают на горных предприятиях. Еще в 2012 г. комбайн КПД производства компании Corum Group получил Гран-При на международной выставке «Уголь России и Майнинг». В августе 2013 г. комбайн установил рекорд по проходке в Украине, на шахте «Южнодонбасская №1», пройдя за месяц 707 м горных выработок площадью сечения 13 кв. м. В этом же году комбайн КПД признан одним из лучших среди 39 ед. техники подобного типа, работающих на угледобывающих предприятиях компании «АрселорМиттал Темиртау» в Казахстане.

«Отличительной особенностью добычи «черного золота» в Польше является больший средний объем добычи и скорость подвигания лавы, что требует более высоких темпов проведения выработоки выдвигает повышенные требования к проходческим комбайнам. Наш КПД неоднократно демонстрировал свою надежность и высокую производительность в различных странах. Уверены, что и польские горняки по достоинству оченят все преимущества нашего оборудования», - отметил Ильдар Салеев. - «Мы активно осваиваем рынок Польши. Год назад наша компания открыла на территории страны представительство, и уже в ближайшей перспективе мы планируем увеличить долю экспорта. Так, к середине 2015 г. планируем отгрузить в Польшу пять единии такой техники».

При реализации польского проекта комбайн КПД был оснащен коронками с поперечной осью вращения, разработанной по специальным требованиям заказчика. Стреловидный телескопический исполнительный орган с поперечной или продольной осью вращения, обеспечи- 
вающий эффективное разрушение горного массива с сохранением устойчивого положения комбайна. Есть также возможность установки трех типов электродвигателей исполнительного органа: 110 и 132 кВт $\left(n=1500\right.$ мин $\left.^{-1}\right), 90$ кВт $\left(n=1000\right.$ мин $\left.^{-1}\right)$, обеспечивающих выбор наиболее экономически эффективного режима резания пород различной прочности. Электродвигатели на комбайне - польского производства, изготовленные фирмой «Damel».

Комбайн полностью гидрофицирован, на нем стоит установка охлаждения рабочей жидкости, обеспечивающая ограничение температуры нагрева масла в гидросистеме комбайна не более $65^{\circ} \mathrm{C}$. Скребковый конвейер армирован полосами из износостойкой стали, повышающими его ресурс в 2-3 раза, а поворотная секция конвейера повышенной надежности, исключающая применение гибких листов.

Проходческий комбайн оснащен электронной системой визуализации, которая позволят контролировать и при необходимости планировать профилактические работы различных узлов. Кроме того, управление комбайном осуществляется с помощью выносного пульта с использованием радиосигнала или гибкого кабеля. Это позволяет машинисту находиться в наиболее удобном для него месте, что в конечном итоге влияет на производительность техники в целом.

Вопрос сервисного обслуживания техники - одно из самых основных направлений в развитии компании. Можно производить хорошее оборудование, но, если не сопровождать его на всем этапе жизненного цикла, то это всегда риски плохой репутации, риски испорченных отношений
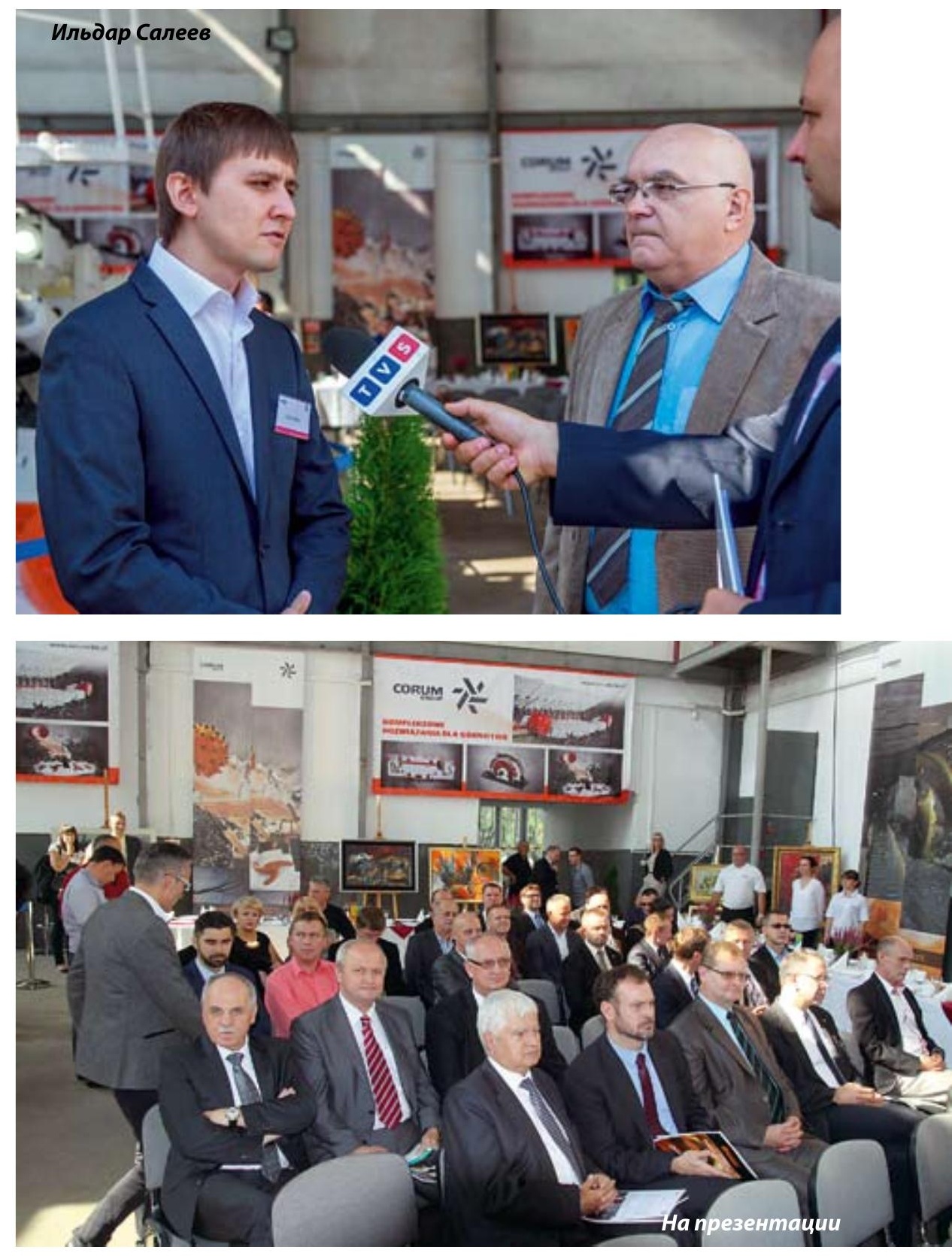
с клиентом - считают специалисты Corum Group. Поэтому предусмотрено обязательное обучение польских шахтеров работе на комбайне КПД специалистами компании Corum Group.

Отвечая на вопросы журналистов, директор Дивизиона подземной разработки компании Corum Group подчеркнул, что «главная движущая сила Corum Group - интеллектуальный ресурс, умноженный намноголетний практический опыт. Это сочетание позволяет предлагать клиентам новые разработки и многократно улучшать характеристики существующих продуктов». Он также рассказал о применении в компании ОЕМ-системы, философия которой заключается в том, чтобы концентрироваться на том, что лучше всего можешь делать. — «Мы лучше всего разрабатываем и производим горное оборудование. Но для производства оборудования нужны различные компоненты. Есть производители, которые специализируются именно на производстве компонентов. Кто-то лучше делает гидравлику, кто-то электрооборудование. Поэтому мы начелены на то, чтобы выбирать лучшее, выстраивать

долгосрочные отношения с партнерами. Чтобы каждый делал то, что у него лучше получается», - отметил Ильдар Салеев.

\section{Corum Group - \\ эксперт горнодобывающего бизнеса}

Ключевой компетенцией компании Corum Group является экспертиза в горнодобывающем бизнесе. Деятельность компании сосредоточена на предоставлении высокотехнологичных комплексных решений, производстве и сервисе оборудования в области добычи, переработки и транспортировки полезных ископаемых, а также строительстве шахт.

B Corum входят семь заводов и ремонтные площадки в Украине и России, торговые компании в Украине, России, Казахстане, Польше и Вьетнаме.

Дополнительную информацию можно получить на сайте www. corum. com

Официальные представительства в социальных сетях: Facebook, linkedin, youtube. 


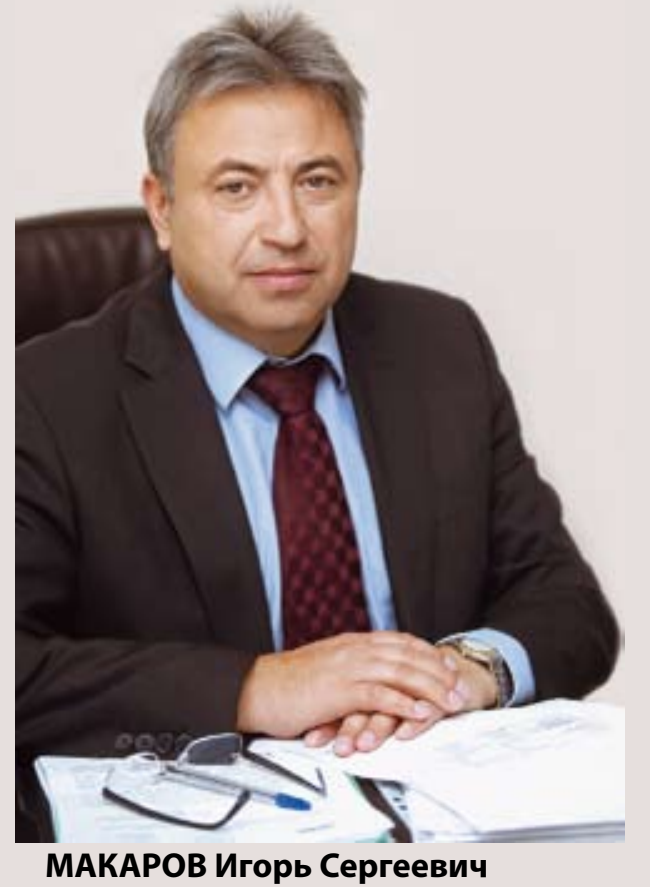

Руководитель дирекции по сервису «Силовые машины»,

г. Санкт-Петербург, Россия

\section{Комплексный сервис:} всерьез и надолго

«Развитие долгосрочного комплексного сервиса от производителя - одно из наших стратегчческих направлений»

И. С. Макаров

Чем более совершенным становится оборудование для энергетики, тем большее значение приобретает его качественный сервис. Именно поэтому сервисное направление сегодня активно развивают все лидеры мирового энергомашиностроения, $a$ доля сервисных контрактов в общем портфеле ихзаказов становится все более значимой. О новых видах сервисных услуг, предоставляемых компанией “Силовые машины», рассказывает руководитель дирекции по сервису Игорь Сергеевич Макаров.

- Игорь Сергеевич, какова на сегодняшний день доля сервисных договоров в обцем портфеле контрактов «Силовых машин»?

- Эта доля составляет около $15 \%$. И в ближайшие годы наша задача довести ее до $25 \%$ общего объема портфеля.

- По каким направлениям идет развиmuе сервисных услуг компании?

- Во-первых, продвижение долгосрочного сервиса как на вновь установленном, так и на модернизированном оборудовании. Во-вторых, продвижение пакетов модернизации собственного оборудования с цельюулучшения его параметров и продления срока эксплуатации. Третье направление - модернизация оборудования других производителей. И, наконец, расширение линейки услуг, предоставление новых их видов: сервис систем управления и автоматики, увеличение продаж запасных частей к собственному оборудованию, сервис крупных электрических машин и тяговых двигателей собственного производства, в том числе тяговых двигателей для БелЛАЗов, производство которых мы сейчас активно наращиваем. В настоящее время мы формируем группу, которая будет заниматься организацией и оказанием сервисных услуг именно для этого вида оборудования. Комплекс услуг будет включать не только поставку запасных частей, но и оказание ремонтных услуг как непосредственно на площадке заказчиков, так и на наших производственных площадях.
Активно развивается и такое направление сервиса, как оказание консультационных услуг по эксплуатации установленного оборудования. «Силовые машины» предоставляют консультации с использованием всего объема современных коммуникационных технологий в любом удобном для заказчика виде: устном, письменном, электронном, без выезда или с выездом на место.

- Таким образом, сегодня клиенты «Силовых машин» имеют возможность получить непосредственно у производителя полный комплекс сервисных услуг для всех видов оборудования?

- Совершенно верно. Как я уже сказал, наши сервисные услуги включают технические консультации всех видов, техподдержку и техруководство при ремонтах, выполнение монтажных, ремонтных и наладочных работ своим персоналом или с привлечением квалифицированных монтажных и ремонтных организаций, обследование оборудования, модернизацию и реконструкцию, подготовку эксплуатационной и ремонтной документации, помощь в формировании ведомостей запчастей и расходных материалов, специального инструмента и так далее. При этом конкретный перечень услуг и степень вовлеченности персонала «Силовых машин» определяются в соответствии с пожеланием заказчика.

\section{КОМПЛЕКСНЫЙ И РЕГУЛЯРНЫЙ СЕРВИС ОТ ИЗГОТОВИТЕЛЯ \\ ПОЗВОЛЯЕТ ВЛАДЕЛЬЦАМ ОБОРУДОВАНИЯ \\ МИНИМИЗИРОВАТЬ АВАРИЙНЫЕ СИТУАЦИИ}

- Авария, произошедшая на Саяно-Шушенской ГЭС, по-видимому, заставила российских энергетиков принципиально иначе взглянуть на вопросы сервисного обслуживания?

- Безусловно, после этой аварии взгляд российских энергетиков на сервис изменился. Авария на Саяно-Шушенской ГЭС заставила их осознать уникальность сервиса от завода-изготовителя, задуматься о внедрении долгосрочных сервисных договоров. Комплексный и регулярный сервис от изготовителя позволяет владельцам оборудования реально минимизировать аварийные ситуации, получать все виды сервисных услуг по принципу «одного окна», заблаговременно иметь «пул» запасных частей для конкретного обслуживаемого оборудования. Очень важен и немате- 
риальный аспект такого долговременного сотрудничества. Я имею в виду повышение технической грамотности и квалификации персонала станций, преемственность в обслуживании оборудования.

Что касается нашего сотрудничества с Саяно-Шушенской ГЭС в период восстановления и модернизации станции после аварии, то согласно контракту, заключенному в ноябре 2009г., «Силовые машины» должны были изготовить 10 гидротурбин и 9 гидрогенераторов мощностью по 640 МВт. Все оборудование было изготовлено досрочно и поставлено на станцию к январю 2013 г. В настоящий момент на Саяно-Шушенской ГЭС в работе находятся девять новых гидроагрегатов общей мощностью 5760 МВт. В текущем году были введены в эксплуатацию гидроагрегаты со станционными номерами 3 и 4. Пуск последнего гидроагрегата №2 в соответствии с графиком восстановления станции состоится до конца 2014 года.

«Силовые машины» не только изготовили новое оборудование и модернизировали ту его часть, которая оставалась на станции, но и произвели монтаж, включая шефмонтаж и пусконаладку. Нами также подписан двухлетний сервисный договор с РусГидро об обслуживании во время гарантийного и послегарантийного периода эксплуатации оборудования Саяно-Шушенской ГЭС. Это пилотный проект, который дает право на участие специалистов дирекции по сервису «Силовых машин» во всех производимых
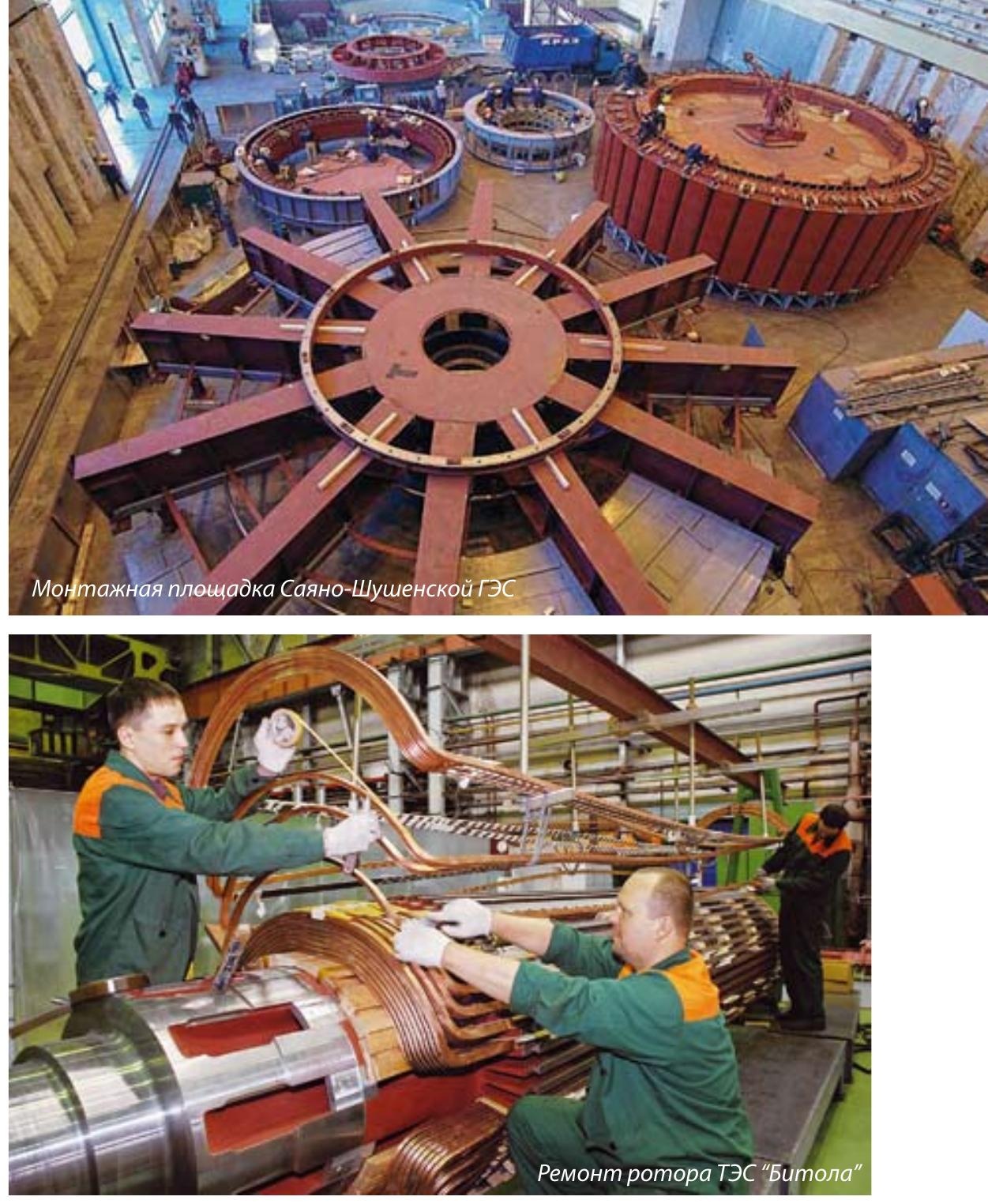
ремонтах установленного оборудования. Мы участвуем в сопровождении как ремонтов турбин, генераторов, систем возбуждения, так и действующих на станции систем управления. В дальнейшем мы по согласованию с РусГидро планируем заключить большой сервисный договор на обслуживание всего оборудования Саяно-Шушенской ГЭС в период его жизненного цикла. Надеемся также, что данная практика будет реализована на всех объектах РусГидро, где работает оборудование «Силовых машин».

\section{ДОЛГОСРОЧНЫЙ СЕРВИС - ЛОГИЧНОЕ ПРОДОЛЖЕНИЕ ЖИЗНЕННОГО ЦИКЛА ОБОРУДОВАНИЯ}

— То есть компания неуклонно продолжает работу по внедрению долгосрочных сервисных договоров?

- Развитие долгосрочного комплексного сервиса от производителя - одно из наших стратегических направлений. Прежде всего потому, что долгосрочный сервис является логичным продолжениемжизненногоцикла производимого оборудования. У нас уже есть опыт оказания таких услуг. Долгосрочные сервисные договоры на 12 лет, которые на сегодняшний день действуют с ТГК-1, предполагают долгосрочное обслуживание парогазовых установок, которые были поставлены и смонтированы «Силовыми машинами» на Первомайской и Южной ТЭЦ. Эксплуатировать газовую машину без регулярного сервиса невозможно, здесь четко расписаны все виды регламентных работ и по обслуживанию, и по замене частей, в первую очередь, работающих при высоких температурах: лопатки, детали камер сгорания - т.е. тех, которые изнашиваются особенно быстро и отказ которых может привести к полному разрушению оборудования.

Однако мы обслуживаем не только газовые и паровые турбины, но и генераторы и АСУ данных блоков. Паровые машины и генераторы мы об- служиваем самостоятельно с нашим шефперсоналом, с возможностями нашего производства и конструкторского бюро.

— Что включает в себя договор долгосрочного сервисного обслуживания?

- Здесь все определяется потребностями заказчика. Впринципелюбой сервисный договор можно оформить как долгосрочный. Это может быть договор на технические консультации, на шеф-инженерное сопровождение. В состав опций может входить и подготовка документации для проведения ремонта и осуществления ремонтных работ, поставка запасных частей. Однако, говоря одолгосрочном сервисе, мы в первую очередь имеем в виду комплексный подход. В таком договоре подробно расписаны объемы регламентных работ, а также действия при внеплановых ремонтах, аварийных ситуациях и так далее. По таким контрактам шире и размер ответственности компании, и гарантии, предоставляемые заказчику.

Все регламентные работы, предусмотренные для того или иного вида оборудования: текущие, средние и капитальные ремонты, замена изношенных узлов и деталей и другие - выполняются в рамках финансиро- 
вания единого долгосрочного договора. Также мы автоматически закрываем при необходимости и все нештатные ситуации, а послевыяснения причин ихвозникновения и определения сферы ответственности всех сторон решаем вопрос о дополнительном финансировании.

\section{ПРИ ПОЛУЧЕНИИ ОПЕРАТИВНОГО ОБСЛУЖИВАНИЯ СНИЖАЮТСЯ ЭКСПЛУАТАЦИОННЫЕ ИЗДЕРЖКИ, ЗА СЧЕТ ИСПОЛЬЗОВАНИЯ «РОДНЫХ» ЗАПЧАСТЕЙ ПОВЫШАЕТСЯ НАДЕЖНОСТЬ ОБОРУДОВАНИЯ, РЕМОНТНЫЕ ПРОГРАММЫ ИДУТ ПО ПЛАНУ}

- Как проводится подобная эксперmuзa?

- Как правило, назначается совместная комиссия, которая проводит расследование и дает заключение. Если есть спорные вопросы, возможно и подключение независимого эксперта.

Особенно хочу подчеркнуть, что в рамках долгосрочного сервисного договора мы не только поддерживаем оборудование в рабочем состоянии, но и даем предложения по его обновлению и модернизации. Сегодня технический прогресс идет ускоренными темпами, причем этими ускоренными темпами развивается как производство основного оборудования, так и производство систем управления, программных продуктов, призванных обеспечить работу станций. Следовательно, новые возможности для улучшения работы и повышения экономичности оборудования появляются практически постоянно. Их нужно отслеживать в комплексе, добиваясь того, чтобы электроэнергия, которую вырабатывает станция, имела невысокую себестоимость. Даже малейший нюанс в работе оборудования при таком подходе может быть решающим.

Все большее число энергетиков это понимают. Появляется и убежденность в том, что деньги, вложенные в сервис, окупаются сторицей, что качество запчастей не менее важно, чем качество нового оборудования.

Преимущества договоров долгосрочного сервиса для заказчика весьма ощутимы. При получении оперативного обслуживания снижаются эксплуатационные издержки, за счет использования «родных» запчастей повышается надежность оборудования, ремонтные программы идут по плану, и, наконец, есть возможность спрогнозировать финансовые вложения в сервис, ведь финансовые условия договора фиксируются на весь период его действия.

Думаю, что вслед за мировой практикой долгосрочного сервиса блоков ПГУ российские компании постепенно перейдут к долгосрочному обслуживанию тепловых электростанций с обычными паровыми блоками. Работаем мы по развитию долгосрочного сервиса и с Интер РАО, и с Газэнергохолдингом, но дальше всего продвинулись в работе с РусГидро.

Замечу, что в Финляндии, например, гидростанции обслуживаются на условиях долгосрочных сервисных договоров.

- Однако пока для российской энергетики долгосрочные комплексные сервисные договоры все же скорее перспектива, нежели реальность сегодняшнего дня. И надеяться на то, что такие договоры станут основой портфеля сервисных контрактов, по-видимому, еще рано...

- Вы правы. Главной составляющей портфеля наших сервисных контрактов остается модернизация. Сегодня в России и странах СНГ свыше $60 \%$ энергетического оборудования исчерпало свой ресурс. В основном это оборудование нашихсамыхмассовыхсерий 200 МВти 300 МВт. «Силовымимашинами» разработаны пакетные предложения по модернизации энергоблоков данных серий с увеличением мощности и повышением КПД. Сформирован комплексный модернизационный пакет на все оборудование, входящее в продуктовую линейку компании: турбины, генераторы, котлы. Предлагаем мы и модернизацию автоматики, замену программных продуктов. Наши комплексные предложения выгодно отличаются от более короткой линейки модернизационных пакетов, которую предлагают наши конкуренты.

Кроме того, мы готовы предоставлять все наши услуги «под ключ». То есть помимо производства оборудования, необходимого для модернизации станций, мы полностью берем на себя и весь процесс его замены, предоставляем услуги по доставке, монтажу, пусконаладке и сдаче заказчику в коммерческую эксплуатацию с подтверждением всех заявленных параметров. Заказчику не нужен набор деталей, ему нужен агрегат, который выдает электроэнергию. А качественно проведенный монтаж и пусконаладка так же важны для эффективной эксплуатации, как и качественное конструирование и производство.

Именно так мы работаем в тепловой энергетике. Завершена модернизация блока № 13 Луганской ТЭС в Украине, работы выполнены «Силовыми машинами» «под ключ», все заявленные параметры подтверждены. Закончен проект модернизации Верхнетагильской ГРЭС, для которой мы поставляли оборудование, производили шефмонтаж, наладку и сдачу оборудования в эксплуатацию. Идут работы на Ириклинской ГРЭС на Южном Урале, где мы осуществляем модернизацию блока 300 МВт.

Завершили модернизацию каскада Вуоксинских ГЭС, включающего две гидроэлектростанции: Лесогорскую и Светогорскую. На Чебоксарской ГЭС идет модернизация турбин и генераторов, на Усть-Илимской ГЭС выполняются работы по замене рабочих колес.

В Казахстане производим замену рабочих колес Усть-Каменогорской ГЭС, в Узбекистане ведется модернизация двух блоков по 300 МВт Сырдарьинской ТЭС. Этот проект хочу отметить особо, именно потому что работы выполняются комплексно: модернизируются турбина, генератор, котел, АСУ. На Ново-Ангренской станции в Узбекистане проводятся модернизация блока $300 \mathrm{MBT}$, замена роторов и генератора. 
Два крупных контракта подписаны в Латвии. Это контракты на модернизацию Плявиньской и Кегумской ГЭС - замена рабочих колес и модернизация генераторов. Нужно сказать, что их мы выиграли в жесткой конкурентной борьбе. Одержать победу позволили уникальные технические решения, которые дали возможность выполнить требования тендера по КПД и цене, а также по весьма сжатым срокам: произвести замену оборудования Кегумской ГЭС нужно между паводками, т. е. за 8 мес., в то время как обычно на подобные работы уходит до года. Изготовление оборудования по этому контракту уже идет, а сами работы на станции запланированы на 2015-2016гг.

- На всех перечисленных Вами станциях изначально стояло оборудование "Силовых машин»?

- В основном да, но мы можем модернизировать и чужое оборудование. На гидростанциях мы уже сегодня готовы предложить заказчику модернизацию любых турбин, замену рабочих колес, модернизацию генераторов. Также в настоящее время наше конструкторское бюро заканчивает проектирование пакетов модернизаций турбин производства Уральского турбинного завода, харьковского турбинного завода «Турбоатом» и генераторов харьковского завода «ЭлектроТяжМаш» мощностью 200 МВт и 300 МВт.

- Насколько широка география ваших планов?

- Если взять карту мира, то мы не найдем оборудования «Силовых машин» разве что в Австралии, Японии и Новой Зеландии. Традиционно наша компания широко представлена в Восточной Европе, на Балканах. Это и Македония, и Сербия, и Хорватия, и Босния, и Болгария, и Греция.

В Финляндии мы оказываем сервисные услуги на многих тепловых и гидростанциях, оснащенных нашим оборудованием. Осуществляется поставка запчастей для ТЭС «Топпила» и «Тахкопуотто», ГЭС «Альхольма», подписан контракт на модернизацию генератора на третьем энергоблоке ГЭС «Нуойя».

На Ближнем Востоке наше оборудование установлено в Иране, Ираке, Пакистане. Действуют постоянные договоры на поставку запасных частей для ТЭС «Горазал» В Бангладеш, а также индийских станций - ТЭС «Бокаро» и «Сипат», ГЭС «Балимела».

В Африке оснащенные нашим оборудованием станции находятся в Египте (ГЭС «Асуан»), Алжире (ТЭС «Жижель»), Марокко (ТЭС «Джерада»), Анголе (ГЭС «Капанда»). В Южной Америке - это Аргентина, Бразилия, Чили, Мексика, Колумбия. Наше оборудование есть даже в Канаде и США, где с середины 1990-хгг. работают две гидроэлектростанции. Туда тоже рассчитываем войти с нашими сервисными услугами.

- Нет ли у дирекции по сервису планов открытия представительств, подобных представительствам сбытовой дирекции?

- На сегодняшний день у нас есть представительства двух видов. Во-первых, те, которые мы организуем на период исполнения заказов. Например, временное представительство работало в Македонии, где мы проводили модернизацию блоков 200 МВт на ТЭС «Битола», в 2013 г. были созданы такие подразделения в Латвии и Украине.

Представительства второго типа создаются в определенных регионах для продвижения сервисных услуг нашей компании. Таковые открыты в Узбекистане, Аргентине, Чили, Сербии. Есть и планы по открытию новых — в Казахстане и Беларуси, а также в российских регионах: на Урале и Дальнем Востоке, в Красноярском крае.

Основная задача создания такихпредставительств или сервисныхцентров заключается в том, чтобы объединить наши усилия с усилиями региональных ремонтных компаний. Рынок сервиса, в том числе и внутрироссийский, имеет огромный потенциал для роста. Сегодня основные заказчики нашего оборудования занимаются сервисом самостоятельно, имея собственные сервисные подразделения или сервисные дочерние компании. Однако их персонал неуклонно меняется, растет процент молодых специалистов, которым необходимыдополнительное образование, дополнительный опыт и навыки в проведении ремонтов. Мы хотим объединить наши возможности с возможностями сервисных компаний и совместно оказывать услуги, повышая их качество.

В частности, региональные компании мы можем привлекать в качестве субподрядчиков для выполнения под нашим контролем как демонтажа старого, так и монтажа нового оборудования. Такое сотрудничество предполагает комплексноевзаимодействие: оказание услуг по обучению персонала, услуги по совместному проведению ремонтов, проведение модернизаций с привлечением регионального ремонтного персонала.

Антонина КРИЩЕНКО

По материалам журнала «Мегаватm» №3-2014 (клиентского издания ОАО «Силовые машины»)

UDC 621.31.004.67 @ I.S. Makarov, 2014

ISSN 0041-5790 • UGOL №11-2014/1064/

Title

COMPLEX SERVICE FOR THE LONG HAUL

Author

Makarov I.S.

Authors' Information

Makarov I.S., director of board on "Power machines" service, Saint Petersburg, Russia

\section{Abstract}

The more technically developed becomes the energy equipment, the more important is its quality maintenance. That is why all the machine building leaders actively develop servicing area and the share of service contracts in the total amount of orders becomes really significant. Igor Makarov, Head of service directorate, describes new types of services provided by the "Power Machines" company. The interview is recorded by Antonina Kryschenko.

\section{Keywords}

"Power Machines", services, hydro power plant, water turbine. 


\section{Комментарий к пункту 425}

\section{новых «Правил безопасности в угольных шахтах»}

\author{
ЮРОВ Константин Михайлович \\ Стариий инженер $3 A O$ «ЗМ Россия»
}

В настоящей статье рассмотрены вопросы применения починочных комплектов 3 для соединения и ремонта кабеля в свете новых требований Правил безопасности в угольных шахтах.

Ключевые слова: Правила безопасности в угольных шахтах, кабель, бронированный кабель, гибкий кабель, починочный комплект, компаунд, трубки холодной усадки.

Согласно приказу Ростехнадзора от 19.11.2013 №550 «Об утверждении Федеральных норм и правил в области промышленной безопасности «Правила безопасности в угольных шахтах» (зарегистрирован в Минюсте России 31.12.2013 №30961), в нынешнем году в силу вступили новые Правила безопасности (далее ПБ).

В этих правилах, в частности, пункт 425 гласит дословно следующее:

... 425. Допускается соединение и ремонт (восстановление) гибких и бронированных кабелей в шахтах с помощью горячей вулканизации и комплектов починочных материалов из компаундов и трубок холодной усадки...

Настоящий пункт пришел на смену пункту 506 прежних ПБ 05-618-03 от 5 июня 2003 г.

В этом пункте, в частности, дословно значилось следующее:

... Допускается соединение и ремонт (восстановление) гибких и бронированных кабелей в шахтах с помощью пастообразных или липких ленточных и других полимерных изоляционных материалов в порядке, установленном Госгортехнадзором России...
Как мы видим, в новых правилах отсутствует понятие пастообразных, липких ленточных и других полимерных материалов, а также упоминание о порядке, устанавливаемом Госгортехнадзором России.

Зато появляется четкая ссылка на однозначно трактуемые технологии компаундов и трубок холодной усадки, а также появляется важное слово - комплект.

Что же и почему изменилось? Во главе угла, как всегда, стоит вопрос безопасности. В связи с тем, что понятие пастообразных, липких ленточных, равно как и других полимерных материалов, является крайне расплывчатым, становилось практически невозможно разграничить временный или капитальный ремонт кабеля. Плюс применение этих материалов не в составе комплекта с четко прописанной пошаговой инструкцией, а вразнобой и на свое усмотрение, накладывало дополнительную ответственность, как на непосредственного исполнителя работ, так и на проверяющие органы. В конечном счете это приводило к снижению безопасности при эксплуатации кабеля в угольной шахте.

В новом пункте как технологии, так и комплектность изделий прописаны совершенно конкретно. И теперь двоякое толкование требований ПБ исключено.

Другой вопрос: готов ли к этому рынок специализированной для угольных шахт кабельной арматуры? Компания ЗМ дает утвердительный ответ на этот вопрос.

Вот уже восемь лет компания 3М разрабатывает для угольного рынка России решения по ремонту и монтажу кабеля на основе комплектов починочных материалов. При этом основными технологиями, рекомендуемыми специалистами 3М для применения в угольных шахтах, являются компаунды и изделия холодной усадки.

В своей работе мы традиционно разграничиваем кабель на бронированный и гибкий. Решения по этим типам кабеля с описанием применяемых технологий представлены в табл. 1, 2 и проиллюстрированы на рисунке.

Таблица 1

\section{Комплекты починочных материалов для соединения и ремонта бронированного кабеля}

\begin{tabular}{|c|c|c|c|c|}
\hline $\begin{array}{c}\text { Наименование } \\
\text { починочного комплекта }\end{array}$ & Назначение & Тип кабеля & $\begin{array}{c}\text { Сечение } \\
\text { основных жил, мм² }\end{array}$ & Технология \\
\hline 92-A 615 & Соединение кабеля & КШВЭБбШв 6 кВ и его аналоги & $3 \times 16-3 \times 120^{*}$ & Заливной компаунд \\
\hline 92-OT 411-3 & Соединение кабеля & СБГ, ЦСБ 6 кВ и его аналоги & $3 \times 16-3 \times 120$ & Заливной компаунд \\
\hline $92-$ OT $421-3$ & Соединение кабеля & СБГ, ЦСБ 6 кВ и его аналоги & $3 \times 120-3 \times 240$ & Заливной компаунд \\
\hline 92-OT RK-1 & Ремонт оболочки & СБГ, ЦСБ 6 кВ и его аналоги & $3 \times 16-3 \times 240$ & Заливной компаунд \\
\hline
\end{tabular}

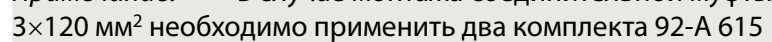

Таблица 2

Комплекты починочных материалов для соединения и ремонта гибкого кабеля

\begin{tabular}{|c|c|c|c|c|}
\hline $\begin{array}{c}\text { Наименование } \\
\text { починочного } \\
\text { комплекта }\end{array}$ & Назначение & Тип кабеля & 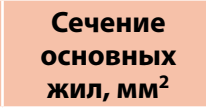 & Технология \\
\hline 92-AV 524 & Соединение и ремонт кабеля & КГЭ-Н 6 кВ и его аналоги & $3 \times 16-3 \times 50$ & Заливной компаунд \\
\hline 92-AV 534 & Соединение и ремонт кабеля & КГЭ-Н 6 кВ и его аналоги & $3 \times 50-3 \times 150$ & Заливной компаунд \\
\hline 92-AV 160 & Соединение и ремонт кабеля & КГЭШ 1,14 кВ или 3,3 кВ и его аналоги & $3 \times 16-3 \times 35$ & Заливной компаунд \\
\hline 92-AV 170 & Соединение и ремонт кабеля & КГЭШ 1,14 кВ или 3,3 кВ и его аналоги & $3 \times 50-3 \times 95$ & Заливной компаунд \\
\hline 3121 & Соединение кабеля & КГЭС 1,14 кВ и его аналоги & $3 \times 16-3 \times 19$ & Холодная усадка \\
\hline 3123 & Соединение кабеля & КГЭ-Н 6кВ, КГЭШ 1,14 кВ или 3,3 и их аналоги & $3 \times 16-3 \times 95$ & Холодная усадка \\
\hline
\end{tabular}




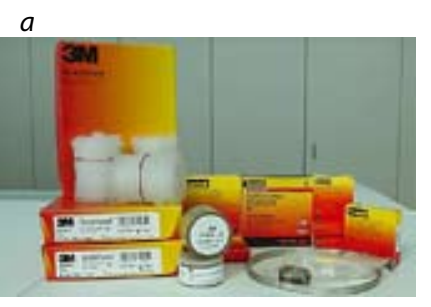

2

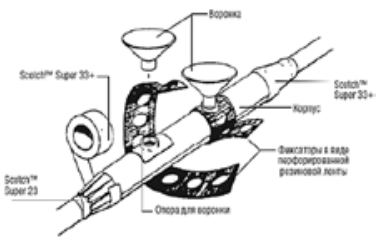
Solde:

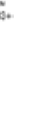

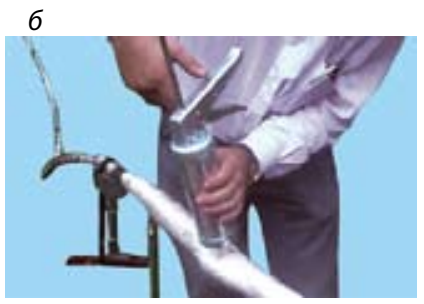

$\partial$

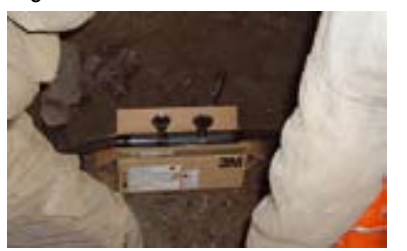

Более подробно об этих решениях и технологиях можно прочитать в статьях, опубликованных в журнале «Уголь» $[1,2,3,4,5]$.

Следует отметить, что за долгие годы эксплуатации в угольной промышленности России электроизоляционные технологии 3М, а также комплекты на их основе показали свою высокую работоспособность и позволили быстро решить проблему оперативного монтажа и ремонта как бронированного, так и гибкого экранированного кабеля, эксплуатируемого в угольных шахтах. Эти комплекты, равно как и другие продукты 3М, стали отличным подспорьем для работников угольных шахт, позволив облегчить и обезопасить труд человека, резко снизить простои техники и увеличить добычуугля.

Если по какой-то причине Вы или Ваше предприятие еще не применяет подобных решений, но вы желаете опробовать их в своей работе, свяжитесь с нашими представителями или партнерами в вашем или соседнем регионе и по-

UDC 622.8:621.315.687.1

(c) K.M. Yurov, 2014

ISSN 0041-5790 • UGOL №11-2014/1064/

Title

COMMENTARY TO THE ITEM 425

OF NEW "RULES OF SAFETY IN COAL MINES"

\section{Author}

Yurov K.M.

\section{Authors' Information}

Yurov K.M., chief engineer of "3M Russia" CC, Moscow, Russia,

tel.: +7 (495) 7847474

\section{Annotation}

This paper describes the application of $3 \mathrm{M}$ fixing kits for connection and repairing of the cable according to new safety requirements in coal mines.

\section{Key words}

Safety Rules in the Coal Mines, Cable, Shielded Cable, Flexible Cable, Fixing Kit, Compound, Cold Shrink Tubes.

\section{References}

1. Yurov K.M. Solving the problem of the termination excavator cable breakdown of CFS type. [Reshenie problem proboya kontsevoy zadelki ekskavatornogo kabelia tipa KGE] Ugol-Coal, 2014, №3, S.46-47.

2. Yurov K.M. Solutions for connecting stationary armored cable with PVC insulation in the mine. [Reshenie dlia soedineniya statsionarnogo bronirovannogo kabelia s PVH-izoliatsiey v shahte] Ugol-Coal, 2014, №4, S.8-9.

3. Yurov K.M. On-line repair of the flexible cable in coal lava [Operativniy remont gibkogo kabelia $v$ ugolnoy lave] // Ugol-Coal, 2014, №5, S.36-37.

4. Yurov K.M. Fast connection of flexible shielded cable of CFS CFSM types and their analogues using cold shrink $3 \mathrm{M}$ couplings. [Bystroe soedinenie gibkogo ekranirovannogo kabelia tipov KGE, KGESH I ih analogov pri pomoshchi holodnousagivaemykh muft 3M] Ugol-Coal, 2014, №8, S.72-73.

5. Yurov K.M. On-line repair of flexible shielded of CFS CFSM types and their analogues using tape $3 \mathrm{M}$ materials and components. [Operativniy remont gibkogo ekranirovannogo kabelia tipov KGE, KGESH i ih analogov pri pomoshchi lentochnykh materialov I kompleksov 3M] Ugol-Coal, 2014, №9, S.52-53.

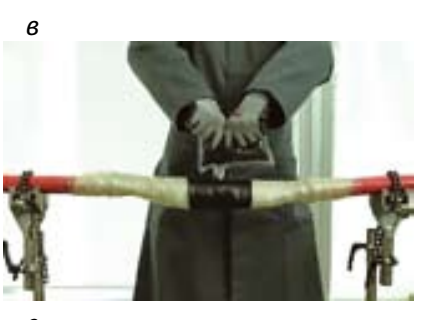

Применение комплектов починочных материалов 3M: а - внешний вид комплекта починочных материалов; б-комплект 92-ОТ 411-3; в - комплект 92-А 615; г - монтаж корпуса гибкой заливной муфты; e д - комплект 92-AV 170; е - комплект 3121

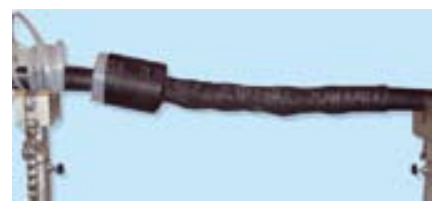

лучите от них высококачественную поддержку в вопросах применения электроизоляционных материалов 3М.

\section{Список литературы}

1. Юров К. М. Решение проблемы пробоя концевой заделки экскаваторного кабеля типа КГЭ // Уголь. 2014. №3. С. 46-47.

2. Юров К.М. Решение для соединения стационарного бронированного кабеля с ПВХ-изоляцией в шахте // Уголь. 2014. №4. C. 8-9.

3. Юров К. М. Оперативный ремонт гибкого кабеля в угольной лаве // Уголь. 2014. №5. С. 36-37

4. Юров К. М. Быстрое соединение гибкого экранированного кабеля типов КГЭ, КГЭШ и их аналогов при помощи холодноусаживаемых муфт 3М // Уголь. 2014. №8. С. 72-73.

5. Юров К. М. Оперативный ремонт гибкого экранированного кабеля типов КГЭ, КГЭШ и их аналогов при помощи ленточных материалов и комплектов 3М // Уголь. 2014. №9. С. 52-53.

\section{3М Россия}

121614, Москва,

ул. Крылатская, д. 17, стр. 3,

Бизнес-парк «Крылатские холмы»

Тел.: +7 (495) 7847474

www. 3mrussia.ru/Mining

www. 3MElectro.ru

Клиентский центр

в Санкт-Петербурге

192029, Санкт-Петербург,

пр. Обуховской обороны,

д. 70, корп. 3/А, 5-й эт.

Бизнес-центр «Фидель»

Тел.: +7 (812) 3366222

Клиентский центр в Екатеринбурге

620014, г. Екатеринбург, ул. Бориса Ельцина, д. 1А,

БЦ «Президент», 11-й этаж

Тел.: +7 (343) 228-22-88; +7 (343) 228-22-99

Региональные представители -

специалисты по предприятиям горнодобывающей индустрии и металлургии:

Евгений Дремин

г. Кемерово

Регион: Кузбасс,

Кемеровская обл.

Моб. тел.: +7 (913) 407-46-35

Алексей Красноперов

г. Екатеринбург

Регион: Северный Урал

Моб. тел.: +7 (912) 610-20-15

\section{Михаил Попков}

Санкт-Петербург

Регион: Архангельская обл., Республика Коми, Санкт-Петербург

Моб. тел.: +7 (921) 849-97-11

\section{Андрей Зоммер}

г. Красноярск

Регион:

Сибирь и Дальний Восток

Моб. тел.: +7 (983) 077-53-61

\section{Сергей Пшеничный}

г. Челябинск

Регион:

Башкирия, Южный Урал

Моб. тел.: +7 (912) 893-23-71 


\section{В Кузбассе открылся цех \\ по утилизации отработанных самоспасателей}

В Управлении дегазации и утилизации метана ОАО «СУЭК-Кузбасс» начал работу цех по утилизации шахтных самоспасателей.

Цех организован в рамках инвестиционной программы по созданию собственного производства горношахтного оборудования. На этот вид деятельности предприятие получило лицензию Федеральной службы по надзору в сфере природопользования, разрешения на утилизацию и технологические регламенты утилизации самоспасателей, согласованные с заводами-изготовителями.

Новый цех расположился на территории технологического комплекса шахты «Имени С.М. Кирова». В нем производят разборку отработанных и списанных самоспасателей, отработанных патронов к учебным приборам, осуществляют обезвреживание кислородосодержащего продукта.

Утилизация каждого самоспасателя на собственной базе в сравнении с ближайшим рыночным подрядчиком обходится на 50-80 руб. дешевле.

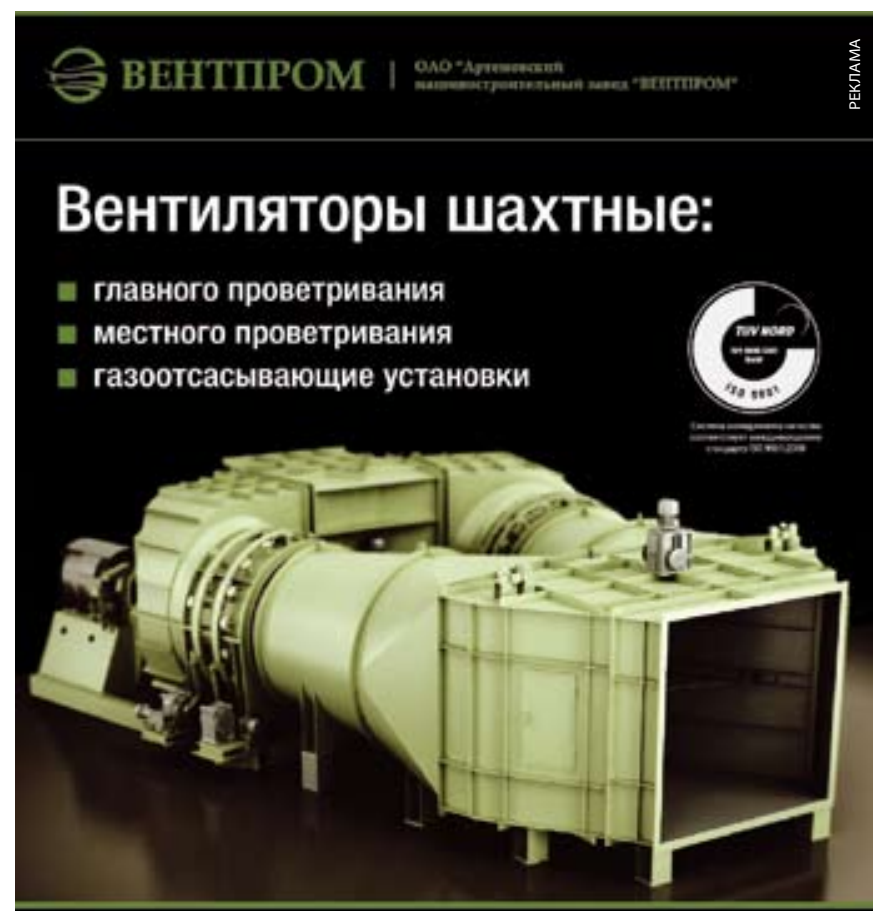

Свердловская область, г. Артемовский, ул. Садовая, 12

Ten: $\quad(34363) 58-112,58-105,58-100$

कance $\quad(34363) 58-158$

E-mak ventprom@ventprom.com

webs www.ventprom.com

Представительство в г. Новокузнецке:

Ten: $\quad+7$ 913-136-37-75, +7 923-622-99-73

6-mak ilnar_ventprom@mail.ru
Мощность производства рассчитана на утилизацию 48 тыс. самоспасателей в год. Потребности компании «СУЭК-Кузбасс» 6,5 тыс. Поэтому Управление уже заключило договоры на утилизацию отслуживших
СИБИРСКАЯ УГОЛЬНАЯ ЭНЕРГЕТИЧЕСКАЯ КОМПАНИЯ свой срок учебных и рабочих средств индивидуальной защиты с предприятиями на территории Кузбасса и за его границами.

Наша справка

ОАО «Сибирская угольная энергетическая компания» (СУЭК) - крупнейшее в России угольное объединение по объему добычи. Компания обеспечивает около $30 \%$ поставок угля на внутреннем рынке и примерно $25 \%$ российского экспорта энергетического угля. Филиалы и дочерние предприятия СУЭК расположены в Забайкальском, Красноярском, Приморском и Хабаровском краях, Кемеровской области, в Бурятии и Хакасии и Мурманской области.

Около трети от общего объема угледобычи СУЭК обеспечивает ленинск-кузнецкое подразделение компании ОАО «СУЭК-Кузбасс». В состав компании входят девять шахт, три угольных разреза, три обогатительных фабрики и 16 вспомогательных предприятий.

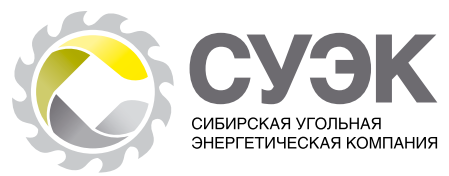

Бригада Василия Ватокина шахты «Имени 7 Ноября»

\section{добыла три миллиона тонн угля}

5 сентября 2014 г. бригада Василия Ватокина участка №1 шахты «Имени 7 Ноября» второй в ОАО «СУЭК-Кузбасс» добыла 3 млн т угля с начала года из одной лавы.

Первой в компании 3 млн т с начала года выдала бригада Героя Труда России Владимира Мельника шахты «Котинская» ОАО «СУЭК-Кузбасс. Рекорд компании и угольной отрасли в целом установлен 18 августа.

Бригада Василия Ватокина начала отрабатывать лаву в феврале, через три месяца она преодолела миллионный рубеж, через семь месяцев коллектив выдал на-гора уже три миллиона тонн угля.

Вынимаемая мощность отрабатываемого пласта лавы №1380 на шахте «Имени 7 Ноября» составляет 4,6 м. Забой оборудован комбайном SL-500, лавным конвейером SH PF 4/1032 (Германия) и 166 секциями крепи «Тагор 24/50» (Польша), оснащенными многофункциональной электрогидравлической системой управления фирмы MARCO (Германия) . 


\section{Повышение эффективности управления}

\section{резервами роста производительности труда на угледобывающих предприятиях}

\author{
ПопОВ Владимир Николаевич \\ Доктор экон. наук, профессор (ЦНИЭИуголь), \\ Москва, Россия, тел.: +7 (495) 777-18-71

\section{ГРИБИН Юрий Георгиевич} \\ Доктор экон. наук, профессор (ЦНИЭИуголь), \\ Москва, Россия
}

\section{ГАРКАВЕНКО Андрей Николаевич \\ Доктор экон. наук (ЦНИЭИуголь) \\ Москва, Россия}

Статья посвящена научной и практической задаче повышения эффективности управления резервами роста производительности труда на угледобывающих предприятиях. Ключевые слова: управление, производительность, качество, эффективность, результативность труда, резервы.

В настоящих условиях модернизации и интенсификации трудоемкого угледобывающего производства особую значимость приобретает научная и практическая задача существенного повышения производительности труда - важнейшего показателя, характеризующего его эффективность и качество.

В процессе исследования была сформированапроцедура повышения эффективности управления резервами роста производительности труда на угледобывающих предприятиях. На практике экономическая сущность изыскания резервов роста производительности труда и повышения эффективности угледобывающего производства состоит в наиболее рациональном использовании потенциальных возможностей увеличения выпуска высококачественной продукции, востребованной на внутреннем и внешних рынках, всемерной экономии материальных, трудовых и финансовых ресурсов, снижения трудоемкости работ и себестоимости продукции.

На рис. 1 приведена рекомендуемая процедура выявления внутрипроизводственных резервов роста производительности труда на угледобывающих предприятиях.

Межотраслевые и отраслевые исследования показали, что резервы роста производительности труда могут быть систематизированы по следующим признакам: пространственному (внутрипроизводственные, отраслевые, региональные, общегосударственные); временному (неиспользованные, текущие, перспективные); постадийному (предпроизводственные, производственные, эксплуатационные); мотивационному (виды стимулов, категории персо- нала, параметры стимулирования); природному (экстенсивные, интенсивные); проявленческому (явные, скрытые).

Для повышения эффективности управления резервами роста производительности труда на угледобывающих предприятиях следует руководствоваться системой принципов: научности; комплексности; системности; комплектности; экономичности; оперативности; массовости; эффективности.

В числе наиболее распространенных методов изыскания и определения величины резервов роста производительности труда могут использоваться методы, широко применяемые в межотраслевой и отраслевой практике [1, 2, 3]: прямого счета; аналитического сравнения; факторного анализа; корреляции; математического регулирования; расчетно-конструктивных оценок и другие, позволяющие повысить эффективность управления данным процессом. Например, при использовании метода расчетно-конструктивных оценок зависимость для определения резервов роста производительности труда с целью повышения эффективности управления может быть представлена в следующем виде:

$$
P_{n m}=\frac{a+8}{c-\kappa+n}-\frac{a}{c},
$$

где: $P_{n m}$ резервы роста производительности труда, $a-$ фактический объем валовой продукции; в - резервы увеличения валовой продукции; $c$ - фактические затраты труда на выпуск валовой продукции; $\kappa$ - резервы сокращения затрат труда; $n$ - дополнительные затраты труда, необходимые для выпуска продукции.

Обеспечить эффективность управления резервами роста производительности труда на угледобывающих предприятиях в современных условиях возможно в том случае, если делать ставку не только на увеличение объемов угольной продукции, а добиваться, прежде всего, улучшения качественных показателей по всем основным аспектам деятельности, обеспечения режима всемерной экономии ресурсов, повышения творческой инициативы и активности, ускорения научно-технического развития производства на основе его модернизации, внедрения инноваций и новшеств во все сферы производства и труда.

Повышение качественных показателей труда, обусловливающих рост его производительности, предполагает прежде всего выпуск высококачественной, конкурентоспособной продукции, максимально рациональное использование материальных, трудовых, финансовых, информационных ресурсов, снижение производственных затрат при выпуске продукции, обеспечение всемерного роста уровня квалификации персонала, его профессионального мастерства, широкое внедрение прогрессивных систем 


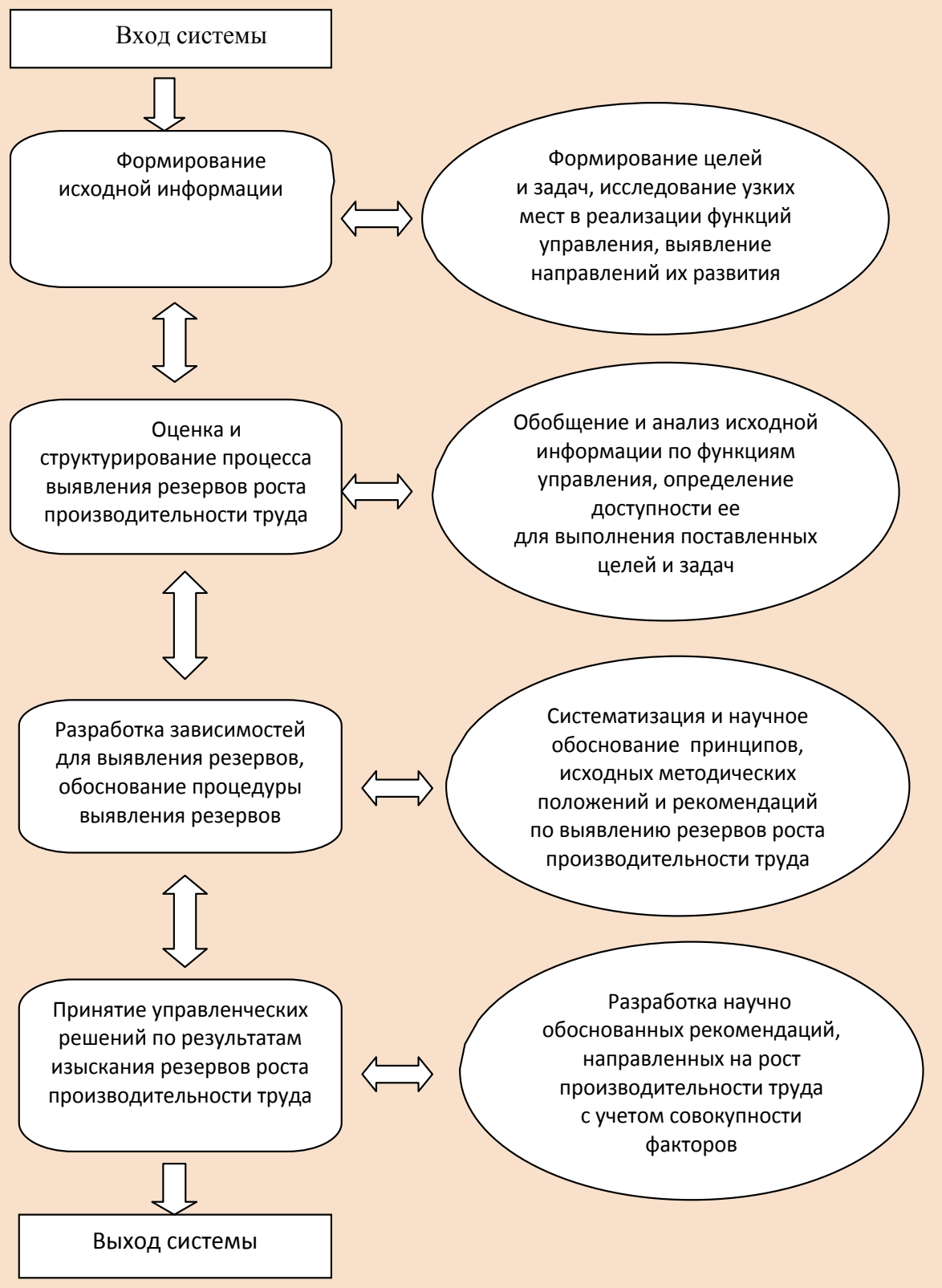

Puс. 1. Процедура выявления внутрипроизводственных резервов роста производительности труда на угледобывающих предприятиях

Качество использования горнотранспортного оборудования на угледобывающем предприятии может характеризоваться, например, интегральным коэффициентом $\left(K_{n o}\right)$, определяемым по формуле:

$$
K_{n o}=K_{M} \cdot K_{s} \text {, }
$$

где: $K_{м}-$ коэффициент использования горнотранспортного оборудования по мощности; $K_{\varepsilon}$ - коэффициент использования горнотранспортного оборудования по времени.

Повышению качества и эффективности труда на угледобывающих предприятиях, а также вскрытию внутрипроизводственных резервов должен способствовать системный факторный анализ роста производительности труда, принципы которого были подробно освещены нами в статье [1].

Рекомендованная в этой работе методика оценки резервов роста производительности труда предполагает изучение следующих факторов:

- технические и технологические (внедрение новой высокопроизводительной техники, механизация отдельных рабочих процессов и автоматизация управления машинами и установками, сокращение ручного труда, рост производительности горнотранспортного оборудования, изменение структуры производства);

— концентрация производства (нагрузка на предприятие);

- ввод в эксплуатацию новых и реконструкция действующих структурных подразделений, предприятий (повышение технологического и организационного уровня производства за счет применения более современной техники и технологии, использования

мотивации, материального стимулирования и оплаты труда, в полной мере соответствующих конкретным условиям производства, обеспечение всех участков угледобывающего производства высококачественными профессиональными стандартами для основных категорий персонала, применение научно обоснованной системы оценки качества труда, включая его сложность, тяжесть и условия, а также своевременную и действенную аттестацию и рационализацию рабочих мест, использование на практике современных форм и методов подготовки персонала, соответствующих требованиям рыночной экономики.

На угледобывающих предприятиях по опыту зарубежных компаний должны получить широкое распространение формирование и реализация конкретных научно-технических и социально-экономических программ, предусматривающих действенный набор мероприятий, обеспечивающих, прежде всего, повышение качества производства и труда, улучшение использования рабочего времени и горнотранспортного оборудования (по мощности и во времени). эффективных вспомогательных служб);

- организационные (сокращение потерь рабочего времени за счет снижения заболеваемости, целодневных простоев, невыходов работников);

— природные (внедрение мероприятий по улучшению условий производства, труда, техники безопасности, охраны окружающей среды).

Следует отметить, что в современных условиях организации производства и труда в процессе системного анализа эффективность, качество, производительность и результативность деятельности целесообразно оценивать с учетом как живого, так и прошлого труда.

В связи с этим производительность труда, характеризующая эффективность деятельности в широком смысле этого понятия $\left(\Pi_{m}{ }^{o}\right)$, может определяться исходя из следующего выражения:

$$
\Pi_{m}^{o}=\frac{V_{n}}{\sum_{i=1}^{m} \sum_{j=1}^{n} V_{i j}},
$$


где: $V_{n}$ - объем продукции, произведенной за рассматриваемый период времени; $V_{i j}$ - суммарный объем всех видов ресурсов, израсходованных за рассматриваемый период времени; $m$ - количество используемых ресурсов; $n$ - число видов затрат по каждому ресурсу.

В число суммарного объема израсходованных за рассматриваемый период времени ресурсов должны входить затраты: материалов, труда, энергии, финансов, информации, амортизационные отчисление и др. Поскольку объем произведенной продукции и суммарные затраты всех видов ресурсов, израсходованных на ее получение, выражаются в денежном измерении производительность принимает в этом случае форму коэффициента эффективности, характеризующего в известной степени качество труда.

Исследования показали, что в условиях рыночных отношений подэффективностью труда на угледобывающих предприятиях принято понимать соотношение результативности труда и затрат, произведенных для их достижения. Иными словами, речь должна идти о поиске наиболее рациональных управленческих решений во всех сферах деятельности, направленных на достижение оптимальных результатов при сокращении затрат ресурсов на их достижение.
Если стратегия решения этой задачи предполагает выявление рациональных направлений повышения эффективности труда на основе комплексного использования всех видов ресурсов угледобывающего предприятия, то тактика должна предусматривать разработку конкретных мероприятий по выявлению и использованию резервов роста производительности и эффективности труда на основе всемерного уменьшения нецелесообразных затрат.

На рис. 2 приведена рекомендуемая принципиальная схема, раскрывающая основной круг понятий, связанных с эффективностью и качеством труда в условиях рыночных отношений, разработанная на основе обобщения межотраслевого и отраслевого опыта [1, 2, 3].

Из приведенной схемы видно, что если показатели производительности и эффективности определяют количественное соотношение результатов работы и затрат на ее выполнение, то качество труда должно комплексно характеризовать качественную их основу. Следует отметить, что на практике понятие качества труда в настоящее время наиболее часто отражает только сложность, тяжесть и условия труда, то есть характеристики, используемые при проектировании заработной платы.

Оценка эффективности труда на угледобывающем предприятии, основанная на стоимости объемов выполненных работ с учетом качества и затрат ресурсов на их достижение, необходима прежде всего для внутрипроизводственного анализа и формирования организационно-технических мероприятий, позволяющих выявлять резервы роста производительности и качества труда.

Следует отметить, что управление резервами роста производительности труда может осуществляться в условиях рыночных отношений на угледобывающих предприятиях по: целям (целеполагание); результатам; потребностям и интересам; основе активизации деятельности персонала.

Межотраслевые и отраслевые исследования показывают, что основу технологии управления по целям должен составлять бизнес-план, который следует разрабатывать как для предприятия в целом, так и для каждого работника. Это предполагает формирование и внедрение целевого, программно-целевого или регламентированного управления. Не менее известной является технология управления по результатам, базирующаяся на функции координации факторов внешней и внутренней среды. Она предполагает анализ текущей информации, проведение социологических опросов, определение научных задач и разработку предложений по уточнению управленческих решений, создание информационной базы для
Рис. 2. Рекомендуемая структурная схема, характеризующая основной круг показателей результативности, эфректтивности и качества труда на угледобывающем предприятии 
принятия решений по изысканию резервов роста производительности труда.

Технология управления резервами производительности труда на основе учета потребностей и интересов должна базироваться на материальном стимулировании и мотивации деятельности с учетом групповых и индивидуальных особенностей организации труда. Эта теория имеет большое практическое значение при управлении резервами роста производительности труда на основе повышения эффективности деятельности всех категорий персонала.

Анализ показывает, что в современных условиях угледобывающего производства существенным аспектом совершенствования планирования трудовых показателей и в частности изыскания резервов роста производительности труда, должно являться качественное и системное формирование бизнес-планов, увязанных со всеми технико-технологическими, производственными и социальноэкономическими подсистемами. При этом качество их в значительной мере зависит от научной обоснованности норм и нормативов в области использования техники и оборудования по мощности и во времени; экономии всех видов ресурсов; всемерного снижения затрат труда.

В современных условиях управления резервами роста производительности труда весьма значима функция «мотивация - материальное стимулирование» деятельности. На практике система материального стимулирования в условиях рыночных отношений регулируется отраслевыми и региональными (тарифными) соглашениями, а также коллективными договорами. Она базируется на таких общепризнанных подсистемах, как: тарифные условия оплаты труда; надбавки и доплаты; формы и системы оплаты; текущее премирование; специальные системы единовременного поощрения, премирования и вознаграждения; формирование средств на оплату труда; районное регулирование заработной платы; оценка эффективности организации стимулирования и мотивации.

Исследования показывают, что в числе важнейших направлений изыскания резервов роста производительнос- ти труда на основе более действенной реализации функции «материальное стимулирование» следует отметить:

- формирование на угледобывающих предприятиях профессиональных стандартов;

— научно обоснованную взаимоувязку тарифных условий оплаты труда с его качественными характеристиками — квалификацией, сложностью, тяжестью, условиями, результативностью и эффективностью;

- рациональную и действенную дифференциацию тарифных ставок и должностных окладов сучетом нормативных параметров и результатов деятельности, в частности уровня освоения нормативных нагрузок на горнотранспортное оборудование;

- создание методических рекомендаций, позволяющих обеспечивать единый научный подход к разработке и установлению уровня тарифных условий оплаты труда в рамках акционерного общества, региона;

- рационализация выбора форм и систем оплаты труда, в частности систем премирования и поощрения на рабочих местах с учетом конкретных условий, целей и задач деятельности.

Рассмотренные выше теоретические аспекты, характеризующие методические положения повышения эффективности управления резервами роста производительности труда на угледобывающих предприятиях, могут использоваться при формировании программ и мероприятий, направленных на повышение качества и результативности деятельности персонала.

\section{Список литературы}

1. Грибин Ю. Г., Гаркавенко А. Н., Кузнецова Г.А. О резервах повышения производительности труда — важнейшего показателя эффективности угледобывающего производства в условиях его модернизации // Уголь. 2010. №6. С. 53-56.

2. Слезингер Г.Э. Труд в условиях рыночной экономики. М.: Институт труда, 1996. 335 с.

3. Савицкая Г.В. Анализ хозяйственной деятельности предприятия. Минск: Новое знание, 1999. 683 с.

Title

INCREASING MANAGEMENT EFFICIENCY OF THE LABOR PRODUCTIVITY GROWTH RESERVES AT COAL MINES

\section{Authors}

Popov V.N., Gribin Y.G., Garkavenko A.N.

\section{Authors' Information}

Popov V.N., Doctor of Economics, professor (Scientific-research institute of economics and scientific-technical information of coal industry Itd), Moscow, Russia, tel.: + 7 (495) 777-18-71

Gribin Y.G., Doctor of Economics, професcop (Central scientific-research institute of economics and scientific-technical information of coal industry), Moscow, Russia

Garkavenko A.N., Doctor of Economics (Central scientific-research institute of economics and scientific-technical information of coal industry), Moscow, Russia

\section{Abstract}

The article describes scientific and practical problems of increasing management efficiency of productivity growth reserves at coal mines.

\section{Keywords}

Management, Productivity, Quality, Efficiency, Labor Effectiveness, Reserves.

\section{References}

1. Gribin Y.G., Garkavenko A.N. and Kuznetsov G.A. About the reserves for increasing productivity, important measures of coal production in the context of its modernization. [O rezervah povishenia proizvoditelnosti truda - vazhneyshego pokazatelia effektivnosti ugliedobivaushchego proizvodstva $v$ usloviah ego modernizatsii] Ugol-Coal, 2010, №6, S.53-56.

2. Slezinger G.E. Labor in the market economy. [Trud $v$ usloviah rynochnoy ekonomiki] Moscow, Institute of Labour, 1996, 335 p.

3. Savitskaya G.V. Analysis of the company business activity. [Analiz khoziaystvennoy deyatelnosti predriyatia] Minsk, Novoe znanie - New knowledge, $1999,683 \mathrm{p}$. 


\section{0 функционале заместителя директора}

предприятия по производству

В статье представлены результаты аналитико-моделирующего семинара, посвященного проработке функционала заместителя директора по производству предприятий угледобывающего комплекса ОАО «СУЭК».

Ключевые слова: функционал, ритмичность производства, технологичность, эффективность и безопасность производства.

\section{С 29.09 по 03.10.2014 в НИИОГР был} проведен аналитико-моделирующий семинар, направленный на проработку функционала заместителя директора по производству. В его работе приняли участие 15 заместителей директоров по производству предприятий ОАО «СУЭК», а также группа линейных руководителей и специалистов разреза «Березовский» из пяти человек. Этот семинар продолжил цикл работ по определению функционалов ключевых должностных лиц предприятия - главных инженеров, заместителей директоров по ОТ и ПК, начальников ОТиЗ, начальников производственных участков, горных мастеров $[1,2,3,4,5,6,7]$.

Необходимость проведения семинара обусловлена неоднозначностью функционала и должности заместителя директора по производству. Как правило, на горнодобывающих предприятиях такой должности не существует и на ряде угледобывающих она тоже отсутствует. В связи с этим была поставлена цель семинара - определение предназначения, ответственности и полномочий заместителя директора по производству, методов достижения целей, критериев для оценки его деятельности.

Участники семинара работали в группах по задачам: «Функционал заместителя директора по производству», «Методы повышения эффективности производства», «Методы повышения безопасности производства», «Методы улучшения использования ФОТ». Группа разреза «Березовский» занималась разработкой норм организации производственного процесса ремонта и замены конвейерной ленты. В этой статье представлено обобщение наиболее важных результатов всех групп. Более подробно результаты работы каждой группы представлены в соответствующих статьях настоящего номера журнала «Уголь».

По мере решения задач участники представляли на обсуждение получаемые результаты, которые оценива- лись на соответствие требованиям собственника и руководства компании. На многочисленных примерах из текущей производственной деятельности, организации деятельности промышленности в период отечественной войны участники могли убедиться в том, что ни один из них не имеет конкретной ответственности за конкретные объекты и показатели деятельности, хотя имеет значительные полномочия.

Участники семинара определили, что и заместитель директора по производству, и главный инженер должны в равной мере отвечать за обеспечение безопасности и эффективности деятельности каждого производственного подразделения: главный инженер - в части повышения технологичности; заместитель директора по производству - в части повышения слаженности (pumмичности) работы (см. рисунок).

Область ответственности главного инженера - разработка технологических решений, обеспечивающих достижение поставленной цели, контроль за ее реализацией. Его инструментами управления являются технологические схемы, паспорта, ПОРы.

Заместитель директора по производству должен отвечать за организацию согласованной, ритмичной работы всех подразделений предприятия с максимальным использованием возможностей технологической системы и минимальным расходом ресурсов. Его инструментами управления являются организационные регламенты, нормы, стандарты, ФОТ.

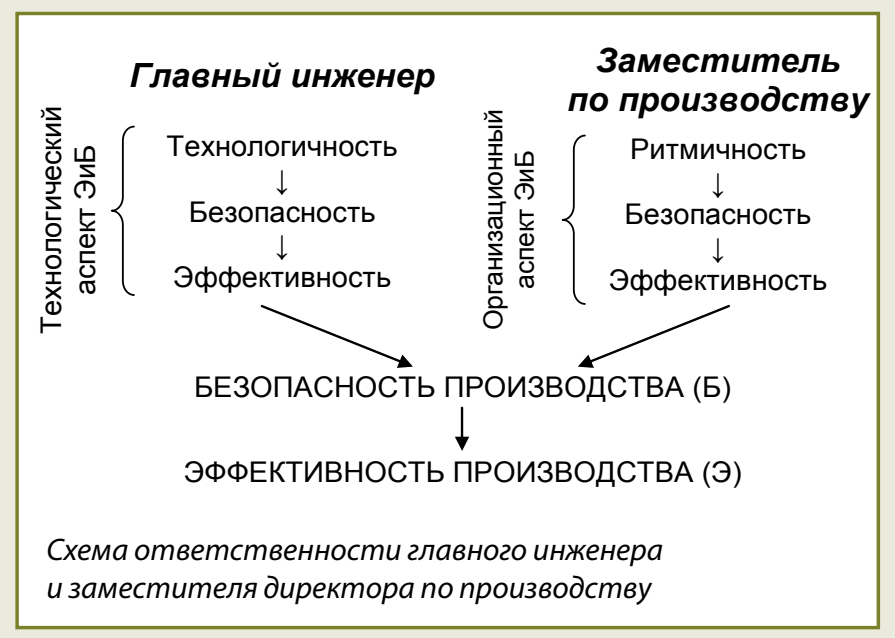




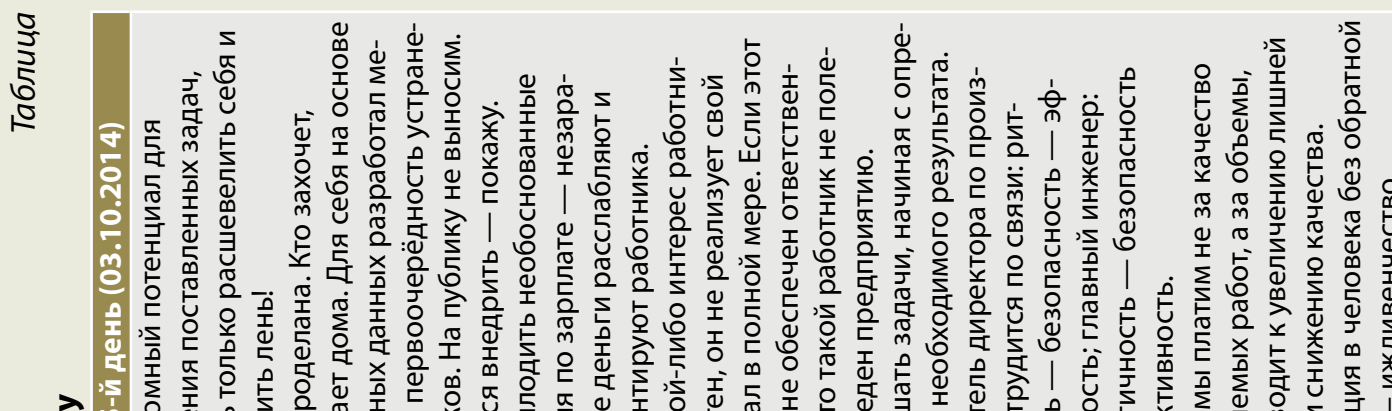

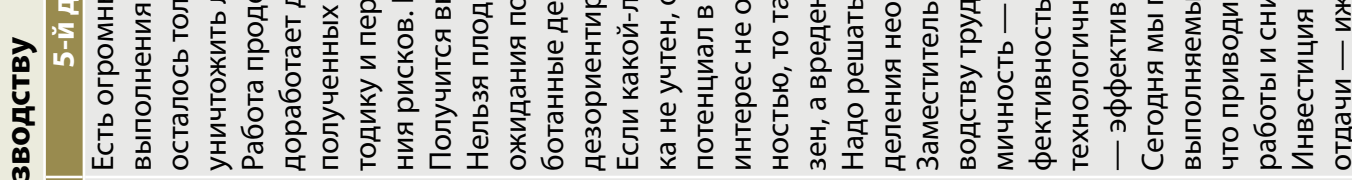

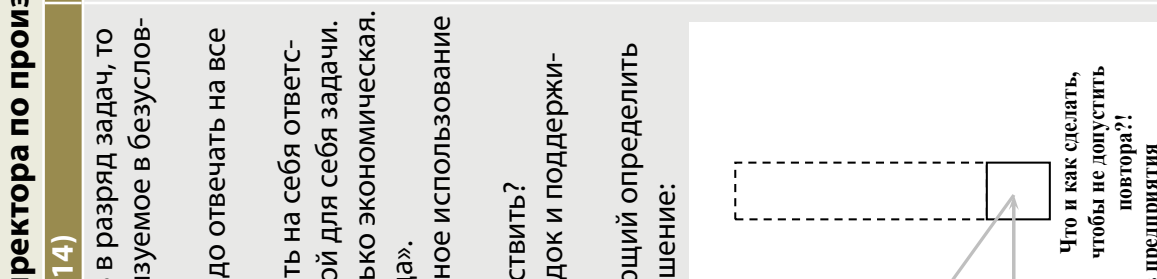
$\begin{array}{lllll} & \\ 0\end{array}$

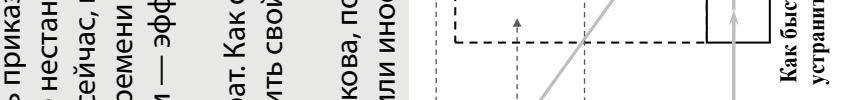

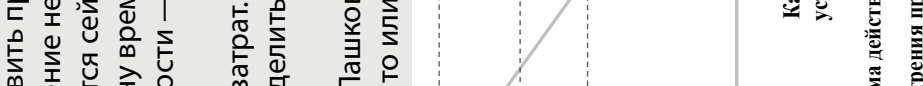

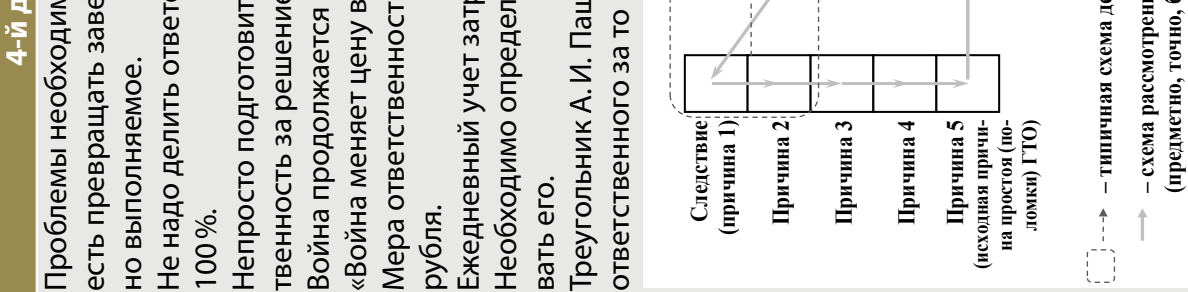

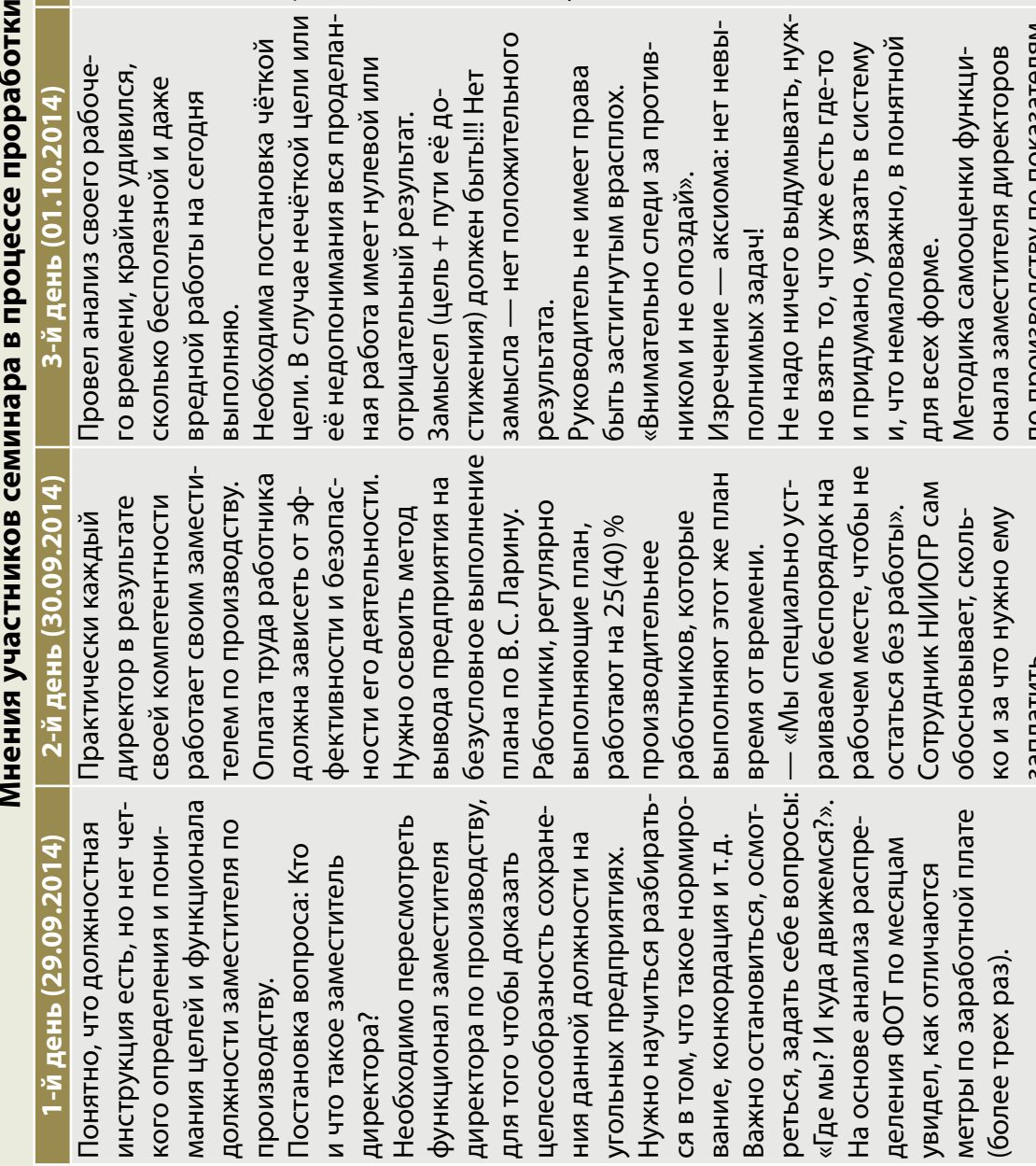


Динамика изменения представлений участников семинара о функционале отражена в таблице.

В результате работы участники пришли к выводу, что для значительного повышения ритмичности, безопасности и эффективности производства необходимо решить следующие задачи:

- определить и утвердить в каждой производственной единице предназначение заместителя директора по производству;

— определить функционал и зону ответственности заместителя директора по производству как управление ритмичностью, безопасностью и эффективностью работы производственной системы;

- разработать показатели оценки результатов деятельности заместителя директора по производству на основе динамики ритмичности, безопасности и эффективности производства;

- сформировать и освоить систему управления рисками негативных событий в производственном процессе на основе контроля за опасными производственными ситуациями;

- разработать нормы организации производственных процессов;

- сформировать систему оплаты труда руководителей и специалистов с учетом ритмичности, безопасности и эффективности производства.

Результаты семинара показали, что слой заместителей директоров предприятий по производству обладает значительным деловым потенциалом, эффективность использования которого может быть существенно повышена посредством четкого определения и полного освоения функционала, направленного на обеспечение требуемого уровня ритмичности, безопасности и эффективности производства.

\section{Список литературы}

1. Евтушенко Е. М., Завьялов М.Ю. Функционал горного мастера угольного разреза // Уголь. 2011. №10. С. 59-62.

2. Добровольский А. И., Феофанов Г.Л., Шивырялкина О.С. Развивающая аттестация управленческого персонала ОАО «Ургалуголь»// Уголь. 2013. №3. С. 104-109.

3. Дьяконов А.В., Артемьев В.Б. Развитие функционала начальника участка для повышения эффективности и безопасности производства на угольном разрезе // Уголь. 2013. №11. С. 64-67.

4. Шивырялкина О.С., Коркина Т. А. Профессионализм руководителя производственного подразделения предприятия как фактор эффективности и безопасности труда (на примере угледобывающей отрасли) // Уголь. 2014. №2. C. 43-47.

5. О функционале главного инженера / Ю. Г. Андреев, А. С. Мануильников, В. В. Машталлер, С.Н. Радионов, С. В. Скотников, И.Л. Харитонов // Уголь. 2014 . №5. C. 74-77.

6. Сальников А.А., Кравчук И.Л., Макаров А. М. О функционале службы охраны труда и производственного контроля // Уголь. 2014. №6. С. 58-60.

7. Костарев А.С., Захаров С.И., Макаров А. М. О развитии функционала отдела организации и оплаты труда //Уголь. 2014. №7. С. 63-66.
Title

\section{FUNCTIONS OF DEPUTY OPERATIONAL DIRECTOR}

\section{Author}

Makarov A.M.

\section{Authors' Information}

Makarov A.M., executive director of "Scientific-research institute of efficiency and safety of mining"Itd., Doctor of engineering science, professor, Chelyabinsk, Russia, e-mail: makarovam_niiogr@mail.ru

\section{Abstract}

The article presents the results of the analytical and simulative seminar on functions of deputy operational director of the company of "SUEK" coal mining complex.

\section{Keywords}

Functionality, Smooth Production Flow, Manufacturability, Effectiveness and Industrial Safety.

\section{References}

1. Yevtushenko E.M., and Zavjalov M.Y. Functions of the open-pit coal mine overman. [Funktsipnal gornogo mastera ugolnogo razreza.] Ugol-Coal, 2011, №10, S.59-62.

2. Dobrovolsky A.I., Feofanov G.L., and Shivyryalkina O.S. Developing certification of managers of "Urgalugol". [Razvivayushchaya attestatsia upravlencheskogo personala OAO "Urgalugol"] Ugol-Coal, 2013, №3, S.104-109.

3. Dyakonov A.V. and Artemyev V.B. Development of overman functions to improve the efficiency and safety at the open-pit coal mine. [Razvitie funktsionala nachalnika uchastka dlia povyshenia effectivnosti i bezopasnosti proizvodstva na ugolnom razreze] Ugol-Coal, 2013, №11, S.64-67.

4. Shivyryalkina O.S., and Korkin T.A. Enterprise production manager professionalism as the factor of effectiveness and safety (the case of the coal mining industry). [Professionalizm rekovoditelia proizvodstvennogo podrazdelenia predpriyatia kak factor effektivnosti I bezopasnosti truda (na primere ugledobyvayushchey otrasli).] Ugol-Coal, 2014, №2, S.43-47.

5. Andreev Y.G., Manuilnikov A.S., Mashtaller V.V. et al. About the functions of the chief engineer. [O funktsionale glavnogo inzhenera] Ugol-Coal, 2014, №5, S.74-77.

6. Sal'nikov A.A., Kravchuk I.L., and Makarov A.M. About the functions development of the labor development and payment department. [O razvitii funktsionala otdela organizatsii I oplaty truda] Ugol-Coal, 2014, № 6, S.58-60.

7. Kostarev A.S., Zakharov S.I., Makarov A.M. About the functions development of the labor organization and payment department. [O razvitii funktsionala otdela organizatsii I oplaty truda] Ugol-Coal, 2014, №7, S.63-66. 


\section{0беспечение повышения безопасности производства как важная часть функционала заместителя директора по производству угледобывающего предприятия}
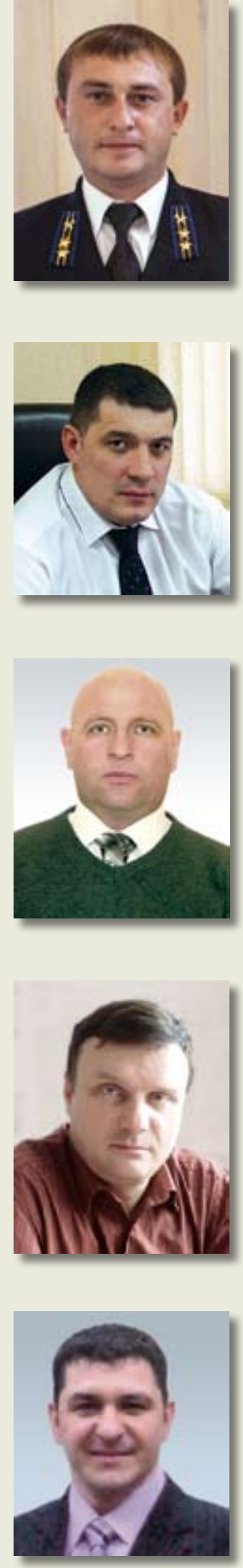

MУРAВЬEВ

Юрий Владимирович

Заместитель

исполнительного директора

по производству

ОАО «Разрез Изыхский»,

с. Белый Яр,

Республика Хакасия, Россия

\section{ФАЛЯХОВ}

\section{Рамазан Юсупович}

Заместитель директора

по производству

шахты «Полысаевская»

OАО «СУЭК-Кузбасс»

2. Ленинск-Кузнецкий, Россия

\section{ПАХОМОВ}

\section{Александр Анатольевич}

Заместитель директора по производству

000 «Читауголь»

cm. Голубичная,

Забайкальский край, Россия

\section{КРАВЧУК}

\section{Игорь Леонидович}

Директор по безопасности горного производства ООО «НИИОГР»,

доктор техн. наук

2. Челябинск, Россия, e-mail:kravchuk65@mail.ru

\section{ГАЛКИН}

\section{Алексей Валерьевич}

Научный сотрудник

ООО «НИИОГР»,

канд. техн. наук

2. Челябинск, Россия,

e-mail:a.val.galkin@yandex.ru
В статье представлены результаты работы одной из групп участников аналитико-моделирующего семинара, которая решала задачу разработки методов повышения уровня безопасности производства как важной составляющей функционала заместителя директора по производству предприятий угледобывающего комплекса ОАО «СУЭК».

Ключевые слова: функционал, организация труда, безопасность производства, методы повышения безопасности производства.

Какие инструменты есть у заместителя директора по производству для повышения безопасности производства и как повысить их действенность? Эти вопросы прорабатывала группа «Методы повышения безопасности производства» в рамках аналитико-моделирующего семинара по определению функционала заместителя директора по производству.

Результаты расследований несчастных случаев показывают, что большинство из них Вызвано организационными причинами, в том числе качеством нарядной системы [1, 2], которая является зоной ответственности заместителя директора по производству. Главный инженер и заместитель директора по производству должны взаимодополнять друг друга при решении задачи обеспечения требуемого уровня безопасности производства: главный инженер отвечает за технологичность работ, а заместитель по производству - за их организованность (рис. 1).

В качестве основного организационного элемента обеспечения безопасности производства группа рассматривала систему производственного контроля. Чтобы целенаправленно, управляемо повышать безопасность, необходимо освоить такой инструмент, как систематическая работа с рисками травмирования. Группой предложен механизм его применения: составление

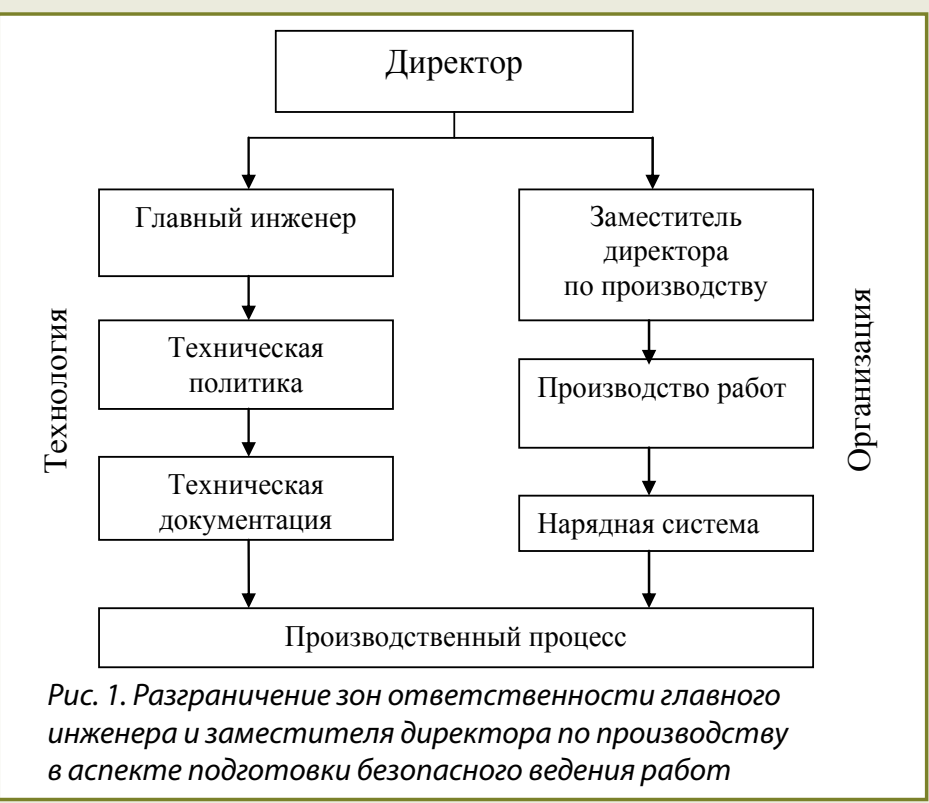


ПРОЕКТ ПРИКАЗА

О снижении риска негативного события (травма, авария, инцидент) в 1,3-1,5 раза в 2015 г.

\section{ПРИКАЗЫВАЮ:}

Вменить заместителю директора по производству ответственность за ритмичность, безопасность и эффективность производственных процессов и наделить его необходимыми для этого полномочиями. В связи с этим заместителю директора по производству:

1. В срок до 01.12.2014 предоставить реестр ОПС, характерных для основных производственных участков.

2. Совместно с отделом ПКиОТ провести аттестацию всех ИТР производственныхучастков на предмет готовности к снижению рисков, Связанных с наличием ОПС. Срок исполнения - 01.12.2014.

3. Организовать с 01.12.2014 ежесменный контроль ОПС на производственных участках лицами старшего надзора и отдела ПКиОТ.
Выполнение наряда на производство работ начинать с устранения нарушений требований безопасности, зафиксированных в «Единой книге предписаний».

4. Организовать планирование месячного производственного задания по участкам сучетом оценки рисков травмирования, обусловленных ОПС.

5. До 20.12.2014 совместно с заместителем директора по персоналу заместителю директора по производству пересмотреть структуру управления предприятием с целью охвата всех процессов и объектов предприятия.

6. Ответственным лицом за повышение безопасности производственных процессов назначить заместителя директора по производству с внесением изменений в должностную инструкцию.

Контроль за исполнением данного приказа оставляю за собой.

Директор ПЕ

Ф.И.О. реестров рисков травмирования, визуализация рисков, план устранения рисков, мотивация персонала к устранению рисков (рис. 2).

Сучетом разработанной системы методов повышения безопасности производства группа подготовила проект приказа, фрагмент которого представлен выше.

\section{PЕЗЮМЕ}

Разработки группы создают основу для формирования и освоения важной части функционала заместителя директора по производству, связанной с обеспечением безопасности производства на угледобывающем предприятии.

\section{Список литературы}

1. Добровольский А.И. Повышение эффективности производственного контроля на угледобывающем предприятии на основе дифференцированного подхода к снижению риска травмирования персонала: Дис.... канд. техн. наук. М., 2012. 143 с.

2. Галкин А.В.Снижение риска травмирования персонала горнодобывающего предприятия путем совершенствования нарядной системы: Дис. ... канд. техн. наук. М. , 2011. 134 с.

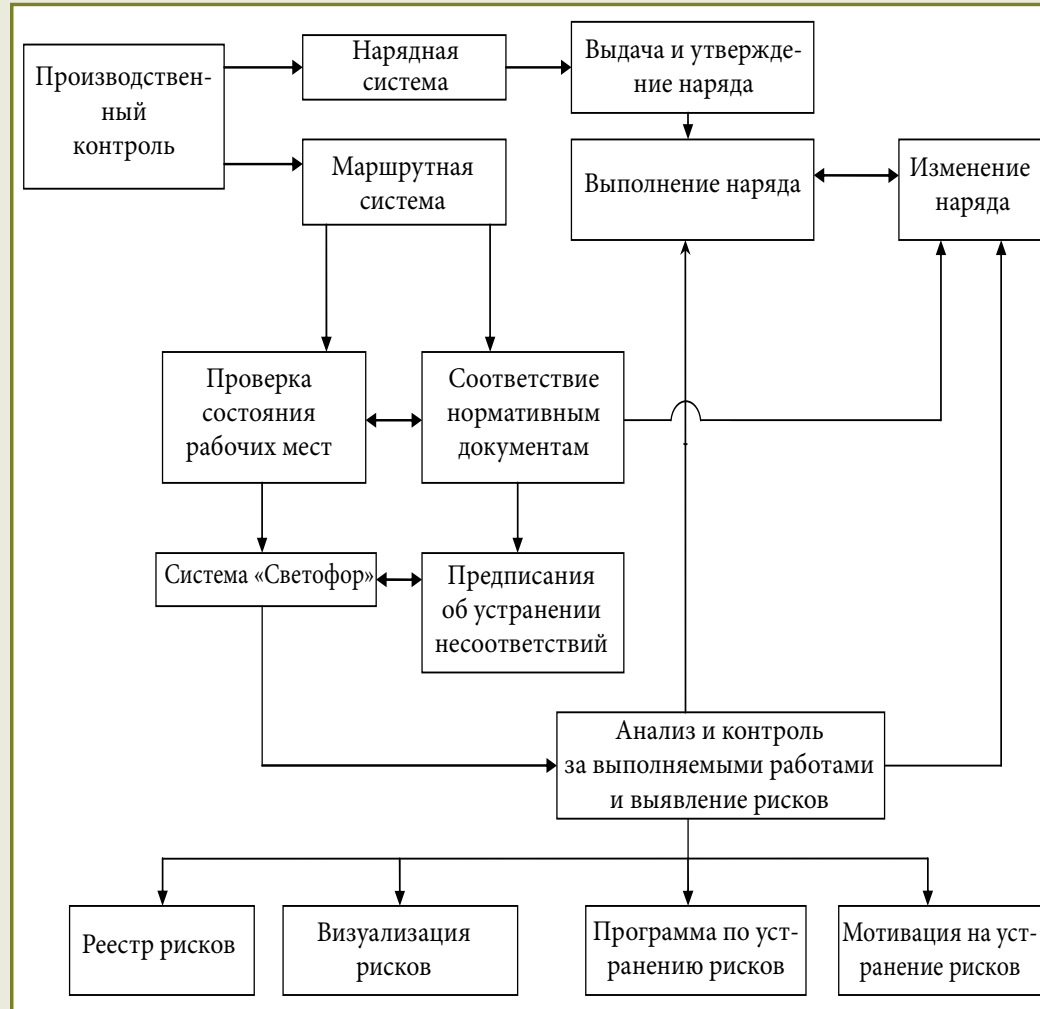

Puс. 2. Система методов повышения безопасности производства

UDC 658.387:658.155:622.33:622.8 @ Y.V. Muravjov, R.Y. Faliahov, A.A. Pahomov, I.L. Kravchuk, A.V. Galkin, 2014 ISSN 0041-5790 • UGOL №11-2014/1064/

\section{Title}

ENHANCED PRODUCTION SECURITY AS AN IMPORTANT PART OF DEPUTY OPERATIONAL DIRECTOR FUNCTIONS AT THE COAL ENTERPRISES

\section{Authors}

Muravjov Y.V., Faliahov R.Y., Pahomov A.A., Kravchuk I.L., Galkin A.V.

\section{Authors' Information}

Muravjov Y.V., deputy executive operational director of "Razrez Izikhskiy" JSC, vil.Beliy Yar, Republic of Khakassia, Russia

Faliahov R.Y., deputy executive operational director of "Polysaevskaya" mine of "SUEK-Kuzbass" JSC, Leninsk-Kuznetski, Russia

Pahomov A.A., deputy operational director of "Chitaugol" JSC, st. Golubichnaya, Zabaykalsky Krai, Russia

Kravchuk I.L., director on mining security of "Scientific-research institute of efficiency and safety of mining" Itd., doctor of engineering science, Chelyabinsk, Russia, e-mail: kravchuk65@mail.ru

Galkin A.V., research scientist of "Scientific-research institute of efficiency and safety of mining" Itd., ph.d. in technical sciences, Chelyabinsk, Russia, e-mail: a.val.galkin@yandex.ru

\section{Abstract}

The article presents the results of participant group work at the analysis and control discussion, which solved the problem of developing methods for improving production safety as an important component of the deputy operational director functions at the "SUEK" coal mining complex.

\section{Keywords}

Functionality, Labor Management, Industrial Safety, Methods of Improving Industrial Safety.

\section{References}

1. Dobrovolsky A.I. Improving the efficiency of production control at coal mines based on the differentiated approach to reduce the risk of personal injury. [Povyshenie effektivnosti proizvodstvennogog kontrolia na ugledobyvayushchem predpriyatii na osnove differentsialnogo podhoda k snigeniyu riska travmirovania personala] ph.d. thesis in tehn. sciences. Moscow, 2012, 143 p.

2. Galkin A.V. Reducing the risk of personal injury at the mining enterprise by improving the smart system. [Snigenie riska travmirovaniya personala gornodobyvayushchego predpriyatia putem sovershenstvovaniya nariadnoy sistemy] ph.d. thesis in tehn. sciences. Moscow, 2011, 134 p. 


\section{Обеспечение повышения эффективности}

\section{производства как важная часть функционала}

\section{заместителя директора по производству}

\section{угледобывающего предприятия}

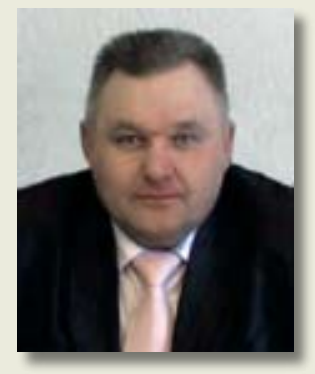

ЛОПАТИН

Сергей Михайлович

Заместитель директора по производству

OAO «Разрез Харанорский»

п. Шерловая Гора,

Забайкальский край, Россия

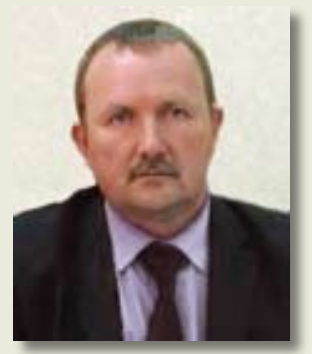

Мухин

Федор Константинович

Заместитель

исполнительного директора

по производству

ООО «Восточно-Бейский

разрез» п. Кирба,

Республика Хакасия, Россия

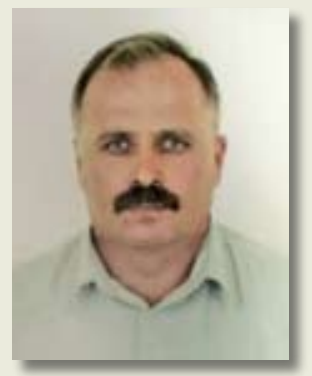

\section{СТЕЦИК}

Василий Алексеевич

Заместитель директора

по производству

Шахтоуправления

«Талдинское-Западное»

ОАО «СУЭК-КузбасС»

2. Ленинск-Кузнечкий, Россия

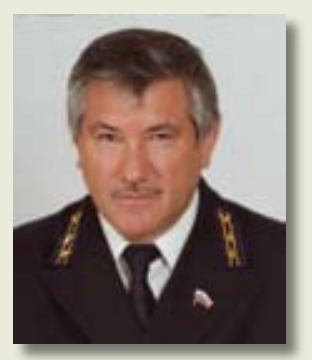

ШЕСТАКОВ

Иннокентий Григорьевич

Заместитель директора

по производству

РУ «Новошахтинское»

ОАО «Приморскуголь»

п. Новошахтинский,

Приморский край, Россия

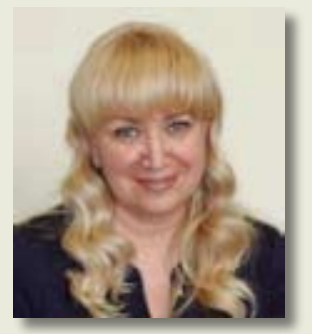

\section{ЛАПАЕВА}

\section{Оксана Анатольевна}

Ученый секретарь

ООО «НИИОГР»,

канд. экон. наук,

2. Челябинск, Россия,

e-mail: lapaeva@yandex.ru
В статье представлены результаты работы одной из групп участников аналитико-моделирующего семинара, которая решала задачу разработки методов повышения уровня эффективности производства как важной составляющей функционала заместителя директора по производству предприятий угледобывающего комплекса ОАО «СУЭК».

Ключевые слова: функционал, организация труда, эффективность производства, методы повышения эффрективности производства.

В рамках аналитико-моделирующего семинара, проведенного в НИИОГР с 29 сентября по 3 октября 2014 г. по определению роли и места заместителя директора по производству в системе управления угледобывающего предприятия, наша группа прорабатывала методы повышения эффективности производства в зоне своей ответственности.

Основные вопросы, активно обсуждаемые в группе, были следующие:

1. Как деятельность заместителя директора по производству влияет на величину затрат на добычу угля?

2. Насколько эффективность производственного процесса поддается контролю?

3. Какова система методов повышения эффективности деятельности у заместителя директора по производству? Какие методы не работают и почему? Что необходимо сделать заместителю директора по производству, чтобы изменить ситуацию?

В ходе проработки этих вопросов наша группа пришла к мнению - в сложившейся на большинстве угледобывающих предприятий системе управления заместитель директора по производству существенно влияет на распределение ресурсов, однако принимаемые им решения ориентированы на объемные показатели деятельности, а не на показатели эффективности и безопасности производства.

Участники группы обратили внимание на то, что инженерные расчеты позволяют с достаточной точностью осуществлять технико-технологическое планирование производства, а точность организационных планов в части обеспечения согласованности взаимодействия на смене между рабочими, экипажами (бригадами), между исполнителями и руководителями не достигает и половины от необходимого. Это проявляется в частых изменениях наряд-задания во время смены, как линейными руководителями, так и заместителем по производству, главным инженером. Измененное наряд-задание организуется и обеспечивается ресурсами «на ходу», «как получится», «из того, что есть в наличии», «как смогли договориться». Такая организация производственных процессов неизбежно приводит к значительному нарушению ритмичности производства и, как следствие, к росту риска травмирования персонала и перерасходу ресурсов [1, 2, 3].

Необходимость разобраться с ответственностью как частью функционала заместителя директора по производству заставила проработать это понятие. Ответственность - это готовность 

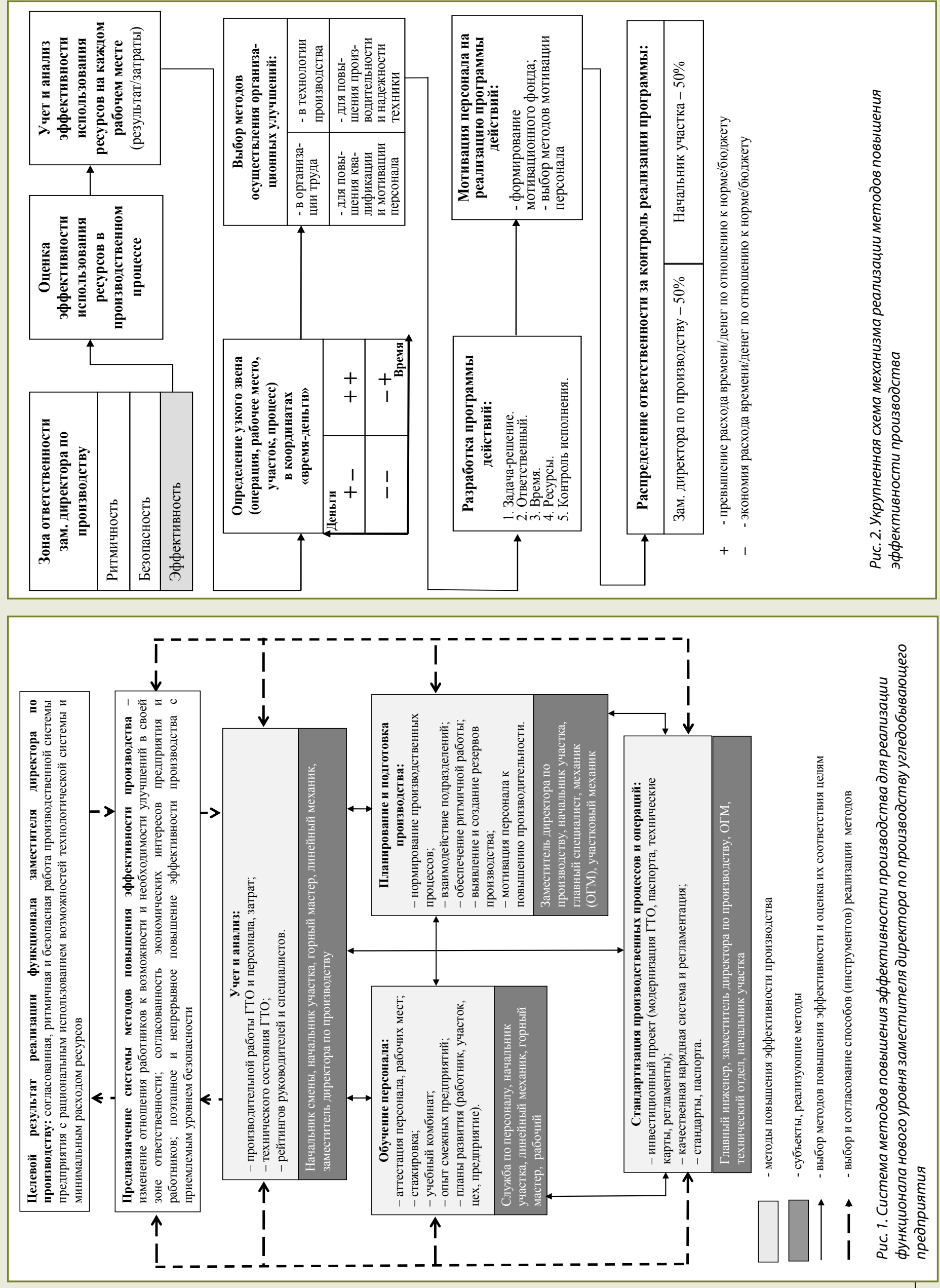
взять на себя груз принятия решения и санкций за неудачу и реализация этой готовности $[4,5,6]$. При таком понимании ответственности для реализации своего функционала с пользой для себя, предприятия, компании заместителю директора по производству нужен эффективный инструментарий (методики, методы, механизм), позволяющий обеспечить требуемый уровень организованности производственного процесса, эффективности и безопасности производства.

Анализируя результативность используемых на предприятиях методов повышения производительности труда, снижения затрат, а также причины того, что эти методы не обеспечивают требуемой динамики развития производства, пришли к пониманию того, что применение на предприятияхэтих методов носит не системный, а преимущественно локальный характер.

Группа предложила систему методов, обеспечивающую согласованность экономических интересов предприятия и работников; поэтапное и непрерывное повышение эффективности производства с приемлемым уровнем безопасности (рис. 1).

Базовым инструментом механизма реализации системы методов является учет и анализ эффективности использования ресурсов [7]. Налаживание оперативного (в режиме реального времени) первичного учета затрат в подразделениях и на предприятии в целом - важный элемент и одновременно условие эффективной работы этого механизма (рис. 2).

Таким образом, наша группа сформировала и предложила для проработки систему методов повышения эффективности производства и механизм ее реализации, позволяющие повысить результаты деятельности заместителя директора по производству и, как следствие, ценность этой должности в системе управления угледобывающего предприятия.

\section{Список литературы}

1. Азев В.А., Артемьев В.Б. Адресно ориентированное совершенствование систем планирования и организации производства на угольных разрезах // Уголь. 2012. №2. С. 50-52.

2. Баскаков, В.П. Стандартизация производственных процессов на угольных шахтах: безопасность, эффективность, стабильность: Доклад на совещании Администрации Кемеровской области с руководителями угледобывающих предприятий и углепрофсоюза по проблеме промышленной безопасности; Кемерово, 15 июня 2007. Кемерово, 2007. 27 с.

3. Кукаренко А.И., Ломовцев В.В., Дьяконов А. В. Основные результаты повышения эффективности производственных процессов в разрезоуправлении «Новошахтинское» ОАО «Приморскуголь» за 2010 год //Уголь. 2011. № 4. С. 58-60.

4. Толковый словарь русского языка: В 4 т. / Г.О. Винокур, Б.А. Ларин, С.И. Ожегов и др. М.: Государственный институт «Советская энциклопедия»; ОГИЗ (Т. 1); Государственное издательство иностранных и национальных словарей (т. 2-4), 1935-1940.

5. Ожегов С. И., Шведова Н.Ю. Толковый словарь русского языка: 80000 слов и фразеологических выражений. Рос. Академ. наук. Ин-т русского языка им. В.В. Виноградова. 4-е изд., доп. М.: Азбуковник, 1999. 944 с.

6. Тейлор Ш., Пипло Л., Сире Д. Социальная психология. СПб.: Питер, 2004. 766 с.

7.Управление развитием горнодобывающего предприятия. Информационные модели и методы /С. Е. Гавришев, А. Н. Рахмангулов, М. В. Грязнов, О. А. Лапаева. Магнитогорск: МГТУ им. Г. И. Носова, 2002. 245 с.

Title IMPROVING PRODUCTION EFFICIENCY AS AN IMPORTANT PART OF THE DEPUTY OPERATIONAL DIRECTOR FUNCTIONS AT THE COAL ENTERPRISES

\section{Authors}

Lopatin S.M., Muhin F.K., Stetsik V.A., Shestakov I.G., Lapaeva O.A.

\section{Authors' Information}

Lopatin S.M., deputy operational director of "Razrez Haranorskiy" JSC, vil. Sherlovaya Gora, Zabaykalsky Krai, Russia.

Muhin F.K., deputy executive operational director of "Vostochno-Beyskiy razrez" Itd., vil.Kirba, Republic of Khakassia, Russia

Stetsik V.A., deputy operational director of mine administration of "TaldinkoeZapadnoe" JSC "SUEK-Kuzbass", Leninsk-Kuznetski, Russia

Shestakov I.G., deputy Production Director of "Novoshakhtinskoe" SMO (surface mine office) of "Primorskugol" JSC, Novoshakhtinskiy, Primorski Krai, Russia

Lapaeva O.A., academic secretary of "Scientific-research institute of efficiency and safety of mining" Itd., ph.d in economics, Chelyabinsk, Russia, e-mail: lapaeva@yandex.ru

\section{Abstract}

The article presents the results of participant group work at the analysis and control discussion, which solved the problem of developing methods for improving production efficiency as an important component of the deputy operational director functions at the "SUEK" coal mining complex.

\section{Keywords}

Functionality, Labor Management, Industrial Efficiency, Methods of Improving Industrial Safety.

\section{References}

1. Azev V.A., and Artemyev V.B. Address-oriented improvement of planning and production organization systems at coal mines. [Adresno-orientirovannoe sovershenstvovanie system planirovaniya I organizatsii proizvodstva na ugolnykh razrezah] Ugol-Coal, 2012, №2, S.50-52.
2. Baskakov V.P. Standardization of production processes at the coal mines: safety, efficiency, stability. Report of the Kemerovo region Administration meeting with the directors of coal mines and coal mine labor union on the issues of industrial safety, [Standartizatsia proizvodstvennykh processov na ugolnykh shahtah: bezopasnost, effektivnost, stabilnost. Doklad na soveshchanii Administratsii Kemerovskoy oblasti s rukovoditeliami ugledobyvayushchih predpriyatiy ugleprofsoyuza po probleme promyshlennoy bezopasnosti, Kemerovo] Kemerovo, June 15, 2007. Kemerovo, 2007, 27 p.

3. Vinokur G.O., Larin B.A., Ozhegov S.I., et al. Explanatory dictionary of Russian language in 4 volumes. [Tolkovyi slovar russkogo yazyka v 4-h tomah] Moscow State Institute "Soviet Encyclopedia", OGIZ(Volume 1), Gosudarstvennoe izdatelstvo inostrannykh I natsianInyh slovarey - State Publishing House of Foreign and National Dictionaries (Volume 2-4), 1935-1940.

4. Kukarenko A.I., Lomovtsev V.V., and Deakonov A.V. Main results of improving the production processes efficiency at the "Novoshakhtinskoye" surface mine office of "Primorskugol" in 2010. [Osnovnye rezultaty povyshenia effektivnosti proizvodstvennykh processov v razrezoupravlenii "Novoshakhtinskoe" OAO "Primorskugol" za 2010 god.] Ugol-Coal, 2011, № 4, S.58-60.

5. Gavrishev S.E., Rakhmangulov A.N., Grjaznov M.V. and Lapaeva O.A. Managing the development of the mining enterprise. Information models and methods. [Upravlinie razvitiem gornodobyvayushchego predpriyatia. Informatsionnye modeli I metody.] Magnitogorsk, MGTU im. I.G. Nosova - MSTU G.I. Nosov memorial, 2002, $245 \mathrm{p}$.

6. Ozhegov S.I., and Shvedova N.Y. Explanatory Dictionary of Russian language, 80,000 words and idiomatic expressions. [Tolkovyy slovar russkogo yazyka, 80000 slov I frazeologicheskih vyrazheniy] Ros. Sciences Acad., Institute of Russian Language. Vinogradova V.V., 4th ed., Ext. Moscow, Azbukovnik, 1999, 944 p. 7. Taylor S., Peeplo L., and Syro D. Social Psychology. [Sotsialnaya psihologia] St. Petersburg, Peter, 2004, 766 p. 


\section{Об использовании}

\section{фонда оплаты труда предприятия}

В статье представлены результаты работы одной из групп участников аналитико-моделирующего семинара, которая решала задачу повышения эффективности использования фонда оплаты труда как важной составляющей функционала заместителя директора по производству предприятий угледобывающего комплекса ОАО «СУЭК».

Ключевые слова: функционал, структура времени работы, фонд оплаты труда.

В рамках семинара, проведенного в НИИОГР с заместителями директоров по производству по определению их функционалов, решалась задача улучшения использования фонда оплаты труда (ФОТ). ФОТ - один из важнейших ресурсов руководителей разного уровня [1], в том числе заместителя директора по производству.

ФОТ используется эффективно, если снижаются удельные затраты на оплату труда на единицу продукции при увеличении размера оплаты труда работников [1, 2, 3].

Работа группы началась с поиска ответа на вопрос: «Насколько эффективно на сегодняшний день используется ФОТ?». Для этого было решено посмотреть, как меняется показатель удельных затрат ФОТ на приведенный один погонный метр горных выработок (ФОТп.м.) одной из проходческих бригад (рис. 1).

$$
\text { ФOTп.м. }=\frac{\text { ФОТмес. }}{Q_{\text {мес. }}{ }^{*} \mathrm{Km}},
$$

где ФОТмес. - месячный фонд оплаты труда; Qмес. - количество пройденных погонных метров горных выработок за месяц; $\mathrm{Km}$ - коэффициент тяжести (сложности) пройденных погонных метров горных выработок. Значение коэффициента тяжести по каждому месяцу было определено экспертно, исходя из сложности горно-геологических условий.

Из графика видно, что в разные месяцы удельные затраты ФОТ на приведенный погонный метр различаются в три раза.

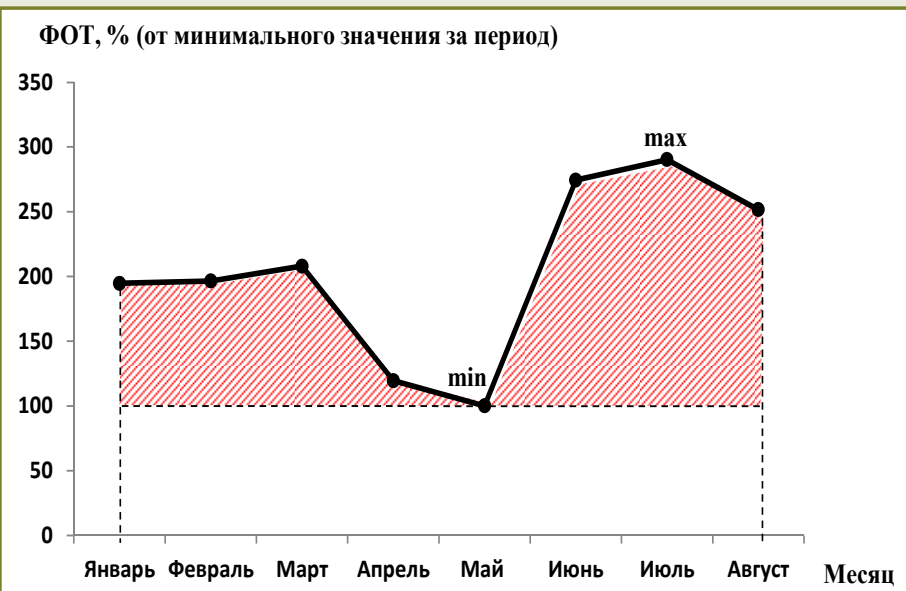

Рис. 1. Динамика удельных затрат ФОТ на 1 п. м. горных выработок на примере одной из проходческих бригад Шахтопроходческого управления ОАО «СУЭК-Кузбасс»

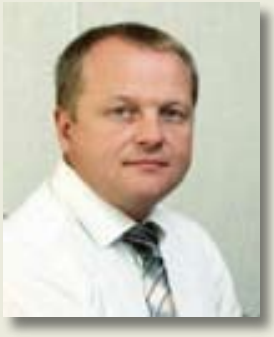

\section{БРОСТ}

Владислав Эдуардович

Директор по производству

Разрезоуправления

ОАО «СУЭК-Кузбасс»

г. Ленинск-Кузнецкий, Россия

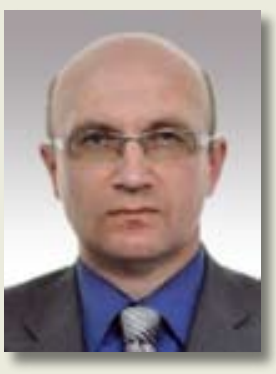

\section{МАШТАЛЛЕР}

\section{Владимир Викторович}

Заместитель

управляющего филиалом

по прочзводству - начальник

производственного управления

филиала ОАО «СУЭК-Красноярск»

«Разрез Бородинский

им. М.И. Щадова»

г. Бородино, Россия

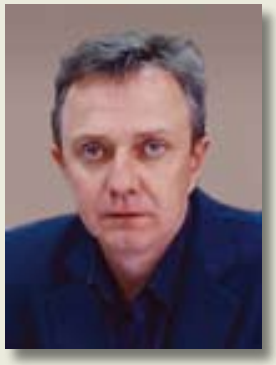

\section{РУДЕНКО}

\section{Александр Трофимович}

Заместитель исполнительного

директора по производству

ОАО «Ургалуголь»

n. Чегдомын,

Хабаровский край, Россия

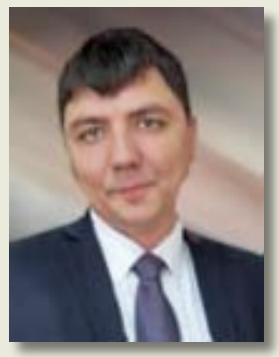

\section{ТАЦИЕНКО}

Александр Леонидович

Заместитель директора

по производству

Шахтопроходческого управления

ОАО «СУЭК-Кузбасс»

2. Ленинск-Кузнецкий, Россия

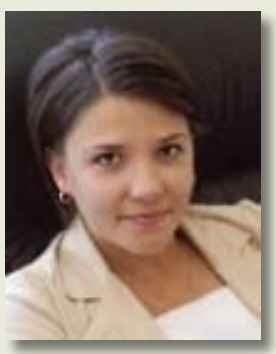
ШИВЫРЯЛКИНА
Ольга Сергеевна
Научный сотрудник
ООО «НИИОГР»,
канд. экон. наук,
2. Челябинск, Россия
e-mail:olga_niiogr@bk.ru 
Найти удовлетворительных объяснений этому не удалось. Возник следующий вопрос: почему происходят такие «nерекосы» в распределении ФОТ?После обсуждения участники группы пришли квыводу, что такая ситуация является следствием некачественного управления ФОТом. Для решения этой проблемы была разработана блок-схема, применение которой позволит, на наш взгляд, усилить связь результатов труда работника с его оплатой (рис. 2).

Применение данной блок-схемы позволит выстроить такую систему взаимоотношений работников предприятия (от рабочего до исполнительного директора), в которой каждый будет заинтересован в повышении своей ценности для предприятия, что обеспечит рост уровня доходов, не выходя за рамки имеющегося фонда оплаты труда.

Сцелью определения ценности заместителя директора по производству для предприятия участниками группы была проведена самооценка структуры рабочего времени по критериям полезности выполняемой работы («полезная - бесполезная - вредная») и перспективности решаемых задач («вчера - сегодня - завтра - послезавтра») (рис. 3).

На основе собственных оценок заместители директоров по производству определили, что на полезную работу при-

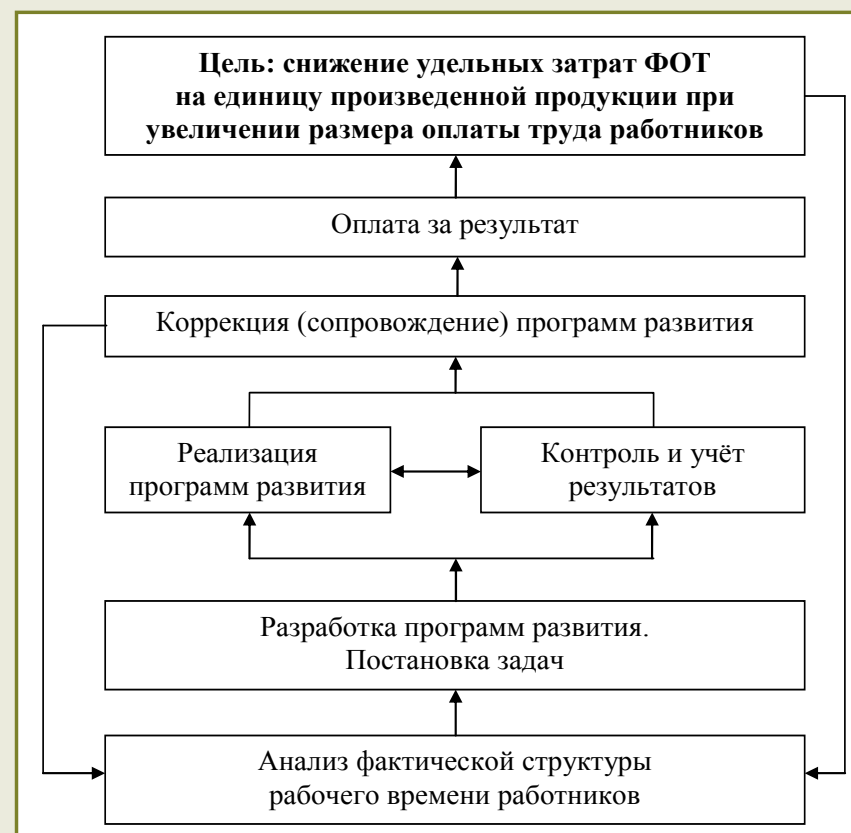

Рис. 2. Блок-схема повышения эффрективности управления ФОТом

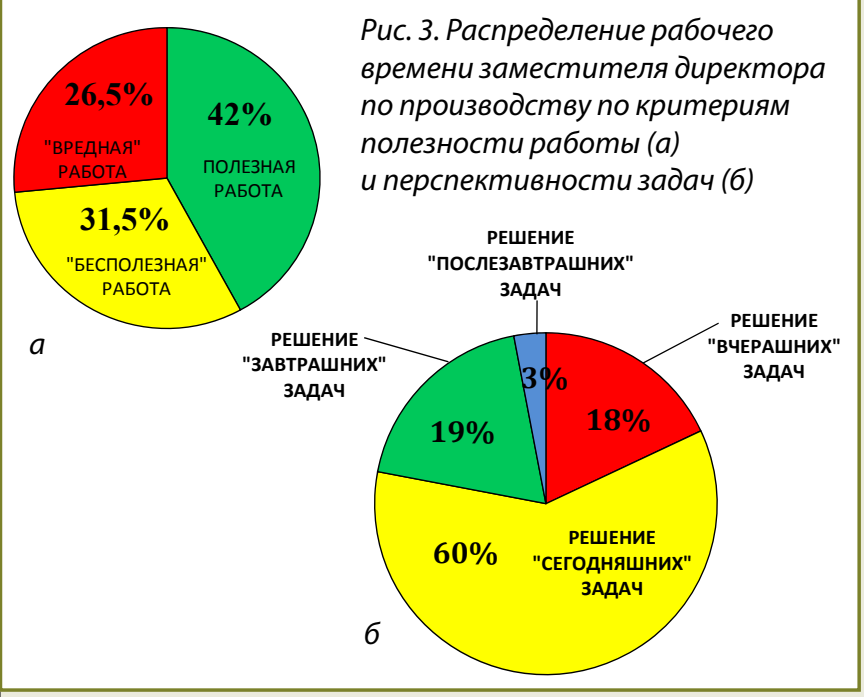

ходится около 42 \% рабочего времени, на «бесполезную» и «вредную» относительно решения задач развития $31,5 \%$ и 26,5\%, соответственно. Основную часть «вредной» работы составляет корректировка текущих наряд-заданий, поскольку это нарушает заранее спланированный порядок выполнения работ.

Анализ и оценка рабочего времени заместителя директора по производству позволили увидеть, что для повышения его ценности необходимо повысить долю времени на решение перспективных задач, одной из которых является улучшение использования ФОТа.

\section{Список литературы}

1. Костарев А.С., Макаров А. М., Захаров С.И. О развитии функционала отдела организации и оплаты труда //Уголь. 2014. №7. С. 57-60.

2. Модели повышения эффективности и безопасности производства посредством совершенствования организации и оплаты труда / В.С. Алексенко, Ф.И. Акшенцев, О.Б. Браун и др. Отдельная статья ГИАБ (Сер. «Б-ка горного инженера-руководителя». Вып. 18.). М.: Горная книга, 2012. №4. 52 c.

3. Организационная подготовка безопасной и высокопроизводительной работы персонала на предприятияхОАО «Ургалуголь»: отчет за I этап / НИИОГР. Чегдомын - Челябинск: НИИОГР, 2012. 120 с.

UDC [658.387+658.32]:658.155:622.33 ๑ V.E. Brost,

V.V. Mashtaller, A.T. Rudenko, A.L. Tatsienko,

O.S. Shivyrialkina, 2014 ISSN 0041-5790 • UGOL №11-2014/1064/

Title

\section{ABOUT THE USE OF THE COMPANY SALARY BUDGET}

\section{Authors}

Brost V.E., Mashtaller V.V., Rudenko A.T., Tatsienko A.L., Shivyrialkina O.S.

\section{Authors' Information}

Brost V.E., operational director of surface mine office of "SUEK-Kuzbass" JSC, Leninsk-Kuznetski, Russia

Mashtaller V.V., deputy manager of manufacturing branch, chief of the production office of "SUEK-Krasnoyarsk" branch of "Razrez Borodinskiy M.I. Shchadova memorial" JSC, Borodino, Russia.

Rudenko A.T., deputy executive operational director of "Urgalugol" JSC, vil. Chegdomin, Khabarovsk Krai, Russia

Tatsienko A.L., deputy executive operational director of sinking administration of "SUEK-Kuzbass" JSC, Leninsk-Kuznetski, Russia

Shivyrialkina 0.S., research scientist of "Scientific-research institute of efficiency and safety of mining"Itd., ph.d in economics, e-mail: olga_niiogr@bk.ru

\section{Abstract}

The article presents the results of participant group work at the analysis and control discussion, which solved the problem of developing methods for improving efficiency of salary budget use as an important component of the deputy operational director functions at the "SUEK" coal mining complex.

\section{Keywords}

Functionality, Work Time Structure, Salary Budget.

\section{References}

1. Kostarev A.S., Makarov A.M., and Zakharov S.I. About the functions development of the organization and payment department. [O razvitii funktsionala otdela organizatsii I oplaty truda] Ugol-Coal, 2014, №7, S.57-60. 2. Aleksenko V.S., Akshentsev F.I., Brown O.B. et al. Models for improvement the efficiency and safety through better organization and remuneration. [Modeli povyshenia effektivnosti I bezopasnosti proizvodstva posredstvom sovershenstvovania organizatsii I oplaty truda] GIAB-MIAB 2012, №4. 52. 3. Organizing the safe and high-performance work at "Urgalugol"Itd. Report for Phase I, SRIESM. [Organizatsionnaya podgotovka bezopasnoy I vysokoproizvoditelnoy raboty personala na predpriyatiyah OAO "Uralugol", otchet za I etap, NIIOGR] Chegdomyn - Chelyabinsk, NIIOGR - SRIESM 2012, 120 p. 


\section{О структуре функционала зам
директора по производству}

\begin{abstract}
В статье представлены результаты работы одной из групп участников аналитико-моделирующего семинара, которая решала задачу по определению и уяснению роли и структуры функционала заместителя директора предприятия по производству, освоение которого обеспечит достижение требуемого уровня ритмичности функционирования производственной системы и на этой основе эффективности, безопасности производства предприятий угледобывающего комплекса ОАО «СУЭК».

Ключевые слова: функционал, заместитель директора по производству, ритмичность, безопасность, эфффективHOCmb.
\end{abstract}

В условиях усиления конкуренции в отрасли и неуклонного возрастания требований к безопасности и эффективности производства требуются определение и уяснение роли и структуры функционала заместителя директора по производству угледобывающего предприятия.

Для решения этой задачи группа использовала модели управления, предложенные в работе А.Н. Сывороткина (табл. 1) [1].

Суть моделей заключается в том, что руководитель, у которого взаимоувязаны все функции управления, обязательно получает в качестве результата своей деятельности ритмичное, безопасное и эффективное производство, а руководитель, у которого слабо взаимоувязаны функции управления, получает обратные результаты - неритмичное, небезопасное и неэффективное производство.

В ходе обсуждения и проработки этих моделей были сформулированы следующие положения:

- заместитель директора по производству - первый заместитель директора, руководитель, организующий достижение целей и выполнение всеми структурными подразделениями предприятия и сторонними организациями поставленных задач с приемлемым уровнем безопасности и эффективности производства;

- функционал заместителя директора по производству заключается в обеспечении ритмичности, безопасности и эффективности функционирования производственной системы предприятия.

Группой была предложена пятибалльная шкала для оценки результатов деятельности заместителя директора по производству (табл. 2).

Разработанная шкала была использована для самооценки результатов деятельности одного из участников группы. Ее применение позволило установить, что «узким звеном», а следовательно, и перспективной «точкой роста» результатов деятельности заместителя директора по производству является эффективность использования ресурсов (рис. 1).

Поскольку эффективность использования ресурсов - это соотношение результатов и затрат, то важным шагом к улуч-

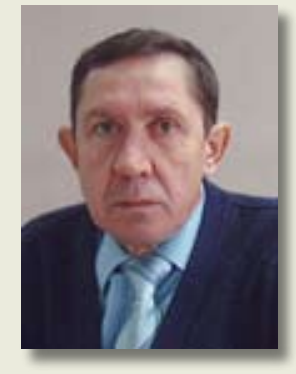

\section{ГOPEB}

Евгений Владимирович

Заместитель директора по производству разреза «Черногорский» ООО «СУЭК-Хакасия»

2. Черногорск, Россия

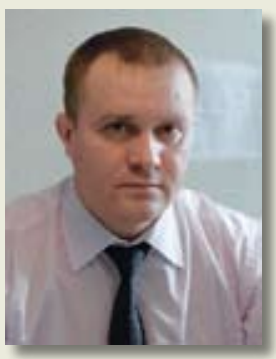

\section{ПЕРОВ}

Евгений Викторович

Заместитель директора

по производству

шахты им. 7 Ноября

ОАО «СУЭК-КузбасС»

2. Ленинск-Кузнецкий, Россия

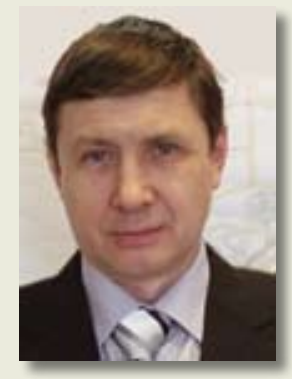

\section{РЫБИНСКИЙ \\ Андрей Борисович}

Заместитель исполнительного

директора по производству

ОАО «Разрез Тугнуйский»

n. Саган-Нур,

Республика Бурятия, Россия

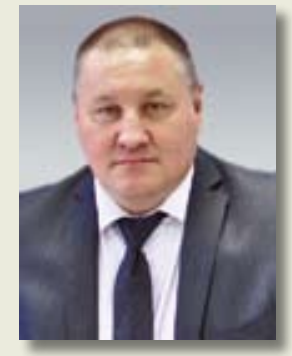

\section{Сигитов}

\section{Игорь Витальевич}

Заместитель директора

по производству

шахтоуправления «Котинское»

ОАО «СУЭК-Кузбасс»

г. Ленинск-Кузнецкий, Россия

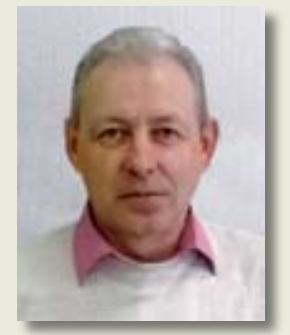

\section{ДОВЖЕНОК}

\section{Александр Сергеевич}

Ведущий научный сотрудник

ООО «НИИОГР»,

доктор техн. наук

2. Челябинск, Россия,

e-mail:dovgenok@bk.ru 
Модели и результаты управления

\section{Описание модели управления}

Высокоэффективная - основные функции управления взаимоувязаны между собой

Низкоэффективная - основные функции управления слабо связаны между собой

\section{Схема модели управления}
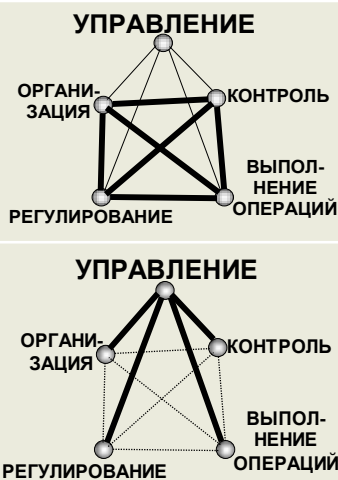

Результаты управления
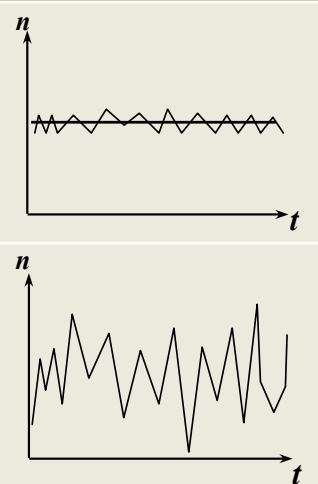

- - сильная связь; ---_- - слабая связь;

$n$ - важные показатели управляемого процесса: производительность, безопасность, эффективность; $t$ - время

Таблица 2 шению деятельности заместителя директора

\section{Шкала для оценки результатов деятельности заместителя директора по производству}

Параметр производс-
твенного процесса
Безопасность

Эффективность

P

\section{Риски травмирования персонала:}

\section{Результаты}

Оценка,

балл

- на уровне мировых лидеров

- на уровне российских лидеров

- на уровне лидера компании

- на уровне середняка компании

- на уровне аутсайдера компании

Использование месячного лимита затрат:

- экономия $30 \%$ и более

- экономия $15-30 \%$

- отсутствие экономии и перерасхода

— перерасход до $15 \%$

- перерасход более $15 \%$

\section{5}

4

3

2

1

Отклонение от средних значений месячного, суточного, сменного, часового плана:

- не более 10\%
- $10-35 \%$
- $35-55 \%$
- 55-80\%
- более $80 \%$
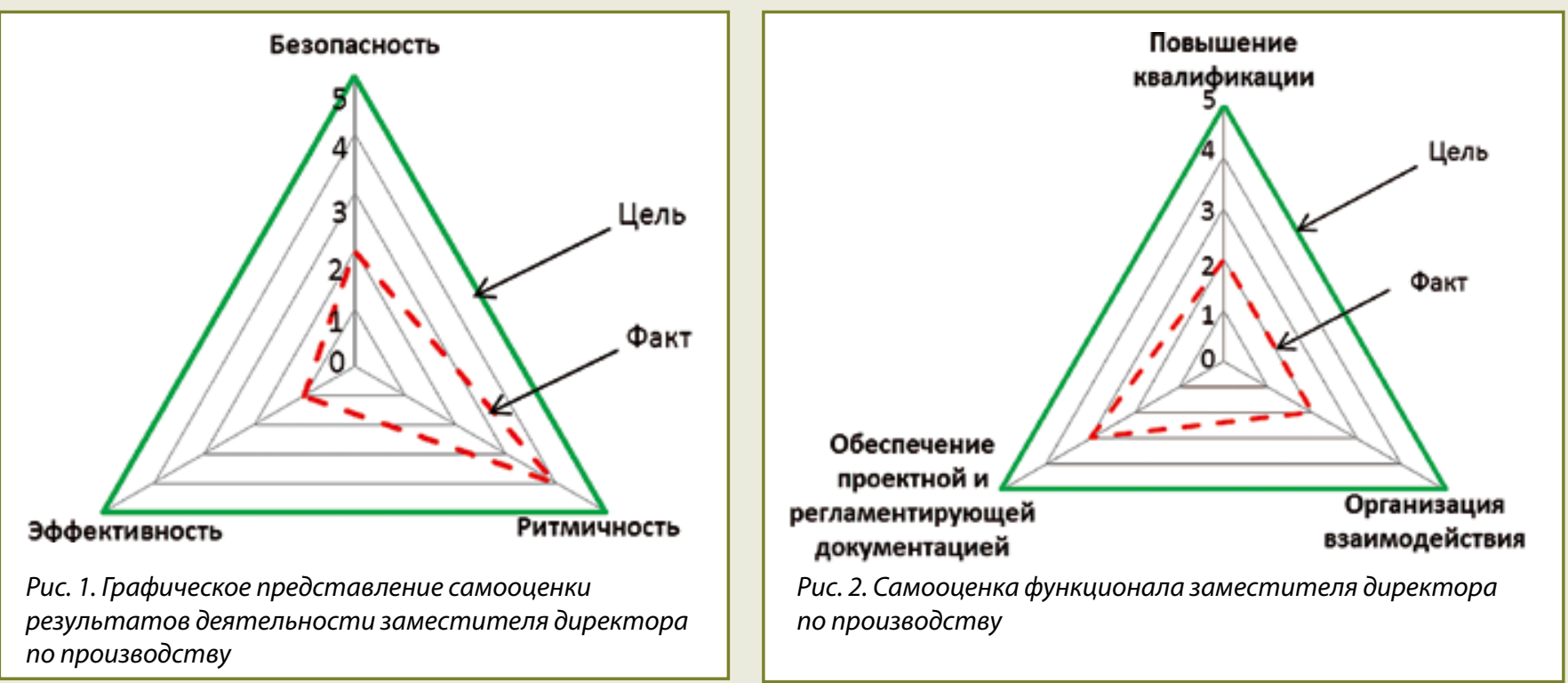
по производству является организация ежесуточного учета затрат по предприятию [2].

Достижение целевых результатов деятельности обеспечивается на основе реализации элементов функционала. Анализ опыта мотивирующей аттестации руководящего персонала на ряде угледобывающих предприятий [3] позволил определить структуру функционала заместителя директора по производству, которая включает повышение квалификации персонала, обеспечение проектной и регламентирующей документацией, организацию взаимодействия персонала, а также разработать шкалу для оценки его состояния (табл. 3).

Самооценка одним из участников группы, произведенная по разработанной шкале, позволила выявить, что наиболее актуальным направлением развития функционала заместителя директора по производству является повышение слаженности взаимодействия и квалификации персонала (рис. 2).

Применение полученных группой результатов в деятельности заместителя директора 
Шкала для оценки функционала заместителя директора по производству

Элементы
функционала
Повышение

квалификации персонала

Обеспечение проектной и регламентирующей документацией

Организация взаимодействия персонала

\section{Состояние}

Квалификация персонала позволяет вести бесперебойный, ритмичный производственный процесс Операционный персонал готов освоить стандарты безопасности и эффективности производства Операционный персонал выполняет работу в соответствии с нормами и нормативами Ведется обучение персонала безопасным и эффективным навыкам работы Операционный персонал выполняет работу небезопасными и неэффективными приемами Проектная документация соответствует высокому уровню безопасности и эффективности производства. Освоены все необходимые для работы инструкции, паспорта, регламенты

Проектная документация позволяет действовать на требуемом уровне безопасности и эффективности производства

Проектная документация позволяет выйти на приемлемый уровень безопасности и эффективности производства

Проектная документация частично используется в силу избыточной формализации

Проектная документация не позволяет предприятию достичь приемлемого уровня безопасности и эффективности производства, т.е. все инструкции и положения формальны

Понимание и стремление всех руководителей структурных подразделений предприятия к цели и конечному результату с определенностью зон ответственности на $100 \%$

Понимание и стремление всех руководителей структурных подразделений предприятия к цели и конечному результату с определенностью зон ответственности на $80 \%$

Понимание и стремление всех руководителей структурных подразделений предприятия к цели и конечному результату с определенностью зон ответственности на $50 \%$

Понимание и стремление всех руководителей структурных подразделений предприятия к цели и конечному результату с определенностью зон ответственности на $30 \%$

Понимание и стремление всех руководителей структурных подразделений предприятия к цели и конечному результату с определенностью зон ответственности менее чем на $30 \%$
Оценка, балл

5 4 3 2 по производству позволяет определить его соответствие требованиям руководства и собственника, и обоснованно разрабатывать наиболее эффективные направления развития функционала.

\section{Список литературы}

1. Сывороткин А.Н. Повышение эффективности использования ресурсного потенциала высокопроизводительных угольных шахт на основе стандартизации производственных процессов: Дис.... канд. техн. наук. М., 2004. 120 c.

2. Килин А.Б. Оргструктура угледобывающего предприятия как декомпозированный функционал его руководителя // Организационное развитие горного предприятия: Отдельный выпуск ГИАБ. 2014. №2 (ОВ). С. 18-29.

3. Добровольский А.И., Феофанов Г.Л., Шивырялкина О.С. Развивающая аттестация управленческого персонала ОАО «Ургалуголь» // Уголь. 2013. № 3. С. 104-109.

Title

ABOUT THE FUNCTIONAL STRUCTURE OF THE DEPUTY OPERATIONAL DIRECTOR

\section{Authors}

Gorev E.V., Perov E.V., Rybinskiy A.B., Sigitov I.V., Dovgenok A.S.

\section{Authors' Information}

Gorev E.V., deputy operational director of "Chernogorskiy" excavating plant of "SUEK-Khakasia"Itd, Chornogorsk, Russia

Perov E.V., deputy operational director of The 7th of November memorial mine of "SUEK-Kuzbass" JSC, Leninsk-Kuznetsky, Russia

Rybinskiy A.B., deputy executive operational director of "Razres Tunguyskiy" JSC, vil. Sagan-Nur, Republic of Buryatia, Russia

Sigitov I.V., deputy executive operational director of mine administration of "Kotinskoe" Itd. of "SUEK-Kuzbass", Leninsk-Kuznetsky, Russia

Dovgenok A.S., leading research scientist of "Scientific-research institute of efficiency and safety of mining" Itd., Doctor of Engineering Science, Chelyabinsk, Russia, e-mail: dovgenok@bk.ru

\section{Abstract}

The article presents the results of participant group work at the analysis and control discussion, which solved the problem of role and structure definition for the functions of deputy operational director. The development of functions will ensure the achievement of the required level of smooth operation of the production system, and as a result, the efficient and safety production of "SUEK" coal mining complex.

\section{Keywords}

Functional, Deputy Production Director, Rhythm, Safety, Efficiency.

\section{References}

1. Syvorotkin A.N. More efficient resource potential usage of high productive coal mines based on the production processes standardization. [Povyshenie effektivnosti ispolzovaniya resursnogo potentsiala vysokoproizvoditelnykh ugolnykh shaht na osnove standartizatsii proizvodstvennyh protsesov] ph.d. thesis in tehn. sciences. Moscow, 2004, 120 p.

2. Kilin A.B. Organization structure of the coal mines as the decomposed functionality of its director. [Orgstruktura ugledobyvayushchego predpriyatiya kak dekompozirovannyy funktsional ego rukovoditelia] GIAB-MIAB, 2014, №2, S.18-29.

3. Dobrovolsky A.I, Feofanov G.L., and Shivyryalkina O.S. Developing certification of the managers of "Urgalugol". [Razvivayushchayz atestatsia upravliayushchego personala OAO "Urgalugol"] Ugol-Coal, 2013, № 3, S.104-109. 


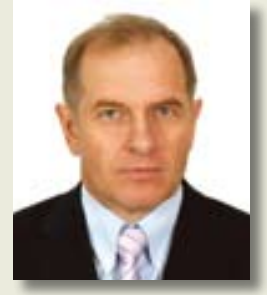

БУЙнИЦкИЙ

Александр Иванович

Первый заместитель исполнительного директора

ЗАО «Разрез Березовский»

г. Шарыпово, Россия,

e-mail:Priemnaja@suek.ru

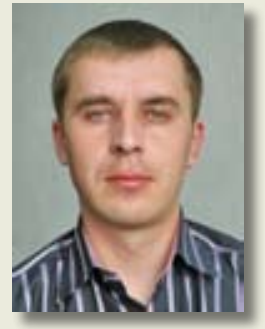

\section{ГОРЖИЙ}

Роман Юрьевич

Экономист

ЗАО «Разрез Березовский»

г. Шарыпово, Россия
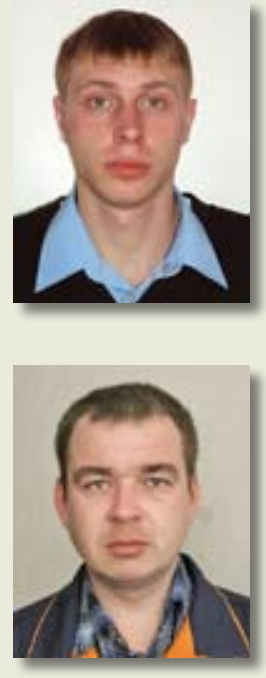

\section{ЖУРАВКОВ}

Роман Александрович

Электромеханик ЦРМГО

ЗАО «Разрез Березовский»

2. Шарыпово, Россия

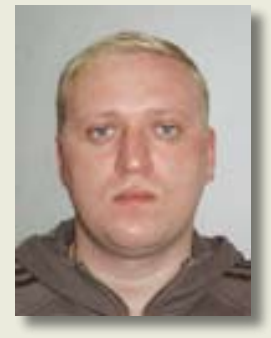

МАРТЮШЕВ

Сергей Анатольевич

Электрослесарь ЦКТ

ЗАО «Разрез Березовский»

2. Шарыпово, Россия

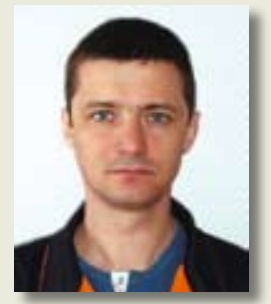

\section{ПОЛЕВОЙ}

Роман Александрович

Начальник участка

брикетного производства

ЗАО «Разрез Березовский»

г. Шарыпово, Россия

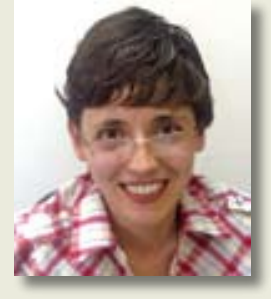

\section{ПОЛЕЩУК}

Марина Николаевна

Научный сотрудник

ООО «НИИОГР»,

канд. экон. наук,

г. Челябинск, Россия

e-mail:m_poleshuk@mail.ru

\section{Разработка норм организации рабочего процесса}

\section{«ремонт и замена конвейерной ленты»}

\begin{abstract}
Приведены результаты разработки норм организации процесса, осуществленной в рамках семинара с заместителями директоров по производству.
\end{abstract}

Ключевые слова:организачия, норма, ремонт, рабочий прочесс, конвейерная лента.

Уникальность двух предприятий энергетического комплекса Березовской ГРЭС и разреза Березовский, заключается в том, что уголь с экскаваторного забоя по цепочке конвейеров КЛ-5250, КЛМ-4500 общей протяженностью 18 км поступает непосредственно на комплекс системы топливоподачи станции. При такой технологической схеме отгрузки угля потребителю значительно возрастают требования к надежности работы транспортного оборудования разреза, сокращению сроков его простоя при выполнении ремонтных и регламентных работ.

Работа в данном направлении ведется. По нормам 2007 г. на процесс ремонта и замены ленты (на 1 стык) требовалось затратить 235 чел. -ч, а в 2014 г. трудозатраты на ремонт ленты составляют 96 чел-ч.

Учитывая ожидаемое увеличение отгрузки угля на БГРЭС на 22,5 млн т в связи с вводом третьего энергоблока, а также старение ленты (большая часть установлена в 1987-1989 гг.), сокращение времени, затрачиваемого на процесс замены и ремонт конвейерной ленты, становится серьезным и основным организационным фактором, который влияет на техническую готовность и эффективность работы всего разреза, и конвейеров в частности. Поэтому требуется дальнейшее улучшение процесса ремонта.

Для разработки и освоения норм организации процесса ремонта руководством разреза была создана рабочая группа из достаточно квалифицированных и перспективных работников цеха ремонта и монтажа горного оборудования (ЦРМГО), цеха конвейерного транспорта (ЦКТ) и экономиста разреза, и направлена в целевую командировку в НИИОГР, г. Челябинск.

При разработке норм группа исходила из того, что нормы должны быть в основе планирования, подготовки, организации осуществления процесса, а также оценки использования труда на предприятии. Они должны учитывать производственные условия и реализуемую компанией стратегию развития $[1,2,3,4,5]$.

Для формирования модели рационального производственного процесса ремонта и на ее основе разработки проекта норм на подготовку и осуществление этого рабочего процесса были проведены хронометражные наблюдения за процессом, выделены основные операции и построен график фактического осуществления процесса. Это позволило выявить резервы дальнейшего снижения трудозатрат и сокращения сроков ремонта.

Оценка возможностей совмещения операций и расстановки персонала, а также проработка технико-технологических реше- 


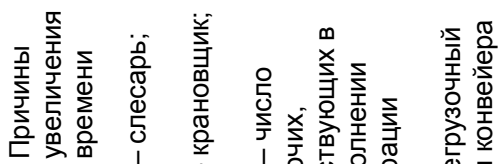

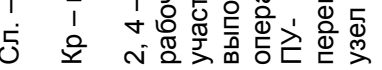

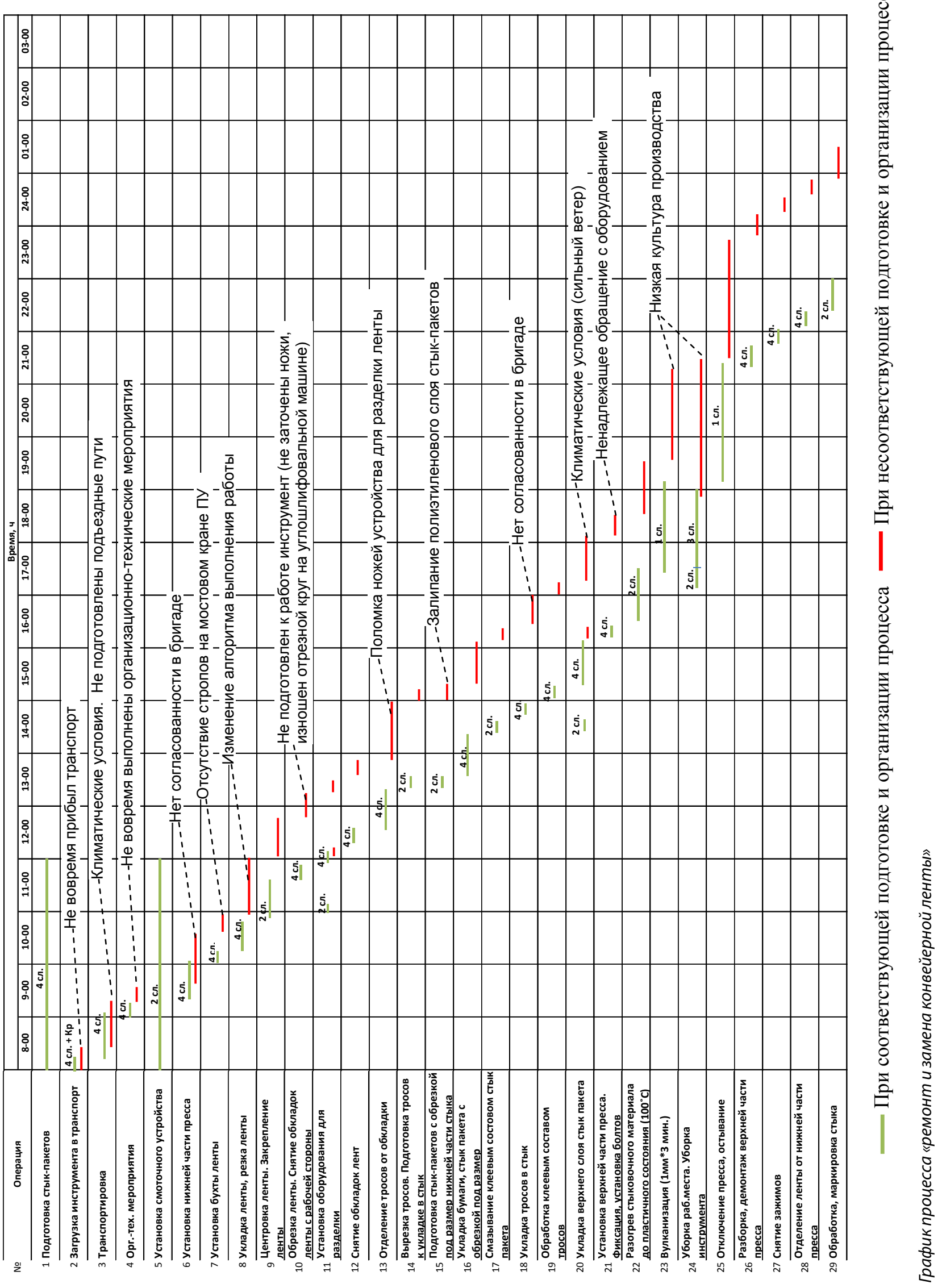


Дальнейшим шагом в работе является опробование разработанных норм организации процесса ремонта. Для этого необходимы соответствующие подготовка и организация труда как ремонтной бригады ЦРМГО, так и персонала ЦКТ, обслуживающего перегрузку, и АТЦ, обеспечивающего транспортом и отвечающего за состояние дорог. Кроме того, целесообразно вести ежесменную диагностику и учет состояния ленты.

Одновременно с работой группы в НИИОГР проводился семинар с заместителями директоров по производству, которые активно предлагали улучшение норм. Важные результаты, полученные в ходе обсуждений, для нашей группы следующие:

- взаимосвязь показателей «Ритмичность $\rightarrow$ Безопасность $\rightarrow$ Эффективность»;

- необходимость вести еженедельный, ежесуточный анализ удельных затрат для управления эффективностью;

- оплата за объемы, а не за качество выполняемых работ приводит к увеличению лишней работы и снижению качества результата;

- по графикам можно отслеживать проделанную работу даже в секундах.

\section{PЕЗЮME}

По итогам семинара был разработан проект норм организации производственного процесса ремонта и замены конвейерной ленты, использование которого на разрезе «Березовский» может позволить снизить трудозатраты на осуществление ремонта в 2,2 раза, а время ремонта сократить с двух до одной смены. Для успешного опробования и освоения норм необходима соответствующая система подготовки и организации труда как ремонтной бригады цеха ремонта и монтажа горного оборудования, так и персонала смежных цехов.

\section{Список литературы}

1. Азев В.А., Артемьев В.Б. Адресно ориентированное совершенствование систем планирования и организации производства на угольных разрезах // Уголь. 2012. №2. С. 50-52.

2. Возможности повышения эффективности производства при его стандартизации: отчет /ОАО «НТЦ-НИИОГР». Междуреченск, 2005.

3. Кулецкий В.Н., Артемьев В.Б. Формирование угольного разреза нового технико-технологического уровня // Уголь. 2013. №12. С. 72-75.

4. Лапаева О.А. Актуальные задачи совершенствования системы нормирования труда горнодобывающего предприятия // Проблемы управления социально-экономическими системами в условиях инновационного развития. Сб. науч. тр. VIII регион. науч. -практ. конференц. (Ч. I) и XXXVIII студенческой конференции «Студент и научно-технический прогресс» (Ч. ІІ) (Челябинск, март 2014 г., апрель 2014 г.) / Челяб. гос. ун-т. Челябинск: Энциклопедия, 2014. C. 208-214.

5. Яблонских Н.В. Совершенствование системы нормирования производственных ресурсов в управлении угледобывающим предприятием: Дис.... канд. экон. наук. Челябинск, 2007. 128 с.

UDC 658.387:658.155:622.33.012.3:622.682:621.867.2.004.67 @ A.I. Buynitskiy, R.Y. Gorjiy, A.A. Grigoriev,

R.A. Zhuravkov, S.A. Martushev, R.A. Polevoy, M.N. Poleshchuk, 2014

Title

DEVELOPING NORMS FOR THE “CONVEYOR BELT REPAIRING AND REPLACEMENT" WORKFLOW

Authors

Buynitskiy A.I., Gorjiy R.Y., Grigoriev A.A., Zhuravkov R.A., Martushev S.A., Polevoy R.A., Poleshchuk M.N.

\section{Authors' Information}

Buynitskiy A.l., first deputy of executive director of "Razres Berezovskiy" CC, Sharypovo, Russia, e-mail: Priemnaja@suek.ru

Gorjiy R.Y., economist of "Razres Berezovskiy" CC, Sharypovo, Russia

Grigoriev A.A., master of TSRMGO of "Razres Berezovskiy" closed company, Sharypovo, Russia

Zhuravkov R.A., electrician of TSRMGO of "Razres Berezovskiy" CC, Sharypovo, Russia

Martushev S.A., wireman of CKT of "Razres Berezovskiy" CC, Sharypovo, Russia

Polevoy R.A., section engineer of briquette production of "Razres Berezovskiy" CC, Sharypovo, Russia

Poleshchuk M.N., research engineer of "Scientific-research institute of efficiency and safety of mining" Itd., ph.d in Economics,

e-mail: m_poleshuk@mail.ru

\section{Abstract}

The results of organization standards development are presented in the paper, carried out at the seminar with the deputy operational director.

\section{Keywords}

Organization, Norm, Repair, Workflow, Conveyor Belt.

\section{References}

1. Azev V.A., and Artemyev V.B. Address-oriented improvement of planning and production organization systems at coal mines. [Adresno-orientirovannoe sovershenstvovanie system planirovaniya I organizatsii proizvodstva na ugolnykh razrezah] Coal, 2012, №2, S.50-52.

2. Opportunities for improving the production efficiency with its standardization. [Vozmozhnosti povysheniya effektivnosti proizvodstva pri ego standartizatsii] Otchet "NTC-NIIOGR" Itd. — Report of STC SRIESM, Mezhdurechensk, 2005.

3. Kuletskoy V.N., and Artemyev V.B. Forming the coal mine of new technological level. [Formirovanie ugolnogo razreza novogo tehniko-tehnologicheskogo urovniya] Ugol-Coal, 2013, №12, S.72-75.

4. Lapaeva O.A. Crucial tasks for improving the labor regulation system of mining enterprise. Problems in the management of socio-economic systems in terms of innovative development. [Aktualnye zadachi sovershenstvovaniya sistemy normirovaniya truda gornodobyvayushchego predpriyatiya. Problemi upravliniya sotsialno-ekonomicheskimi sistemami v usloviyahinnovatsionnogo razvitiya] Coll. scientific. works VIII region. scientific and practical. conference and XXXVIII Student Conference "Student and Scientific-Technical Progress", Chelyabinsk, March, April 2014 Chelyabinsk, Encyclopedia, 2014 S.208-214. 5. Yablonskikh N.V. Improving the production resources standardization system in the management of coal mining enterprises. [Sovershenstvovanie sistemy normirovaniya proizvodstvennykh resursov $v$ upravlenii ugledobyvayushchem predpriyatii] ph.d. thesis in econom. sciences. Chelyabinsk, 2007, 128 p. 
В НИтУ «МИСиС» ведущие ученые и эксперты горнопромышленной отрасли обсудили с руководством университета перспективы развития горного образования в России: новые образовательные программы, эффективные методы и средства обучения, формирование бренда Горного института.

В. Л. Петров, А. А. Черникова, Л. А. Вайсберг (слева-направо)

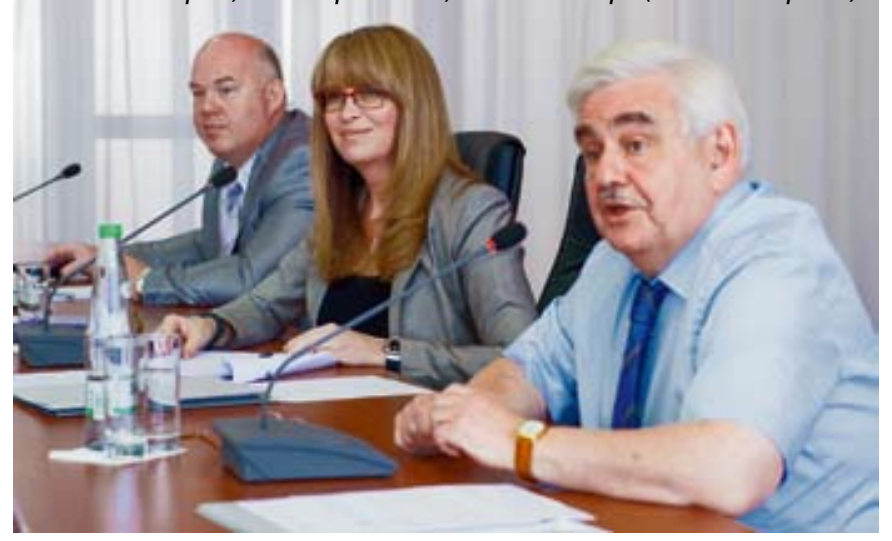

Ректор НИТУ «МИСиС» Алевтина Черникова начала обсуждение с подробного рассказа о развитии университета с момента объединения с Московским Горным, а затем попросила экспертов поделиться своим видением на развитие горного образования, обсудить кадровые проблемы горнопромышленной отрасли, выразить свою точку зрения на то, какие шаги и меры стоит обязательно предпринять в МИСиС, чтобы привлечь в Горный институт талантливую молодежь.

К разговору были приглашены лучшие ведущие эксперты и ученые отрасли: Юрий Малышев (директор Государственного геологического музея им. В.И. Вернадского РАН, академик РАН), Леонид Вайсберг (председатель Совета директоров и научный руководитель НПК «Механобр-техника»), Георгий Краснянский (председатель Совета директоров ООО «Каракан инвест»), Валерий Захаров (директор ИПКОН РАН, профессор, доктор техн. наук), Климент Трубецкой (главный научный сотрудник ИПКОН РАН, академик РАН, советник Президиума РАН).

Создание новых образовательных программ и учебников в тесном сотрудничестве с бизнесом, проведение перспективных исследований на кафедрах и расширение их прикладной деятельности, создание совместных лабораторий с горнодобывающими консорциумами и законодательное закрепление статуса горного инженера - таковы, по мнению экспертов, лишь некоторые шаги, которые необходимы для возрождения престижа профессии специалиста горной отрасли.

$$
\text { *** }
$$

Первым выступил Леонид Вайсберг, председатель Совета директоров и научный руководитель НПК «Механобр-техника», который входит в международный научный совет НИТУ
«МИСиС»: «Мы должны сами научиться передавать свои знания молодежи с максимальной эффективностью. Мы должны работать с лучшими студентами, использовать современные методики и способы получения образования, формировать сообщество молодых инженеров-горняков, обменивающихся опытом не только на профильных конференциях, ноив постоянномонлайн-общениикакмеждусобой, так и сведущими экспертами. Нужно больще работать со школами, проводить профоринтационные мероприятия, олимпиады, популяризировать науку, прививать любовь к математике и физике с ранних лет, только тогда к нам придутучиться действительно замотивированные, начеленные получить хорошее образование студенты. Огромное внимание, на мой взгляд, нужно обратить на поддержку развития профильных научно-исследовательских школ в университете, созданию новых лабораторий. Я принимал непосредственное участие в обсуждении формирования дорожной карты Горного института после присоединения кМИСиС. Уинститута сейчас, когда он может включиться в программу 5/100 вместе с МИСиС, есть огромный потенциал, чтобы стать институтом, выпускающим научную элиту, чтобы вернуть званию «горный инженер» былой престижи высокое уважение. Затем Леонид Вайсберг пригласил высказаться всех экспертов.

$$
* * *
$$

«Я буду сегодня говорить не как ученый, имеющий педагогический опыт, я расскажу вам о проблеме с позиций инвестора. Мы испытываем катастрофическую нехватку высококвалифицированных сотрудников вобласти горной промышленности, тот малый процент выпускников вузов, что приходят в отрасль, не владеют достаточными знаниями, чтобы сразу начать работать с современной техникой, чтобы сразу производить сложные расчеты. Всех приходится учить с самого начала! Это неправильно! Именно вуз должен готовить специалистов, у которых мы, старшее поколение, будем спрашивать совета! Ha мой взгляд, проблема в устарелых учебных программах

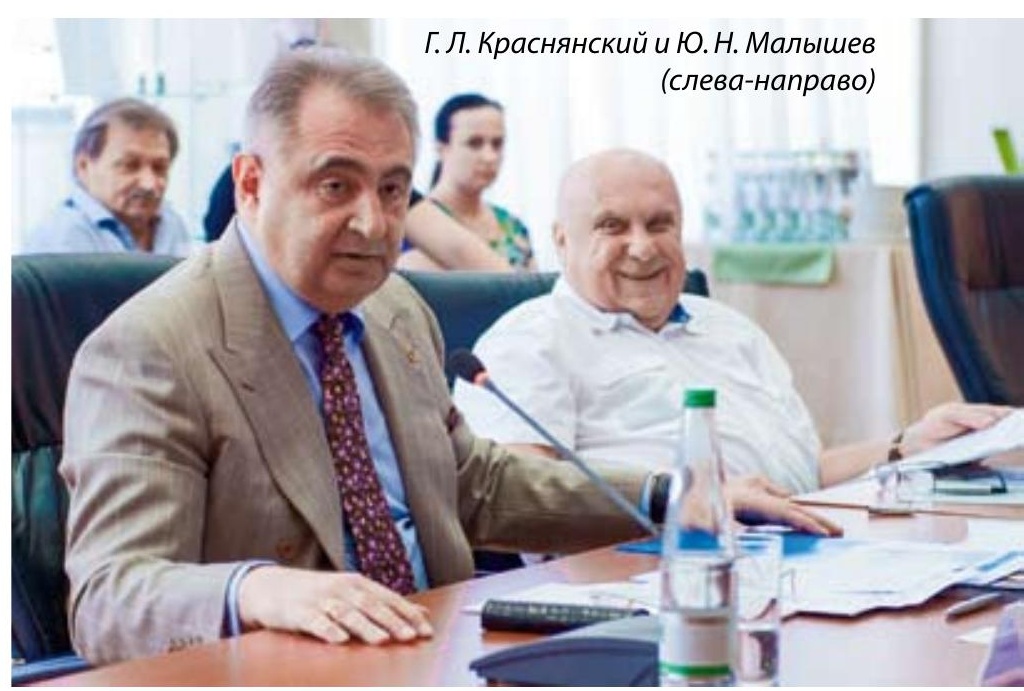


горного образования. Их нужно пересмотреть и обновить в соответствии с реалиями действительности! Я готов сам выделить время и средства, чтобы свозить экспертов непосредственно на горнопромышленные объекты, тогда программа будет подразумевать формирование у студентов хороших прикладных навыков. Я готов учредить стипендию лучшим студентам Горного института, готов поддерживать таланты со 2-3 курса, преподавать, вывозить на практику, чтобы после получения диплома МИС СС, сразу принять на работу новое поколение горных инженеров с глубоким пониманием предмета, а главное, способных с экономической точки зрения взглянуть на любой проект. Это очень важное умение, оно помогает экономить большие деньги, следить за охраной окружающей среды, поддерживать социальный статус работни ков отрасли! Горный институт - моя alma mater, я хочу участвовать в возрождении Московской научной школы горняков, сказал Георгий Краснянский, председатель Совета директоров ООО «Каракан инвест», промышленного холдинга, занимающегося разработкой Караканского угольного месторождения (Кемеровская обл.).

$$
\text { *** }
$$

Юрий Малышев, директор Государственного геологического музея им. В.И. Вернадского РАН, указал на необходимость ранней профориентации школьников для работы в горной отрасли, а также ряд шагов по законодательному закреплению статуса инженера-горняка: «Важно с первых классов школ в доступной форме, например, с помощью тех же комиксов, рассказывать ребятам о захватывающей профессии горного дела. У себя в музее мы проводим удалённые видеоэкскурсии и профориентационные лекции, что позволяет общаться с детьми напрямую, получать и давать обратную связь. МИСиС необходимо работать со студентами из региональныхпрофильных вузов, вывозить ихна стажировку в Москву, помогать включаться в горную наукурядом свыдающимисяучеными. Анагосударственном уровне стоит задача разработки и утверждения статуса горного инженера, наделения его определённым социальным пакетом, зарплатой, возможно, квартирой на месте работы. Нашей экспертной группой разработан проект такого статуса.Данный комплексмер позволит укрепить престиж профессии горного инженера, вернёт талантливую молодежь в отрасль, позволит отойти от ситуации последних лет, когда новоиспечённые выпускники по теме угольнойразработкинеидутработатьпоспециальности».

$$
* * *
$$

Профессор, доктор техн. наук Валерий Захаров, директор ИПКОН РАН еще раз подчеркнул необходимость организации большего количества олимпиад по математике и физике: «Без хороших знаний по этим предметам, у будущих студентов не получится стать специалистами отрасли, поэтому работать надо начинать со школьниками. Вуниверситетахнеобходимо развитие современных тренажёрно-аппаратныхкомплексов, которые позволяли бы обучать людей эффективно до их прихода на производство, давали бы живое понимание того, с чем будущим специалистам предстоuт работать, чтобы как у летчиков и врачей, не допускать к практике спечиалистов без полноценного освоения работы на тренажере. Это поможет и студентам и преподавателям глубже понимать предметы! Это поможет выпускать специалистов горного дела нового уровня подготовки».

$$
\text { *** }
$$

Живое обсуждение длилось более 3-х часов, эксперты и сотрудники МИСиС обсуждали все новые и новые аспекты развития Горного образования в России, обменивались мнениями, делились своим опытом и опытом зарубежных коллег. В ходе заседания удалось обозначить ряд основных проблем, решение которых поможет выпускникам горных специальностей стать востребованными высококвалифицированными специалистами во всем мире.

$$
* * *
$$

Итоги круглого стола подвели модераторы встречи ректор НИТУ «МИСиС» Алевтина Черникова и член международного научного совета НИТУ «МИСиС» Леонид Вайсберг.

«Уважаемые эксперты, уважаемые коллеги! Прежде всего, благодарю вас за живую беседу, советы, мнения. Все, что сегодня обсуждалось на нашем Круглом столе, мы детально разберем на методическом и научном советах. Мы подумаем, как можно модернизировать кафедры и какое техническое оснащение требуется Горному институту, чтобы студенты моглизаниматься полноценной научно-исследовательской деятельностью. Студенты Горного института начнут, каки все студенты МИСиС, изучать английский язык по совместной программе разработанной преподавателями МИСиС и Кембриджским университетом. По окончании обучения все студенты проходят внешнее тестирование, алучшие получают международный сертификат IELTS. Это дает им возможность продолжить обучение на англоязычныхмагистерских программах в НИТУ «МИСИС», a также в другихроссийскихи зарубежныхуниверситетах, обратилась к присутствующим Алевтина Черникова. «Эта встреча говорит о том, что мы идем в правильном направлении, ваши советы и предложения помощи ворганизации учебной и научной деятельности в Горном институте - бесценны. Ректор предложила через некоторое время встретиться и рассмотреть какие из высказанных предложений реализуются. «Мы открыты для ваших пожеланий, открыты для новых проектов», - подытожила ректор.

«Сегодня задача флагмана горного образования России, Горного института в составе НИТУ «МИСИС», это определить новые точки роста компетениий, в которых институт мог бы стать максимально конкурентоспособным как на рынке образовательных услуг, так и в науке. Таких направлений может быть 3-4, они могут касаться тем нефтегазовой отрасли, горной робототехники и р. Сегодня с вхождением в состав НИТУ «МИСИС» Горный институт получает возможность ренессанса, открытия второго дыхания, когда пришло время определить новые прорывные направления деятельности. Московский горный институт снова должен стать базовой образовательной площадкой для подготовки элиты горного дела, какэто и было раньше. На мой взгляд, наша основная задача - повысить уровень исследовательской работы Горного института.Иконечно для этого необходимо привлекать больше экспертов из-за рубежа, поднимать науку, находится в постоянномдиалоге сработодателями, чтобы реагировать на любые изменения отрасли», — сказал Леонид Вайсберг. 
НИТУ «МИСиС»- это ведущий научно-образовательный центр страны по подготовке специалистов в области металлургии, материаловедения, горного дела, ІТ-технологий, нанотехнологий. На данный момент в состав Университета входит 9 институтов. Объединенная численность студентов, включая четыре филиала, — около 15000 чел. и около
3500 сотрудников, 1500 из которых представляют преподаватели и научные сотрудники. В 2013 г. НИТУ «МИСиС» стал победителем конкурса повышения конкурентоспособности российских университетов (программа «5/100»). В этом году Университет вошел в топ-100 авторитетного мирового рейтинга «QS» (страны BRICS).

\section{НИТУ «МИСиС» развивает успешное сотрудничество с ведущим мировым разработчиком информационных горно-геологических систем}

6 октября 2014 г. в новом учебном классе Горного института НИТУ «МИСиС» состоялся первый научный семинар. Ведущие российские и зарубежные специалисты в области геологии и горного дела обсудили актуальные вопросы геологоразведки и добычи полезных ископаемых на месторождениях угля, золота и урана.

Оборудование учебного класса, программное обеспечение и услуги по технической поддержке более чем на 1,5 млндол. США Горному институту безвозмездно предоставила австралийская компания Micromine в рамках совместного проекта с НИТУ «МИСиС». Отметим, что сотрудничество компании с университетом носит социально-образовательный характер. Цель - подготовить перспективные кадры для развития российской горнодобывающей промышленности, способные свободно ориентироваться в работе современных специализированных информационных систем.

«Наш университет заинтересован в подготовке специалистов, владеющих новейшими инструментами и программами в горно-металлургической отрасли. Новое программное обеспечение поможет нашим студентам не только систематизировать и лучше усвоить полученные теоретические знания, но и научиться ре- шать практические задачи в области проектирования, моделирования и контроля на горном производстве, отметила ректор НИТУ «МИСиС» Алевтина Черникова. - Кроме того, студенты, успешно закончившие курс обучения Micromine, получат сертификаты международного образиа».

«Сегодняучащимсягорныхспециальностей просто необходимознание современных специализированных программных комплексов - это очень важно для последующего успешного трудоустройства, - объяснил гендиректор российского филиала Micromine Борис Курцев.

Благодаря сотрудничеству НИТУ «МИСиС» и компании Micromine российские предприятия в перспективе смогут привлекать на работу хорошо подготовленных высококвалифицированных сотрудников, уже освоивших сложные горно-геологические программы и системы. На горнодобывающих предприятиях России и стран СНГ сегодня активно используется минимум пять видов специализированного ПО от различных производителей. Но эти системы во многом идентичны, поэтому, изучив один программный продукт, специалист может быстро разобраться и в других. Переобучение дается, как правило, значительно проще, чем освоение программ с нуля.

\section{В НИТУ «МИСиС» успешно завершился первый этап проекта президентской программы повышения квалификации красноярских горняков}

17 октября 2014 г. в НИТУ «МИСиС» успешно завершился первый этап масштабного образовательного проекта в рамках президентской программы по повышению квалификации инженерных кадров.

В рамках проекта НИТУ «МИСиС» успешно провел семинар «Методы оптимизации использования горной техники на открытых горных работах в целях снижения энергозатрат на выемку единицы горной массы» для 15 специалистов компании СУЭК, работающих на горнодобывающих предприятиях Красноярского края. Семинар проходил с 1 сентября по 17 октября и включал в себя обучение объемом 72 ч теоретической подготовки. После окончания обучения, заполняя анкету слушателя, многие красноярские горняки выразили желание продолжить повышение квалификации в магистратуре и аспирантуре МИСиС.

Напомним, что в апреле этого года в рамках реализации дополнительных образовательных программ повышения квалификации НИТУ «МИСиС» выиграл конкурс Минобрнауки России на реализацию дополнительных образовательных программ в рамках президентской программы по повышению квалификации инженерных кадров. Президентская программа повышения квалификации инженерных кадров включает в себя три этапа - обучение в НИТУ «МИСиС», стажировку в инжиниринговых / исследовательских центрах Германии, а затем стажировку в инжиниринговых / исследовательских центрах России. 


\section{Государственно-частное партнерство}

\section{путь к решению инновационных задач перевода систем шахтного водоотлива на использование композитных материалов}

Раскрывается комплексный подход по эколого-экономической оценке возможности организации перевода систем водоотведения шахт и карьеров на использование композитных материалов с возможностью инструментов государственно-частного партнерства. Обоснована целесообразность перехода на использование композитныхматериалов в системе карьерного водоотведения разреза «Черниговский».

Ключевые слова: системы карьерного и шахтного водоотведения, композитные материалы, инструменты государственно-частного партнерства.

В современных условиях одной из проблем при разработке угольных месторождений является проблема коррозионной стойкости и износостойкости систем водосбора и водоотведения шахтных и карьерных сточных вод.

Коррозия обусловлена высокой агрессивностью минерализованных шахтных и карьерных вод, их высокой кислотностью, наличием в них механических примесей и содержанием тяжелых металлов [1, 2]. В угольной промышленности на некоторых предприятиях срок службы труб на водоотливах при наличии кислых шахтных вод составляет всего несколько месяцев, поскольку кислотные шахтные воды их быстро разрушают. Такое положение дел приводит к загрязнению окружающей среды, в основном это происходит в результате аварий трубопроводов и водоотливного оборудования, подверженного коррозии.

В $95 \%$ случаев аварийные ситуации в системах водоотведения происходят на трубопроводах по причине коррозионных поражений внутренней поверхности.

Одним из направлений решения рассматриваемой проблемы в современных условиях является перевод систем шахтного и карьерного водоотведения на использование полимерных композиционных материалов. Полимерные композиционные материалы (ПКМ) имеют высокую стойкость к коррозии, а также стойкость к различным агрессивным химическим соединениям. Использование ПКМ может существенно повысить срок службы трубопроводов и оборудования систем отвода шахтных, карьерных и сточных вод.

Системы водоотведения из ПКМ не подвержены климатическим изменениям и коррозионному износу (соответственно будут исключены протечки), требуют минимального обслуживания и ремонта в течение срока эксплуатации. Кроме вышеперечисленных достоинств данные системы из ПКМ будут иметь и гораздо меньший физический вес, чем металлические, что упрощает монтаж, особенно в труднодоступных районах.

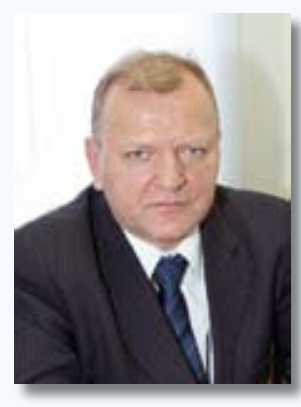

ЕФИМОВ

Виктор Иванович

Заместитель

генерального директора

по инновациям и науке

ОАО ХК «СДС-Уголь»,

профессор, доктор техн. наук

г. Кемерово, Россия,

e-mail:v.efimov@mirtrade.ru, тел.: +7 (926) 779-98-17

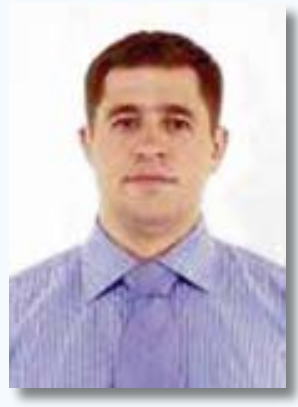

\section{КОНОВАЛОВ}

Дмитрий Викторович

Руководитель проектов

OAO «MMЭ3-KT»

Москва, Россия,

e-mail:d_konovalov@mempct.ru, тел.: +7 (499) 256-62-22

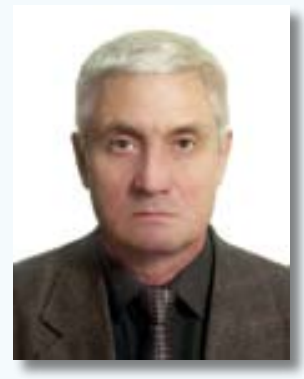

\section{ПоПов}

Сергей Михайлович

Профессор кафедры

ЭГП НИТУМИСиС

Москва, Россия,

e-mail: s.popov@inbox.ru,

тел.: +7 (916) 858-55-10

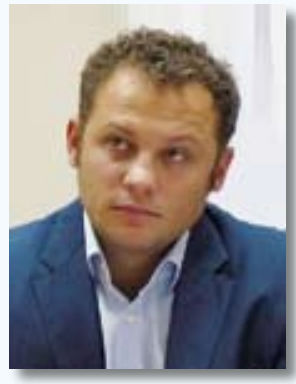

\section{ФЕДЯЕВ}

Павел Михайлович

Магистрант МИГСУ РАНХИГС

Москва, Россия,

e-mail:Fpm@sds-alko.ru,

тел.: +7 (495) 721-83-53 


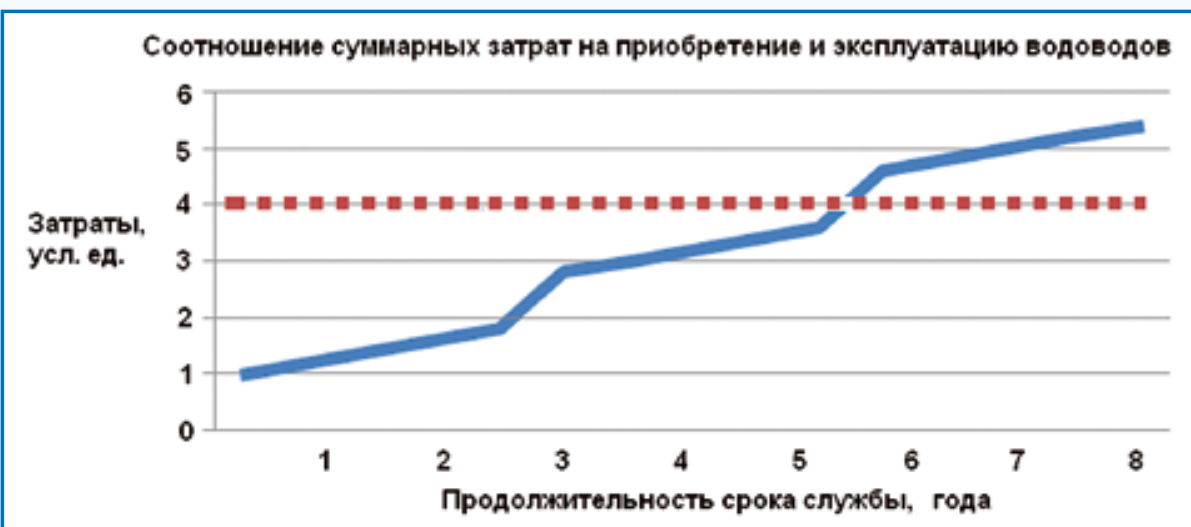

=Суммарные затраты на созданне и экслуатацио водовода из металччески труб

" = " " = " Суми арные затраты на создание и эксплуатацию водовода их композиных тру6

Puс. 1. Соотношение суммарных затрат на создание и эксплуатацию

водоводов карьерных и шахтных вод из металлических и композитных материалов

В настоящее время затраты горнопромышленных компаний на рациональное природопользование исчисляются миллиардами рублей в год. Большая часть их направляется на капитальный ремонт трубопроводного транспорта, а также осуществление его ингибиторной защиты; на строительство и реконструкцию систем отвода шахтных, карьерных и сточных вод, на очистку загрязненных грунтовых вод из дренажных систем, модернизацию действующих и строительство новых очистных сооружений.

Большинство угледобывающих компаний несут большие издержки в связи с коротким сроком службы и общим высоким уровнем износа систем трубопроводов, технологического оборудования и трубопроводной арматуры. В этой ситуации становится очевидной целесообразность проведения комплексной эколого-экономической оценки возможности перевода имеющихся систем водоотведения на использование современных полимерных композитных материалов.

В основе сравнительной эколого-экономической оценки целесообразности перевода на использование композитных материалов систем водоотведения карьерных и шахтных вод лежит сравнительная оценка суммарных затрат угледобывающих предприятий на покупку, прокладку и обслуживание этих систем на весь период их функционирования при разработке месторождения [3].

В соответствии с имеющимся опытом эксплуатации различных материалов в системах водоотведения затраты на использование композитных материалов характеризуются относительно большим размером в начальный пе- риод времени в связи с их большей (в четыре-пять раз) стоимостью по сравнению со стоимостью металлических труб (рис. 1).

Однако в связи с тем, что в последующие периоды времени эксплуатационные затраты на обслуживание линий из композитных материалов несущественны и несоизмеримо меньше затрат на обслуживание линий из металлических труб, суммарные затраты оказываются намного меньше. Таким образом, можно сделать вывод о том, что определение эффективности перевода систем водоотведения на угледобывающих предприятиях с использованием композитных материалов должна быть основана на более углубленной оценке особенностей и условий для такой деятельности.

В этой связи был выполнен анализ эколого-экономических причинно-следственных связей (табл. 1), влияющих на снижение (рост) затрат угледобывающих предприятий при переводе систем водоотведения на использование композитных материалов [3].

В результате анализа причинно-следственных связей, влияющих на формирование производственно-экологических затрат угледобывающих предприятий при создании и эксплуатации линий водоотлива горнодобывающих предприятий на основе использования труб из металлических и композитных материалов, были выявлены следующие зависимости:

- формирование затрат горнодобывающего предприятия при развитии системы водоотлива с использованием труб из металла $\left(D^{1}\right)$ :

$$
D^{1}=\sum_{t} \sum_{i}\left(3_{t i}^{m}+3_{i t}^{o \sigma . m}+3_{t i}^{p e n}+r_{t i}\right) \frac{1}{(1+e) t},
$$

где: $i$ - индекс номера участка системы водоотлива; $t-$ индекс рассматриваемых периодов времени; $3_{t i}^{M}-$ затраты на покупку и монтаж металлических труб в системе

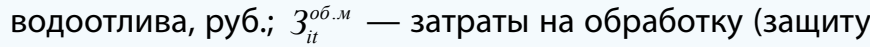
от коррозии) металлических труб в системе водоотлива, руб.; $3_{t i}^{\text {peм }}$ - затраты на ремонт изношенных коррозией металлических труб в системе водоотлива, руб.; $r_{t i}-$ затраты (платежи) на проливы карьерных ввод в результате коррозии металлических труб, руб.; е - средняя ставка кредитов коммерческих банков, доли единиц.

$$
3_{i t}^{\mu}=L_{i}\left(Ц_{i t}^{M}+C_{t i}^{\text {м.мон }}\right) \text {, }
$$

\section{Характеристика причин роста (снижения) расходов предприятия при переводе систем водоотведения с использования металлических труб на трубы из композитных материалов}

Причины снижения расходов

Снижение затрат на капитальный ремонт изношенной части линий водоводов

Снижение затрат на прокладку и монтаж линий водоводов

Снижение затрат на проведение антикоррозийного покрытия

Снижение затрат связанных с необходимостью выплат при авариях

за несанкционированное загрязнение среды

Снижение затрат на покупку новых металлических труб

\section{Причины роста расходов}

Прирост затрат на покупку труб из композитных материалов 
где: $L_{i}$ - длина участков системы водоотлива горнодо-

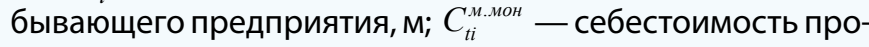
кладки и монтажа металлических труб, руб./м; $Ц_{i t}^{\mu}$ — цена металлических труб, руб. /м.

$$
r_{i t}=\sum_{t} W_{i t} N_{t},
$$

где: $r_{t}$ - годовой платеж за сверхнормативное загрязнение ОПС, руб. /м³ $W_{i t}$ - объемы проливов карьерных вод в результате коррозии метала, $\mathbf{m}^{3} ; N_{t}$ - нормативы платы за сверхнормативное загрязнение ОПС, руб. /мі;

- формирование затрат горнодобывающего предприятия при развитии системы водоотлива с использованием труб из композитных материалов $\left(D^{2}\right)$ :

$$
D^{2}=\sum_{t} \sum_{i}\left(Ц_{i t}^{\kappa}+C_{t i}^{\kappa . м о н ~}\right) L_{t i} \frac{1}{(1+e) t},
$$

где: $Ц_{i t}^{\kappa}$ — цена труб из композитных материалов, руб. /м; $C_{t i}^{\text {к.мон }}$ - себестоимость монтажа труб из композитных материалов, руб. /м;

- расчет экономического эффекта от замещения в системе шахтных металлических труб на изделия из композитных материалов:

- для горнодобывающего предприятия:

$$
\Im^{n p .}=D^{1}-D^{2}-C_{\kappa p} И^{\kappa}+D^{3} \text {, }
$$

где: $C_{\kappa p}$ - ставка платы за привлечение заемных (кредитных) средств для перевода системы водоотведения на инновационные технологии и материалы, руб.; $И^{\kappa}$ - размер привлекаемых инвестиций, руб.; $D^{3}$ - доход от высвобождения использовавшихся в системе водоотлива металлических труб, руб.

$$
D^{3}=\sum_{t} \sum_{i} L_{t i}^{\sigma \backslash y} \bigsqcup_{t}^{\sigma \backslash y} \frac{1}{(1-e) t},
$$

где: $L_{t i}^{\sigma \backslash y}$ - длина высвобождающихся бывших в употреблении металлических труб, м; $L_{t}^{\sigma \backslash y}-$ стоимость высвобождающихся бывших в употреблении металлических труб, руб. /м;

- для государства (прирост национального дохода):

$$
\Delta Н Д=D^{1}-D^{2} \text {. }
$$

Приведенная выше методика оценки целесообразности перевода систем водоотлива шахтных (карьерных) вод на использование композитных материалов позволяет оценить эколого-экономический эффект, который при этом может быть получен без учета реальных экономических условий, в которых в настоящее время находятся многие из горнодобывающих предприятий.

Однако, поскольку в условиях затяжного экономического кризиса большая часть предприятий угольной отрасли является низкорентабельной или даже убыточной, то, несмотря на экономическую эффективность внедрения инновационных преобразований в природоохранной сфере, без поддержки государства в настоящее время невозможно [4].

Поэтому в качестве одного из направлений, способствующих ускорению реализации достижений в сфере создания композитных материалов для транспортировки вод с повышенными кислотно-щелочными свойствами, предложено использовать инструменты государственно-частного партнерства (ГЧП). При разработке методических основ формирования инструмента ГЧП, позволяющего повысить эффективность перевода систем шахтного водоотлива на использование композитных материалов, были приняты следующие основополагающие методологические положения в этой области деятельности [5]:

- первое: современные системы шахтного водоотлива выполняют функции производственноэкологического значения, поскольку, с одной стороны, они призваны обеспечивать отвод вод от призабойного пространства, а с другой - осуществлять природоохранную деятельность по сбору, транспортировке до мест организованного сброса загрязненных вод в окружающую природную среду (ОПС) [6];

- второе: в случае роста аварийности систем шахтного водоотлива, в том числе, связанного и с ослаблением экономики горнодобывающих предприятий, неизбежны несанкционированные сбросы (проливы) шахтных вод в ОПС, ведущие к росту экологических платежей [7];

- третье: в решении вопросов снижения (предупреждения) загрязнения шахтными водами ОПС целесообразно нахождение компромиссов, позволяющих гармонизировать интересы государства и горнодобывающего предприятия [3];

- четвертое: в соответствии с вышеизложенным представляется вполне логичным предположение о возможности и целесообразности организовывать государственно-частное партнерство по внедрению высокорентабельных инновационных технологий в системы шахтного водоотлива, основанные на использовании композитных материалов, для реализации которых не требуется дополнительных расходов, как от государства, так и частных горнодобывающих компаний;

- пятое: в качестве основных инструментов такого партнерства в этой сфере может быть принято, с одной стороны, предоставление гарантий государственных органов (Минприроды) на погашение инвестируемых в этой сфере денежных средств в пределах суммы платежей, поступающих от горнодобывающих предприятий за загрязнение ОПС, а с другой - предоставление добывающему предприятию возможности осуществлять платежи по погашению инвестиций исходя из размера амортизационных отчислений на капитальный ремонт в системе отвода шахтных вод, которые имели место до перехода на инновационные технологии $[8,9]$.

Основываясь на положениях разработанного выше методологического подхода к решению задач по реализации инновационных технологий (использующих композитные материалы в сфере систем шахтного водоотлива) в современных экономических условиях, последовательность действий по организации использования инструментов государственно-частного партнерства в этой сфере деятельности представлена на рис. 2.

Приведенный механизм организации перевода систем шахтных водоотливов на новые инновационные технологии (базирующиеся на использовании композитных материалов), включающий в себя методические основы оценки эффективности такой деятельности с учетом инструмен- 


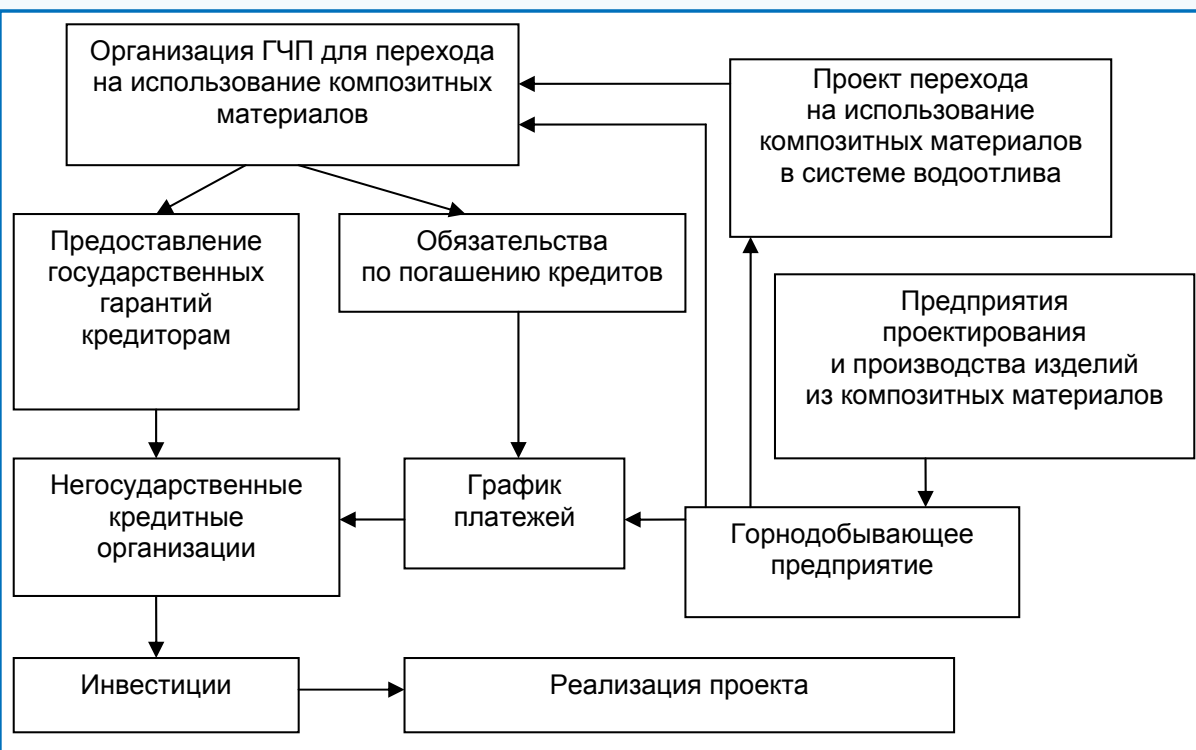

Pис. 2. Схема организации использования инструментов ГЧП

для реализации инновационных технологий в системах шахтного водоотлива ные планы по расширению и развитию производства. В соответствии с перспективами развития основных производственных процессов на разрезе «Черниговский» предусматривается в развитии линий карьерных водоводов перейти на использование металлических труб с диаметром 500 мм (табл. 2).

В результате проведения расчетов на основе предложенного выше методического подхода были определены суммарные затраты на создание и эксплуатацию линий карьерных стационарных водоводов на разрезе «Черниговский» для варианта, предусматривающего использование металлических труб, и варианта, предусматривающего использование труб из композитных материалов (рис. 3).

тов государственно-частного партнерства, позволяет не только перейти к практической реализации новаций в современных экономических условиях, но и осуществить их в кратчайшие сроки.

В качестве объекта для апробации методических разработок выбран разрез «Черниговский», добывающий высококачественные энергетические и коксующиеся угли открытым способом. В настоящее время запасов угля у ОАО «Черниговец», по подсчетам специалистов, должно хватить на 30 и более лет. Поэтому разработаны долгосроч-
Сравнительный анализ полученных значений суммарных затрат по рассматриваемым вариантам (см. рис. 3) позволяет сделать вывод о том, что использование композитных материалов при создании линий карьерного водоотлива на разрезе «Черниговский» является экономически наиболее предпочтительным. Применение композитных материалов с 2015 г. позволит разрезу начать экономить средства, которые ранее предполагалось отчислять для выполнения работ по ремонту линий водоводов из металлических труб, начиная с 2019 г. и

Таблича 2

\section{Характеристика перспективных планов развития системы водоотлива разреза «Черниговский»}

\section{Наименование}

Длина водовода сточных хозяйственно-бытовых вод, м Диаметр водовода сточных хозяйственно-бытовых вод, мм

Высота подъема сточных хозяйственно-бытовых вод, м

Длина водоводов хозяйственно-питьевого назначения, м

Диаметр водоводов хозяйственно-питьевого назначения, мм

Высота подъема хозяйственно-питьевых вод, м

Длина водовода карьерных вод выпуск №1, м

Длина водовода карьерных вод выпуск №2, м

Диаметр водовода карьерных вод выпуск №1, мм

Диаметр водовода карьерных вод выпуск №2, мм

Высота подъема карьерных вод выпуск №1, м

Высота подъема карьерных вод выпуск №2, м

Длина водовода карьерных вод выпуск №1, м

Длина водовода карьерных вод выпуск №2, м

Диаметр водовода карьерных вод выпуск №1, мм

Диаметр водовода карьерных вод выпуск №2, мм

Высота подъема карьерных вод выпуск №1, м

Высота подъема карьерных вод выпуск №2, м

Годовой износ в системе отвода карьерных вод, \%

Размер годовых амортизационных отчислений на капительный ремонт

в системе отвода карьерных вод, тыс. руб.

Годовой объем организованного сброса вод, тыс. мі

Годовой объем неорганизованного сброса вод, тыс. мі

Годовой размер платежей за сбросы загрязненных вод, тыс. руб.

Перспектива до 2020 г.

\section{Существующее положение}

Показатели
2300
$100-200,270$
Самотек
4000
100
40

4000

5000

325

325-500

170

280

5000

2500

500

500

350

300

7

28032

9825

0

130129
Материал

Металл, ПВХ

-

ПBX

$\mathrm{\Pi BX}$

-

Металл

Металл

Металл

Металл

Металл

Металл

Металл

Металл

Металл

Металл

Металл

Металл

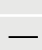




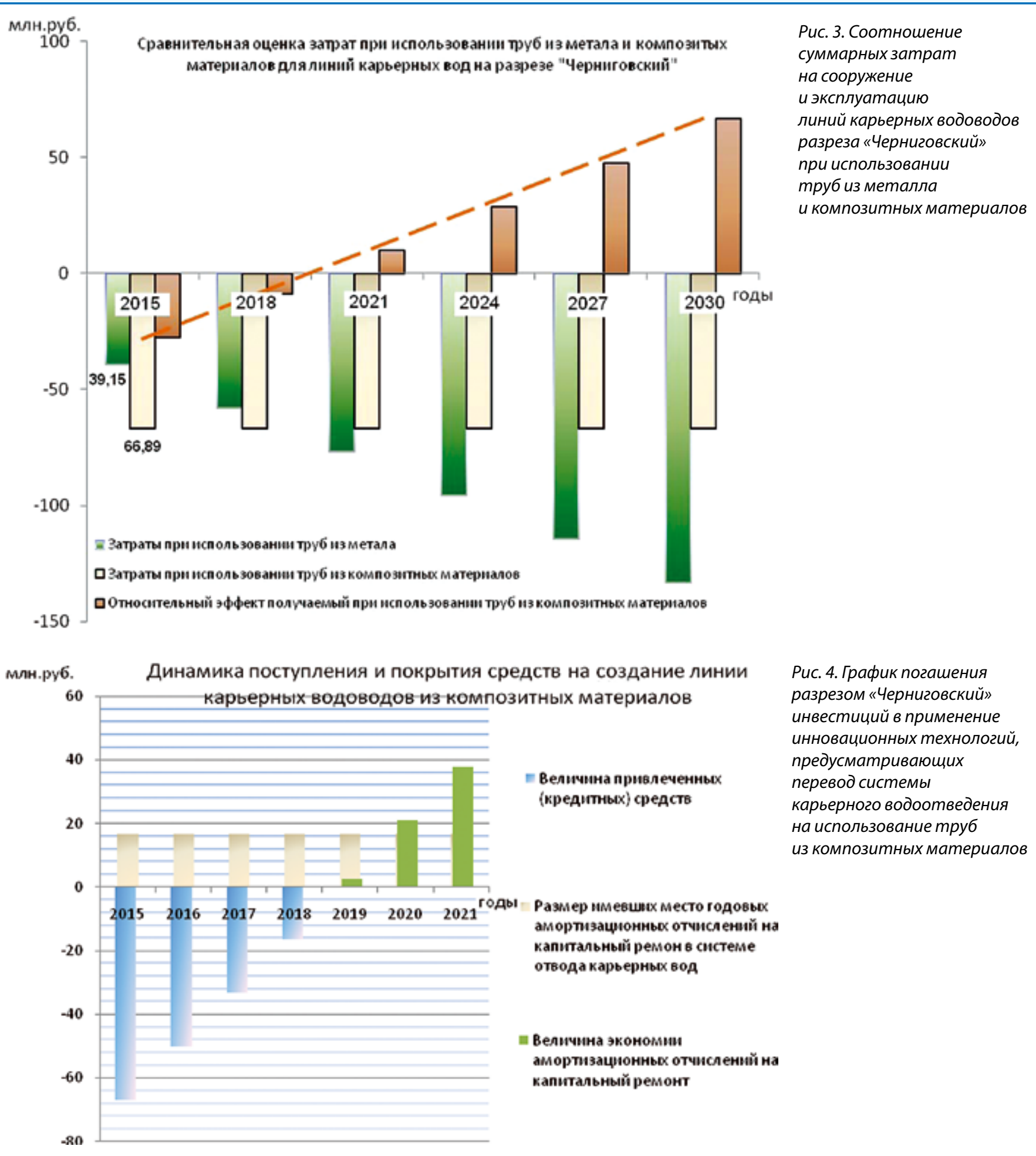

до конца срока отработки разрабатываемого участка месторождения.

В то же время из-за экономической неустойчивости работы разреза «Черниговский», вызванной падением цен на добываемый уголь, базирующейся на традиционных экономических инструментах привлечения инвестиций, перевод системы водоотведения на использование труб из композитных материалов затруднителен. Таким образом, для реализации инновационных технологий в этой сфере деятельности необходимо дождаться периода работы разреза на рынке с более благоприятными экономическими условиями, либо создать механизм, позволяющий обеспечить экономическую целесообразность для их осуществления в условиях экономического кризиса.

В соответствии с приведенным выше методическим подходом, в качестве механизма, позволяющего осуществить перевод системы водоотведения разреза «Черниговский», в современных условиях может быть использован инструмент государственно-частного партнерства.

В соответствии с приведенным выше механизмом ГЧП имеется возможность предоставления государственных гарантий на погашение инвестиций в размере 66,89 млн руб. (см. рис. 2) в применении инновационных техноло- 
гий, предусматривающих перевод системы карьерного водоотведения на использование труб из композитных материалов. Учитывая тот факт, что размер годовых амортизационных отчислений на капитальный ремонт систем водоотведения состоящего из предполагаемого объема замены металлических труб, составлял 16,03 млн руб., в организуемом ГЧП период погашения привлекаемых инвестиций составит около четырех лет (рис. 4).

\section{Выводы}

1. Отмечена актуальность решения проблемы снижения эколого-экономических издержек в системах водоотведения шахтных и карьерных вод, связанных с высокой коррозийностью используемых в них металлических труб.

2. Обоснована необходимость проведения комплексной оценки целесообразности перевода шахтных и карьерных систем водоотведения на использование композитных материалов.

3. Разработана методика оценки целесообразности перевода шахтных и карьерных систем водоотведения на использование композитных материалов.

4. Разработан методический подход по формированию инструментов государственно-частного партнерства для организации шахтных и карьерных систем водоотведения на использование композитных материалов.

5. Выполнена оценка целесообразности перевода системы водоотведения разреза «Черниговский» на использование композитных материалов.

\section{Список литературы}

1. Ефимов В.И. Ресурсы подземных вод Кузбасса // ГИАБ. 2006. №7. С. 173-177.

2. Гридин В. Г., Ефимов В.И., Поляков В. В. Состояние подземных вод Кузбасса // ГИАБ. Отдельный выпуск: Экологические проблемы Кузбасса. 2006. №2. С. 68-74.

3. Болдырев А. А., Попов С. М. Методические основы решения эколого-экономических задач на примере предприятий центра России // Горный журнал. 2007. №6. С. 29.

4. Экология «Природа и общество вопросы регулирования». Учебник / В.Г. Гридин, Т. Т. Исмаилов, А. Р. Калинин. М.: Издательство ООО «ТИД «Студент», 2011. 255 с.

5. Экономика, организация, управление природными и техногенными ресурсами / В.Г. Гридин, А.Р. Калинин, А. А. Кобяков. М.: Горная книга, 2012. 752 с.

6. Ефимов В.И., Рыбак Л.В. Загрязнение поверхностных вод Кузбасса // ГИАБ. Отдельный выпуск: Экология Кузбасса. 2007. №3. С. 21-34.

7. Производство и охрана окружающей среды: экологический, экономический и правовой аспект. Учебное пособие / В.И. Ефимов, А. В. Мясков, И. В. Петров и др. М., 2011.

8. Экономика природопользования. Учебное пособие / Н. М. Боднарук, А. А. Кобяков, Л. В. Рыбак и др. М., 2010.

9. Оценка потенциальных экологических последствий при проектировании консервации шахты / В.И. Ефимов, В.А.Гушинец, Р.В. Сидоров, Т. В. Корчагина // Уголь. 2014. №10. C. 100-104.

UDC 622.53:622.534:678.5/.6.003.1 @ V.I. Efimov, D.V. Konovalov, S.M. Popov, P.M. Fediaev, 2014 ISSN 0041-5790 • UGOL №11-2014/1064/

Title

PUBLIC-PRIVATE PARTNERSHIP IS THE WAY TO SOLVE THE PROBLEMS OF USING THE COMPOSITE MATERIALS IN THE WATER DRAINAGE SYSTEMS

\section{Authors}

Efimov V.I., Konovalov D.V., Popov S.M., Fediaev P.M.

\section{Authors' Information}

Efimov V.I., deputy director on innovations and science of "SDS-Ugol" JSC HC, professor, doctor of technical science, Kemerovo, Russia, e-mail: v.efimov@mirtrade.ru, tel.: +7 (926) 779-98-17

Konovalov D.V., project manager of "MMEZ-KT" JSC, Moscow, Russia, e-mail: d_konovalov@mempct.ru, тел.: +7 (499) 256-62-22

Popov S.M., professor of EGP department National Research Technological University, "Moscow Institute of Steel and Alloys", Moscow, Russia, e-mail: s.popov@inbox.ru, tel.: +7 (916) 858-55-10

Fediaev P.M., master's student of IIPAM RANERA, Moscow, Russia, e-mail: Fpm@sds-alko.ru, tel.: +7 (495) 721-83-53

\section{Abstract}

This paper presents the integrated approach on the ecological and economic evaluation of the possibility to organize the use of composite materials with the instrument possibility of public-private partnership for the water drainage systems in mines and open pits. The practicability of using of composite materials in the water drainage at the "Chernigov" open-cut mine has been proved.

\section{Keywords}

Career and Mine Water Drainage Systems, Composite Materials, Public-Private Partnerships Tools.

1. Efimov V. Groundwater resources of Kuzbass. [Resursy podzemnykh vod Kuzbassa] GIAB-MIAB 2006, №7, S.173-177.

2. Gridin V.G., Efimov V.I., and Polyakov V.V. Condition of Kuzbass groundwaters. [Sostoyanie podzemnyh vod Kuzbassa] GIAB-MIAB 2006, №2, S.68-74.

3. Boldyrev A.A, Popov S.M. Methodical base of ecological and economic problems solutions on the example of central Russia. [Metodologicheskie osnovy resheniya ekologo-economicheskih zadach na primere predpriyatiy tsentra Rosii] Gorny gurnal - Mining Journal, 2007, №6, C.29.

4. Gridin V.G., Ismailov T.T., and Kalinin A.R. Ecology "Nature and Society issues of regulation." [Ekologiya "Priroda I obshchestvo, voprosy regulirovaniya"] Textbook. Moscow, Publishing, LLC "TTI" Student", 2011, 255 p.

5. Gridin V.G., Kalinin A.R., and Kobyakov A.A. Economics, organization, management of natural and man-made resources. [Ekonomika, organizatsiaya, upravleniye prirodnymi I tehnogennymi resursami] Moscow Gornaya kniga - Mining book 2012, $752 \mathrm{p}$.

6. Efimov V.I, and Rybak L.V. Pollution of Kuzbass surface waters. [Zagriyazneniye poverhnostnyh vod kuzbassa] GIAB-MIAB 2007, №3, S.21-34.

7. Efimov V.I., Myaskov A.V., Petrov I.V. et al. Production and environment: ecological, economic and legal aspects. [Proizvodstvo I ohrana okruzhayushchey sredy: ekologicheskiy, ekonomicheskiy I pravovoy aspekt] Textbook. Moscow, 2011.

8. Bodnaruk N.M., Kabyakou A.A., Fisherman L.V. et al. Environmental Economics. [Ekologicheskaya ekonomika] Textbook. Moscow, 2010.

9. Efimov V.I, Gushinets V.A., Sidorov R.V., and Korchagin T.V. Evaluation of the potential environmental impacts when designing mine conservation. [Otsenka potentsialnyh ekologicheskih posledstviy pri proektirovanii konservatsii shahty] Ugol-Coal, 2014, №10, S.100-104. 


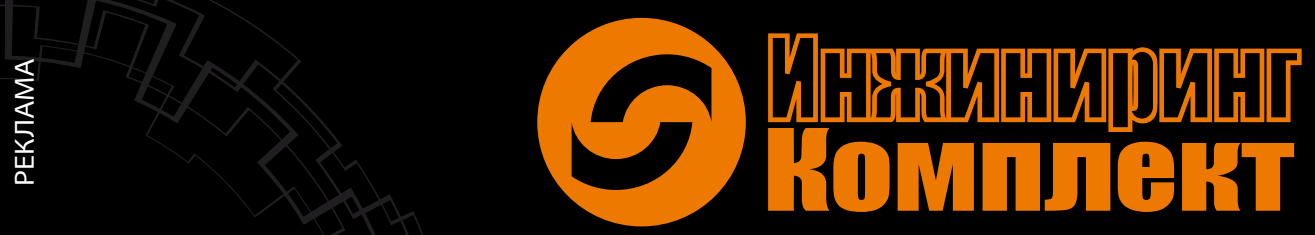

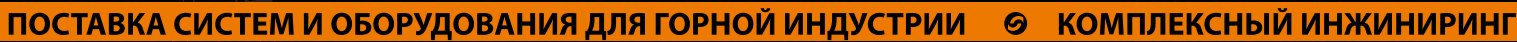

До 5 испытаний в год

Обособленных подразделений из регионов РФ и стран СНГ

Более 12000 наименований предлагаемого

оборудования из 17 стран мира

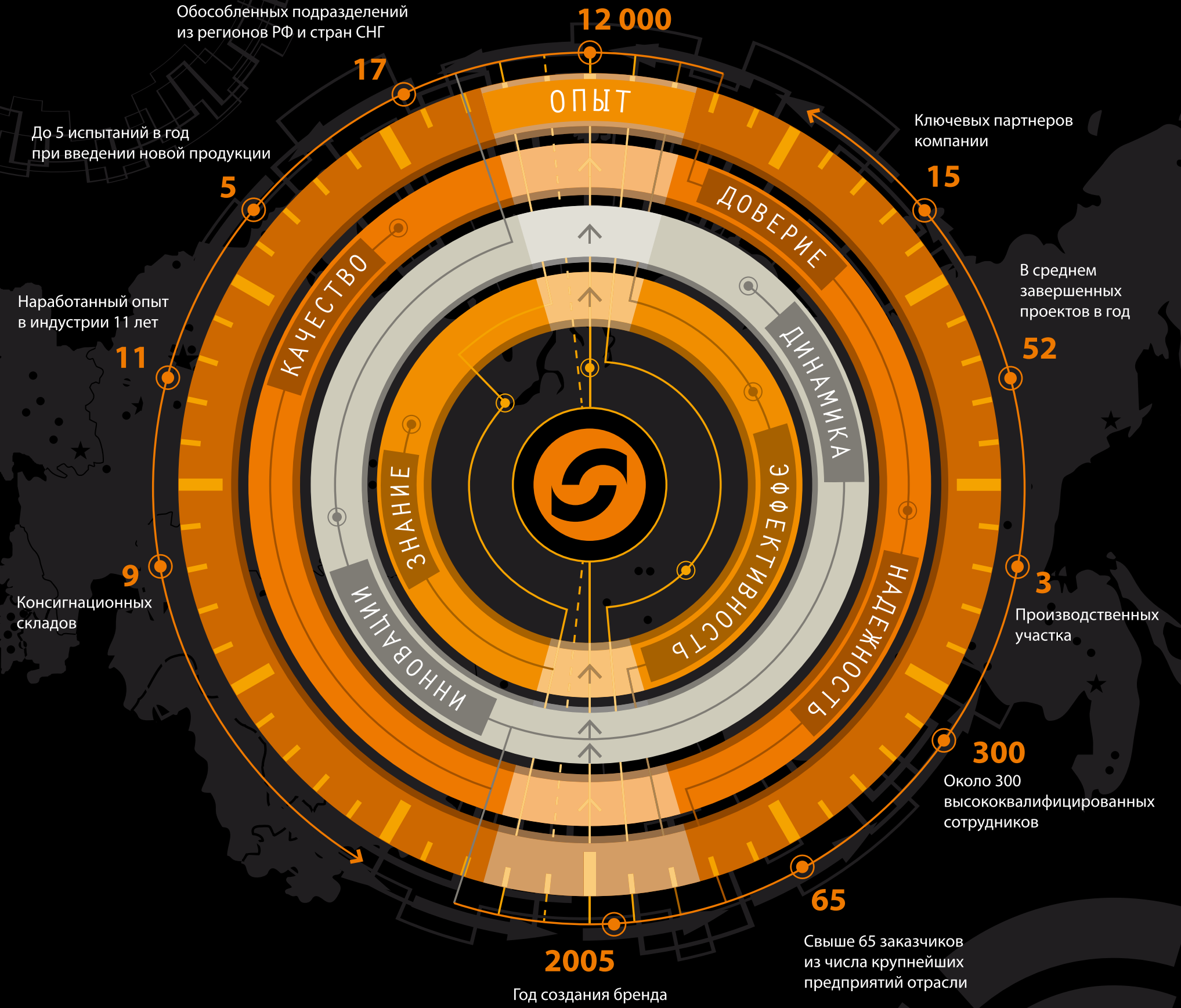

«Инжиниринг Комплект» - ведущий поставщик комплексных решений и услуг по инженерному проектированию, поставке и обслуживанию надежного оборудования для горнодобывающей, металлургической и энергетической промышленностей. 


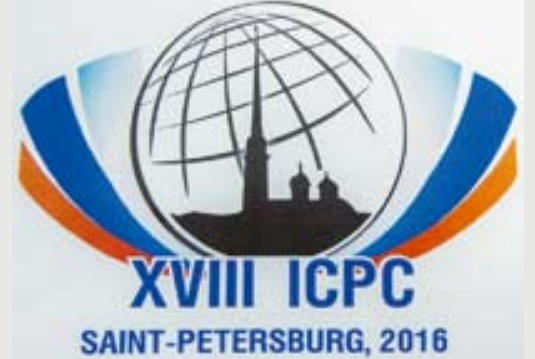

SAINT-PETERSBURG, 2016

\section{Первое заседание МОK}

\section{XVIII Международного конгресса по обогащению угля}

История Международных конгрессов по обогащению угля началась в середине прошлого века. Первый конгресс состоялся в 1950 г. в столице Франции. В соответствии спланом Маршалла, его целью было помочь европейской угольной промышленности встать на ноги после Второй мировой войны. С тех пор конгрессы, на которых обсуждаются наиболее острые вопросы развития отрасли, регулярно с периодичностью один раз в четыре года проходят в странах с развитой угольной промышленностью. За прошедшее время конгрессы проходили на всех пяти континентах.

В 1979 г. конгресс проходил в СССР, в чентре Донбасса Донецке. Россия принимает активное участие во всех форумах углеобогатителей, начиная с третьего конгресса. Российские специалисты выступают с интересными и содержательными докладами по наиболее актуальным проблемам в области обогащения угля. После пятого конгресса в состав Международного организационного комитета был введен постоянный представитель нашей страны.

Учитывая особую значимость и престижность данного международного мероприятия, роль России как одного из мировых лидеров в области горнодобывающей промышленности и углеобогащения, министром энергетики Российской Федерации Александром Новаком было принято решение лично возглавить национальный Оргкомитет по проведению XVIII Международного конгресса по обогащению угля. Министром подписан приказ о создании Национального организационного комитета XVIII Международного конгресса по обогащению угля, в состав которого включены руководители крупнейших угольных компаний, представители научных и проектных институтов, известные российские специалисты в области углеобогащения.

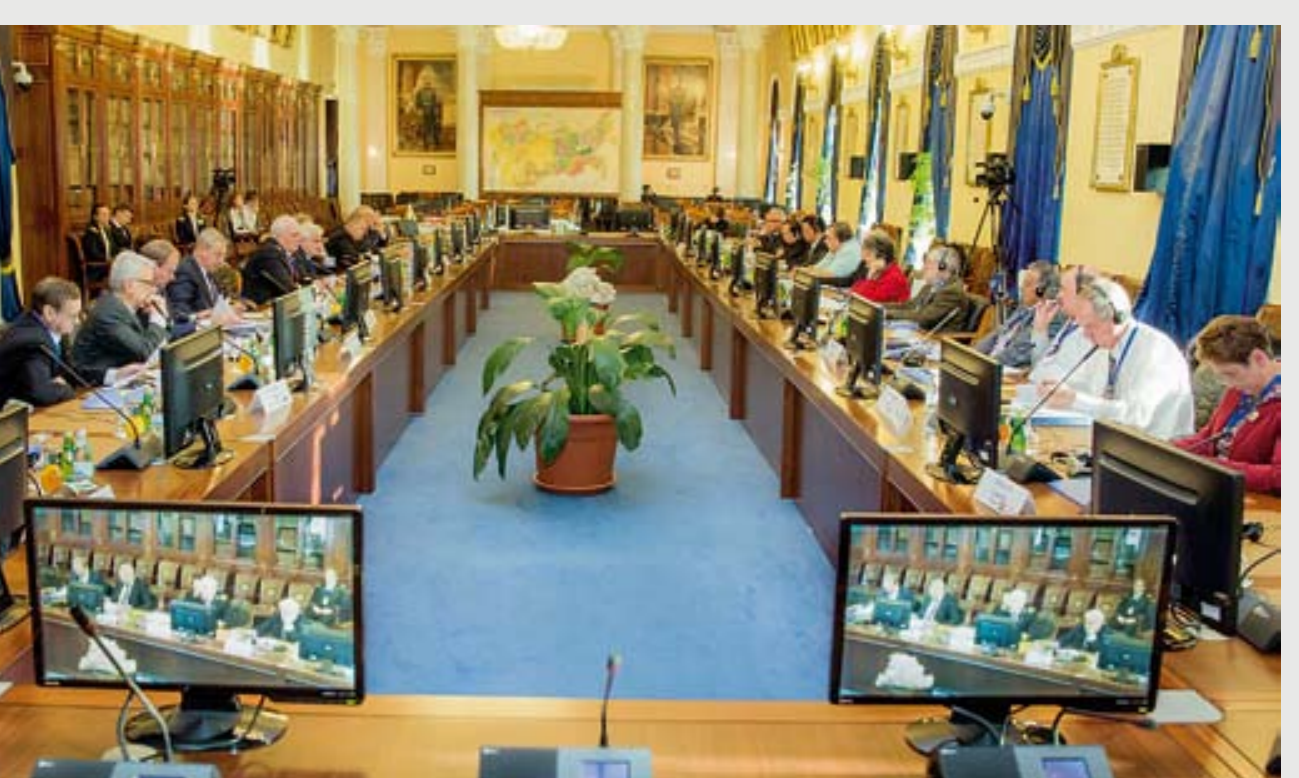

7 октября 2014 г. в Санкт-Петербурге на базе Горного университета прошло первое заседание Международного организационного комитета XVIII Международного конгресса по обогащению угля, который будет проходить здесь же с 28 июня по 1 июля 2016 г.

В торжественном открытии форума принял участие заместитель министра энергетики Российской Федерации Анатолий Яновский. «Убежден, что проведение XVIII Международного конгресса по обогащению угля в России пройдет на самом высоком организационном и профессиональном уровне, - отметил в своем приветственном слове Анатолий Яновский. - Хочу поблагодарить уважаемых членов Международного организационного комитета за принятое Вами решение о проведении XVIII Конгресса по обогащению угля в России и выразить уверенность, что нами будут приложены все усилия для проведения всехмероприятий столь авторитетного Форума на самом высоком организационном и профессиональном уровне!».

В течение трех дней делегаты десяти стран мира - Великобритании, Германии, Китая, США и других обсуждали технические вопросы подготовки к форуму, который состоится в 2016 г. В конгрессах, проводящихся раз в три года, принимают участие представители крупнейших профильных предприятий и научного сообщества ведущих угледобывающих государств. Одной из основных задач форума является обмен опытом внедрения на производстве технологий, позволяющих улучшить качество производимой продукции, выработка общей стратегии инновационного развития отрасли.

На первом заседании Международного организационного комитета (МОK) его члены - президенты национальных угольных ассоциаций, ведущие ученые своих стран рассмотрели предложения о новых темах секционных заседаний. Среди них - переработка отходов, возникающих в процессе обогащения угля, повышение экологических стандартов и некоторые другие.

На периоддо 2016 г. делегаты избрали председателем МOK научного руководителя НПК «Механобр-техника» Леонида Вайсберга, представляющего в оргкомитете Россию. Они также обсудили ряд технических вопросов, параметры выставки научных достижений, внедряемых в углеобогатительную отрасль, утвердили символику форума, определили страну — организатора Конгресса в 2019 г. Ею стала Индия.

Одной из задач, стоящих перед гостями вуза, было знакомство с инфраструктурой Горного университета. По их 
общему мнению, университет полностью готов к организации съезда, а его помещения соответствуют всем необходимым требованиям к проведению столь статусного мероприятия.

Представительница Турции, принимавшей предыдущий Конгресс по обогащению угля, Гюльхан Озбайоглу отметила: «Здесь есть все необходимое для организации Конгресса. В частности, многоканальные конферени-системы для синхронного перевода. Они одновременно обеспечивают перевод с русского сразу на несколько языков. Например, английский и китайский. Это очень важно. Вуз также располагает великолепными вместительными залами, которые могут принять такую значительную конференцию. Ну, и наконец, само здание - настоящий шедевр архитектуры, что, конечно же, пойдет на пользу имиджу нашего форума».

По поручению Президента России В.В. Путина, принята Долгосрочная программа развития угольной промышленности России на период до 2030 г. В этом документе описана перспектива развития каждого из угольных бассейнов, даны четкие прогнозные оценки.

Заместитель министра энергетики России Анатолий Яновский в своем выступлении сказал, что «основным драйвером роста добычи угля является постоянно увеличивающийся спрос на мировых рынках. В течение последних десяти лет у нас примерно одни и те же объемы поставок в западную Европу, Белоруссию, Украину, Турцию. А вот в Китае, Японии, Корее наблюдается устойчивый рост потребления. Это, безусловно, мотивирует отраслевые компании».

Также идет работа над созданием важнейшего для отечественной экономики документа — «Энергетической стратегии России».

Ректор Горного университета, профессор Владимир Литвиненко «уверен, что в ходе дискуссии о том, куда следует вкладывать инвестиции - в добычу или новые технологии, все-таки победит здравый смысл, и мы утвердим Стратегию, которая будет ориентирована на инвестиции именно в развитие технологий. Это позволит, например, получить при переработке угля новые жидкие компоненты, использовать его в качестве более эффективного и экологичного топлива». Он выразил надежду на то, что к 2016 г., когда в России будет проходить Международный конгресс по обогащению угля, российское правительство ощутит необходимость более активно заниматься этим направлением.

Для членов организационного комитета была предусмотрена и обширная культурная программа. Гости посетили Государственный Эрмитаж, Екатерининский дворец в Пушкине, посмотрели балет "Бахчисарайский фонтан" в Мариинском театре.
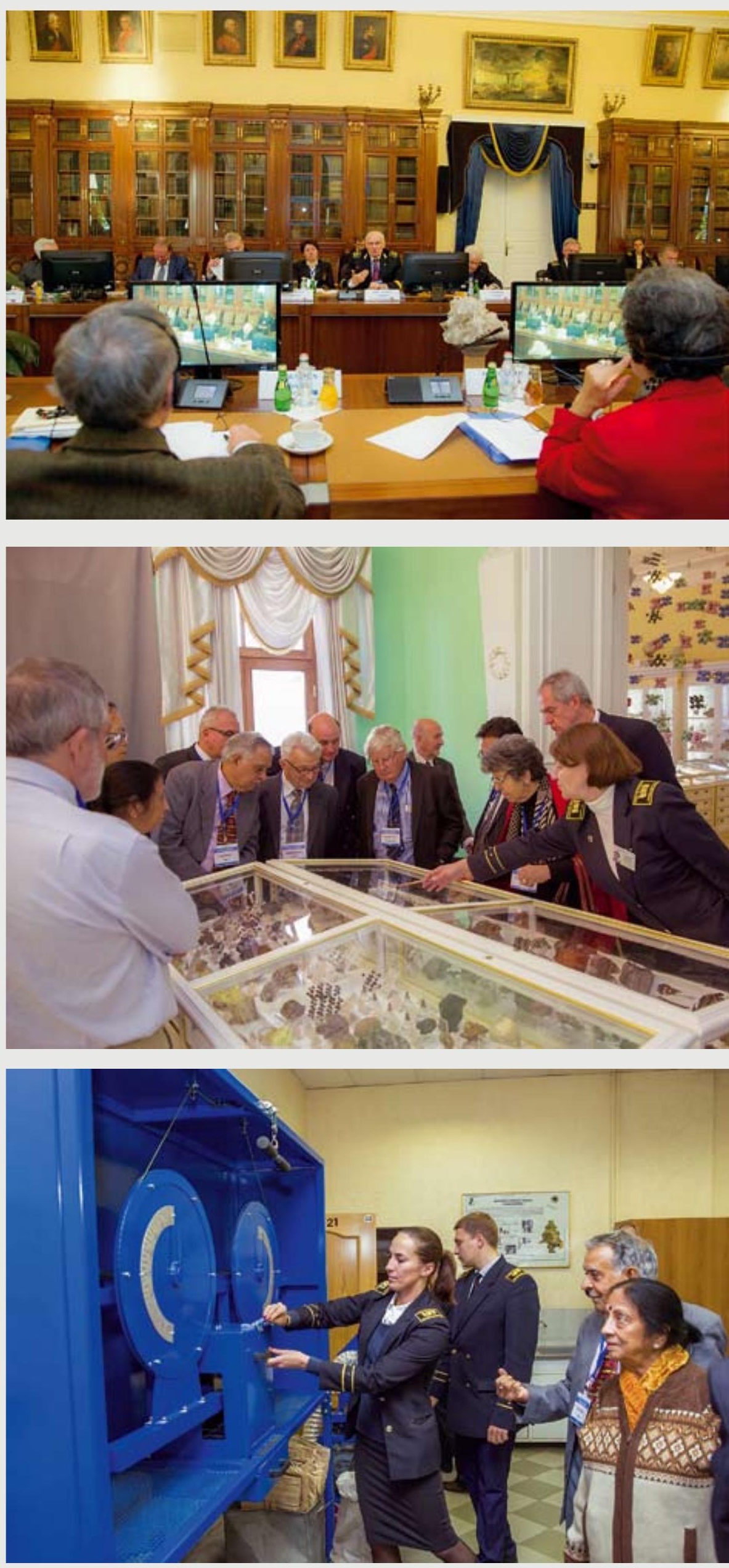

НОЯБРЬ, 2014, “УГОЛЬ” 


\section{Управление}

\section{углеобогатительными фабриками}

\section{современные решения на базе новых технологий}

В статье описываются существующие на российском рынке решения для автоматизации управления промышленными процессами, даются их краткие характеристики и статистика внедрений. Основной упор делается на отечественную pазработку - программу Coral Suite, созданную исключительно для применения на углеобогатительных предприятиях и не имеющую аналогов ни в России, ни за рубежом. Базирующаяся на новых технологиях и опыте разработчиков программа позволяет быстро и качественно решать задачи производственного характера, улучшая взаимодействие служб фабрики и обеспечивая более полный административный контроль.

Ключевые слова: системы автоматизачии прочессов на обогатительных фабриках, краткие характеристики, статистика внедрений, программа Coral Suite.

Непрерывный процесс ужесточения требований к качеству выпускаемой продукции заставляет углеперерабатывающие предприятия постоянно находиться в поиске новых технологических решений, позволяющих удовлетворять запросы рынка. Современные углеобогатительные предприятия уже немыслимы без автоматических систем контроля и управления, качество которых растет из года в год благодаря тесному сотрудничеству обогатителей и разработчиков программ автоматизации.

Особую роль в этом процессе играют программные решения, предназначенные для обеспечения работоспособности оборудования фабрик. Перечень проблем, которые могут быть решены с их помощью, довольно широк. Это и слабое информационное взаимодействие различных служб фабрики, мешающее планированию предупредительного ремонта. Длительное время на поиск технической документации по оборудованию, и недостаток информации для предварительного зака- за запчастей, мешающие своевременному формированию заявок на закупку ЗИП и расходных материалов. То есть те проблемы, которые либо сами являются причинами простоев, либо затрудняют поиск этих причин в силу своего скрытого от администрации фабрики характера.

Указанные проблемы, конечно же, присущи не только углеобогатительной отрасли. И это дает, с одной стороны, углеобогатителям возможность найти готовые решения в других производственных областях. Но, с другой стороны, специфика углеобогащения требует от разработчиков программ досконального знания процессов, иначе адаптированный продукт получится далеко не полным и будет неспособен окупить полностью ресурсы, затраченные на его установку.

На отечественном рынке сегодня присутствует достаточное количество игроков, предлагающих готовые решения для промышленных предприятий.

Из указанных на рис. 1 семнадцати решений отечественные компании представляют шесть продуктов: 1C: TOиP, Global-EAM, TRIM, Галактика; ИС: ТОиР Гроссмейстер, Парус. Из них в последние два-три года активно реализуются в проектах только четыре ТОиР, Global-EAM, TRIM, Галактика.

Эти системы универсальны и подходят практически для любой отрасли промышленности, однако ни одна из них не концентрирует своего внимания на конкретной отрасли.

Проекты внедрения систем ТОиР выполняются консалтинговым подразделением компании разработчика, интегратором либо самостоятельно заказчиком с привлечением консультаций от разработчика. Если проект внедряется разработчиком, то отрицательная сторона этого варианта заключается в том, что по своей сути разработчик - это программист, и в его компетенцию входит только автоматизация процессов, но не решение 


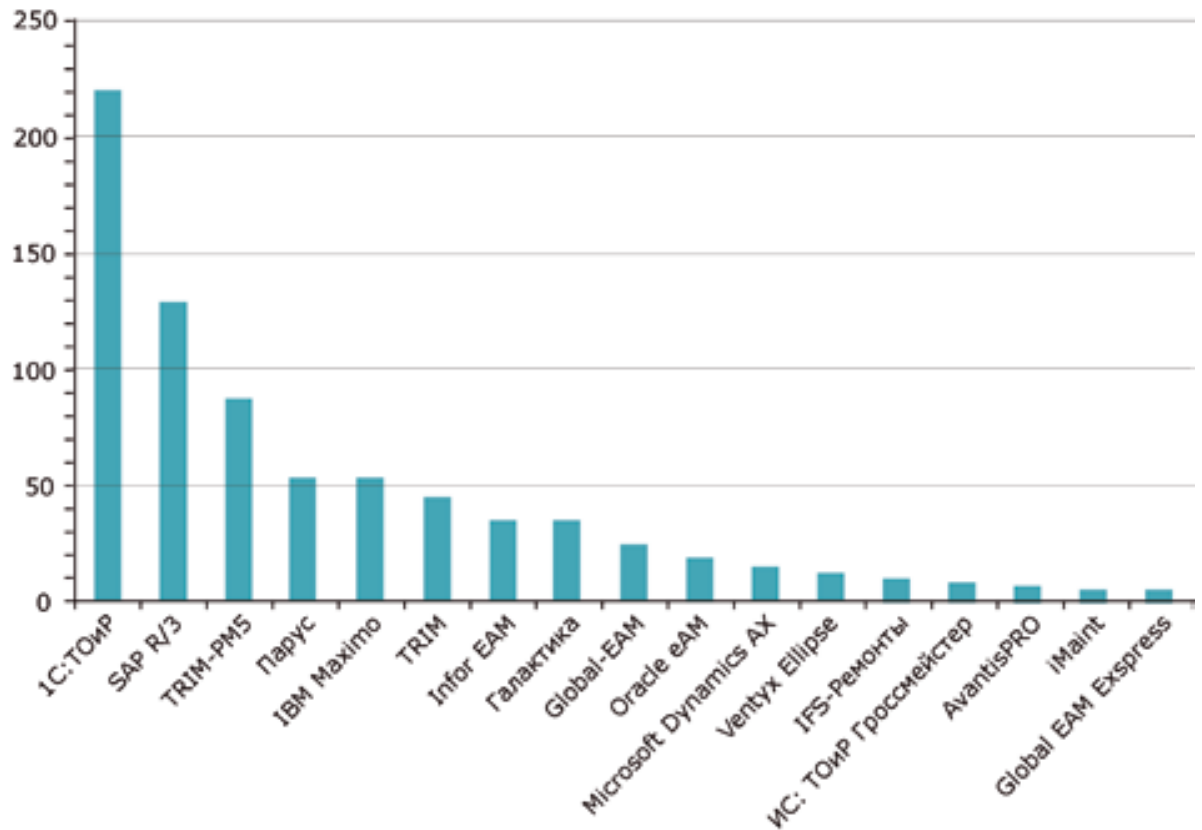

Puc. 1. Количество внедрений по продуктам на 2013 год [1]

задачи оптимизации управления ТОиР. Управленческого консалтинга в таких проектах почти не бывает, и эти функции берет на себя либо заказчик, либо приглашенный соисполнитель - консалтинговая компания.

Согласно данным из открытых источников [1] АСУ ТОиР имеет около 800 внедрений. На почти 25 объектах внедрения реализовывались второй и третий раз с разными продуктами, то есть одного (первого) внедрения было недостаточно. Рынок знает примеры, когда решение АСУ TОиР на базе одной и той же ERP внедряется повторно, что требует дополнительных затрат времени и денег.

\section{CORAL SUITE — РЕШЕНИЕ ДЛЯ УГЛЕОБОГАТИТЕЛЕЙ}

Департамент автоматизации компании «Коралайна Инжиниринг», опираясь на свой богатый опыт в создании систем автоматизации процессов на обогатительных фабриках, разработал и в текущем году уже приступил к внедрению первого в своем роде приложения, нацеленного на решение актуальных производственных задач углеобогатительных фабрик.

Программа диагностики и анализа работы оборудования - Coral Suite - позволяет каждому пользователю системы фабрики участвовать самому, а также видеть планы других работников фабрики по ремонту каждой единицы оборудования, пометки на чертежах и схемах, запланированные остановки секций фабрики. Программа предоставляет графики ППР и ремонтные карты на марки оборудования, обеспечивает доступ к базе данных документации по всему оборудованию, складу фабрики и складам запасных частей компании «Коралайна Инжиниринг».

На основе подробной и наглядной информации о простоях и причинах их возникновения программа предоставляет аналитические отчеты для выявления слабых мест как в работе фабрики, так и в работе каждой единицы оборудования.
Главное преимущество Coral Suite перед другими системами состоит в том, что она разрабатывалась ориентированной именно на углеобогатительные фабрики. В составе группы, работающей над продуктом, присутствуют как программисты, так и опытные специалисты, отвечающие за сбор информации с углеобогатительных фабрик и переработку этой информации в программные решения.

Другой уникальной особенностью Coral Suite является то, что в отличие от других подобных ей систем, программа изначально является web-приложением и может быть открыта на любом устройстве с интернет-обозревателем, например на персональном компьютере, планшете или мобильном телефоне. Именно по этой причине полноценно работать с приложением можно из любой точки мира при наличии доступа к Интернету.

Кроме того, приложение ориентировано как на управление с помощью мыши, так и на управление с сенсорного экрана и позволяет использовать многие возможности современных мобильных устройств - от фотографии дефекта механизма на камеру телефона до пометок на схемах и чертежах при помощи стилуса.

\section{ОПИСАНИЕ МОДУЛЕЙ СИСТЕМЫ}

Система представляет собой семь модулей - web-cтpaниц. Доступ к технической документации организован на основании трех модулей - «Паспорта», «Чертежи» и «Схемы» (рис. 2, 3, 4), каждый из которых имеет свой графический интерфейс и свою страницу в приложении.

Выбрав единицу оборудования фабрики, пользователь может просмотреть по ней чертежи, спецификации, электрические схемы и паспортные данные, переключаясь между модулями с помощью кнопок. На чертежах и электрических схемах можно оставлять пометки и сохранять их на отдельном слое.

При использовании мобильного устройства со встроенной камерой можно прямо из программы Coral Suite фотографировать чертеж или схему, которая тут же будет добавляться к выбранной единице оборудования.

Планами по развитию программы предусмотрен перевод чертежей в интерактивный вид, то есть по нажатию на пункт спецификации или на деталь оборудования можно сразу перейти на чертеж выбранной детали. В первую очередь в базу данных заносится информация о поставляемом «Коралайна Инжиниринг» оборудовании — марка оборудования, чертежи деталей, а также автоматически обновляемая информация о наличии запасных частей на складе компании и сроках его поставки.

Также есть возможность подключить базу данных оборудования склада углеобогатительной фабрики. В этом 


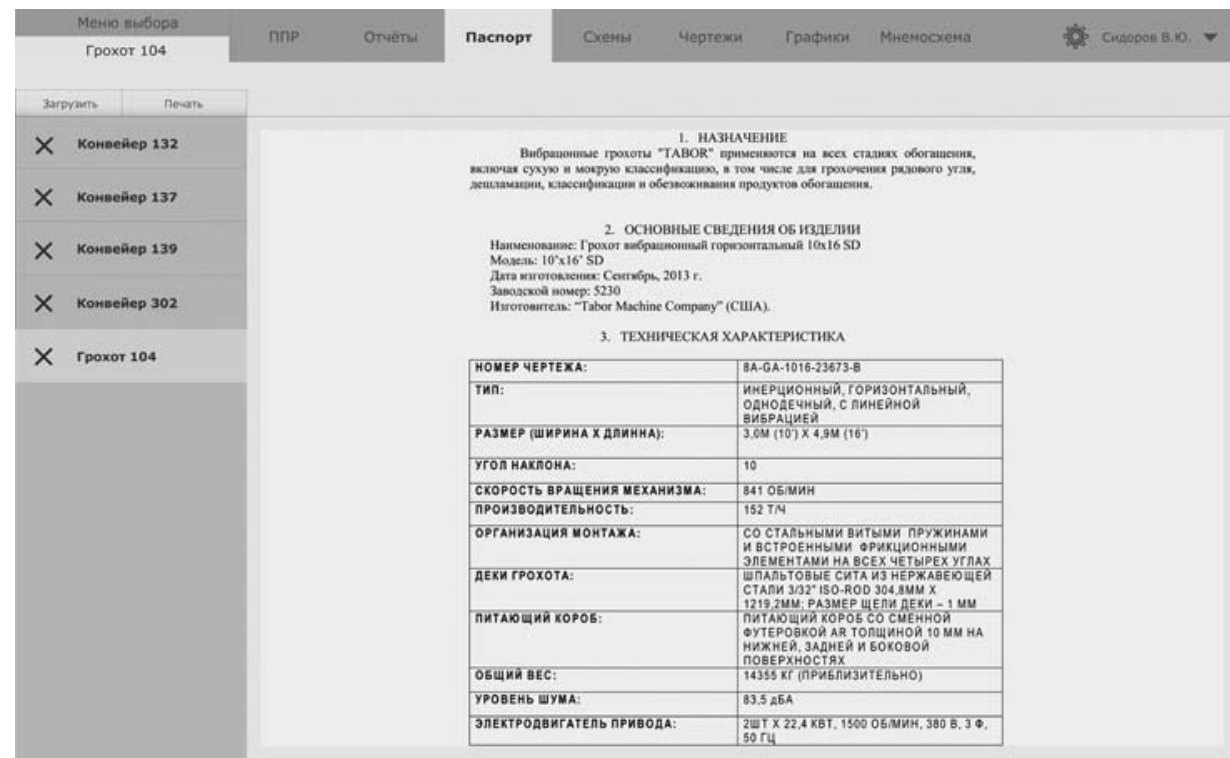

Puс. 2. Страница модуля "Паспорт"

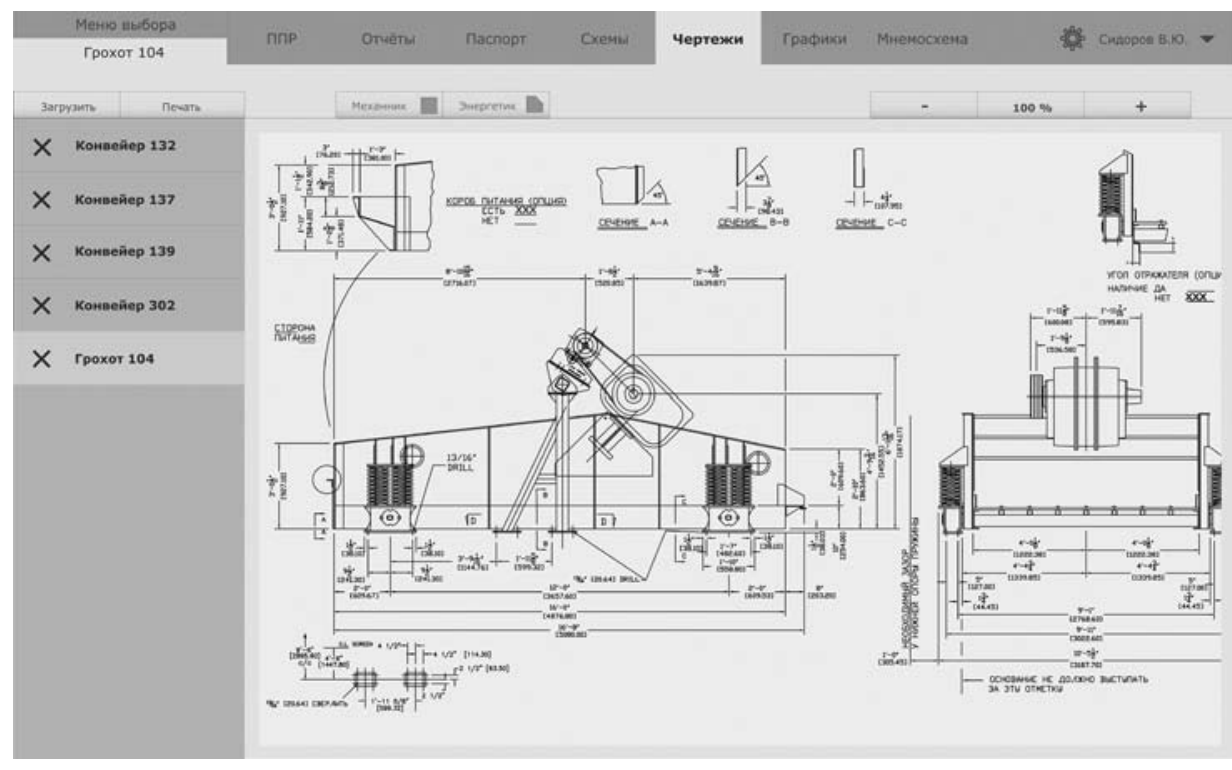

Рuс. 3. Страница модуля "Чертежи"

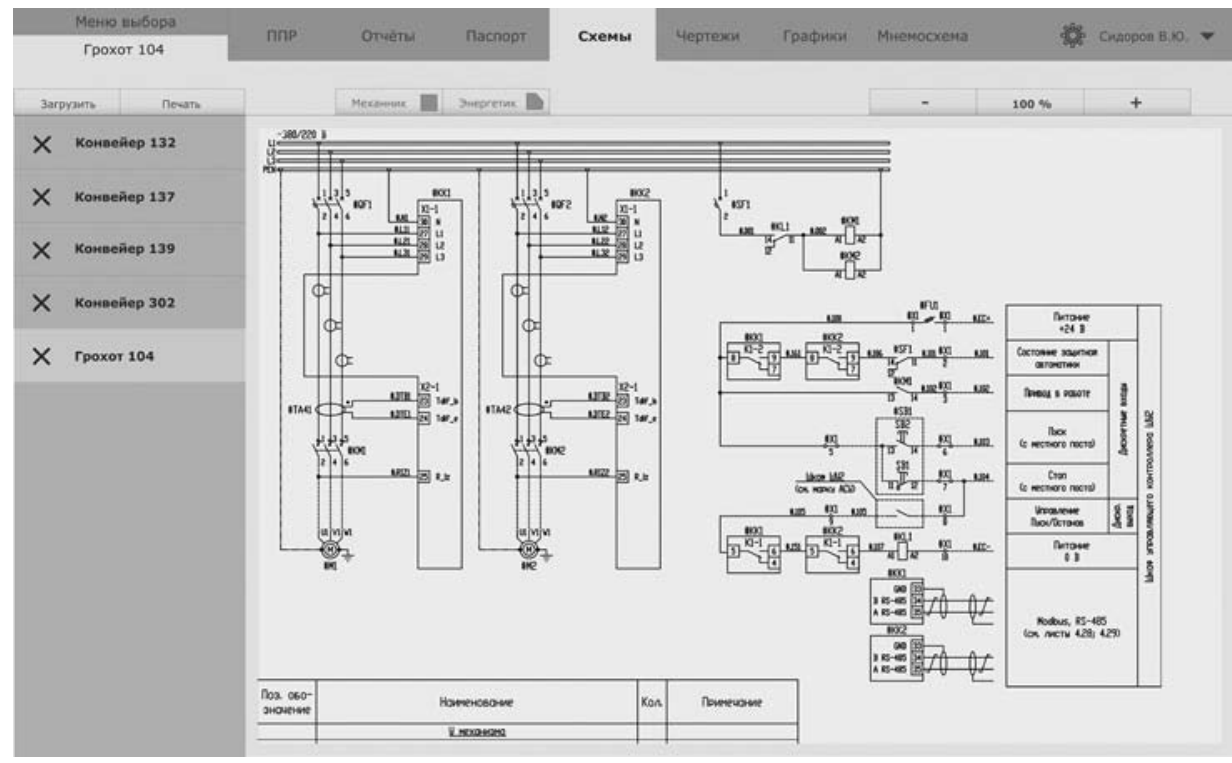

Puc. 4. Страница модуля "Схемы" случае дополнительно становится доступной информация о марке и наличии оборудования и запасных частей к нему на складе фабрики.

Доступ к данным по фабрике в целом обеспечивают четыре модуля - «Мнемосхема», «Отчеты», «Графики» и «ППР» - каждый из них расположен на своей webстранице с графическим интерфейсом.

На мнемосхеме (рис. 5) выводятся текущее состояние оборудования и основные технологические параметры фабрики, а также индикаторы времени между плановыми ремонтами.

В рамках программы мнемосхему можно, использовать как журнал передачи смен. Например, при нажатии на любую единицу оборудования можно создать текстовое сообщение, описывающее, что было сделано по оборудованию и что еще требуется сделать. После сохранения сообщения в Coral Suite оно будет привязано к той единице оборудования, с которой был открыт журнал. Сообщению будет присвоен порядковый номер, указаны дата создания сообщения и Ф.И.О. создавшего это сообщение. Персонал следующей смены, посмотрев на мнемосхему, увидит отметки на символах оборудования, для которого были созданы текстовые сообщения. Журнал можно пролистывать и распечатывать.

Модуль «Отчетная система» (рис. 6) предоставляет, по умолчанию, стандартный набор отчетов по оборудованию.

В него входят отчеты по авариям, наработке, простоям, сводным простоям, действиям оператора, дефектам и отчет по ремонтным работам. Для того чтобы создавать свои отчетные формы, в приложении Coral Suite предусмотрен конструктор отчетов, который очень прост в использовании и позволяет создавать отчеты любой сложности даже с планшета или телефона.

Модуль «Графики» (рuс. 7) предоставляет возможность про- 


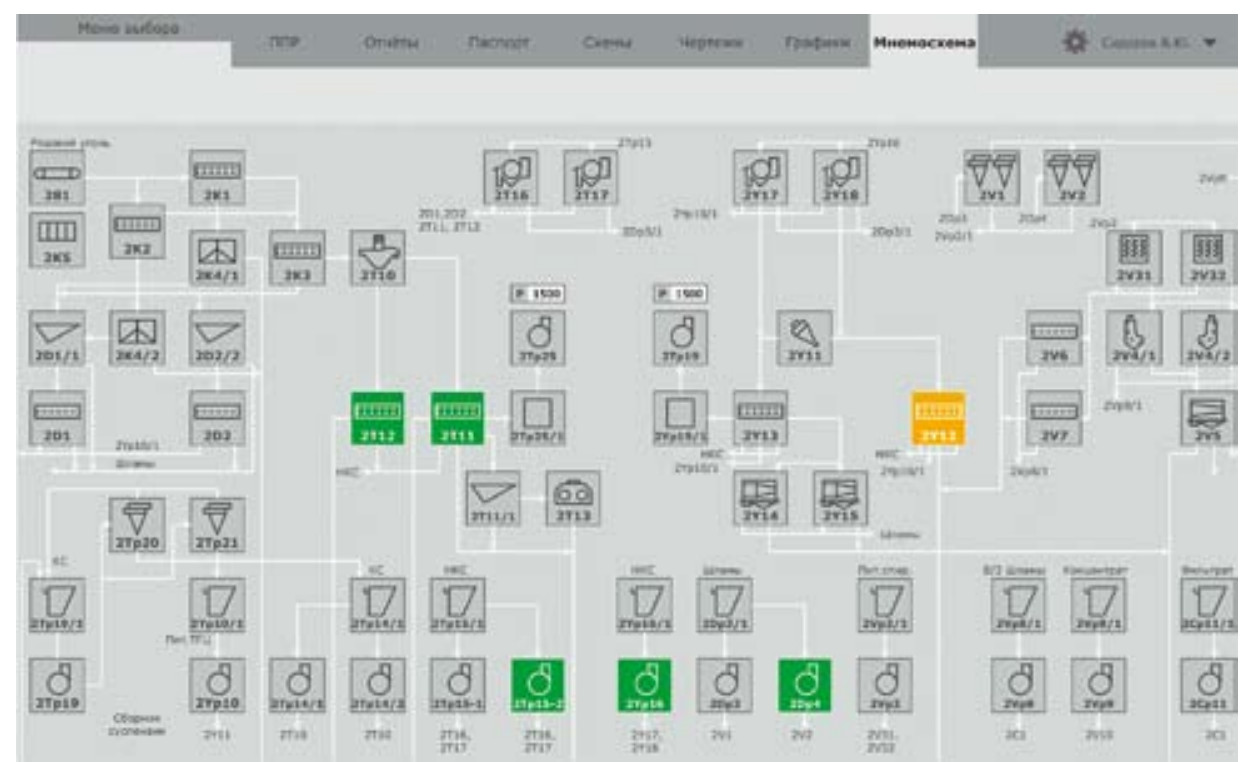

Puc. 5. Страница модуля "Мнемосхема"

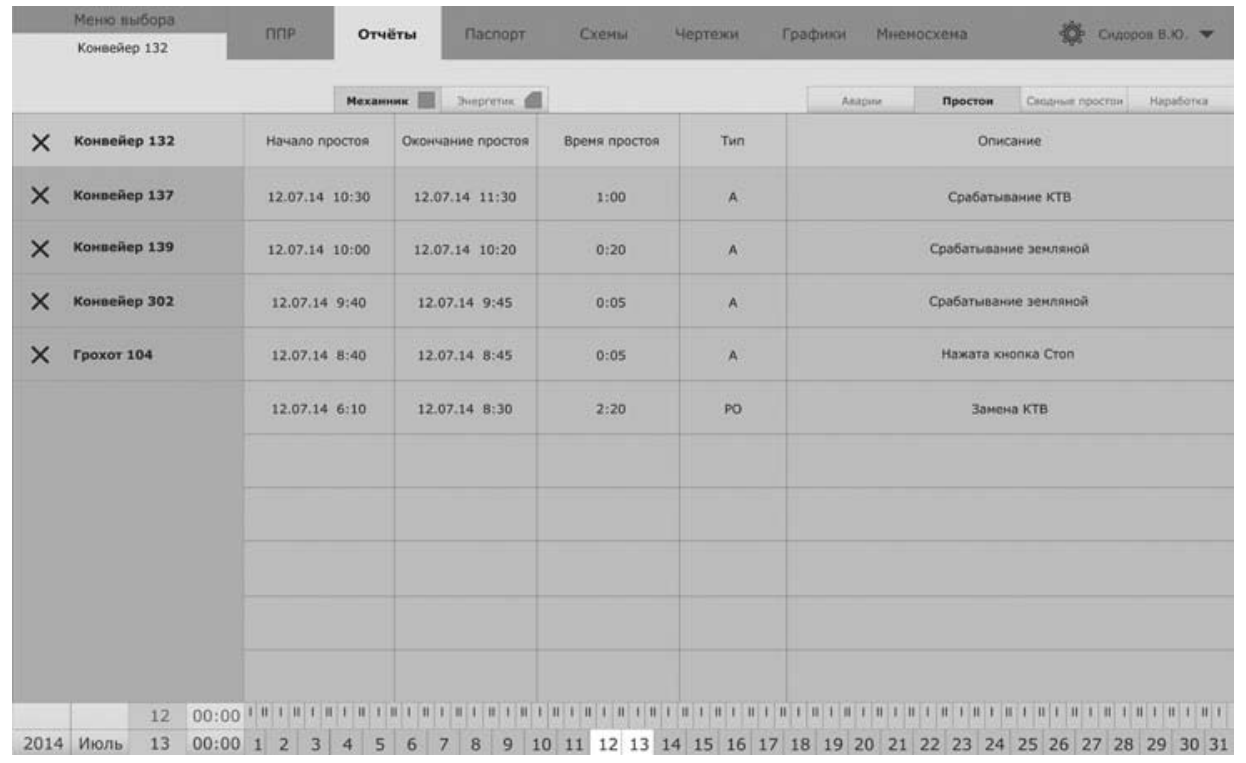

Puс. 6. Страница модуля "Отчетная система"

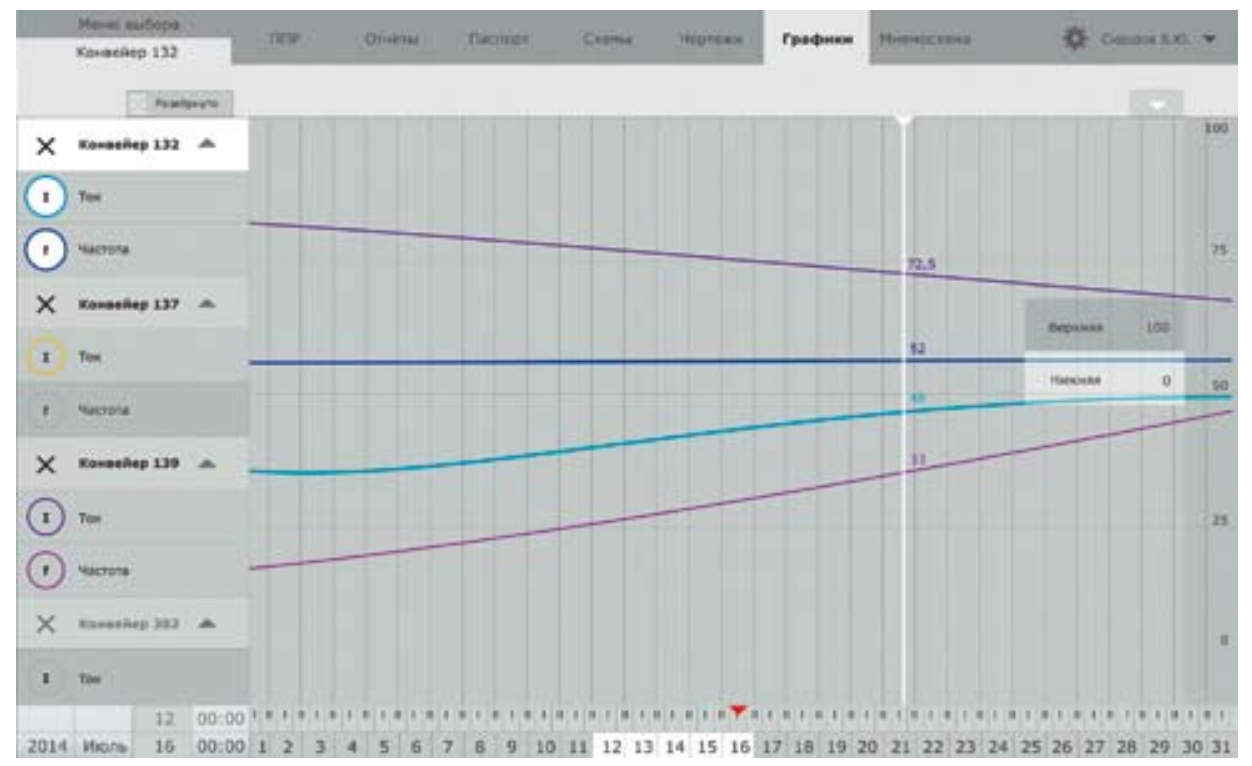

Puс. 7. Страница модуля "Графики" смотра аналоговых параметров оборудования по времени. Удобное включение и отключение отображения графиков на экране, установка шкалы, масштабирование по оси времени функции, создающие удобство пользователю.

Для нахождения соответствия между изменением параметра (например, плотности, влажности или зольности) и происходящими на фабрике событиями (например, авариями, простоями, действиями оператора и т.д.) реализуется функция совместного просмотра графиков аналоговых параметров и отчетов по оборудованию.

Работа с планом-графиком ППР представлена модулем (рис. 8), в котором плановые и фактические ремонты отображаются в виде диаграммы. Любой пользователь Coral Suite, в том случае если у него есть разрешение от системы, может составить для себя планграфик для интересующих его единиц оборудования, создав его на диаграмме модуля ППР либо загрузив в приложение файлы из Excel.

Каждый ремонт содержит в себе подробную информацию, в том числе ремонтную карту и ведомость дефектов. Фотографии дефектов могут быть сделаны с помощью мобильного устройства, на котором открыто приложение Coral Suite, либо загружены с отдельного компьютера.

Модуль ППР включает в себя планирование остановок секций фабрики с последующим их подтверждением. Запланированные остановки видят все пользователи системы, что помогает им корректировать и стыковать свои планы по обслуживанию оборудования.

\section{ЗАКЛЮЧЕНИЕ}

Применение передовых технологий в разработке и управлении программой Coral Suite в совокупности с узкой направ- 


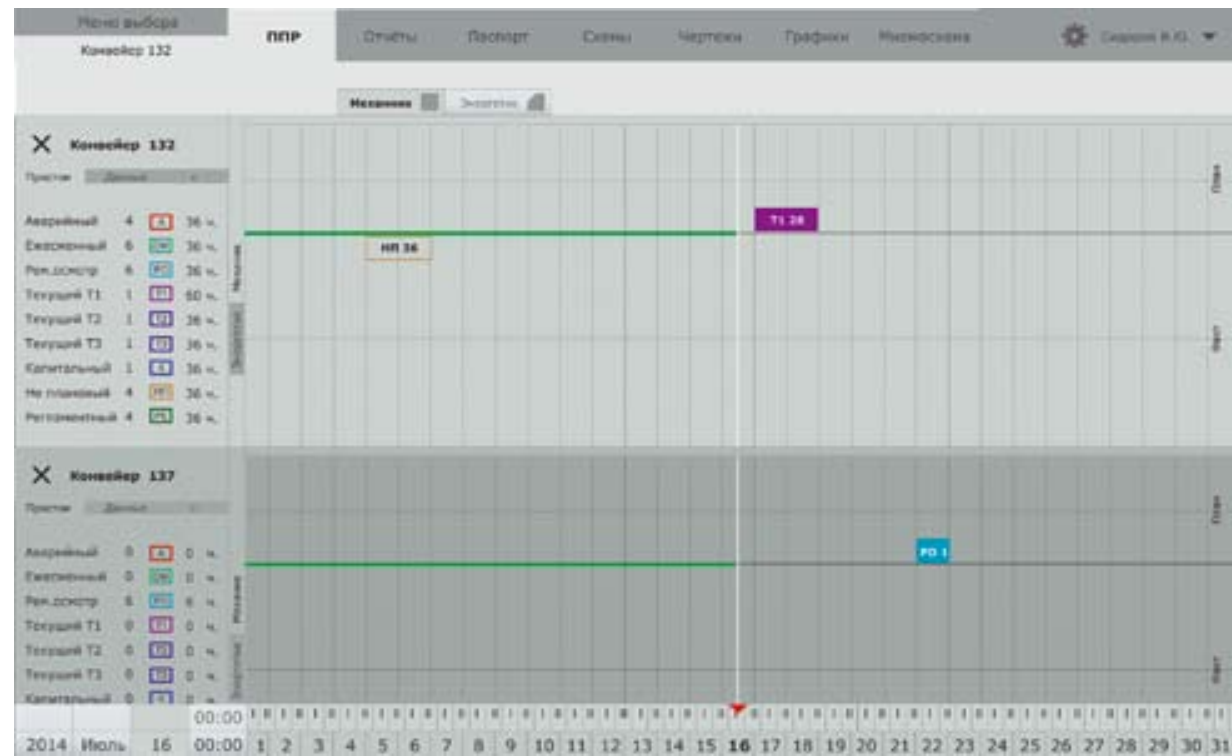

Рис. 8. Страница модуля «ППР»

ленностью на решение задач именно углеобогатительных фабрик делают новый продукт уникальным предложением на рынке, применение которого поможет углеперерабатывающим предприятиям увеличить свою конкурентоспособность, снизив простои и повысив качество взаимодействия служб внутри предприятий.

Основными достоинствами программы Coral Suite являются:

- быстрый и простой поиск причины простоя;

— легкий и быстрый доступ к документации по каждой единице оборудования фабрики;
- возможность обосновывать предварительный заказ запчастей планом-графиком ППР и аналитическими отчетами о причинах остановок как единицы оборудования, так и фабрики в целом;

- быстрый и удобный доступ к информации о наличии и сроках поставки запчастей;

- являясь web-приложением, программа может быть открыта на любом устройстве с интернетобозревателем;

- Coral Suite является коробочным продуктом, который может поставляться без данных по оборудованию.

Компания постоянно совершенствует свои программные продукты, нацеливая их на решение самых актуальных задач на углеобогатительных фабриках. Узнать подробно о программе Coral Suite и других услугах компании «Коралайна Инжиниринг» можно на сайте www.Coralina.ru

\section{Список литературы}

1. Данилов О., Скворцов Д., Свистула О. Автоматизация ТОиР. Хроника внедрений // и-Маш: Ресурс Машиностроения [Электронный ресурс]. URL: http://www.i-mash.ru/ materials/automation/ 35654-avtomatizacija-toir.-khronikavnedrenijj.html (дата обращения: 17.10.2014).

Title

\section{MANAGEMENT OF COAL PREPARATIONS PLANTS - MODERN SOLUTIONS BASED ON NEW TECHNOLOGIES}

\section{Authors}

Zadrutskiy D.V., Ter-Akopov A.G.

\section{Authors' Information}

Zadrutskiy D.V., software development group leader of "Koralayna Engineering" JSC, Moscow, Russia, e-mail: zadrutskiy@coralina.ru Ter-Akopov A.G., department director of electric power supply and automation of "Koralayna Engineering" JSC, Moscow, Russia

\section{Abstract}

The paper describes the existing solutions in the Russian market for industrial processes automation, their brief characteristics and implementation statistics are given as well. The main focus is aimed on domestic development, the Coral Suite program, created exclusively for use in coal preparation plants; this program has no analogues in Russia or abroad. It is based on the new technologies and developer's experience; this program allows the quick and effective solution of industrial problems, improving interaction of service departments providing a full administrative control.

\section{Keywords}

Process Automation Systems at the Coal-Preparation Plant, Brief Description, Implementations Statistics, the Coral Suite Program.

\section{References}

1. Danilov O., Skvortsov D., Svistula O. MRO Automation. Implementations chronicle. [Avtomatizatsiya MRO. Hronika vnedreniy] and-Mash, Materials Engineering [electronic resource]. URL: http://www.i-mash.ru/materials/automation/ 35654-avtomatizacija-toir.-khronika-vnedrenijj..html (date 17/10/2014). 


\section{Геодинамика кровли пласта 67} Талдинского месторождения

\section{при отработке его комплексом КГРП}

В статье рассмотрен практический опыт применения комплексов глубокой разработки угольных пластов в условиях Талдинского месторождения. В частности, представлен опыт управления горным давлением методом применения оптимальных технологических параметров, исследована динамика деструктивных процессов в кровле пласта при отработке его комплексом глубокой разработки пластов (КГРП).

Ключевые слова: комплекс КГРП, угольный пласт, кровля пласта, устойчивость кровли, межкамерные и межблоковые целики, безопасность.

Открытые горные работы на участке «Отвальный Южный №1» ООО «Разрез Южный» по восточному крылу пласта 67 Талдинского месторождения достигли своего предельного коэффициента вскрыши. В связи с чем было принято решение и подготовлена необходимая проектная и разрешительная документация для отработки остаточных запасов в лицензионных границах комплексом глубокой разработки пластов - КГРП (puc. 1).

Безопасность ведения горных работ комплексом КГРП во многом определяется устойчивостью обнажений кровли угольных пластов в горных выработках, то есть способностью кровли сохранять устойчивое состояние в незакрепленной зоне в течение необходимого периода времени в процессе отработки пласта. Устойчивость кровли определяется площадью обнажения и продолжительностью устойчивого состояния на незакрепленном участке. В соответствии с «Инструкцией...» [1] к неустойчивым непосредственным кровлям относятся кровли с пределом прочности пород на одноосное сжатие 20-40 МПа, а к весьма неустойчивым - менее 20 МПа. Параметры допустимых обнажений кровли для данных типов приведены в табл. 1.

Очевидно, что для приведенных параметров обнажений кровли для весьма неустойчивых пород кровель ведение

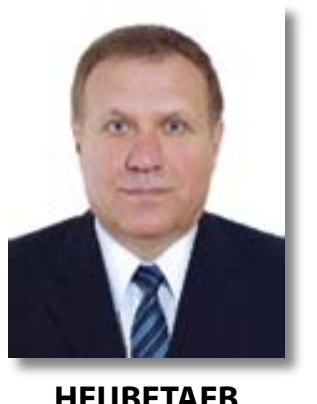

Александр Глебович

Доктор техн. наук, инициатор и руководитель проекта по добыче угля комплексом КГРП в России

2. Кемерово, Россия, e-mail:agn3000@mail.ru

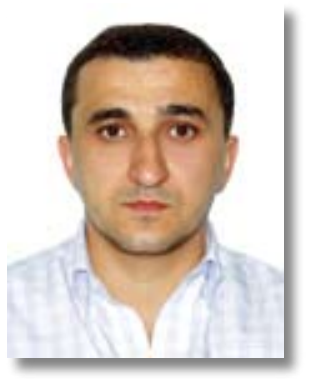

гРИГОРЯн

Армен Ашотович

Управляющий партнер

ООО «Иновационные горные технологии»

2. Кемерово, Россия, e-mail:armen008@mail.ru

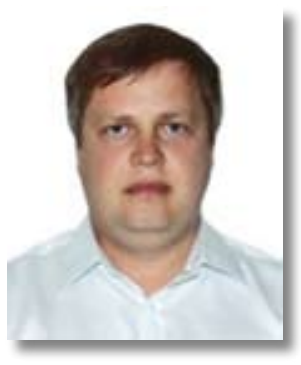

ПРУЖИНА

Денис Игоревич

Генеральный директор

ООО «Иновачионные

горные технологии»

2. Кемерово, Россия,

e-mail: denis088.kem@mail.ru очистных и подготовительных работ будет связано с опасностью обрушения пород в призабойное пространство выработок со всеми вытекающими негативными последствиями.

На основании статистики, накопленной при ведении горно-подготовительных работ на шахтах Кузнецкого бассейна, следует, что на стадии проходки примерно в 25-30\% из них происходят опасные деформации и потеря устойчивости породных обнажений, в том числе около $40 \%$ вне зоны влияния очистных работ и $60 \%$ - в зоне влияния очистных работ.

Потеря устойчивости породных обнажений приводит к снижению скорости проведения выработок на 40-45\% и увеличению расхода крепежныхматериалов. Кроме того, 35-40\% несчастных случаев при горно-подготовительных работах обусловлены потерей устойчивости породных обнажений и обрушением пород кровли и боков выработок.

Исследованиями ВНИМИ также установлено, что при прочности слоев пород кровли на одноосное сжатие 50-60 МПа и мощности их более 0,8 м породные обнажения сохраняют устойчивое состояние свыше двух часов, при мощности слоя 0,1-0,4 м и прочности пород при сжатии до 40 МПа время устойчивого состояния сохраняется в пределах одного часа, а при мощности слоев менее 0,1 м, что характерно для ложной кровли, время их устойчивого состояния составляет 10-20мин.

В сильнотрещиноватых породах, залегающих в основном над угольными пластами, с расстоянием между трещинами от 0,01 до 0,2 м, их устойчивость обычно не превышает 20 мин. Породы слабые, сильнотрещиноватые с расстоянием между трещинами 0,3-0,5 м, с пределом прочности на сжатие 20-40 МПа, устойчивы в течение 0,5-1,5 ч. Породы массивные, трещиноватые (0,6-1 м), прочностью 40-50 МПа устойчивы в течение 2-3,5 ч.

Устойчивая площадь и время устойчивости обнажения кровли для пласта 67 в соответствии с положениями ВНИМИ 

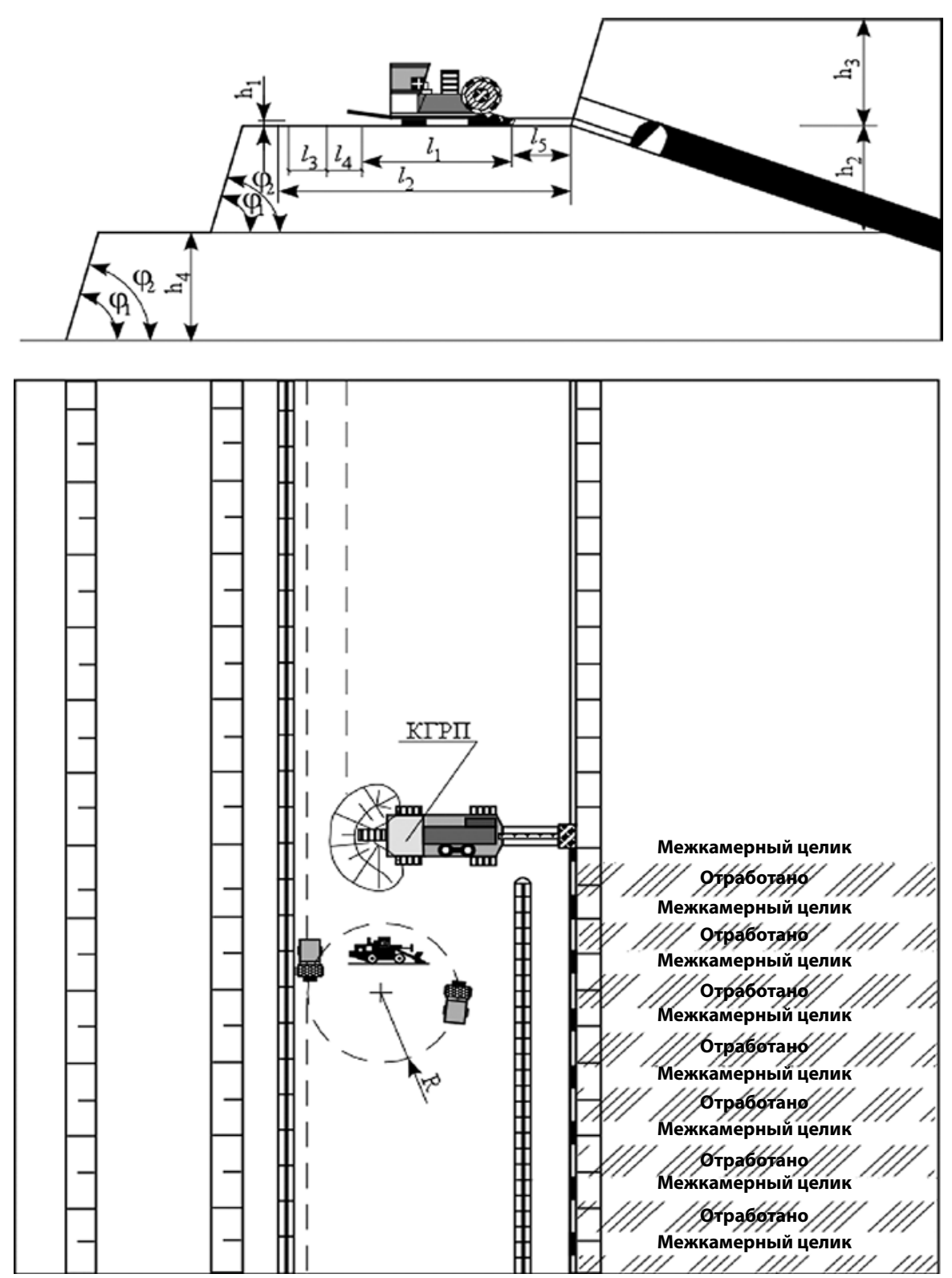

Рис. 1. Технологическая схема отработки пласта 67 комплексом КГРП были рекомендованы до 10 кв.м в течение 30 мин для неустойчивых кровель, 10-30 кв.м в течение 30120 мин - средней устойчивости и 30-60 кв. м в течение 120 мин и более для устойчивых кровель.

Визуальными наблюдениями, выполненными на шахтах Кузбасса разными исследователями, установлено, что устойчивая площадь обнажений на пластах с неустойчивой кровлей составляет 0-13 кв. м, при среднем значении 9,8 кв. м в течение 0-30 мин, при среднем значении 9,5 кв. м. На пластах с кровлей средней устойчивости 6,25-13,6 кв. м в течение 30 мин и более, при средних значениях соответственно 12,5 кв. М и Зомин.

В соответствии с вышеизложенным, для оценки устойчивости обнажений непосредственной кровли предложена типизация пород по устойчивости «Инструкцией...» [1], которая приведена в табл. 2. На практике для установления прочности пород при их обнажении значения прочности принимаются с учетом структурного их ослабления. Для коренных пород, не затронутых выветриванием, $\mathrm{K}_{\text {стр }}=0,9$.

В соответствии с характеристикой пород кровли (см. табл. 1) и с классификацией (см. табл. 2) непосредственные кровли свиты пластов в коренных невыветрелых породах относятся ко II классу, то есть к средней категории устойчивости, с допустимыми параметрами обнажения: 15-20 кв.м

таблица 1

Параметры устойчивости кровли

\begin{tabular}{|c|c|c|c|c|}
\hline \multirow{2}{*}{ Тип кровли } & \multirow{2}{*}{$\sigma_{\mathrm{cs}^{\prime}}, \mathrm{MПа}$} & \multirow{2}{*}{$\begin{array}{c}\text { Время устойчивого } \\
\text { состояния, мин }\end{array}$} & \multicolumn{2}{|c|}{ Допустимые размеры обнажения, м } \\
\hline & & & по простиранию & по падению \\
\hline Неустойчивая & $20-40$ & $10-50$ & До 0,5 & До 20,0 \\
\hline Весьма неустойчивая & до 20 & 10 & До 0,5 & До 0,5 \\
\hline
\end{tabular}

Таблица 2

\section{Типизация непосредственной кровли угольных пластов по устойчивости} в соответствии с «Инструкцией...» [1]

\begin{tabular}{|c|c|c|c|c|c|c|}
\hline $\begin{array}{c}\text { Класс и наименование } \\
\text { класса }\end{array}$ & $\begin{array}{c}\sigma_{\text {сж }}(\text { пород), } \\
\text { МПа }\end{array}$ & $\begin{array}{c}\text { Толщина слоя } \\
\text { пород, м }\end{array}$ & $\begin{array}{c}\text { Расстояние } \\
\text { между } \\
\text { трещинами, м }\end{array}$ & $\begin{array}{c}\sigma_{\mathrm{cж}} \\
\text { (угля), МПа }\end{array}$ & $\begin{array}{c}\text { Устойчивая } \\
\text { площадь } \\
\text { обнажения, м² }\end{array}$ & $\begin{array}{c}\text { Время устойчивого } \\
\text { обнажения кровли, } \\
\text { мин }\end{array}$ \\
\hline $\begin{array}{l}\text { I класс, } \\
\text { неустойчивая }\end{array}$ & До 30 & До 0,4 & До 0,4 & До 7 & До 10 & До 30 \\
\hline $\begin{array}{l}\text { II класс, } \\
\text { средней устойчивости }\end{array}$ & $30-60$ & $0,4-0,7$ & $0,4-0,7$ & Более 7 & $10-30$ & $30-120$ \\
\hline $\begin{array}{l}\text { III класс, } \\
\text { устойчивая }\end{array}$ & Более 60 & Более 0,7 & Более 0,7 & Более 9 & 30-60 и более & Более 120 \\
\hline
\end{tabular}


Расчетные размеры междукамерных, межблочных целиков угля и расстояния между межблочными целиками для свиты пластов проектного участка

\begin{tabular}{|c|c|c|c|c|c|c|c|}
\hline \multirow{3}{*}{ Пласт } & \multirow{3}{*}{$\begin{array}{l}\text { Мощность } \\
\text { пласта } \\
\text { (слоя), m, м }\end{array}$} & \multirow{3}{*}{$\begin{array}{c}\text { Угол падения } \\
\text { пласта, a, } \\
\text { градус }\end{array}$} & \multirow{3}{*}{$\begin{array}{c}\text { Сопротивление } \\
\text { угля сжатию, } \\
\sigma_{y}, \text { МПа }\end{array}$} & \multicolumn{4}{|c|}{ Размеры целиков } \\
\hline & & & & \multirow{2}{*}{$\begin{array}{l}\text { ширина меж- } \\
\text { дукамерного } \\
\text { целика, В мкц, м }\end{array}$} & \multirow{2}{*}{$\begin{array}{c}\text { ширина } \\
\text { межблочного } \\
\text { целика, В }\end{array}$} & \multicolumn{2}{|c|}{$\begin{array}{c}\text { Расстояние между блочными } \\
\text { целиками } \mathrm{L}_{\text {мби' }} \text { м }\end{array}$} \\
\hline & & & & & & no [2] & по [2] \\
\hline 68 & 5,0 & 10 & 11,3 & 3,4 & 7,2 & 45 & 72 \\
\hline 67 & 4,2 & 10 & 11,3 & 3,0 & 6,6 & 45 & 64 \\
\hline 66 & 3,0 & 10 & 11,3 & 2,8 & 4,8 & 45 & 52 \\
\hline
\end{tabular}

Таблица 4

Рекомендуемые параметры системы КГРП для отработки запасов пластов 66, 67 и 68 на участке «Отвальный Южный №1» ООО «Разрез Южный» $[2,3]$

\begin{tabular}{|c|c|c|c|}
\hline \multirow{2}{*}{ Наименование параметров } & \multicolumn{3}{|c|}{ Показатели параметров для пластов } \\
\hline & 66 & 67 & 68 \\
\hline Мощность пласта, м & 3,0 & 4,2 & 5,0 \\
\hline Ширина выемочных камер, м & 3,5 & 3,5 & 3,5 \\
\hline Ширина междукамерных целиков, м & 1,4 & 1,8 & 2,4 \\
\hline Ширина межблочного целика, м & 2,8 & 3,6 & 4,8 \\
\hline Расстояние между межблочными целиками, м & 60 & 55 & 45 \\
\hline Расчетные проектные потери угля при отработке запасов, \% & \multicolumn{3}{|c|}{$46-47$} \\
\hline
\end{tabular}

по площади обнажения в течении 60-70мин. В зоне выветривания непосредственные кровли пластов относятся к I классу, то есть к категории неустойчивых, с допустимой площадью обнажения 7-9 кв.м в течении 20-25 мин.

С учетом установленных классов устойчивости непосредственной кровли пластов на проектном участке «Отвальный Южный №1» активная их кровля отнесена в соответствии с единой классификацией кровли пологих пластов [2] к следующим классам:

2.2.2 - среднеуправляемая, вне зоны выветривания пород;

3.3.2 - трудноуправляемая, в зоне выветривания пород.

Классы кровли приняты едиными для свиты пластов, без их разделения с учетом залегания в кровле и почве в основном одних и тех же типов пород (алевролитов и песчаников).

В соответствии с действующими методическими положениями [2] по расчету размеров междукамерных и межблочных целиков угля, а также расстояния между межблочными целиками для системы КГРП определены расчетные оптимальные значения данных параметров, которые представлены в табл. 3.

Учитывая установленные закономерности проявлений горного давления и специфику технологии ведения горных работ при системе КГРП, обоснованы оптимальные технологические параметры, обеспечивающие условия применения системы с коэффициентом извлечения запасов на проектном участке, равным 0,53-0,54, рекомендуемые значения которых приведены в табл. 4.

В соответствии с проектом на отработку пластов 66, 67, 68 комплексом КГРП к первоочередной выемке были приняты запасы пласта 67, так как в процессе открытых горных работ уже была подготовлена рабочая площадка для работы КГРП. Протяженность 1 блока по пласту 67 составила 137м с учетом ширины выработок в 3,5 м, ширины межкамерных целиков в 1,8 м и межблочных целиков в
3,6 м, количество отработанных камер составило 24шт. Фактическая длина их по падению пласта изменялась В диапазоне 45-161 м, составляя в среднем 118 м. Ширина оставляемых междукамерных целиков изменялась от 1,75 до 2,4 м, а межблочных составила 3,5 и 3,3 м. Фактические технологические параметры системы КГРП при отработке пл. 67 в основном соответствуют их проектным и расчетным значениям.

Однако в апреле 2014 г. в процессе отработки КГРП добычного блока по пласту 67 на участке происходило оседание пород кровли с разрушением угольных целиков по всему фронту отработанных камер, в том числе и находящихся в непосредственной отработке (рис. 2).

За период, прошедший с начала проседания массива и ступенчатых проседаний крровли пласта 67, проседа-

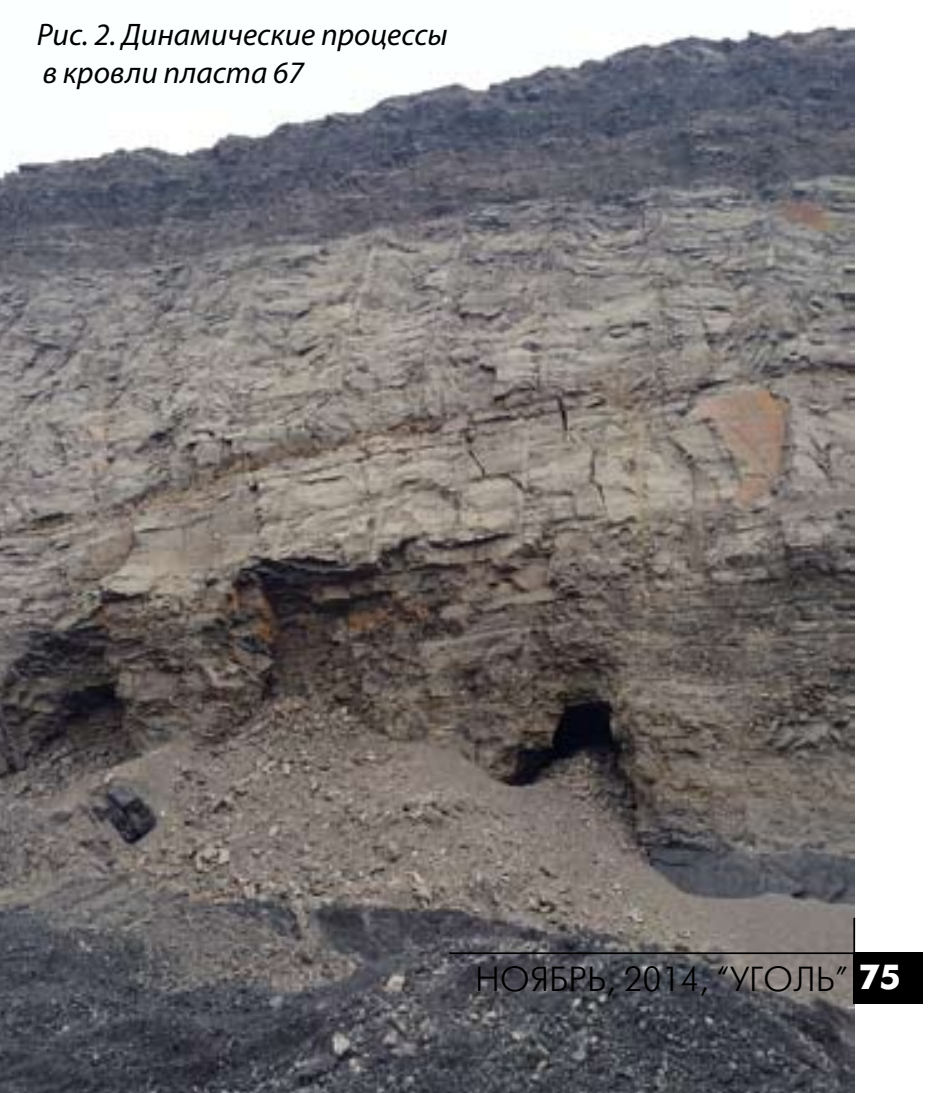




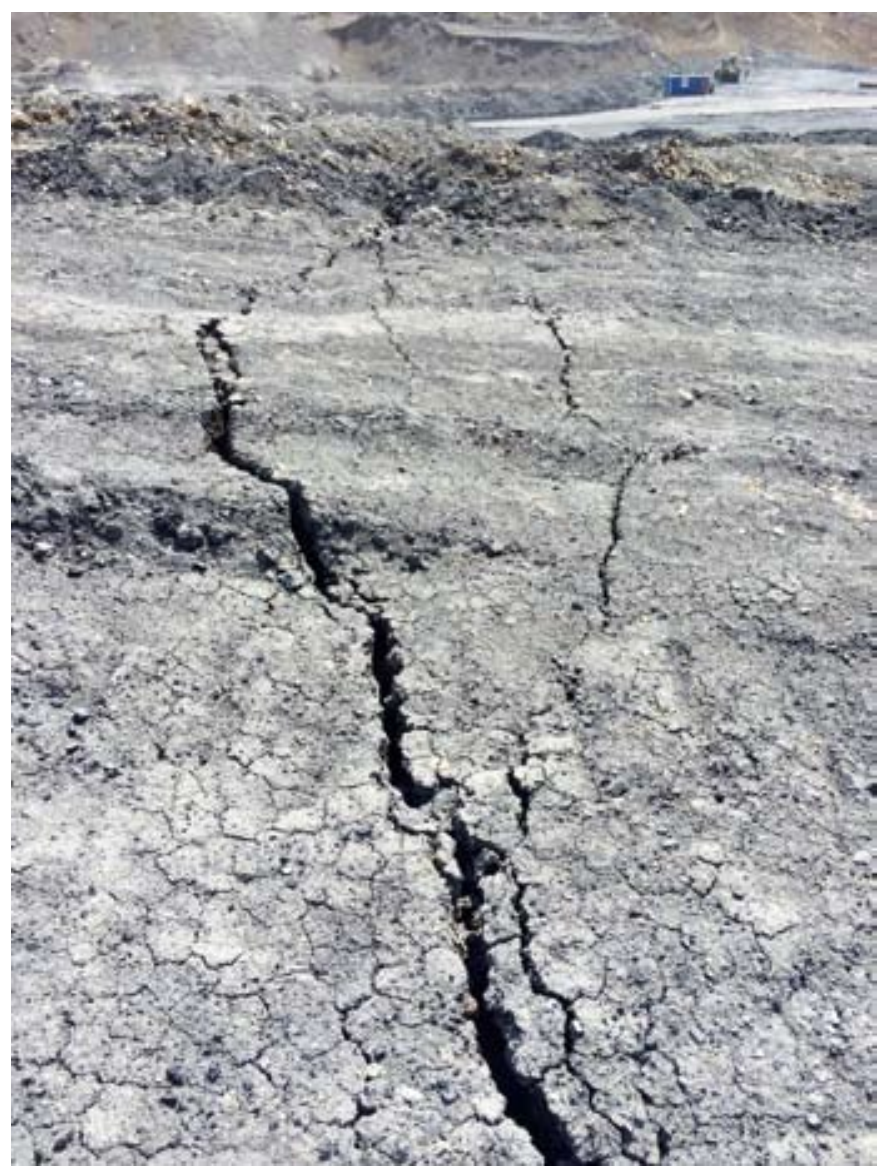

Рис. 3. Образование трещин, выходящих на вышележащий горизонт

ний почвы вышележащего пласта 68 выявлено не было. Проседание почвы имеет форму синклинали с максимальной величиной проседания по оси, равной 0,5 м, длина синклинали составила порядка 200-230 м. Мощность междупластья между пластами 67 и 68 составляет 35 м, развитие процесса проседания массива сопровождалось раздавливанием межкамерных целиков и образованием поперечных и продольных трещин, выходящих на вышележащий горизонт (рис. 3).

\section{Рис. 4. Отработка барьерного межблокового целика $45 \mathrm{M}$}

За время отработки запасов на участке «Отвальный Южный №1» ООО «Разрез Южный» развитие процесса оседания было зафиксировано два раза. В обоих случаях оседание происходило после отработки 24 камер, что соответствует фронту ведения работ длиною в 130-140 м. Развитие процесса оседания массива можно разбить на несколько временных промежутков:

- начальный период развития проседания массива имеет кратковременное развитие, сопровождающееся быстрым проседанием вышележащего горизонта на 0,2 м;

- вторым этапом происходит просадка мульд обрушения над камерами высотою до 24 м. Данный этап развивался в течение 2 мес.;

- третий этап происходил в сочетании со вторым этапом сопровождался оседанием и образованием трещин в почве вышележащего пласта 68. Процесс проседания и трещинообразования развивался в течение 3 мес.

Дальнейшее ведение очистных работ на контакте с отработанным участком пласта стало небезопасным, так как породы кровли в отработанном блоке находятся в неустойчивом состоянии и подвержены динамическим процессам, таким как оседание, образование, образование трещин и вывалов, что создавало угрозу безопасности работ и могло привести к различным аварийным ситуациям. В соответствии со сложившейся геодинамической ситуацией совместно с ВНИМИ [4] было принято решение между отработанным фронтом и приготовленным к отработке оставить межблоковый целик в 45 м при проектной ширине в 3,6 м и продолжить отработку пласта 67 комплексом КГРП на безопасном расстоянии от границы отработанного участка, подвергшегося динамическим процессам.

Ширина данного барьерного целика принята из расчета равенства установленному оптимальному расстоянию между блочными целиками, то есть площади одного выемочного блока. Дальнейшая отработка пласта 67 происходила в соответствии с проектными параметрами и в штатном режиме. Устойчивость кровли пласта 67 соответствовала расчетным параметрам.

В процессе наблюдения за динамикой пород кровли пласта 67 в оставленном межблоковом целике шириной в 45 м и соседнем отработанном блоке, в котором развились динамические процессы в кровли пласта 67, было установлено, что устойчивость пород кровли стабилизировалась и динамические процессы в виде оседаний, образования поперечных и продольных трещин в массиве кровли пласта полностью прекратились.

После завершения отработки оставшейся за барерным целиком части пласта 67 по всему фронту практически через три месяца КГРП был возвращен на оставленный увеличенный межблоковый целик, который отработкой был сокрашен до $8 \mathrm{M}$ без потери устойчивости кровли пласта 67 (рис. 4). 
В процессе отработки пласта 67 с применением КГРПустановлено, что к основным мерам по обеспечению безопасности необходимо:

- применять гибкий выбор технологических параметров для данной системы разработки и рациональный способ управления горным давлением;

- проводить необходимые инструментальные наблюдения за состоянием горного массива над выемочными камерами;

- на основании инструментального контроля и полученной статистики составлять постоянный оперативный прогноз состояния массива.

\section{Список литературы}

1. Инструкция по геологическим работам на угольных месторождениях Российской Федерации. СПб, 1993. 147 с.

2. Временные указания по управлению горным давлением в очистных забоях на пластах мощностью до 3,5 м с углом падения до $35^{\circ}$. Л.: ВНИМИ, 1982.

3. Первый российский опыт применения технологии глубокой разработки угольных пластов: устойчивость массива и потери угля в недрах / А. Г. Нецветаев, Л.Н. Репин, А. В. Соколовский, А.В. Юткин // Уголь. 2004. № 12. С. 10.

4. Заключение ВНИМИ «О возможности безопасной отработки пластов 66, 67 и 68 комплексом глубокой их разработки (КГРП) с выбором оптимальных технологических параметров и обоснования возможности выемки запасов в условиях ООО «Разрез Южный» на участке «Отвальный Южный №1». СПб.: ВНИМИ, 2013.
UDC 622.271:622.273.3:622.33.012.3 @ A.G. Netsvetaev,

A.A. Grigoryan, D.I. Prugina, $2014 \quad$ ISSN 0041-5790 • UGOL No11-2014/1064/

Title

GEODYNAMICS OF THE COAL SEAM ROOF 67 AT THE TALDINSKY DEPOSIT THROUGH THE USE OF THE HIGHWALL MINING COMPLEX

\section{Authors}

Netsvetaev A.G., Grigoryan A.A., Prugina D.I.

\section{Authors' Information}

Netsvetaev A.G., Doctor of Technical Sciences Initiator and the leader of the Highwall coal mining project in Russia, Kemerovo, Russian Federation, e-mail: agn3000@mail.ru

Grigoryan A.A., Partner LLC "Innovative mining technology", Kemerovo, Russian Federation, e-mail: armen008@mail.ru

Prugina D.I., General Director LLC "Innovative mining technology", Kemerovo, Russian Federation, e-mail: denis088.kem@mail.ru

\section{Abstract}

This article describes the practical application of a deep coal seam Highwall mining complex at the Taldinsky coal deposit. In particular, it provides a study of the method of rock pressure control while applying the optimal process parameters and the dynamics of destructive processes in the formation of the seam roof while using the Highwall mining complex.

\section{Keywords}

Complex KGRP, Coal seam, Roof formation, Stability of the seam roof, Interblock and interchamber pillars, Safety.

\section{References}

1. Instructions for geological works in the coal fields of the Russian Federation. [Instruktsiya po geologicheskim rabotam na ugolnyh mestorozhdeniyah Rossiyskoy Federatsii] St. Petersburg, 1993, $147 \mathrm{p}$.

2. Temporary instructions on mining pressure management in mining faces in layers of up to $3.5 \mathrm{~m}$ with the slope angle of $35^{\circ}$. [Vremennye ukazaniya po upravleniyu gornym davleniem $v$ ochistnyh zaboyah na plastinah moshchnostyu do 3,5 $\mathrm{m}$ s uglom padeniya do $35^{\circ}$ ] Leningrad, VNIMI - ARRIDI, 1982.

3. Netsvetaev A.G., Repin L.N., Sokolov A.V., and Yutkin A.V. Russia's first experience with the technology of coal seams deep mining: the solid stability and coal loss of in the mines. [Pervyy rossiyskiy opyt primeneniya tehnologii glubokoy razrabotki ugolnyh plastov: ustoychivost massiva I poteri uglia v nedrah] Ugol-Coal, 2004, №12, C.10.

4. ARRIDI Conclusion "On the possibility of safe mining of 66 th, 67 th and 68 th seams by the deep extraction of seam complex (DESC) choosing the optimal technological parameters and justification of possibility of reserves extraction in terms of "Razrez Juzhniy" on the "Otvalnyi Yuzhnyi №1" section. [Zaklyuchenie VNIMI “O vozmozhnosti bezopasnoy otrabotki plastov 66, 67 i 68 kompleksom glubokoy ih razrabotki (KGRP) s vyborom optimalnyh tehnologicheskih parametrov I obosnovaniyu vozmozhnosti vyemki zapasov v usloviyah OOO"Razrez Juzhniy" na uchastke "Otvalnyi Yuzhnyi №1"] St. Petersburg, VNIMI — ARRIDI, 2013.

\section{Бородинский разрез обновляет автопарк}

Автотракторный цех Бородинского угольного разреза пополнился новой техникой: транспортники получили автогрейдер TG-250, созданный российским предприятием при участии американских разработчиков. Машина предназначена для обслуживания и ремонта дорог, профилировочных и землеройных работ.

Новый автогрейдер более функциональный, чем работавший на предприятии предшественник, компактный, удобный в управлении. Разработчики автогрейдера TG-250 позаботились и о комфорте водителя: кабина имеет принципиально новую конструкцию, позволяющую машинисту работать и стоя, и сидя. Кроме того, она оснащена современными системами кондиционирования и обогрева:даже зимой в кабине можно находиться без верхней одежды.

Новый дизайн копотной системы обеспечивает свободный доступ кузлам и агрегатам машины. Автогрейдер TG-250 оснащен мощным двигателем, автоматической коробкой передач. В соответствии с современными требованиями безопасности на автогрейдер установлена аварийная противопожарная система.

В следующем году транспортники ожидают поставку еще одного такого же автогрейдера. Только за последние два года благодаря реализации на предприятиях СУЭК масштабной инвестиционной программы парк АТЦ Бородинского разреза пополнился тридцатью единицами новой специальной техники.
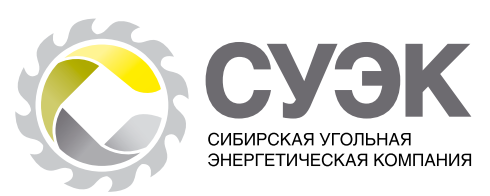

Наша справка

ОАО «Сибирская угольная энергетическая компания» (СУЭК) - крупнейшее в России угольноеобъединение по объему добычи. Компания обеспечивает около $30 \%$ поставок угля на внутреннем рынке и примерно 25\% российского экспорта энергетического угля. Филиалы и дочерние предприятия СУЭК расположены в Забайкальском, Красноярском, Приморском и Хабаровском краях, Кемеровской области, в Бурятии и Хакасии и Мурманской области. 


\section{Экологические последствия разрушения рельефа углепородных отвалов под влиянием природных факторов}

\author{
ЗЕНЬКОВ Игорь Владимирович \\ Доктор техн. наук \\ Специальное конструкторско-технологическое \\ бюро «Наука» КНЦ СО РАН, \\ nрофессор ФГАОУ ВПО \\ «Сибирский федеральный университет» \\ 2. Красноярск, Россия, \\ e-mail:zenkoviv@mail.ru
}

\author{
ЩАДОВ Иван Михайлович \\ Доктор техн. наук, \\ профессор ФГБОУ ВПО «Иркутский \\ государственный технический университет» \\ 2. Иркутск, Россия
}

\section{НЕФЕДОВ Борис Николаевич}

Канд. техн. наук

Специальное конструкторско-технологическое

бюро «Наука» КНЦ СО РАН, г. Бердск, Россия

На территории угледобывающих регионов Сибири, начиная с 1950-хгг., масштабно отсыпаются углепородные отвалы при добыче угля открытым способом. В ходе многолетних полевых экспедиций установлено, что породные отвалы разрушаются под влиянием водной эрозии, что приводит к образованию многочисленных оврагов. На этапе отсыпки вскрышных пород в тело отвалов укладываются углесодержащие породы, которые при их выносе водными потоками начинают самовозгораться при контакте с атмосферным воздухом. Выявлены секторы на поверхности породных отвалов угольных разрезов Канско-Ачинского угольного бассейна, в которых наиболее масштабно проявляется воздействие водной эрозии на формирование рельефа рекультивированных горнопромышленных ландшафтов.

Ключевые слова: добыча угля открытым способом, породные отвалы, горнопромышленные ландшафты, формирование оврагов.

В угледобывающих регионах Центральной и Восточной Сибири формируется новый тип техногенных ландшафтов - горнопромышленные ландшафты в виде рекультивированных породных отвалов. Результаты полевых экспедиций по изучению состояния последних в районах с масштабной добычей угля открытым способом указали на снижение качественных и количественных характеристик рекультивированного почвенного слоя относительно природных ландшафтов. Потери плодородных почвенных слоев при добыче угля открытым способом находятся на уровне 85-90\%. К настоящему времени горизонтальные поверхности породных отвалов, рекультивированных под пашню, деформированы усадочными процессами, произошедшими в теле отвалов. Кроме того, выявлены обстоятельства и многочисленные факты разрушения целостности рельефа породных отвалов образующимися оврагами. Оврагообразование сопровождается постоянным изменением морфологического состава пород, участвующих в формировании рельефа горнопромышленных ландшафтов. Как это ни парадоксально, но наиболее масштабно процесс оврагообразования проявляется на породных отвалах с идеально спланированной горизонтальной поверхностью.

Породные отвалы, отсыпанные при разработке месторождений Канско-Ачинского угольного бассейна (рuс. 1), вскрышная толща которых сложена рыхлыми горными породами, разрабатываемыми без применения буровзрывных работ, наиболее подвержены воздействию водной эрозии.

Морфологический состав породных отвалов угольных разрезов Канско-Ачинского бассейна представляет собой техногенную смесь из вскрышных пород (суглинки, супеси, глины, почвенные слои, углистые аргиллиты, уголь при зачистке пластов, песчаники и т.п.). Большой удельный вес четвертичных (мягких) отложений (75-85\%) в структуре пород отвала, интенсивное таяние снежного покрова на поверхности отвала, летние затяжные ливневые дожди способствуют интенсивному разрушению целостности рельефа отвалов под влиянием водной эрозии. В результате экологическое равновесие, формирующееся на рекультивированных отвалах, нарушается.

На разрезе «Березовский» породные отвалы отсыпают с 1974 г. Пионерные внешние отвалы имеют устойчивый рельеф. К настоящему времени в секторе производства горных работ в выработанном пространстве разреза размещен внутренний породный отвал, который разрушается водными потоками (см. рис. 1, а, центральный сектор). Водная эрозия формирует поверхность породного отвала в виде многочисленных водопропускных канав сечением от 1 до 3,5 м². Комбинация канав имеет в плане вид сетки. Поскольку воздействие эрозии постоянное во времени, то и растительность в этом секторе полностью отсутствует. Также на территории внутренних отвалов имеются одиночные промоины на откосах. Всего на территории разреза имеются 151 канава и 17 мелких оврагов.

На разрезе «Назаровский» породные отвалы отсыпают с 1950 г. В настоящее время добыча угля производится на двух участках угольного месторождения, которые в перспективе должны сомкнуться в один карьер. На месте отработанного угольного пласта также размещают внутренние 

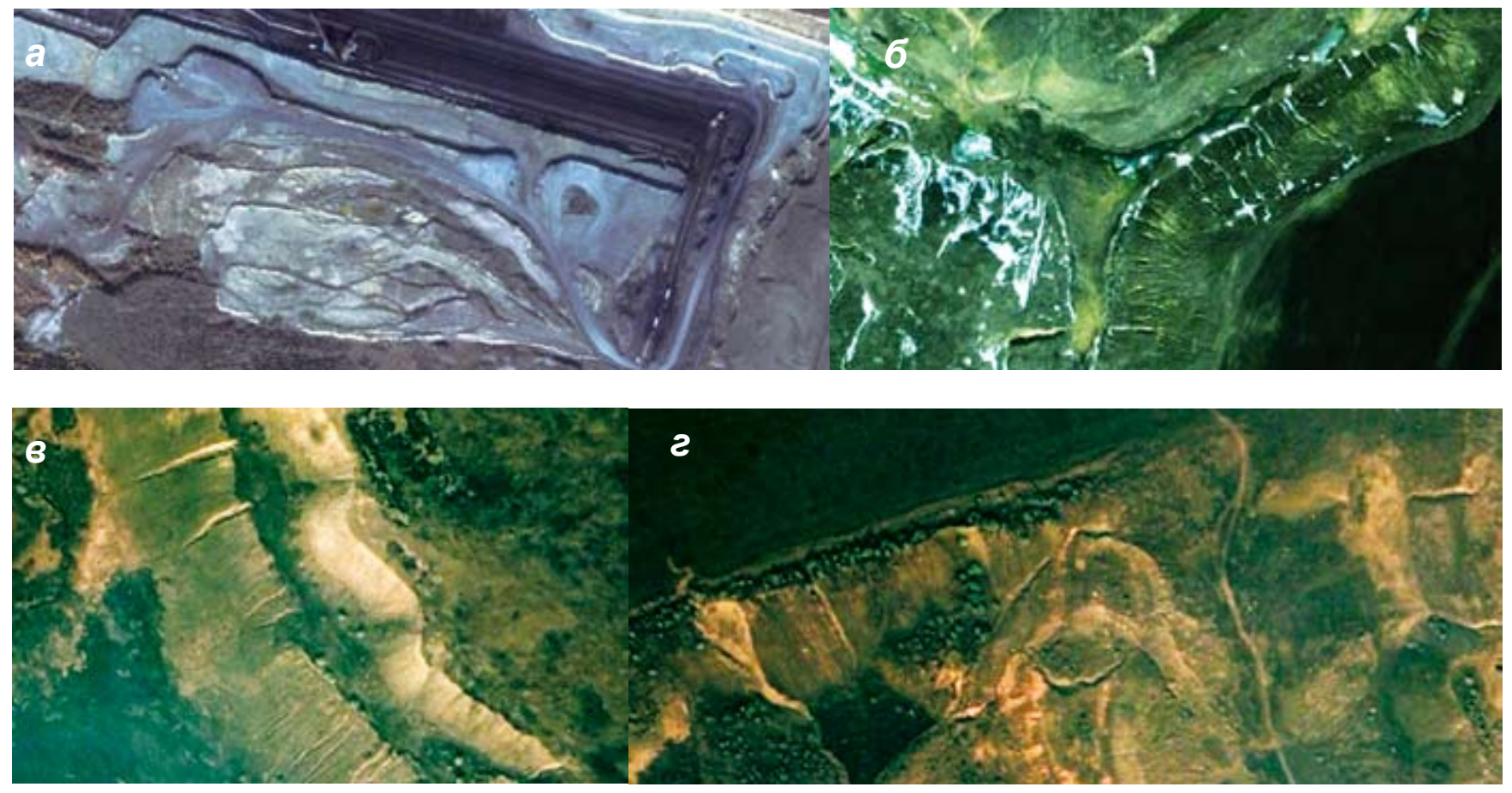

Pис. 1. Горнопромышленные ландшафты на породных отвалах угольных разрезов, формируемые при воздействии водной эрозии: $a$ - внутренний отвал разреза «Березовский», б - внутренние отвалы разреза «Назаровский»,

в- внешний отвал «Северный» разреза «Бородинский», г - внешний отвал «Западный» разреза «Бородинский».

отвалы вскрышных пород. На отработанной части месторождения сформирован горнопромышленный ландшафт, состоящий из следующих элементов рельефа. Нерабочий борт карьера засыпан инертной подушкой из вскрышных пород с углом откоса до $30^{\circ}$. Откосы внутренних отвалов сочленяются в плане с откосом насыпи над угольным пластом. В результате образуется локальное понижение рельефа, в котором скапливаются талые и дождевые воды. Последние представляют собой концетрированные водные потоки, размывающие откосы техногенного рельефа (см. рис. 1, б). В этой части горизонтальные поверхности внутренних отвалов спланированы на разных высотных отметках, поэтому искусственно формируются значительные водосборные площади, с которых талые и дождевые водотоки переливаются с более высоких плато на менее низкие. Всего на территории горнопромышленного ландшафта, созданного в период с 1970 по 1995 г., действует 21 овраг, формирующий вторичный рельеф и более 100 водопропускных мелких канав, принимающих участие в трансформации рельефа.

На разрезе «Бородинский» породные отвалы отсыпают с 1950 г., на них широко распространены начальные эрозионные формы в виде промоин (рытвин), приуроченные к откосам незадернованных склонов отвалов. В плане такие эрозионные формы имеют линейную форму на откосах и извилистую - на поверхности отвалов (см. puc. 1, в, г). Генеральный продольный профиль их соответствует направлению и форме склона, на котором они развиты. Всего на откосах и поверхности отвалов насчитываются 34 промоины, самые крупные из которых дали начало активному формированию локальных овражно-балочных систем.

На протяжении ряда лет (с 2000 г.) на разрезе «Бородинский» систематически отслеживалось формирование двух наиболее крупных оврагов - на внутреннем отвале в выработанном пространстве разреза и на внешнем отвале «Западный» (см. рис. 1, 2, левый сектор и рис. 2).
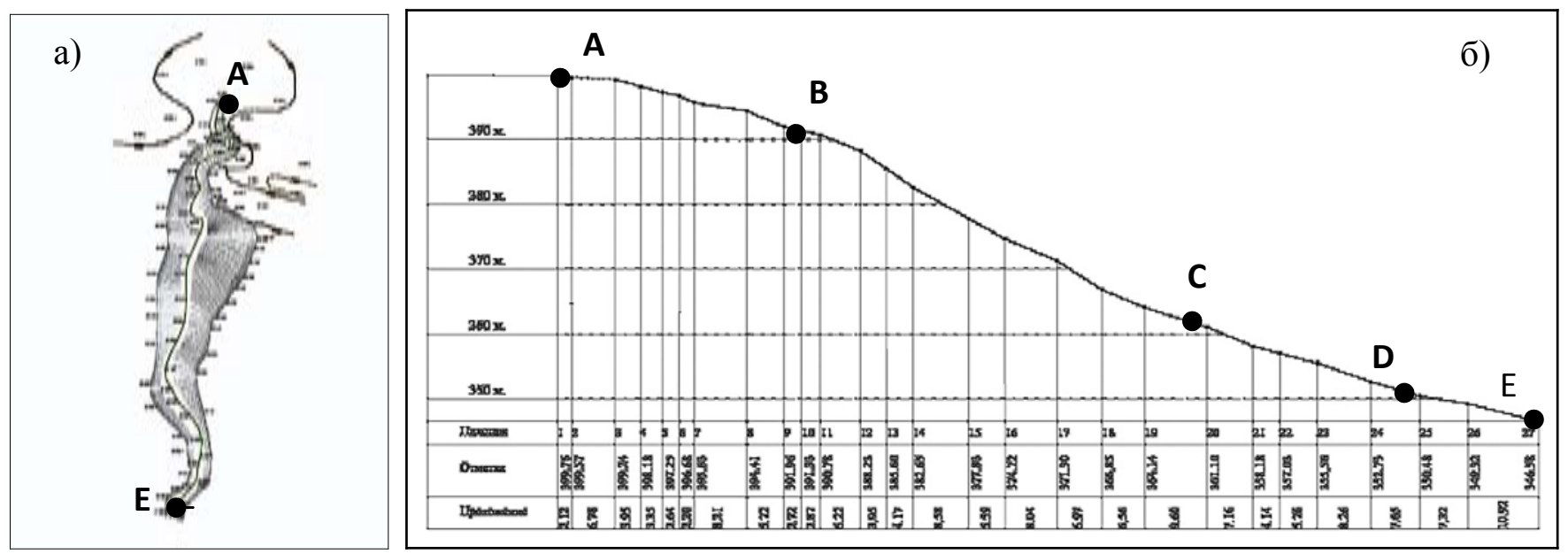

Рис. 2. План (а) и продольный профиль (б) оврага на южном склоне внешнего отвала «Западный» (разрез «Бородинский») 
Таблица 1 из тела породного отвала. Результатыпред-

Характеристики оврага на отвале «Западный»

\begin{tabular}{|c|c|c|c|c|}
$\begin{array}{c}\text { Участок } \\
\text { профиля }\end{array}$ & $\begin{array}{c}\text { Перепад } \\
\text { высот, м }\end{array}$ & $\begin{array}{c}\text { Длина горизон- } \\
\text { тальной проекции } \\
\text { участка, м }\end{array}$ & $\begin{array}{c}\text { Угол участка } \\
\text { дна оврага, } \\
\text { град }\end{array}$ & $\begin{array}{c}\text { Форма } \\
\text { сочленения } \\
\text { откосов }\end{array}$ \\
\hline AB & 10 & 40 & $13-14$ & Щелевая \\
\hline BC & 25 & 50 & $26-27$ & Трапециевидная \\
\hline CD & 12 & 32 & $19-21$ & Траншейная \\
\hline DE & 5,5 & 26 & $11-12$ & Траншейная \\
\hline
\end{tabular}

Объемы загрязняющих веществ, попадающих

в атмосферу при горении углесодержащих пород при их выносе из породных отвалов (разрез «Бородинский»)

\begin{tabular}{|c|c|c|c|c|c|c|}
\hline Год & $\begin{array}{c}\text { Количество } \\
\text { оврагов }\end{array}$ & $\begin{array}{l}M_{\mathrm{co}^{\prime}} \\
\text { т/год }\end{array}$ & $\begin{array}{l}M_{\text {SO2' }} \\
\text { т/год }\end{array}$ & $\begin{array}{l}M_{\text {H2S' }} \\
\text { т/roд }\end{array}$ & $\begin{array}{l}\mathrm{M}_{\text {NOx' }} \\
\text { T/rOд }\end{array}$ & $\begin{array}{c}\mathbf{M}_{\mathrm{C2OH} 12^{\prime}} \\
\text { кг/год }\end{array}$ \\
\hline 2000 & 19 & 81,1 & 1,04 & 2,07 & 0,0038 & 6,18 \\
\hline 2005 & 35 & 366,6 & 4,68 & 9,36 & 0,0173 & 27,92 \\
\hline 2008 & 37 & 599,3 & 7,65 & 15,31 & 0,0282 & 45,65 \\
\hline 2010 & 38 & 726,2 & 9,27 & 18,54 & 0,0342 & 55,31 \\
\hline 2013 & 40 & 909,5 & 11,61 & 23,22 & 0,0428 & 69,27 \\
\hline
\end{tabular}

По состоянию на 30.11.2013 архитектура оврага выглядит следующим образом (см. рис. 2). Его глубина составляет 53 м, длина - 150 м. Створ (поперечное сечение) меняется на всем его протяжении. Участок AB расположен в теле отвала, его начало расположено на расстоянии $30 \mathrm{M}$ от откоса отвала. На этом участке водные потоки сливаются вниз по стенкам оврага и затем, вымывая грунт отвала, движутся вниз по участку ВС. Этот участок имеет более крутые углы откосов. На нем водным потоком происходят вертикальное прорезание дна оврага и вымывание грунта. На участках $C D, D E$ по водосбросной траншее вымытый грунт перемещается далее на природный ландшафт и в природные водоемы.

Геометрические параметры оврага на внешнем отвале «Западный» разреза «Бородинский» представлены в табл. 1

На протяжении 2000-2013 гг. на породных отвалах разреза «Бородинский» проводился экологический мониторинг загрязнения воздушного бассейна газами, образующимися в результате свободного горения на атмосферном воздухе углесодержащих пород, вынесенных водотоками
Таблица 2

ставлены в табл. 2.

Результаты наших исследований на породных отвалах разреза «Бородинский» отражают экологическую картину на подобных угольных предприятиях с вероятностью 92-95\%, поскольку все без исключения технологии ведения горных работ на разрезах «Березовский», «Назаровский», «Переясловский» предусматривают зачистку кровли угольного пласта. В дальнейшем смесь угля с покрывающими угольный пласт вскрышными породами размещается в теле породного отвала. С вероятностью $92-95 \%$ можно рассмотреть адекватное загрязнение воздуха горящим углем. По нашей оценке, в результате водной эрозии на породных отвалах трёх разрезов, как ее следствие в атмосферный воздух попадает в течение календарного года: оксида углерода - 3150 т, оксида серы - 35-36 т, сероводорода - 66-68 т, оксидов азота - 0,12-0,14 т, бензапирена - 230 кг.

Итак, современное состояние горнопромышленных ландшафтов в виде рекультивированных углепородных отвалов можно оценить как экологически не благополучное, поскольку установлено, что целостность рельефа отвалов систематически разрушается под влиянием водной эрозии, сокращаются площади рекультивированных породных отвалов, на которых с течением времени начинают свое формирование молодые экосистемы. Также сокращаются площади природных ландшафтов, находящихся в зоне выноса горных пород, перемещенных водными потоками из тела породного отвала. Кроме того, происходит систематическая эмиссия вредных отравляющих газов, образующихся при горении углесодержащих пород.

В этой связи необходимы конструктивные инженерные решения в области разработки технологий формирования и рекультивации углепородных отвалов, представляющих наземные экосистемы - устойчивые во времени к разрушению в результате воздействия природных факторов, таких как проявление водной эрозии.

Title

ENVIRONMENTAL EFFECTS OF RELIEF DESTRUCTION OF COAL MATERIAL DUMPS UNDER THE INFLUENCE OF NATURAL FACTORS

Authors

Zenkov I.V., Shchadov I.M., Nefedov B.N.

\section{Authors' Information}

Zenkov I.V., doctor in technical sciences, "Nauka" Special design-technology office of KSC SB RAS, professor of FSAEI HPO "Siberian federal university", Krasnoyarsk, Russia, e-mail: zenkoviv@mail.ru

Shchadov I.M., doctor in technical sciences, professor of FSBEI HPO "Irkutsk state technical university", Irkutsk, Russia

Nefedov B.N., ph.d in technical sciences, "Nauka”Special design-technology office of KSC SB RAS, Berdsk, Russia

\section{Abstract}

Coal rock dumps were dumped in great amount during the open pit coal mining since 1950 in Siberia coal-mining regions. Many years of field expeditions found out that the waste dumps are destroyed under the influence of water erosion, leading to numerous cloughs. At the dumping stage of stripping soils the coal containing solids are inserted in the body of coal rocks, when washed by the water, they begin spontaneously ignition contacting the atmospheric air. There were identified the sectors on the surface dumps of coal cuts in Kansk-Achinsk coal basin, with the most evident effects of massive water erosion on the reclaimed relief formation of the mining landscapes.

Keywords

Open-Pit Coal Mining, Pit Heaps, Mining Landscapes, Clough Forming. 


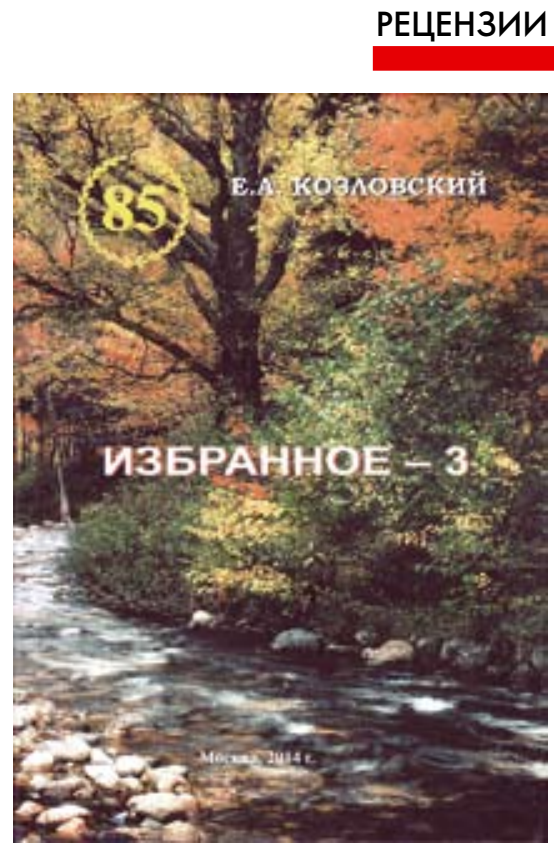

\section{Козловский Е. А. Избранное-З. Минерально-сырьевые ресурсы России (анализ, прогноз, политика). Публикации в прессе (2009-2014 г2.). М.: ВНИИгеосистем, 2014. 636 c.}

Вышедшая из печати книга выдающегося геолога, заслуженного деятеля науки и техники РСФСР, заслуженного геолога России, лауреата Ленинской и Государственныхпремий, Министра геологии СССР (1975-1989гг.), вице-президента РАЕН, члена коллегии Высшего горного совета России, профессора, доктора технических наук Е.А. Козловского «Избранное - 3. Минерально-сырьевые ресурсы России (анализ, прогноз, политика)» представляет уникальныйтруд, в котором собран и обобщен богатый материал, полученный из средств массовой информации и в результатемноголетней работы автора по проблеме минерально-сырьевых ресурсов не только в нашей стране, но и в разных странах мира.

Используя свой богатейший опыт, накопленный в процессе научной и практической деятельности, автор поставил важнейшую задачу: провести всесторонний анализ существующего экономического положения в стране для обеспечения ее безопасности, в условиях глобального экономического кризиса не только в России, но и во всем мире. Результаты этого анализа приведены в данной обобщающей монографии. Автор показал, что существующий кризис можно преодолеть за счет развития минерально-сырьевой базы, особенно при освоении крупнейших разведанныхместорождений России. В частности, только за счет разработки крупного Удоканского месторождения, содержащего $3 \%$ ценного компонента (меди), можно получить несколько сотен млрд руб. прибыли. А таких месторождений, уже подготовленных к освоению в различных районах страны, у нас десятки. Это большой потенциал для развития экономики России.

Автор показал, что Россия обладает огромными минеральными природными ресурсами, которые могут служить прочным фундаментом не только для развития существующей экономики, но и для ее дальнейшего быстрого роста. С созданием новых горно-обогатительных предприятий экономический потенциал страны должен возрасти.

По добыче нефти, газа, производства стали и чугуна, первичного алюминия, рафинированной меди, никеля, цинка, титана наша страна занимает первое место в мире, это главная составляющая всестороннего и быстрого развития отечественной промышленности, что и обосновывает автор в своей монографии.

В данной работе автор анализирует и другие аспекты экономики России, подробно рассматривается проблема экономической безопасности страны, показана значимость минерально-сырьевой базы в ее обеспечении, большое внимание уделяется системному экономическому кризису и путям выхода из него. Это первое детальное обобщение по данному вопросу, которое позволяет расширить знания и улучшить представление о минерально-сырьевой базе и ее влиянии на развитие страны.

В результате анализа имеющегося материала по экономике и минерально-сырьевой базе страны автор приходит к выводу о необходимости создания в России Госкомитета по геологии и недропользованию с целью дальнейшего расширения поисков и разведки новых месторождений.

В работе большое внимание уделено известным геологам, внесшим существенный вклад в теорию и практику изучения недр Земли. Труды этих ученых дают возможность расширить фронт работ в области поисков новых месторождений с целью обеспечения безопасности страны.

Перечень публикаций Е.А. Козловского показывает, что автор является крупным ученым мирового масштаба, который хорошо знает не только теоретические аспекты горно-геологической отрасли, но и дает практические рекомендации по решению ее проблем.

Таким образом, труд Е. А. Козловского является ценным вкладом в изучение экономики и минерально-сырьевой базы, способствует формированию геологической стратегии укрепления экономического потенциала страны, а также повышению уровня научного потенциала специалистов в освоении и изучении новых месторождений.

Рекомендуем всем специалистам, работающим в области освоения и развития минерально-сырьевой базы, широко использовать этот труд в своей повседневной работе. Существующие в данной монографии ценные предложения и рекомендации позволят производственникам быстрее преодолеть существующий кризис и поднять экономику нашей страны на качественно новый уровень.

Данная работа ценна для молодых специалистов, студентов, преподавателей вузов. Она будет способствовать ускорению процесса формирования новых специалистов и служить настольной книгой для геологов-практиков.

В.А. Рафиенко, Заведующий лабораторией МГРИ-РГГРУ, кандидат техн. наук, доктор философии по экономике PhD 


\section{Tlоздравляем!}

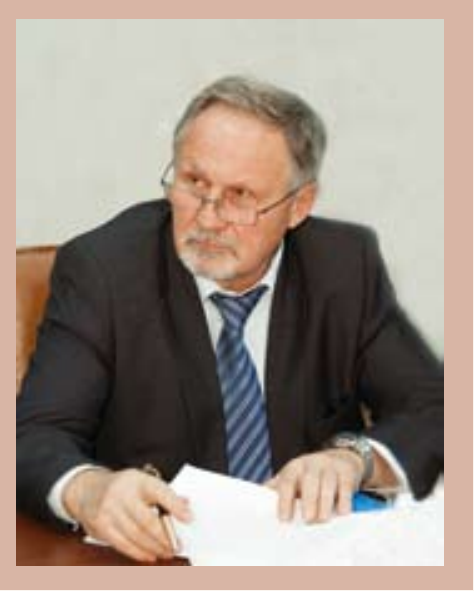

\section{КЛИШИН Владимир Иванович}

\section{(к 65-летию со дня рождения)}

11 декабря 2014 г. исполняется 65 лет со дня рождения известного специалиста в области горного дела, доктора технических наук, профессора, члена-корреспондента РАН, Заслуженного изобретателя $Р Ф$, действительного члена Академии горных наук, директора ИУ СО РАН Владимира Ивановича Клишина.

Трудовой стаж Владимира Ивановича Клишина составляет более 40 лет. После окончания в 1972 г. Томского политехнического института он начал работать в Институте горного дела СО РАН и прошел путь от инженера до заместителя директора по научной работе ИГД СО РАН.

В 2011 г. В.И. Клишин возглавил Институт угля Сибирского отделения Российской академии наук. Только за последнии годы под руководством В.И. Клишина были проведены исследования взаимодействия механизированных крепей с вмещающими породами угольного пласта, обоснованы технологические решения разработки мощных пологих и крутых угольных пластов с управляемым и регулируемым выпуском угля, разработана технология разрушения труднообрушаемых кровель методом направленного гидроразрыва горного массива, а также техника и средства ее реализации, создано уникальное оборудование для проведения дегазационных, технологических скважин, предложены нетрадиционные решения добычи кимберлитовых алмазосодержащих руд Республики Саха (Якутия).

Владимир Иванович активно занимается подготовкой научных кадров. Среди его учеников 8 кандидатов наук. Он является автором и соавтором более 300 научных работ и 100 авторских свидетельств СССР, патентов на изобретение и полезные модели РФ.

Профессиональная и общественная деятельность Владимира Ивановича Клишина включает в себя участие в работе Объединенного ученого совета наук о Земле СО РАН, Бюро научного совета РАН по проблемам горных наук, рабочей группы Минэкономразвития России, Президиума Кемеровского научного центра СО РАН, редакционного совета издательства журнала «ФТПРПИ», «Вестник КузГТУ», «Горная книга», «Рудник будущего», Академии горных наук . В.И. Клишин является Президентом НП «Ассоциация машиностроителей Кузбасса», Научно-технического совета Группы предприятий ЗападноУральского машиностроительного концерна (ГП ЗУМК).

Многолетний и плодотворный труд, большой личный вклад в развитие угольной науки и промышленности В.И. Клишина отмечен достойными наградами.

Коллектив Института угля Сибирского отделения РАН, редколлегия и редакция журнала «Уголь» от всей души поздравляют Владимира Ивановича Клишина с юбилеем и желают ему дальнейшего успешного продвижения в науке, открытого горизонта новых идей, воплощения научной мечты, силы духа и крепости тела, сибирского здоровья, семейного благополучия!

КНИЖНАЯ НОВИНКА

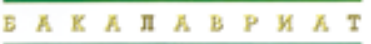

B.M. Taus

IIPIP0I00XРАНHЫE

TEXH0:ОГПIII РАЗРАБОТКИ

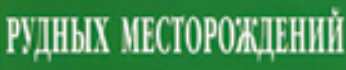

У ЧЕ ВНО
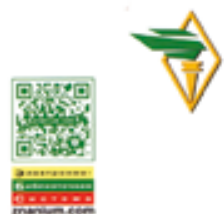

Код - 438650.01.01.
Научно-издательский центр «ИНФРА-М» Учебные пособия для студентов и преподавателей вузов, горных инженеров и широкого круга читателей

Природоохранные технологии разработки рудных месторождений

Учебное пособие / В.И. Голик. М.: ИНФРА-М, 2014. 192 с. (Высшее образование: бакалавриат). ISBN 978-5-16-006749-0.

Допущено Учебно-методическим объединением вузов Российской Федерации по образованию в области горного дела в качестве учебного пособия для студентов высших учебных заведений, обучающихся по направлениям подготовки «Горное дело».

В учебном пособии изложены аспекты добычи полезных ископаемых в рамках учебных программ для студентов горных и геологических специальностей. В центре внимания вопросы влияния горного дела на биосферу и техногенное изменение экосфер Земли в результате взаимодействия горного дела и недр. Рассматриваются история, темпы развития и перспективы природоохранных технологий добычи полезных ископаемых, в том числе полнота и комплексность использования минеральных ресурсов.

\section{Где купить:}

Оптовая продажа по безналичному расчету: Отдел по работе с библиотеками вузов и ссузов Тел.: (495) 363-4260 (доб. 230, 225, 226, 228)

E-mail: nadin@infra-m.ru; seller@infra-m.ru

\section{Книга-почтой:}

Тел.: (495) 363-4260 (доб. 246)

Факс: (495) 363-4260 (доб. 232)

E-mail: podpiska@infra-m.ru 


\section{угольная энергетическая компания» Владимир Рашевский возглавил рейтинг высших руководителей}

Генеральный директор ОАО «Сибирская угольная энергетическая компания» Владимир Рашевский возглавил рейтинг высших руководителей в категории «Энергетика и топливный бизнес», по версии издания «Коммерсантъ».

В «Топ-1000 российских менеджеров» также вошли директор СУЭК по экономике и финансам Кузьма Марчук, коммерческий директор Игорь Грибановский, руководитель департамента корпоративной политики и специальных проектов Сергей Твердохлеб, директор по связям и коммуникациям Сергей Григорьев и директор по информационным технологиям Дмитрий Сиземов.

Ежегодно «Коммерсантъ» выявляет наиболее профессиональных управленцев высшего эшелона, достигших выдающихся результатов в управлении и оказавших значительное влияние на российскую экономику. В основе методологии построения рейтинга лежит принцип «Лучшие выбирают лучших»: топ-менеджеры оценивают топ-менеджеров, управленцы по направлениям, соответственно, управленцев других компаний. Узнать более подробную информацию о своих коллегах и оценить их работу менеджеры могут на сайте www. top1000.amr. ru. Окончательные итоги рейтинга утверждаются на заседаниях экспертных комиссий с участием всех желающих кандидатов «Топ-1000» текущего года и многократных кандидатов рейтинга прошлых лет.

И еще: после опубликования списка наиболее эффективных менеджеров 2013 года эксперты решили составить портрет «идеального управленца». По полученным среднестатистическим данным, это мужчина, средний возраст которого 43 года, «приезжий» — не из Москвы и Санкт-Петербурга. Он женат, у него двое детей. Как правило, имеет непрофильное по отношению к настоящей занимаемой должности первое высшее образование, которое часто компенсируется последующим получением диплома в сфере экономики и управления или дипломом МВА (последний есть у каждого пятого). Средний стаж на текущем месте работы - 8 лет.

Источник: НИА (2. Красноярск), 19.09.2014

\section{Предприятия СУЭК получили награды за высокую социальную эффективность}

ООО «Назаровское горно-монтажное наладочное управление» стало победителем краевого смотра-конкурса «За высокую социальную эффективность и развитие социального партнерства» среди предприятий угольной промышленности по итогам 2013 года. На втором месте - ЗАО «Разрез Назаровский». Награждение проходило в правительстве Красноярского края. Награды победителям вручил и. о. заместителя председателя правительства Виктор Зубарев.

«Краевой конкурс уже стал по-настоящемудоброй традицией Красноярского края. Ежегодно мы называем лучших в сфере социального партнерства - и среди органов власти, и среди предприятий и организаций региона. Многие из них поддерживают высокий статус на протяжении ряда лет - постоянно оказываясь в числе призеров смотраконкурса. Это настоящий актив, позволяющий Красноярскому краю по правунаходиться в числе наиболее социально ориентированных регионов России, регионов, где власть, общество и бизнес считают своим главным принципом внимание кчеловеку, кразвитию его потенциала, краскрытию трудовых и культурных способностей», - отметил Виктор Зубарев.
ООО «Назаровское ГМНУ» и ЗАО «Разрез Назаровский» ежегодно входят в тройку победителей конкурса, подтверждая свой статус предприятий с высокой социальной ответственностью.

«Технический прогресс - это, прежде всего, люди, - твердо убежден исполнительный директор ООО «Назаровское ГМНУ» Николай Бережецкий, - поэтому к ним на нашем предприятии, как и в целом в СУЭК, - особое внимание. тому же в этом году наш дружный коллектив «прирос» сотрудниками ремонтно-механического завода, а это значит, ответственности стало больше. Что касается победы в конкурсе, эта награда - показатель того, что мы идем в верном направлении, и стимул работать еше лучше».

Отметим, что при подведении итогов конкурса учитывались такие показатели развития, как средняя заработная плата сотрудников, индексация заработной платы, затраты предприятия на оздоровление и отдых, улучшение условий и охрану труда, на спортивно-оздоровительные и культурно-массовые мероприятия, деятельность по переподготовке и повышению квалификации кадров.

Источник: ИА Запад 24 (2. Назарово) , 07.10.2014 


\section{IV Международная конференция}

\section{«Рынки угля в странах Средиземного моря»}

С 15 по 16 сентября 20142. в Стамбуле, деловой и финансовой столице Турции, проходила IV Международная конференция «Рынки угля 6 странах Средиземного моря".

Форум был посвящен актуальным вопросам угольной торговли в странах Средиземного моря, последним тенденциям и инновациям в энергетическом секторе, а также перевозкам угля в регионе.

На мероприятии активно обсуждались вопросы добычи и потребления угля в Европе, Средиземноморье, странах Черного моря, а также динамика угольной торговли через бассейны Атлантического и Тихого океанов. Отдельное внимание было уделено вопросам конкуренции газовой и угольной генерации в Европе, а также доле угля в топливном балансе при производстве цемента и электроэнергии. В конце первого рабочего дня организатором конференции, компанией «Бизнес-Форум», была организована культурная программа, где участники имели прекрасную возможность непринужденно пообщаться и установить новые знакомства.

Конференция стартовала 15 сентября с приветственного слова первого заместителя министра энергетики и угольной промышлен-
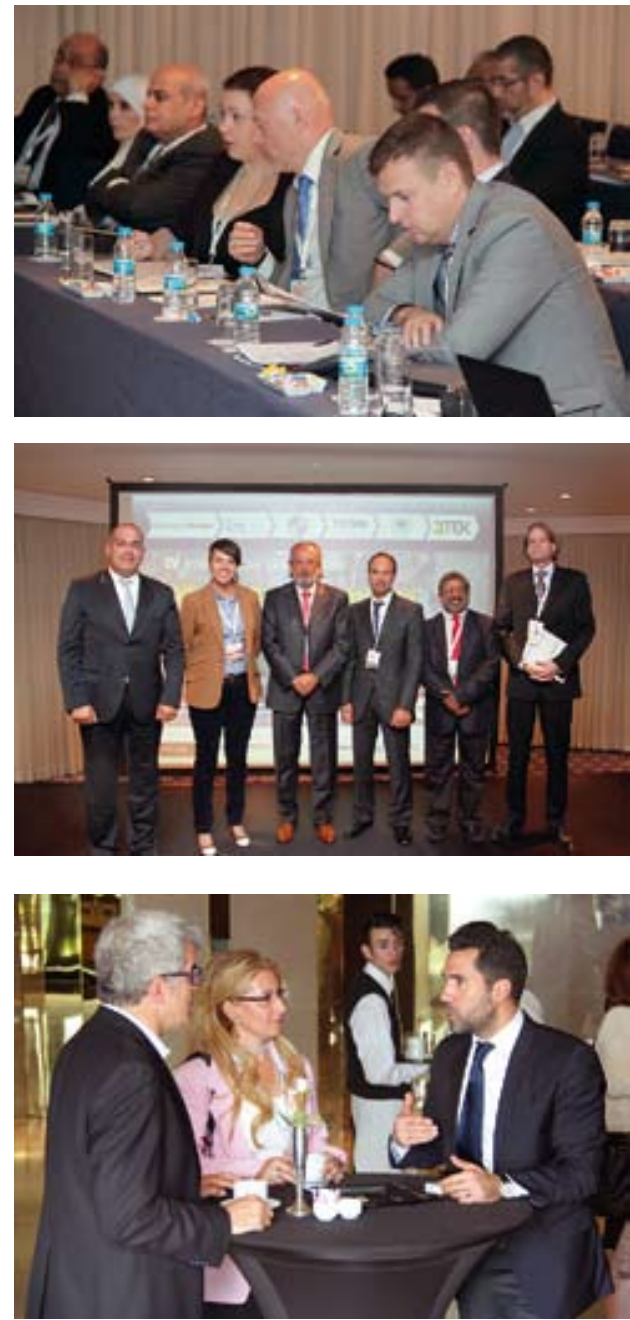
ности Украины Юрия Зюкова. Он рассказал о состоянии угольного рынка Украины, проблемах с добычей и транспортировкой угля и перспективах угольной и энергетической генерации, отметил значительное сокращение добычи угля в Украине и в связи с этим рост импорта энергетического угля в страну.

Врамкахпервой сессии был рассмотрен мировойрынок энергетического угля. В частности обсуждалась динамика угольной торговли в Атлантическом и Азиатско-Тихоокеанском бассейнах, текущее избыточное предложение на рынках и прогноз цен на 2015 г., конкуренция между углем и газом в краткосрочной перспективе, фрахтовые ставки, наличие флота класса Coaster и сезонные колебания в бассейнах Черного и Средиземного морей. Свои доклады в сессии предоставили ведущие эксперты из International Energy Agency, LBH Turkey, Mercuria Energy Trading и Wood Mackenzie.

Вторая сессия конференции была посвящена экспорту угля в регион Средиземного моря. Были рассмотрены как основные поставщики, так и потенциально новые игроки рынка. Свои презентации о текущем состоянии и развитии экспорта из Колумбии, США и Польши провели представители компаний Commonwealth Coal Marketing, Prairie Downs Metals и Trafigura.
В завершение дня рассматривались вопросы угольной генерации и потребления сортового угля для коммунальных нужд. В сессии по энергогенерации активно обсуждался запуск новых электростанций, угольный баланс, генерация на местном лигните и связанные с этим вопросы логистики. Прозвучали доклады от представителей Ciner Group, Deloitte, Iskenderun Energy, Public Power Corporation of Greece. В рамках сессии по сортовому углю была затронута тематика основных поставщиков, рынков сбыта и связанных с ними потребительских предпочтений в регионе Средиземного моря. Своей экспертизой с участниками поделились ведущие трейдеры из HMS Bergbau, Sumo Coal / Horizon Enerji, Super Enerji.

По завершении первого рабочего дня состоялась поездка в музей под открытым небом «Миниатюрк» и прогулка на корабле по проливу Босфор.

Во второй рабочий день конференции рассматривались вопросы потребления угля, нефтяного кокса и альтернативного топлива в цементной отрасли. Также на уровне специальной темы были озвучены возможности поставок коксующегося угля и кокса из Польши в регион.

Сессия по производству цемента в Турции и странах MENA дала участникам возможность ознакомиться с актуальной информацией о поставках и потреблении топлива. Внимание уделялось кактрадиционным источникам (уголь и нефтяной кокс), так и перспективам внедрения альтернативного топлива, получаемого при переработке твердых отходов. Отдельно освещались вопросы импорта угольной продукции и роста объемов производства цемента и клинкера как стимулятора рыночных цен на топливо.

Своим видением развития ситуации на рынках поделились специалисты из компаний Capex Industries, HC Trading, Lafarge Cement, MVW Lechtenberg \& Partner, Qatrana Cement, Saif Enerji, Sambudrol и из Турецкой ассоциации производителей цемента / ТСМА.

Подводя итоги конференции, можно отметить, что форум стал популярной и узнаваемой торговой площадкой для встреч ключевых игроков региона Средиземного моря. Здесь гости получают возможность не только провести важные переговоры и узнать реальные тенденции развития рынка, но также провести время в приятной компании друзей и партнеров.

Пресс-центр компании «Бизнес-Форум» www. b-forum. com 


\section{Угольная промышленность Украины в период 2000 - 2014 гг.}

\author{
ПЛАКИТКИНА Людмила Семеновна \\ Зав. лабораторией научных основ развития \\ и регулирования угольной и торфяной \\ промышленности института ИНЭИ РАН \\ Москва, Россия, e-mail: luplak@rambler.ru
}

В статье проанализированы в период с 2000 по 2013 г. и с января по август 2014 г.: добыча, экспорт и импорт коксующегося и энергетического угля в Украине; рассмотрено территориальное развитие предприятий по добыче угля в Украине; обозначены основные частные компании, работающие в угольной отрасли Украины, а также проанализированы потребление и выработка электроэнергии в Украине, производство, экспорт и импорт кокса, цены на кокс и коксующийся уголь.

Ключевые слова: добыча угля, экспорт угля, импорт угля, потребление угля, выработка электроэнергии, производство кокса, чены на кокс, цены на коксующийся уголь.

\section{ДОБЫЧА КОКСУЮЩЕГОСЯ И ЭНЕРГЕТИЧЕСКОГО УГЛЯ В УКРАИНЕ, ДОТАЦИИ В ОТРАСЛЬ}

По запасам угля Украина занимает седьмое место в мире (после США, России, Китая, Индии, Германии и Казахстана). Доказанные запасы угля в Украине - 33,9 млрд т (3,9\% мировых запасов), из которых 15,4 млрд т - антрацита и битуминозного угля, 18,5\% - бурого угля. Доля угля в топливном балансе электрогенерирующих предприятий Украины составляет около $38 \%$.

В 2013 г. общий объем добычи рядового угля в Украине составил 83,7 млн т (темп роста к уровню 2000 г. - 104,6\%), из них на государственных шахтах - 24,1 млн т, что меньше на 2,6\% по сравнению с уровнем 2012 г.

Добыча коксующихся углей в Украине в 2013 г. составила 23,7 млн т (на 14,8\% ниже уровня 2000 г.), а энергетическихуглей - 59,97 млнт (на $15 \%$ выше, чем в 2000 г.). Доля коксующегося угля в Украине в 2013 г. - 28,3\%, энергетического - 71,7\% (рис. 1).

В первом полугодии 2014 г. в Украине было добыто 40,6 млн т (на 0,5\% меньше аналогичного показателя 2013 г.), в том числе в июне - 6,1 млн т. Однако уже в июле 2014 г. производство угля на шахтах Донбасса, которое обеспечивало около 70\% потребления электроэнергии в Украине, упало на 900 тыс. т, а в августе текущего года по отношению к июлю текущего года сократилось еще на $44 \%$ в связи с военными действиями. Возникли сложности с транспортировкой угля на склады тепловых электростанций.
Из-за боевых действий и причиненного ущерба промышленной инфраструктуре добыча угля, по состоянию на 19 сентября 2014 г., осуществлялась только на 28 из 93 государственных шахт Украины, а 68 шахт — остановлены и работают в режиме жизнеобеспечения, т.е. откачивают воду. Суммарные производственные мощности оставшихся работающих шахт не позволяют покрыть потребность страны в этом виде топлива, и в ближайшие годы Украина не сможет заменить российский газ углем собственной добычи. С августа 2014 г. в Украине начались перебои с поставками угля - одного из основных энергоносителей.

Шахтный фонд в Украине - достаточно старый, себестоимость добычи угля - высокая. Поэтому каждый год Правительство Украины выделяло дотации угольной отрасли, объемы которых из года в год возрастали. В 2013 г. они составили 15 млрд гривен (около 2 млрддол. США). В августе 2014 г. Рада Украины приняла решение о сокращении в текущем году дотаций предприятиям угольной отрасли Украины на 180 млн гривен - до 11,988 млн гривен, которые, в основном, направлялись на покрытие расходов по себестоимости готовой товарной продукции и инвестировались в техническое переоснащение угольных предприятий. В сентябре 2014 г. Президент Украины подписал соответствующий закон.

В ближайшем будущем в связи с требованием МВФ о закрытии нерентабельных предприятий и проведении приватизации, дотации государственным шахтам будут полностью прекращены. В соответствии с требованиями МВФ, кредитующего Украину на очень жестких условиях полной приватизации государственных шахт, которую много лет в силу разных причин, не могли осуществить власти страны, теперь уже никак не избежать.

Согласно программ реструктуризации угольной промышленности Украины, разработанной Правительством

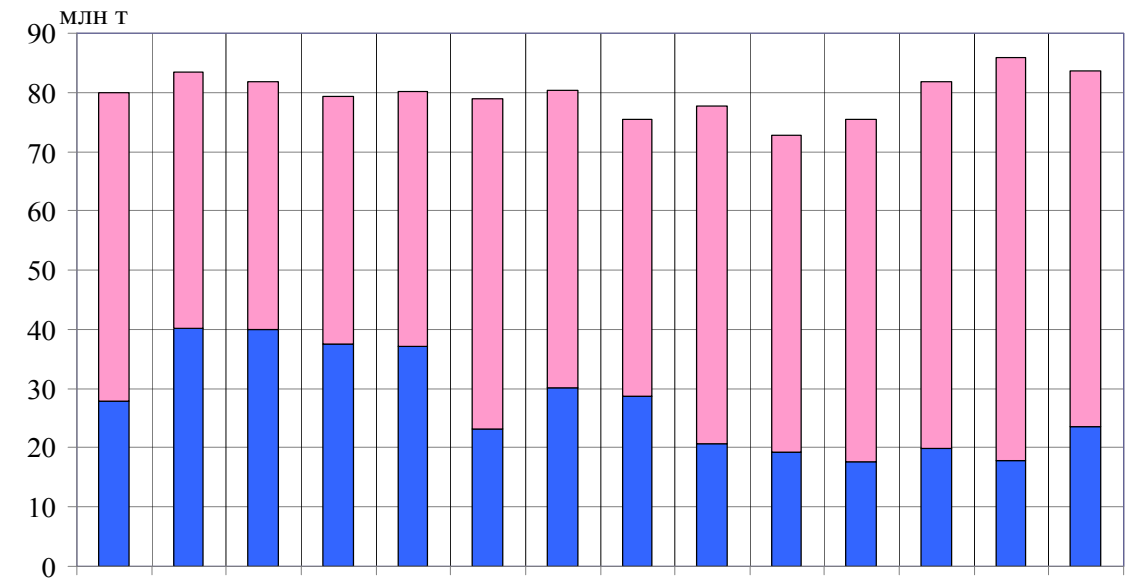

20002001200220032004200520062007200820092010201120122013 $\square$ Коксующиеся угли $\square$ Энергетические угли

Pис. 1. Добыча коксующегося и энергетического угля в Украине за 2000-2013 г2. 
и представленной Министерством социальной политики Украины в июле 2014 г., в стране предусматривается закрытие (или консервация) более 50 шахт (29 шахт - полностью ликвидировать, еще 26 шахт - перевести на «сухую» консервацию). Это повлечет за собой увольнение около 25 тыс. шахтеров к 2017 г.

Приватизация государственных угольных предприятий в Украине позволит значительно сократить расходы госбюджета в виде дотаций угольной отрасли, а затем и полностью отказаться от них, как это сделано в большинстве европейских стран. Часть угольных предприятий в Украине государством переданы в аренду или концессию. По состоянию на конец августа 2013 г., это 49 шахт, доля которых в общей добыче угля составила 71 \% (61 млн т угля).

\section{ТЕРРИТОРИАЛЬНОЕ РАЗВИТИЕ ДОБЫЧИ УГЛЯ В УКРАИНЕ}

В настоящее время уголь в Украине добывают в Донецкой, Луганской, Днепропетровской, Львовской и Волынской областях. На шахтах Донецкой области в 2013 г. добыто 37,5 млн т угля (- 5\% к уровню 2012 г.). По состоянию на начало 2014 г., шахтный фонд Донецкой области состоял из 99 шахт, из них 52 предприятия имели государственную форму собственности. В Луганской области в 2013 г. произведено 26 млн т угля (-3,4\% к уровню 2012 г.), в том числе 5,5 млн т - коксующегося. При этом объем добычи на государственных шахтах Луганской области составил 6,3 млн т, на малых частных шахтах - 0,6 млн т топлива. В Днепропетровской области («Павлоградуголь») в 2013 г. произведено 18,2 млн т угля (+ 1,2\% к уровню 2012 г.), Львовской области - 1,5 млн т (-23,1 \% куровню 2012 г.), Волынской области - 376,5 тыс. т (- 4,1 \% к уровню 2012 г.).

Следует отметить, что в мае 2014 г., несмотря на боевые действия, в Украине было добыто 6,5 млн т угля, что на 8,9\% превышало показатели мая 2013 г. При этом на шахтах в Донецкой области в январе-мае 2014 г. было произведено около 15 млн т рядового угля, в Луганской области - 10,8 млн т, в Днепропетровской - 7,7 млн т, во Львовской - 0,7 млн т, в Волынской - 0,1 млн т. В последующие месяцы 2014 г. работа шахт в Донбассе значительно усложнилась вследствие боевых действий на территории региона. За январь-июль 2014 г. объем добычи угля в Донецкой области составил 20,3 млн т, что меньше аналогичного периода 2013 г. на 6,4\%.

Капитальные вложения в угольную отрасль Украины снизились почти на $50 \%$ и по итогам первого полугодия 2014 г. составили 1,1 млрд гривен, что в действующих ценах на 0,9 млрд гривен меньше, чем год назад. В связи с нехваткой угля в Украине возможно начало добычи бурого угля в Харьковской области. Не исключено возрождение добычи торфа в Украине.

\section{ОСНОВНЫЕ ЧАСТНЫЕ КОМПАНИИ, РАБОТАЮЩИЕ В УГОЛЬНОЙ ОТРАСЛИ УКРАИНЫ}

По состоянию на начало 2013 г., в Украине функционировало 153 угледобывающих предприятия, из которых 47 объектов находились под контролем крупного бизнеса. В настоящее время в Украине работает несколько частных инвесторов, среди которых вертикально интегрированный энергохолдинг «ДТЭК» («DTEK Holdings B.V»), компания «Метинвест», Группа «Донецксталь», Корпорация «Индустриальный Союз Донбасса» и др.
Компания «ДТЭК», входящая в состав финансово-промышленной группы «Систем Кэпитал Менеджмент» (ФПГ СКМ Рината Ахметова, Нидерланды), создана в 2005 г. для стратегического управления предприятиями ФПГСКМ Рината Ахметова. Основными акционерами нидерландской вертикально интегрированной горно-металлургической группы компаний «Metinvest B.V.», материнской компании международной вертикально интегрированной горнометаллургической группы «Метинвест», являются: группа ФПГ СКМ Рината Ахметова (71,25\% акций), «Смарт-холдинг» (23,75\% акций) Вадима Новинского и «Clarendale Limited» (5\% акций) Владимира Бойко.

Следует отметить, что компания «Corum Group», входящая в состав финансово-промышленной группы «Систем Кэпитал Менеджмент» Рината Ахметова, в конце августа 2014 г. запустила в Новокузнецке первую очередь центра по ремонту и обслуживанию техники для горнодобывающей промышленности. Инвестиционный проект в г. Новокузнецке оценивается в 100 млн руб.

Ведущие российские горнометаллургические компании, такие как «Евраз», «Мечел», «Северсталь», «Эстар», также пытались работать на украинском рынке. Однако в 2010г. владелец группы «Эстар» (Вадим Варшавский), который полтора года безуспешно развивал меткомбинат «ИстилУкраина» (ДЭМЗ), свернул свой бизнес. Российский угольнометаллургический холдинг «Мечел» в лице Игоря Зюзина в марте 2013 г. принял решение о ликвидации представительства в Украине и пытался продать принадлежащий ему Донецкий электрометаллургический завод из-за проблем с поставками сырья - металлолома. Компания «Евраз» Романа Абрамовича, которая в 2007 г. приобрела металлургический бизнес группы «Приват», также избавилась от «лишних» активов. Группа в 2012 г. вывела из своей структуры Днепродзержинский коксохимический завод, продав его своей материнской компании «Lanebrook». С начала 2012 г. этот комбинат поставлял кокс «Метинвесту» Рината Ахметова, который вел переговоры о покупке предприятия. И только на фоне других российских инвесторов компания «Северсталь» Алексея Мордашова, которая в 2008г. приобрела у структур Группы Сергея Тигипко завод «Днепрометиз», выпускающий стальную проволоку, гвозди, крепеж.

В 2014 г. в свете последних событий в Донбассе деятельность российских горно-металлургических компаний в Украине будет, скорее всего, прекращена, по крайней мере, если Новороссия не будет проводить самостоятельную экономическую деятельность. В сентябре 2014 г. руководство ДНР потребовало регистрации всех частных шахт и обещает $5 \%$ от оборота в качестве единственного налога. Они намереваются полностью перекрыть вывоз угля в Украину, чтобы накопить перед зимой 4-5 млн т угля для обогрева населения на подконтрольной им территории.

\section{ИМПОРТ КОКСУЮЩЕГОСЯ}

\section{И ЭНЕРГЕТИЧЕСКОГО УГЛЯ В УКРАИНЕ}

Потребность в коксующихся углях в Украине - значительно больше объема добываемого в стране угля, при этом местный уголь содержит высокое содержание серы (около $2 \%)$ и золы. Дефицит коксующихся углей в стране в 2013 г. составил 32,5\%. Поэтому, украинским коксохимическим предприятиям пришлось в 2013 г. импортировать 11,4 млн т коксующихся углей. В целом импорт угля в Украину (с учетом поставок на KX3, а также поставок другим потре- 


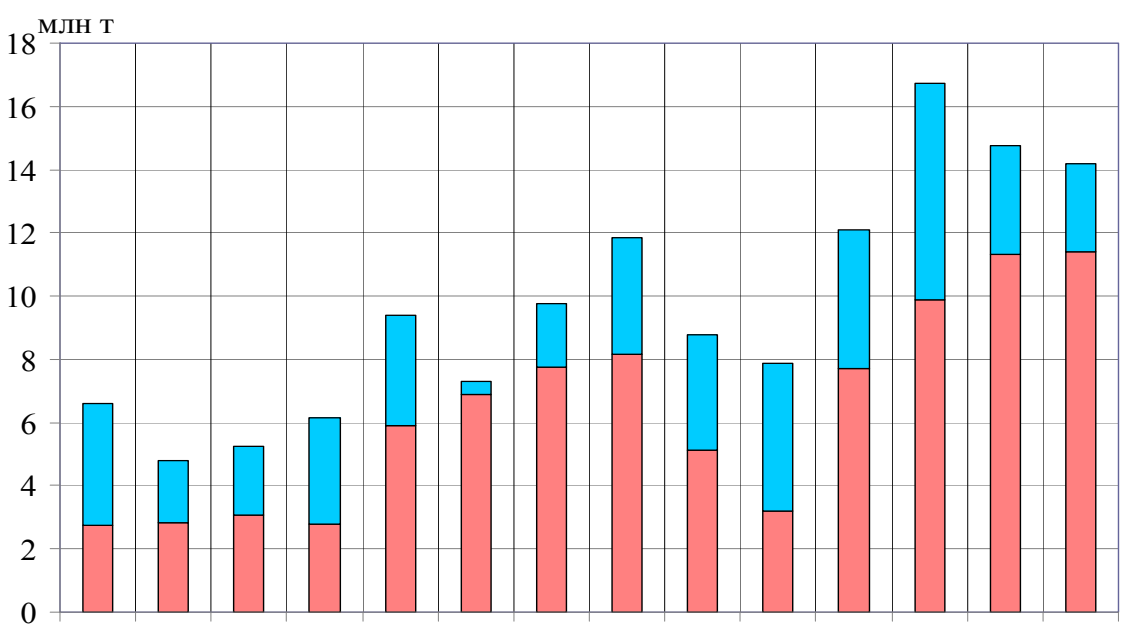

20002001200220032004200520062007200820092010201120122013 $\square$ Коксующиеся угли

$\square$ Энергетические угли

угля в украинском порту. В то же время российский уголь может быть поставлен в порт Украины по цене около 80 дол. США за 1 т. Поэтому если в руководстве Украины возобладают не политические мотивы, а экономические, то не исключены и поставки угля из России, тем более, что Ринат Ахметов, владеющий большинством шахт в Украине, в августе-сентябре 2014 г. сократил свой экспорт угля и начал поставки угля в Украину со своих ростовских предприятий.

В случае, если Украина и Россия не решат вопроса с поставками газа, нехватку угля марок АТ и Т, которые являются основными марками для украинских ТЭС, Правительство Украины собирается компенсировать поставками угля из других стран, в частности из Австралии,

Новой Зеландии, ЮАР, США или Поль-

Pис. 2. Импорт коксующегося и энергетического угля в Украине за 2000-2013 г2.

бителям - цементным и химическим предприятиям) в 2013 г. достиг 14,2 млн т (рис. 2).

Среднегодовые цены на импортный уголь и кокс в 2013 г. снизились по сравнению со среднегодовыми ценами 2012 г., соответственно, на $11 \%$ и $6 \%$ - с 174 и 347 дол. США за т до 155 и 325 дол. США за 1 т. В то же время цены внутреннего рынка в Украине на угольный концентрат марки «К» оказались на уровне 147 дол. США за 1 т. Большая часть коксующегося угля завозилась из России, Казахстана и США. Доля России в общем объеме импортных поставок угля составляла около $70 \%$.

С начала 2014 г. в металлургии Украины наблюдается спад производства, и, соответственно, сократилось и потребление коксующегося угля, и его импорт. Запасы каменного угля у поставщиков и потребителей на начало сентября 2014 г. составляют около 4,6 млн т.

Ресурсов топлива в Украине не хватает. Поэтому, в июне 2014 г. Украина импортировала угля на общую сумму 163,3 млн дол. США. В сентябре 2014 г. Украина подписала с ЮАР соглашение о приобретении 1 млн т угля. Стоимость угля, импортируемого из ЮАР, составляет 91 дол. США за 1 т

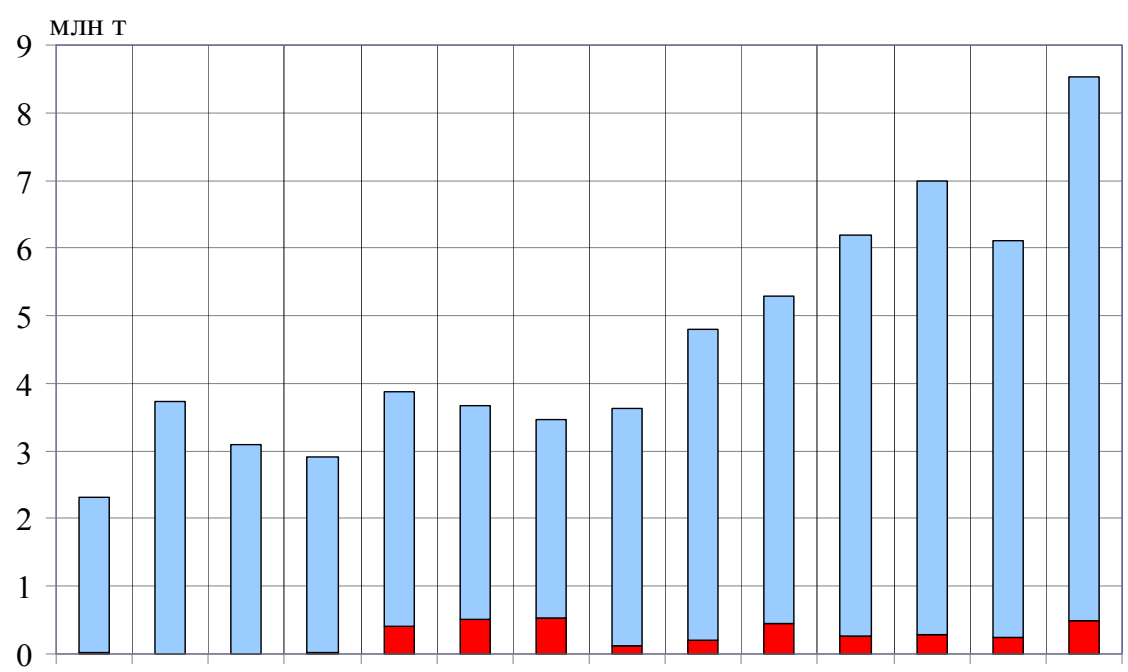

20002001200220032004200520062007200820092010201120122013 $\square$ Коксующиеся угли $\square$ Энергетические угли

Puс. 3. Экспорт коксующегося и энергетического угля в Украине за 2000-2013 г2. ши. По нашим оценкам, при условии отсутствия поставок угля на внутренний рынок из Донбасса потребность в импортном угле оценивается а объеме порядка 5-7 млн т энергетического угля за период сентябрь-декабрь 2014 г., стоимостью до 700 млндол. США.

\section{ПОТРЕБЛЕНИЕ И ЭКСПОРТ УГЛЯ}

\section{В УКРАИНЕ, ВЫРАБОТКА ЭЛЕКТРОЭНЕРГИИ}

Потребление угля в Украине в 2012 г. составляло 61,2 млн т, в т. ч. тепловыми электростанциями - 32,2 млн т, в 2013 г. снизилось на 1,6\% по сравнению суровнем 2012 г., а в июле 2014 г. - сократилось на 11,2\% - до 3.2 тыс. т.

Экспорт украинского угля в последние годы существенно вырос - до 8,5 млн т в 2013 г. Украина поставляла уголь более чем в 50 стран мира. Это в какой-то степени связано с активизацией поставок высокосернистыхукраинскихуглей на Новочеркасскую ГРЭС. Однако с мая 2014 г. компания «ДТЭК», поставлявшая уголь на Новочеркасскую ГРЭС, не стала возобновлять контракта с компанией ОГК-2 и, таким образом, прекратила экспортировать уголь в Россию. В июне 2014 г. Украина экспортировала уголь на общую сумму 67,6 млндол. США. Экспорт коксующегося и энергетического угля в Украине с 2000 по 2013 гг. показан на рис. 3.

В целом в 2014 г. объем экспортируемого украинского угля сократится, как минимум, наполовину.

Угольная генерация в Украине в 2013 г. обеспечивала 47\% производства электроэнергии в стране. В 2013 г. экспорт электроэнергии Украины составил 116 млрд кВт•ч, что на $12 \%$ больше, чем в 2012 г.Украина поставляла электроэнергию, в основном, в Белоруссию, Венгрию и Румынию.Специфика поставокукраинской электроэнергии на экспорт заключается в том, что ее можно поставлять только из Бурштынской ТЭС, принадлежащей Ринату Ахметову, который, таким образом, является фактическим монополистом ее экспорта. В связи с этим, Кабинет министров Украины в августе 2014 г. 
ввел чрезвычайное положение на рынке электроэнергии. Теперь загрузка энергоблоков будет производиться не по действующим нормативам, а исходя из наличия топлива. Если перебои с углем сохранятся, атомной генерации придется замещать угольную генерацию.

В 2014 г. в Украине ожидается снижение потребления электроэнергии, как минимум, на 10 млрд кВт/ч - до 171 млрд кВт/ч, неминуемы веерные отключения электроэнергии в промышленных и даже социальных объектах в регионах страны. Экспорт электроэнергии, скорее всего, будет прекращен, так как Украине самой не хватит ее собственного вырабатываемого объема электроэнергии.

Основа энергетики Украины - атомные электростанции и крупные угольные ТЭЦ. В последние годы на ТЭЦ производилось до 53 \% генерации. С начала июля 2014 г. была сокращена подача газа на объекты «Киевэнерго» и харьковскую ТЭЦ. Из-за боевых действий в Донбассе и частого отключения Луганской ТЭЦ большая нагрузка легла на оставшуюся энергосистему. Минэнерго Украины ищет выхода в наращивании выработки электроэнергии на АЭС, но здесь возникает проблема ночного минимума. Украинские АЭС работают на максимальных объемах мощности, и наращивание выработки приведет к тому, что очень сложно будет регулировать неравномерность потребления. Придется ночью останавливать все угольные блоки, а днем их запускать. Это очень дорогостоящий процесс и приведет к быстрой изнашиваемости угольных блоков. Кроме того, имеются сетевые ограничения, которые делают наращивание выработки АЭС бессмысленными.

\section{ПРОИЗВОДСТВО, ЭКСПОРТ И ИМПОРТ КОКСА, ЦЕНЫ НА КОКС И КОКСУЮЩИЙСЯ УГОЛЬ}

В 2013 г. в Украине произведено 17,6 млн т кокса, что на 7,1 \% меньше уровня 2012 г. Потребление кокса в 2013 г. сократилось на 2,8\%. Однако производство чугуна возросло на 2\%, что стало возможным благодаря внедрению в доменном производстве новых установок вдувания пылеугольного топлива. В 2014 г. планировалось ввести в действие данную технологию на Енакиевском МЗ и ДМК им. Дзержинского, но в связи с военными действиями в Восточной Украине и нехваткой средств это может быть отложено.

В августе 2014 г., согласно данным отраслевого объединения предприятий «Металлургпром», производство валового кокса 6\%-ной влажности в Украине снизилось до 723 тыс. т (- 44,5\% по сравнению с июлем 2014 г.), что вызвано продолжающейся войной на Востоке Украины, где сосредоточены основные коксохимические мощности и заводы. Поэтому в августе 2014 г. добыча коксующегося угля упала втрое - до 250 тыс. т, импорт коксующегося угля сократился вдвое - до 460 тыс. т. Совокупное производство кокса в январе-августе 2014 г. в Украине уменьшилось на 11,1\% - до 10,6 млн т.

Чтобы компенсировать падение производства кокса в своей стране, Украина в 2013 г. импортировала 702 тыс. т кокса и полукокса (на 40,2\% больше, чем в 2012 г.). В денежном выражении импорт кокса возрос на 30,3\% - до 190,3 млндол. США.

За период январь-август 2014 г. импорт кокса Украиной, по данным Министерства доходов и сборов Украины, возрос на 9,7\% по сравнению с аналогичным периодом 2013 г. - до 519,9 тыс. т, однако снизился на 13,6\% - в денежном выражении - было ввезено кокса на сумму
117,3 млндол. США. Фактически единственным поставщиком данного продукта осталась Польша.

От кокса из России и Казахстана украинские металлурги в первом полугодии 2014 г. отказались. В настоящее время «Arcelor Mittal Кривой Рог» - единственная компания, которая не может обойтись без импортного кокса. Но в то же время говорить о почти полной коксовой независимости Украины от импортного кокса не совсем корректно, так как почти половину потребляемых коксующихся углей она ввозит из-за рубежа, из которых $70 \%$ ранее имели российское происхождение.

В 2014 г. ожидается снижение по сравнению с уровнем 2013 г. мировых цен на импортный коксующийся уголь и кокс, соответственно, на $6 \%$ и $7 \%$ - с 143 и 269 дол. США за 1 т до 135 и 250 дол. США за 1 т.

Потребность украинских сталеваров в коксе в настоящее время - около 14 млн т, в то время как в 2000 г. была более 20 млн т. Кокс понемногу возвращает себе статус продукта сугубо внутреннего потребления. Одной из причин такой перемены является ценовая конъюнктура и ситуация, сложившаяся в стране в связи с боевыми действиями в Донбассе. В последние годы цены на кокс и коксующийся уголь, как на мировом рынке, так и на украинском, - снижаются.

Экспортные поставки кокса и полукокса в 2013 г. составили около 2 млн т (405 млн дол. США), при средней цене около 200 дол. США за 1 т. В период с января по август 2014 г., по данным Министерства доходов и сборов Украины, на экспорт было поставлено около 1,1 млн т кокса и полукокса (-27,9\% по сравнению с аналогичным периодом 2013 г.) на общую сумму 171,8 млн дол. США. Основной объем экспорта кокса осуществлялся в Индию $(38,25 \%$ поставок в денежном выражении), Алжир (9,27\%) и Россию (8,75\%). Среди основных экспортеров - промышленнофинансовая группа «Донецкталь», в которую входят ЧАО «Донецксталь-метзавод», ПАО «Донецкий металлургический завод», АО «Ясиноватский коксохимический завод», АО «Макеевский коксохимический завод», АО «Ш/у Покровское». Однако в результате постоянных артиллеристских обстрелов в Донбассе к августу 2014 г. были остановлены все коксохимический заводы.

UDC 622.33(477) "2000/2014" (C L.S. Plakitkina, 2014 ISSN 0041-5790 • UGOL №11-2014/1064/

\section{Title}

UKRAINE'S COAL MINING INDUSTRY IN THE PERIOD OF 2000-2014 YEARS

\section{Author}

Plakitkina L.S.

\section{Authors' Information}

Plakitkina L.S., chief of laboratory "Scientific foundations for the development and management of coal and peat industry" Institute for Energy Studies of RAS, Moscow, Russia, e-mail: luplak@rambler.ru

\section{Abstract}

The article presents the analysis of mining, export and import of coking and thermal coal in Ukraine in the period from 2000 to 2013 and from January to August 2014; considered the territorial development of coal mining enterprises in Ukraine; the main private companies working in the Ukrainian coal industry are identified. The power generation and consumption in Ukraine, coke production, export and import, the price for charred coal and coking coal are analyzed as well.

\section{Keywords}

Coal Mining, Coal Export, Coal Import, Coal Consumption, Power Generation, Coke Production, Prices for Coke, Prices for Crozzling Coal. 


\section{Зарубежная панорама}

\section{МИРОВОЙ УГОЛЬНЫЙ РЫНОК ЖДЕТ СПАД ПОСЛЕ ПИКА ПОТРЕБЛЕНИЯ В КНР, КОТОРЫЙ БУДЕТ ЗАФИКСИРОВАН В БЛИЖАЙШИЕ ГОДЫ}

Совместное исследование ASrIA и Carbon Tracker Initiative предупреждает: мировой угольный рынок ждет спад после пика потребления в КНР, который будет зафиксирован в ближайшие годы. На данный момент Китай — крупнейший в мире добытчик и потребитель угля, который обеспечивает почти половину всего мирового рынка. Но он становится все ближе к точке самых радикальных изменений.

Сегодня энергетический уголь (недорогой сорт угля для работы ТЭС) обеспечивает уже менее $80 \%$ энергии, вырабатываемой в Китае. По прогнозам аналитиков, пика потребления угля Китай достигнет в период с 2015 по 2030 г. После этого потенциально не востребованными окажутся до $40 \%$ генерирующих мощностей на основе угля.

Спад произойдет по причине замедления роста ВВП и снижения энергоемкости производств; также окажут влияние нехватка питьевой воды; выплаты за выбросы углерода в атмосферу; стратегические меры реагирования на проблему загрязнения воздуха и значительный рост технологий получения электрической энергии из возобновляемых источников. Перечисленные факторы снижают привлекательность угля как топлива.

По объему генерируемой при помощи ветра электроэнергии Китай уже сейчас в мире занимает второе место. При этом довести до $15 \%$ долю ВИЭ в общем производстве - задача, поставленная в текущей пятилетке.

\section{В ИНДОНЕЗИИ ВЫРОСЛА ДОБЫЧА УГЛЯ}

Объемы добычи угля в Индонезии в январе-марте 2014 г. увеличились на 110 млн т. Об этом сообщает Reuters. По итогам I кв. 2013 г. производство продукции в стране оценивалось на уровне 105 млн т. В целом в нынешнем году Индонезия рассчитывает выпустить 421 млн т угля.

В феврале 2014 г. по сравнению с январем Индонезия сократила затраты на импорт стали на 14,56\%. В частности, затраты на поставки металла в страну составили в указанный период 646,9 млн дол. США. Напомним, что Индонезия в 2013 г. по сравнению с 2012 г. сократила затраты на импорт стальной продукции на 5,77\%. В частности, затраты на поставки металла составили в указанный период 9,55 млрддол. США.

Тем временем правительство Индонезии принимает меры по ограничению производства угля до 400 млн. т с целью прекратить падение цен на него. В частности, чиновники обращались с просьбой не превышать производственные планы к добывающим компаниям. Тем не менее, по данным Morgan Stanley, в 2014 г. предложение по энергетическому углю превысит спрос на 4,9 млн т.

В настоящее время существует угроза, что компания Berau Coal Energy (BRAU) закроет один из своих крупнейших рудников в Индонезии. Glencore Xstrata Plс и BHP Billiton Ltd., вероятнее всего, будут вынуждены приостановить или отложить реализацию планов по наращиванию угольных мощностей на территории Австралии. Отметим, что, по данным global COAL, 28 марта 2014 г. цена на уголь в австралийском Ньюкасле составила 74,01 дол. США, что на $13 \%$ меньше, чем в начале 2014 г.

\author{
ОТ РЕДАКЦИИ \\ Вниманию читателей \\ предлагается \\ публикация из материалов \\ "Зарубежные новости» - \\ 6ыn. № 231 - 232.
}

\section{ОТ ЗАО «РОСИНФОРМУГОЛЬ»}

\section{Зарубежные новости}

\section{http: //www.rosugol.ru}

Более полная и оперативная информация по различным вопросам состояния и перспектив развития мировой угольной промышленности, а также по международному сотрудничеству в отрасли представлена в выпусках «Зарубежные новости», подготовленных 3 АО «Росинформуголь» и выходящих ежемесячно на отраслевом портале «Российский уголь» (www.rosugol.ru).

Информационные обзоры новостей в мировой угольной отрасли выходят периодически, не реже одного раза в месяц. Подписка производится через электронную систему заказа услуг.

По желанию пользователя возможно получение выпусков по электронной почте.

По интересующим вас вопросам

обращаться по тел.: +7(495) 723-75-25,

e-mail: market@rosugol.ru -

отдел маркетинга и реализации услуг.

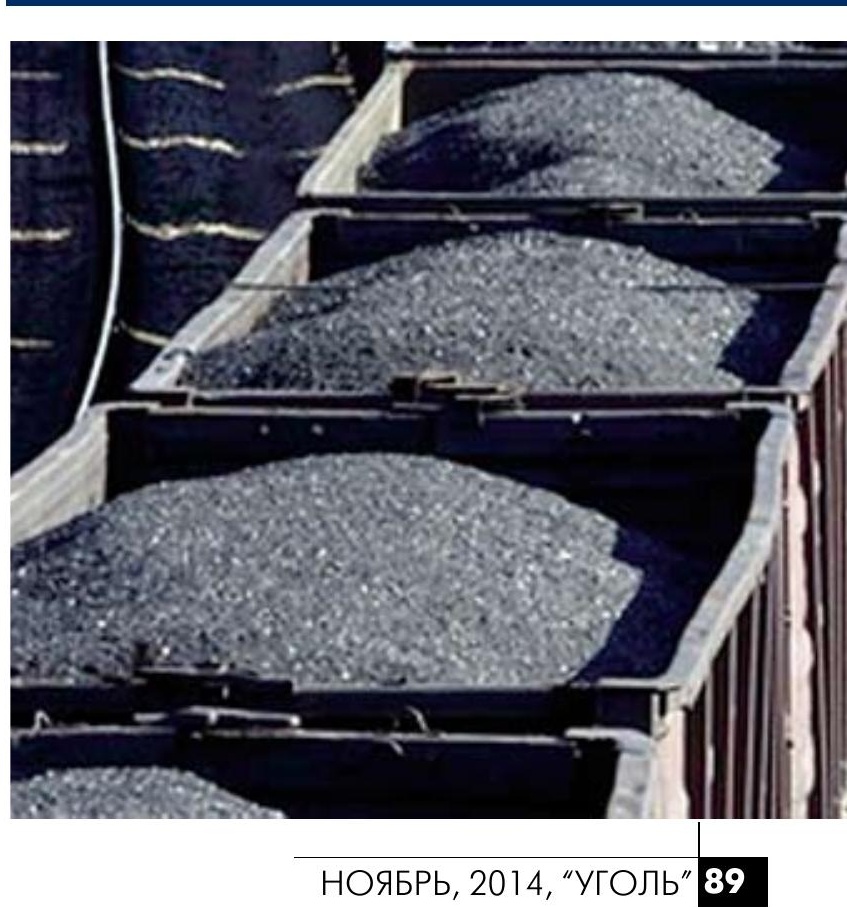




\section{В УКРАИНЕ СТАЛИ МЕНЬШЕ ИСПОЛЬЗОВАТЬ ГАЗА И БОЛЬШЕ УГЛЯ}

На Украине объемы использования природного газа в мае 2014 г. по сравнению с аналогичным месяцем прошлого года сократились на 16,5\% и составили 1 млрд 783,8 млн куб. м, сообщает Государственная служба статистики. При этом по сравнению с апрелем 2014 г. объемы использования природного газа на Украине сократились на 39,1\%.

Объемы использования каменного угля в мае 2014 г. выросли по сравнению с аналогичным месяцем 2013 г. на 3,9\% и составили 5 млн 256 тыс. т. По сравнению с апрелем 2014 г. объемы использования каменного угля увеличились на 2,7\%.

Кроме того, объемы использования сырой нефти, включая конденсат, сократились на 3,7\% в годовом исчислении и увеличились на 18,6\% в месячном исчислении, составив 271 тыс. т.

Бензина моторного в мае 2014 г. было использовано на 15,1\% меньше, чем за аналогичный период 2013 г., и на 0,4\% меньше, чем в апреле 2014 г. - 56,4 тыс. т. Из этого количества населению было продано

\section{КИТАЙ ЗАПЛАНИРОВАЛ В 2014 Г. СМОНТИРОВАТЬ 10 ГВТ СОЛНЕЧНЫХ БАТАРЕЙ}

Национальное управление энергетики Китая установило плановый показатель 10 ГВт общей мощности фотоэлектрических солнечных систем, которые должны быть смонтированы в Китае в 2014 г. Управление сообщило, что $60 \%$ запланированных мощностей отведено под распределенные фотоэлектрические системы и $40 \%$ - под фотоэлектрические генерирующие станции.

Отраслевые источники из Тайваня указывают, что запланированные объемы значительно ниже ранее прогнозированных экспертами рынка 12-14 ГВт, вероятно, это вызвано тем, что китайское правительство посчитало, что слишком высоки финансовое бремя и вероятность того, что чрезмерно высокие планы могут привести к перенасыщению рынка фотоэлектрической продукции.

«Сейчас китайское правительство предлагает льготные тарифные ставки 0,42 юаня/кВт (0,07 долл. /кВт) для распределенных фотоэлектрических систем, установленных преимущественно на крышах, и 0,9-1 юань/кВт для фотоэлектрических генерирующих станций», - сообщают источники. через АЗС бензина моторного 212,7 тыс. т, газойлей (дизельного топлива) - 142,8 тыс. т. Использование газойлей (топливо дизельное) в апреле 2014 г. уменьшилось на $11,2 \%$ в годовом исчислении и на 5,1\% в месячном исчислении, составив 287,8 тыс. т.

Объемы использования топочных тяжелых мазутов сократились на 45,7\% против мая 2013 г. и составили 6,9 тыс. т, в сравнении с апрелем 2014 г. - сократились на $42 \%$. При этом, по оценке Госстата, использование в АРК и городе Севастополе составляло: угля каменного - 12,5 тыс. т; сырой нефти, включая газовый конденсат, - 0,1 тыс. т; природного газа - 56,1 млн куб. м; бензина моторного - 2,6 тыс. т; газойля (дизельного топлива) - 6,1 тыс. т; топочных мазутов тяжелых 0,2 тыс. т.

\section{ПАДЕНИЕ ОБЪЕМОВ ДОБЫЧИ УГЛЯ В КОЛУМБИИ}

Национальное агентство горнодобывающей промышленности Колумбии (ANM) объявило о падении добычи угля на территории страны до 85,5 млн т, что на 4,15\% меньше, чем в 2012 г. Падение объемов связано в первую очередь с непрекращающимися забастовками, запретительными мерами по экспорту и логистическими сбоями на протяжении всего прошлого года.

B ANM заявили, что Колумбия выполнила только 84,2 \% запланированного объема добычи угля в 2013 г. 94,3 \% всего полученного угля было отгружено на экспорт. Оставшиеся 4,9 млн т были использованы внутри страны на получение электроэнергии, обеспечение металлургических и цементных заводов.

Тем не менее добыча угля в Колумбии постепенно набирает обороты. Хотя общий объем в 2013 г. был ниже, чем в 2012, только за четвертый квартал прошлого года производство угля подскочило на 18 ,\% до 3 млн 800 тыс. т. Сегодня Колумбия продолжает оставаться на 4-м месте в мировом рейтинге стран-кспортеров угля.

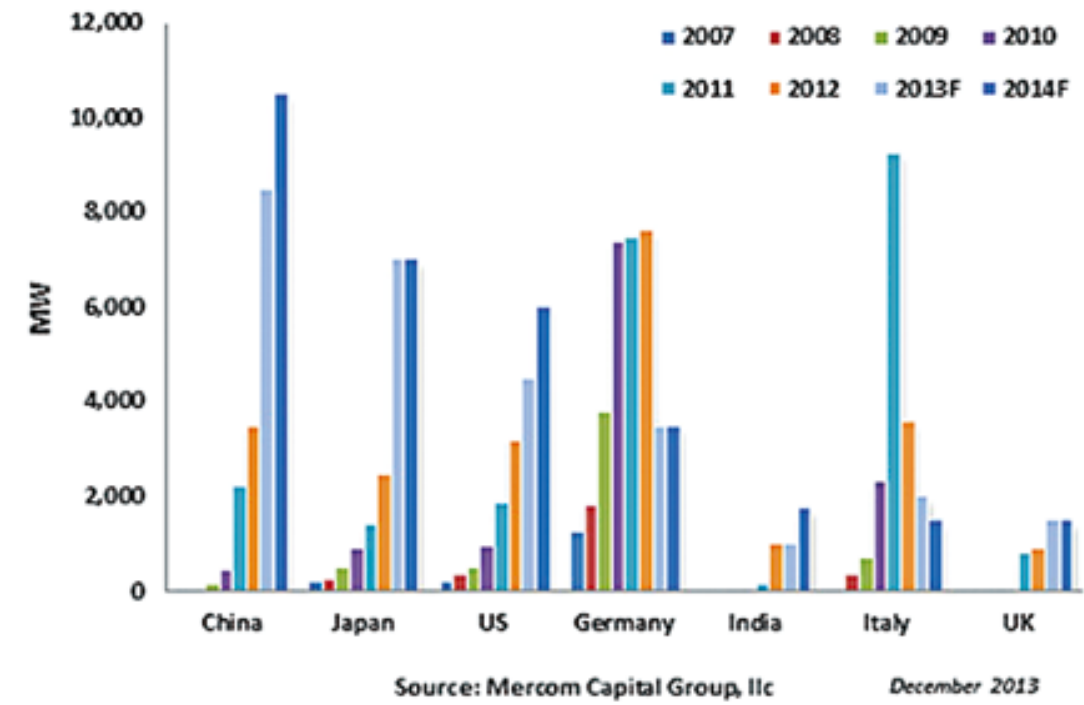

Прогноз спроса на солнечные батареи по странам, MBm. По данным Mercom Capital Group, декабрь 20132. 


\section{МОНГОЛИЯ БЕРЕТ КУРС}

\section{НА ЭКСПОРТ ВОЗОБНОВЛЯЕМОЙ ЭНЕРГИИ}

Не углем единым богата «бедная Монголия». На сегодняшний день, опираясь на собственные ресурсы, она может построить источники производства электроэнергии мощностью в 240 ГВт за счет угля, 4300 ГВт за счет ветра, 2000 ГВт - солнца, 6200 ГВт - природного газа. По мере роста ее внутренней экономики страна Чингисхана будет готова продавать экологичную энергию не только соседям.

Мировая экономика достигла сегодня предела своего развития на основе использования углеводородной энергии как основного источника. Затянувшийся экономический кризис характеризуется исчерпанием возможностей существующей глобальной энергетики, а также глубокими переменами, вызванными появлением новых технологий, изменений спроса на энергопродукцию и экономической неопределенностью. Эти вызовы диктуют необходимость новой эффективной и стабильной модели экономической системы.

Обсуждение концепции «зеленой» экономики в последнее время занимает центральное место в политических дебатах. Этот вопрос широко рассматривается на многих важных международндых форумах, включая ООН, Большую восьмерку, БРИКС, АТЭС и другие. Рост популярности концепции «зеленой экономики» во многом вызван многочисленными кризисами, с которыми столкнулся мир в последние годы, прежде всего климатическим, экологическим, продовольственным, финансовым и экономическим.

Монголия производит 90 \% процентов электроэнергии из угля, что способствует выделению парникового газа в значительном объеме. В связи с этим, страна придает

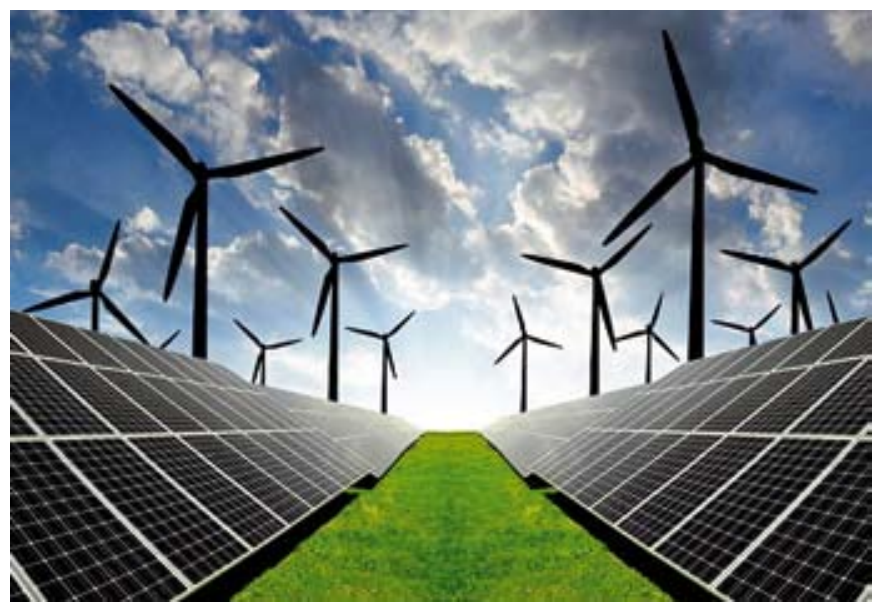

особое значение зеленому развитию на основе использования возобновляемых источников энергии. В настоящее время 5-7\% всего потребления в электроэнергии производится за счет использования возобновляемых источников энергии.

В регион Северо-Восточной Азии входят такие страны, как РФ, Монголия, КНР, КНДР, Республика Корея и Япония. При этом Республика Корея и Япония являются крупнейшими импортерами электроэнергии. Но наряду с этим Северо-Восточная Азия остается крупнейшим производителем и экспортером. Регион производит одну треть мировой энергии. В дальнейшем вслед за стремительным экономическим ростом региона также стремительно будет расти спрос на электорэнергию. Монголии с ее обширными ресурсами возобновляемой энергии открываются широчайшие возможности развития этой отрасли и дальнейшего экспорта электроэнергии. Нужны лишь существенные капиталовложения.

\section{НЕКРОЛОГ}

\section{БУТКИН Владимир Дмитриевич (27.04.1928 - 14.10.2014)}

14 октября 2014 г. после продолжительной болезни скончался Заслуженный деятель науки РФ, член-корреспондент Академии технологических наук, почетный член Академии горных наук, Почетный работник высшего профессионального образования РФ, доктор техн. наук, профессор кафедры «Горные машины и комплексы» Государственного университета цветных металлов и золота (ныне Сибирский федеральный университет) Владимир Дмитриевич Буткин.

После окончания в 1950 г. Электромеханического факультета Московского горного института Владимир Дмитриевич был направлен в Германию, где работал главным ин-

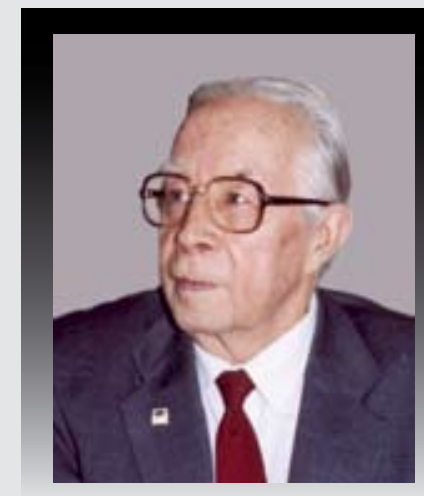
женером и директором уранодобывающих горных предприятий до 1955 г.

В дальнейшем, работая в НИИОГР (г. Челябинск), он защитил кандидатскую и докторскую диссертации по направлению повышения эффективности техники и технологии бурения взрывных скважин. В 1981 г. Владимир Дмитриевич явился одним из инициаторов создания и стал первым директором Научно-исследовательского и проектно-конструкторского института по проблемам развития Канско-Ачинского угольного бассейна (КАТЭКНИИуголь). С 1981 г. В.Д. Буткин работал в Государственном университете цветных металлов и золота.

Профессор Владимир Дмитриевич Буткин является автором белее 300 научных работ, в том числе 20 монографий и учебных пособий, имеет 110 авторских свидетельств на изобретения. Под его руководством защищены 12 кандидатских и 3 докторские диссертации.

Память о Владимире Дмитриевиче Буткине будет храниться долгие годы в сердиах сотрудников и выпускников Сибирского федерального университета, а также работников горнодобывающих предприятий России. 


\section{ЕВРОПЕ ГРОЗИТ ЭНЕРГЕТИЧЕСКИЙ КРИЗИС}

Страны-члены Евросоюза стоят на грани энергетического кризиса в связи с недостатком природных ресурсов. Больше всего опасности подвержены Великобритания, Италия и Франция. Природные ресурсы Европы подходят к своим нулевым значениям. Уголь, нефть и газ просто заканчиваются, говорится в докладе британского Института глобального устойчивого развития (Global Sustainability Institute). Данный прогноз ставит под большое сомнение планы европейских политиков по снижению зависимости от поставок энергоресурсов из России.

Так, в Великобритании через три года исчезнут собственные запасы природного газа, через четыре споловиной года иссякнет уголь, а через пять лет - и нефть. Во Франции ситуация в сфере энергоресурсов еще хуже: менее чем через год она исчерпает все три вида полезных ископаемых.

Доклад нарисовал пеструюудручающую картину по всей Европе. Относительно неплохо дело обстоит с углем. Так, Болгария имеет 34-летний запас угля, Германия - 250летний запас угля, однако менее чем через год ей совсем неоткуда будет добывать нефть.

«Уголь, нефть и газ в Европе заканчиваются, и она нуждается в альтернативных источниках», - подчеркивается в исследовании, передает ВВС. Сам доклад еще не опубликован. Между тем некоторые эксперты скептически относятся к такого рода прогнозам. Так, Джим Скеа, консультант-исследователь Энергетической стратегии Великобритании, ставит под сомнения выводы института. «Это звучит маловероятно. Более того, это не имеет значения - Великобритания имеет стабильные поставки импортной энергии», - говорит он. Однако статистические данные последних десятилетий подтверждают, на первый взгляд, кажущийся апокалиптическим прогноз института GSI.

Уголь в Европе в целом еще имеется. Другое дело, что угля, который залегает неглубоко (открытый способ добычи),

\section{ЕВРОСОЮЗ ИЩЕТ СПОСОБЫ СОКРАТИТЬ ЗАВИСИМОСТЬ ОТ РОССИЙСКОГО ГАЗА}

Геополитические соображения наряду с растущими ценами на газ вынуждают Евросоюз переходить на уголь, относительно дешевый энергоноситель. И даже Германия, известная своей приверженностью альтернативным источникам энергии, не оказалась исключением.

Сейчас треть газа, потребляемого Европой, поступает из России. Геополитические соображения наряду с растущими ценами на газ вынуждают Евросоюз переходить на уголь, относительно дешевый энергоноситель. Потребление угля в ЕС уверенно растет, передает Russia Today.

Германия занимает второе место в мире по запасам бурого угля. Те, кто работают с этим ресурсом, с недоверием относятся к позиции государства о том, что бу-

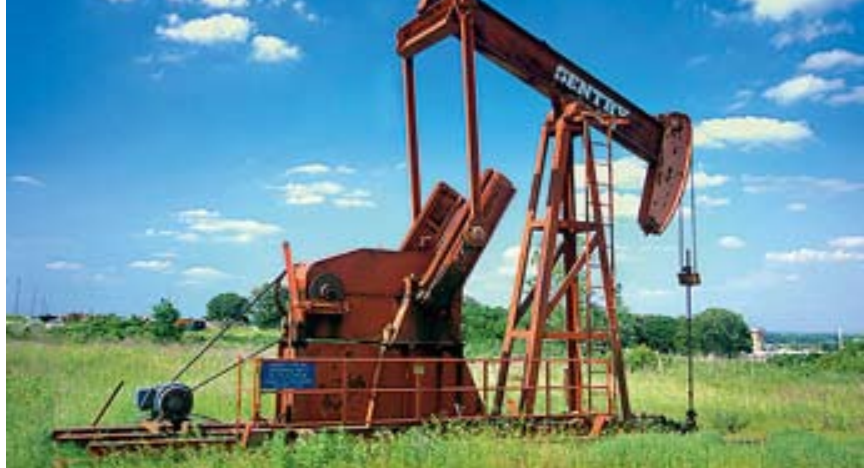

остается уже немного, а себестоимость подземной добычи каменного угля экономически не выгодна - слишком дорогой становится энергия. Великобритания, Чехия и Испания в последние годы постоянно заявляют о планах закрыть ряд шахт.

В Польше и Германии - традиционных добытчикахугля в Европе - аналогичная ситуация. Польша в 1980-х годах вообще стала четвертой страной в мире по добыче угля, уступив только Китаю, СССР и США. Однако с того момента добыча угля в Польше неуклонно сокращалась. Сейчас в Польше отмечается сокращение добычи каменного угля при некотором росте доли бурого угля в энергобалансе. Потому что при пересчете на полученный киловатт-час бурый уголь использовать на 35-40\% выгодней, чем каменный.

Германия хотела к 2018 г. прекратить любую угледобычу. По каменному углю так и произойдет - его добычу остановят к этому сроку. Но вот производство бурого угля будет продолжаться, но только благодаря общественным протестам против закрытия одного из крупнейших буроугольных месторождений в Германии, принадлежащего компании RWE. Сама компания хотела закрыть и эту добычу из-за низкой прибыли.

\section{СЛАБАЯ РУПИЯ СНИЗИЛА ИНДИЙСКИЙ ИМПОРТ УГЛЯ НА $33 \%$}

Как сообщает агентство Reuters, слабый курс индийской рупии сократил импорт угля в январе 2014 г. на 33 \% по сравнению с прошлым годом. Проблемы внутреннего рынка угля в Индии привели к тому, что страна стала одним из трех крупнейших импортеров угля, после Китая и Японии. Импортные поставки в январе составили 9,2 млн т против 13.6 млн т в прошлом году и 13,1 млн т в декабре 2013 г. По словам директора исследовательской компании OreTeam Prakash uri - «падение импорта мы объясняем лишь снижением курса рупии». Большинство индийских экспортеров угля - из Индонезии, ЮАР, Австралии и Канады. дущее энергетики - исключительно возобновляемые источники. «Канцлер Меркель - доктор физических наук. Я уверен, что она понимает: нарушить законы физики невозможно. Если мы хотим использовать энергию в необходимых нам объемах, нам нужен уголь. И не только сейчас, но и в ближайшие 20-30 лет», - заявил Юрген Акерманн, руководитель производства Vattenfall.

Несмотря на лобби зеленых, которые продвигают использование энергии ветра и солнца в стране, по всей видимости, сейчас единственный надежный энергоноситель для Германии - это уголь. 


\section{Лучшие бойцы трудовых отрядов СУЭК встретились с руководством компании}

\begin{abstract}
26 сентября 2014 г. в головном офисе ОАО «СУЭК» состоялась встреча лучших участников трудовых отрядов СУЭК с генеральным директором ОАО «СУЭК» Владимиром Рашевским.
\end{abstract}

В этом году трудовые отряды СУЭК в Красноярском крае объединили более 400 подростков, в Кузбассе - более 200 школьников. Лучшие из них были награждены поездкой в Москву. Три дня 14 бойцов трудовых отрядов из Красноярского края и Кемеровской области в возрасте 14-16 лет знакомились с самыми интересными местами столицы, а также посетили головной офис СУЭК и встретились с генеральным директором компании.

На встрече ребята, прежде всего, рассказали о сделанном за прошедший летний сезон. По их словам, каждый трудовой сезон выдается по-своему насыщенным, в этом году много внимания было уделено благоустройству территорий и социальной адресной помощи пенсионерам в рамках акций «10 добрых дел» и «Твори добро».

Так, например, Ирина из с. Камала Рыбинского района Красноярского края рассказала: «Свою деятельность в этом году мы начали еще в феврале - марте, когда лежал снег. Первое, что мы сделали, - расчистили от сугробов детскую площадку. Летом у нас начались другие добрые дела. В нашем селе есть дом престарелых, в котором мы выступили створческим концертом. Пели песни, читали стихи. Выбрали военную тематику, так как там много ветеранов, которые пережили войну, и им это было интересно. Было видно, что люди очень и очень нам благодарны. У них даже слезы были на глазах, что, в свою очередь, и у нас вызвало массу эмоций. Потом обустраивали палисадник около сельской администрации, дороги очищали от мусора. Но большую часть времени в этом сезоне мы уделили пожилым людям. Кому-то уголь набрать, кому-то грядки вскопать, кому-то по дому помочь. Еще памятник погибшим в войне облагородили, покрасили его, убрали рядом, сделали скамейки. Хотелось сделать так, чтобы людям нравилось, так как мы знаем, что на 9 Мая там всегда проходит праздник».

Заместитель исполнительного директора по связям и коммуникациям ОАО «СУЭК-Красноярск» Марина Смирнова отметила некоторые результаты: «За последние два года красноярские трудотряды благоустроили территорию площадью 7 млн кв. м, собрали мусора 1490 m, посадили 250 деревьев и 5 тыс. цветов. Покрасили, отремонтировали, заменили старые на новые более 7 км заборов, вкопали $200 \mathrm{cmолбов.} \mathrm{Иэто} \mathrm{только} \mathrm{по} \mathrm{благоустройству.}$ Время показывает, что проект актуален и востребован. Он не просто существует, он набирает обороты, каждый год появляются новые направления. Сейчас это уже полноченное молодежное движение».

Внимательно выслушав рассказы трудотрядовцев, Владимир Рашевский отметил, что их деятельность не только приносит реальную пользу, но и является отличным примером для подражания: «Ваш пример заставляет всехостальных задуматься: «А я-то где? А я почему не в фирмен-
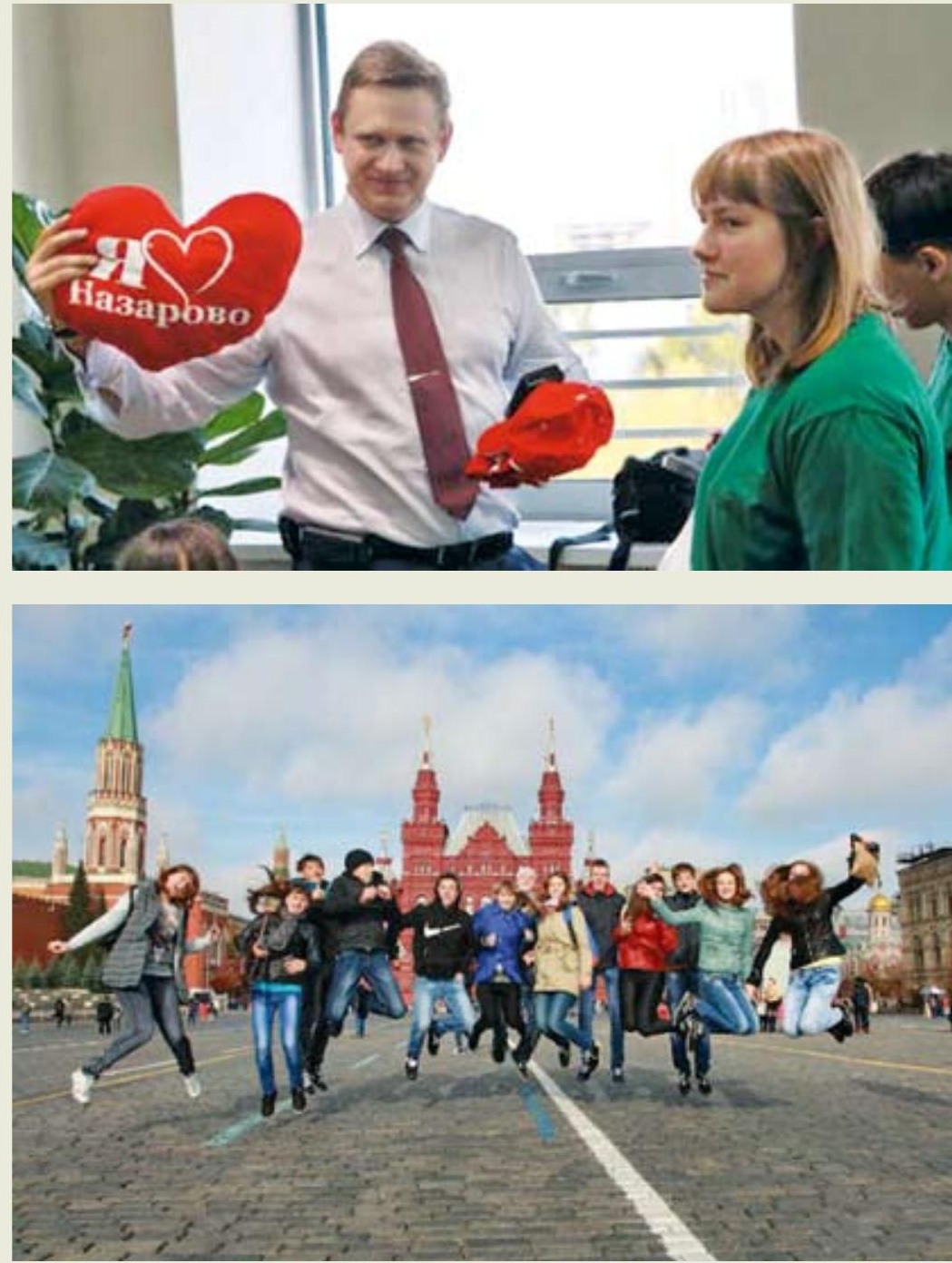

ной трудотрядовской майке? Почему я не стараюсь создать что-то такое, о чем мне завтра будет приятно рассказать своим близким, друзьям?» Мы вами по-настоящему очень гордимся. Хотелось бы, чтобы вы продолжали свою созидательнуюработу, чтобы вы выросли настоящими людьми сбольшой буквы, обязательно во всем состоялись, чтобы кто-то из вас пришелзавтра наработув СУЭК, подхватил тодело, которое делаем мы. И, главное, чтобы вы все были патриотами нашей страны, строили, созидали, создавали!»

\section{Наша справка}

Проект «Трудовые отряды СУЭК» проводится в рамках соглашений о партнерстве между Фондом «СУЭК-РЕГИОНАМ», местными региональными администрациями, молодежными биржами труда и иентрами занятости населения. СУЭК обеспечивает на время летних каникул занятость и финансирование труда старшеклассников, которые активно участвуют в благоустройстве своей малой родины. Проект реализуется в Красноярском крае с 2005 г., в 2013 г. отряды СУЭК начали работу в Кузбассе, Бурятии, Приморском и Хабаровском краях. 


\section{Ваша проблема нам известна! Узнайте решение на странице 68}

Программное обеспечение для обслуживания углеобогатительных фабрик

\section{Coral Suite}

\section{Решает задачи}

- Поиск причины простоя

- Обоснование предварительных заказов запчастей

- Взаимодействие служб фабрики

- Поиск документации на оборудование

- Предоставление информации о поставке запчастей

\section{Уникальность}

- Специализация на углеобогащении

- Применение передовых технологий

- Является воплощением огромного опыта разработчика автоматизации процессов углеобогатительных фабрик 